BAKSA-HASKÓ GABRIELLA

\title{
INFORMATIKAOKTATÁS A GAZDÁLKODÁSTANI FELSŐOKTATÁSBAN
}


Számítástudományi Tanszék

Témavezető: Dr. Dobos Imre

(C) Baksa-Haskó Gabriella 
Budapesti Corvinus Egyetem

Gazdálkodástani Doktori Iskola

\section{Informatikaoktatás a gazdálkodástani felsőoktatásban \\ Ph.D. értekezés \\ írta: \\ Baksa-Haskó Gabriella}

Budapest, 2014 
DOI: $10.14267 /$ phd.2014081 


\section{TARTALOMJEGYZÉK}

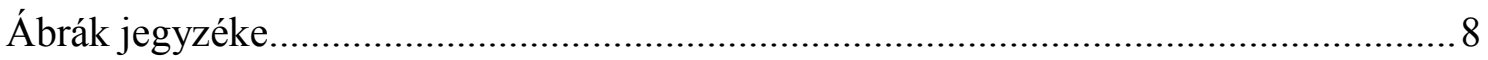

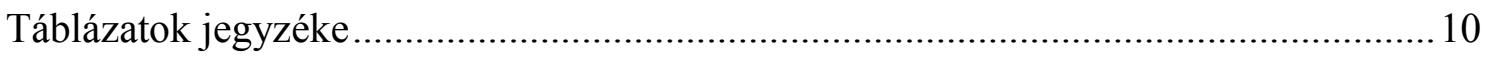

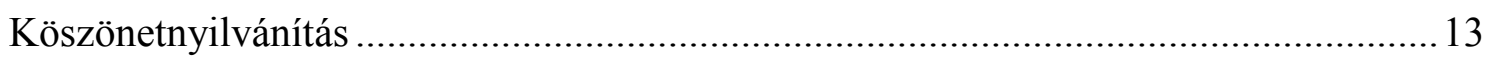

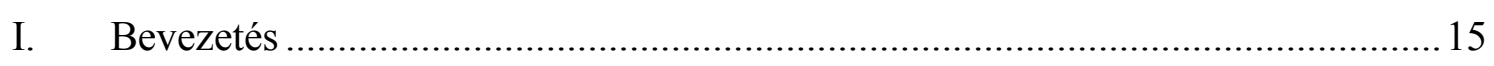

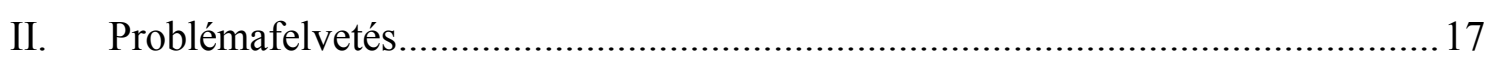

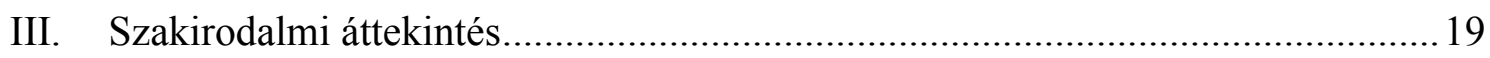

III.1. Pedagógiai elméletek, tananyagfejlesztés ............................................... 19

III.1.1. Kinek a feladata a tantervkészítés? ............................................. 19

III.1.2. Bloom taxonómiája ................................................................ 20

III.1.3. A tanulási eredmények evolúciója ..............................................23

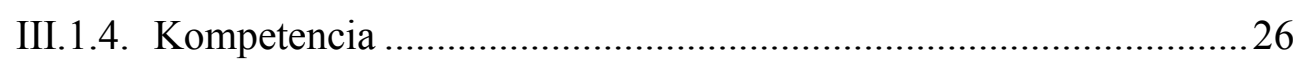

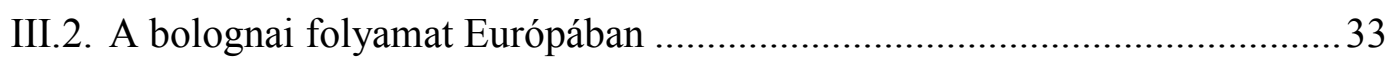

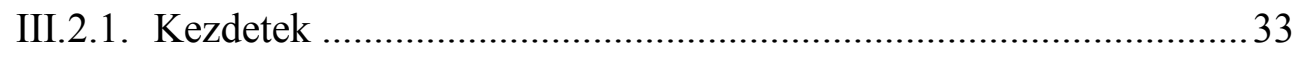

III.2.2. Megalakul az Európai Felsőoktatási Térség ................................. 36

III.2.3. Tuning projekt........................................................................ 36

III.2.4. A bolognai folyamat megvalósítása Magyarországon és Európában 39

III.3. A gazdaságtudományok képzési terület szakjainak tartalma ......................48

III.3.1. Az üzleti és közgazdasági szakterületek áttekintése a Tuning

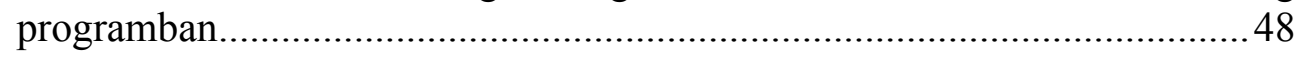

III.3.2. Képzési és kimeneti követelmények a gazdaságtudományok képzési területen Magyarországon ................................................................. 51

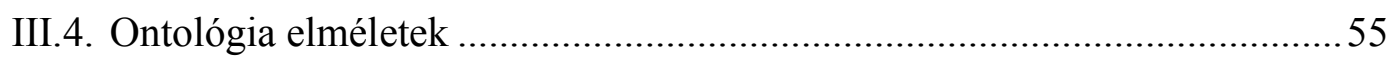

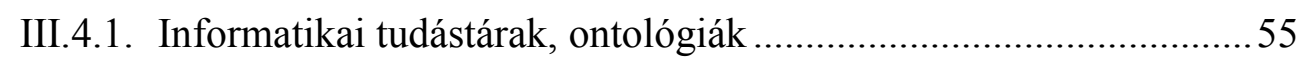

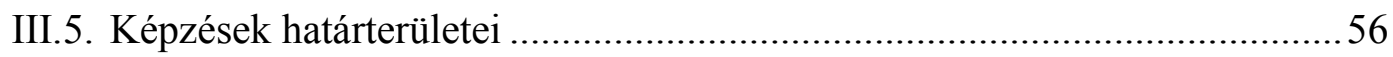

III.6. Áttekintés a középiskolai informatika tananyagról ..................................60

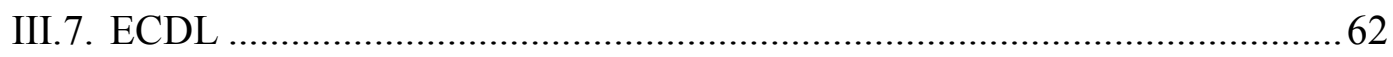

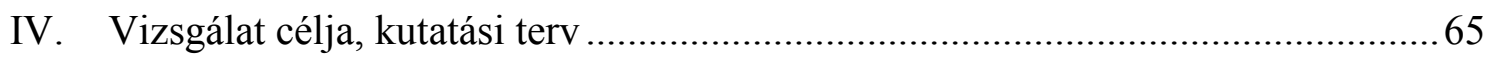

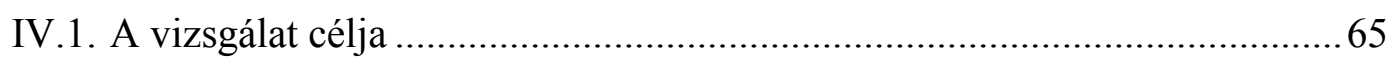

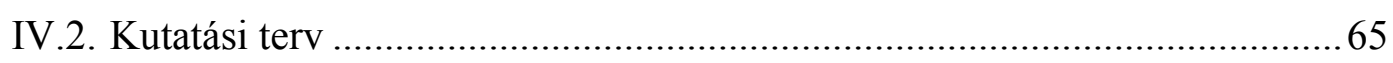

IV.2.1. A jelenlegi gyakorlat - dokumentumelemzéssel .........................66

IV.2.2. A bejövő hallgatók informatikai előismeretei - kérdőíves felmérés

IV.2.3. A szaktárgyak és a módszertani tárgyak oktatóinak tapasztalatai és gyakorlata - interjúk........................................................................ 68 
IV.2.4. A végzett hallgatók munkahelyi tapasztalatai - kérdőíves felmérés 68

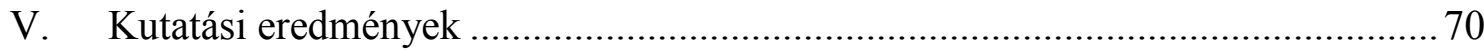

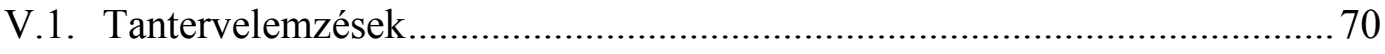

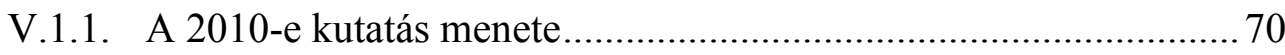

V.1.2. Eredmények, következtetések az operatív tantervekből és tantárgyi

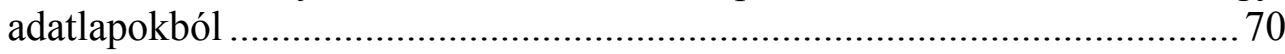

V.1.3. Informatika tárgyak a Budapesti Corvinus Egyetemen és az Általános Vállalkozási Föiskolán ............................................................................ 72

V.1.3.1. Üzleti szakok.......................................................... 73

V.1.3.2. Közgazdasági szakok és Emberi erőforrások szak ....... 75

V.1.4. Európai példák áttekintése ........................................................ 76

V.1.4.1. Aston Egyetem, Anglia ............................................. 76

V.1.4.2. Maribori Egyetem, Szlovénia ...................................... 80

V.1.5. A tantervelemzések összefoglalása........................................... 81

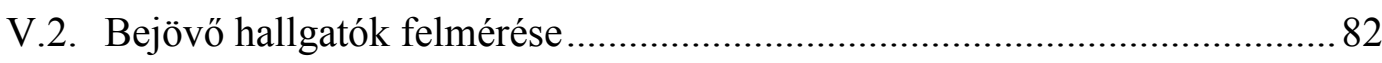

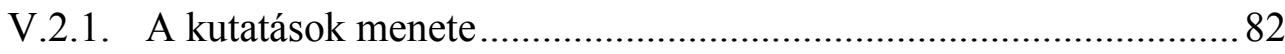

V.2.2. A 2012-es és a 2013-as kutatás eredményei ................................. 82

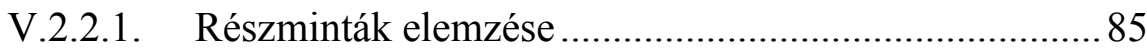

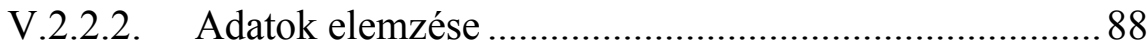

V.2.3. A 2005-06-os és a 2012-es kutatási eredmények összehasonlítása 97

V.2.4. A 2013-as kutatás eredményei a vélt és valós tudás összehasonlításával kapcsolatban............................................................ 98

V.2.5. A bejövő hallgatók informatikai előismereteit kutató kérdőíves felmérések eredményeinek összefoglalása................................................ 105

V.3. Interjúk: szaktanszéki és módszertani kollégákkal ................................ 107

V.3.1. Tanszéki interjúk az Általános Vállalkozási Főiskolán................ 107

V.3.2. Tanszéki interjúk a Budapesti Corvinus Egyetemen ................... 109

V.3.3. Az interjúk tanulságainak összefoglalása .................................. 110

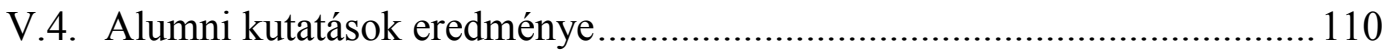

V.4.1. Kísérleti kutatás az Általános Vállalkozási Főiskola végzettjei körében

V.4.2. Budapesti Corvinus Egyetem alumni vizsgálat, 2013-14.

V.4.2.1. A 2012-es ÁVF és a 2013-14-es BCE kutatás eredményeinek összehasonlítása.............................................. 121

V.4.2.2. Informatikai feladatok végzésének gyakorisága és

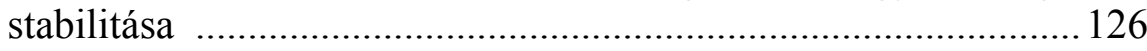

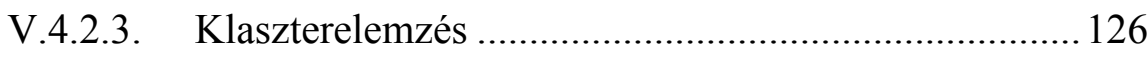

V.4.2.4. A nyílt kérdésekre adott válaszok elemzése ............... 129 
V.4.3. Az alumni kutatások eredményeinek összefoglalása

V.5. A bejövő hallgatók és az alumni körében végzett felmérés összevetése ... 131

VI. Következtetések és tervek az alapozó informatika oktatásra vonatkozóan ..........134

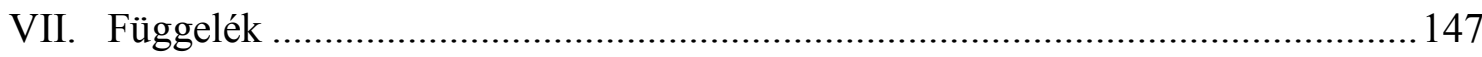

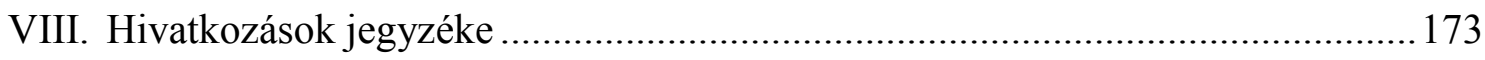

IX. A témakörrel kapcsolatos saját (és társszerzős) publikációk jegyzéke ................ 183 


\section{ÁBRÁK JEGYZÉKE}

1. ábra A közgazdásági és üzleti szakokon szükséges informatikai kulcskompetenciák (saját szerkesztés)... 17

2. ábra Bloom taxonómiája (saját szerkesztés) ….........................................................22

3. ábra A tanulási eredmények evolúciója [Allan - 1996, p. 101.] ..................................2 24

4. ábra: A kompetenciák jéghegymodellje Spencer [1997 p. 8.] alapján (saját szerkesztés,

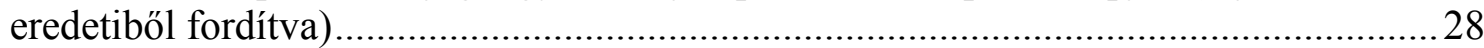

5. ábra A kétciklusú képzés bevezetésének állapota 2010/11-ben [European Commission, 2012 p. 32.]

6. ábra $\mathrm{Az}$ első ciklus befejezése után két éven belül a második ciklusba lépők aránya2010/11-ben [European Commission, 2012 p. 39.]

7. ábra A nemzeti képzési keretrendszerek (NKKR) fejlesztésének haladása 2010/11-ben [European Commission, 2012 p. 46.]

8. ábra A kreditrendszer bevezetésének szintje 2010/11-ben [European Commission, 2012 p. 47.]

9. ábra A szakok képzési és kimeneti követelményeinek kidolgozásakor folytatott szakmai egyeztetések [Vámos, 2010 p. 33.]

10. ábra A Budapesti Corvinus Egyetem nappali tagozatos gazdaságtudományi szakos hallgatóinak tudásszintje saját bevallásuk alapján a saját átlagukhoz képest. (Saját szerkesztés) .89

11. ábra A Budapesti Corvinus Egyetem nappali tagozatos gazdaságtudományi szakos hallgatóinak megoszlása ECDL alapvizsgák és informatika érettségi megléte szerint a 2012-es adatok alapján. (Saját szerkesztés) .93

12. ábra A Budapesti Corvinus Egyetemet a 2005-06-os tanévben illetve a 2012-13-as tanévben kezdő nappali tagozatos hallgatóinak tudásszintje, illetve az egyes területek középiskolai tanítottságának aránya.(Saját szerkesztés). .98

13. ábra A BCE elsős hallgatóival 2013-ban kitöltetett kérdőív szövegszerkesztési alapismeretekre rákérdező tesztkérdése (saját szerkesztés). 100

14. ábra A BCE elsős hallgatóival 2013-ban kitöltetett kérdőív hosszú dokumentum szerkesztésre rákérdező tesztkérdése (saját szerkesztés) 100

15. ábra A BCE elsős hallgatóival 2013-ban kitöltetett kérdőív abszolút-relatív hivatkozások kezelésére rákérdező tesztkérdése (saját szerkesztés). 102

16. ábraA BCE elsős hallgatóival 2013-ban kitöltetett kérdőív programozási ismeretekre rákérdező tesztkérdése (saját szerkesztés) 104

17. ábra Számítógép előtt töltött munkaidő az ÁVF alumni kutatás kitöltőinél (2012) (Saját szerkesztés)

18. ábra A sokdimenziós skálázás eredménye a szövegszerkesztő használatának gyakoriságára 2 dimenzióban (saját szerkesztés). 116

19. ábra A sokdimenziós skálázás eredménye a táblázatkezelő használatának gyakoriságára 2 dimenzióban (saját szerkesztés). 
20. ábra Az összevont változók gyakorisági eloszlása, ÁVF alumni 2012 (saját

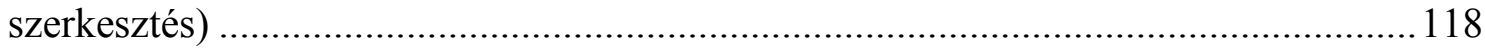

21. ábra A válaszadók végzésének éve, BCE alumni, 2013-14 (saját szerkesztés) ......121

22. ábra Számítógép előtt töltött munkaidő, BCE alumni, 2013-14 (saját szerkesztés)123 


\section{TÁBLÁZATOK JEGYZÉKE}

1. táblázat A tanár- és a tanuló-központú tanulás összehasonlítása Stephen Adam

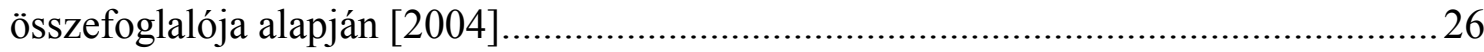

2. táblázat Kulcskompetenciák csoportosításának összehasonlítása................................32

3. táblázat A bolognai folyamat összefoglalása 1998-tól 2009-ig [EHEA, 2012b p. 15]34

4. táblázat Kompetenciák fontossági rangsora az egyes érintettek szerint (Forrás: González - Wagenaar, 2008 pp. 46-47.).

5. táblázat A kommunikációs, az együttmüködési és a problémamegoldó kompetencia megjelenése a Nemzeti alaptantervben és a kétszintü érettségi követelményrendszerében [Vass, 2006] 48

6. táblázat Az üzleti szakokat létesítő konzorciumok [közli Négyesi Judit szakreferens,

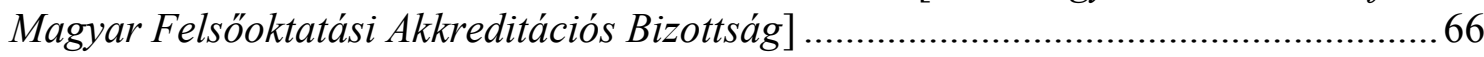

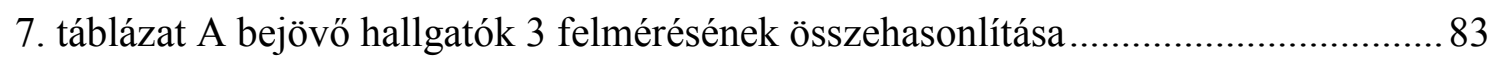

8. táblázat A 2012-es és a 13-as kutatásban megkérdezett témakörök .......................... 84

9. táblázat A 2012-13-as előismereti kérdőív kitöltési arányai az egyes intézményekben az egyes képzési területeken részidős $(\mathrm{R})$ és nappalis $(\mathrm{N})$ képzésben .............................. 85

10. táblázat A BCE gazdaságtudományi nappali szakos hallgatóinak mutatói (saját szerkesztés) .90

11. táblázat A Budapesti Corvinus Egyetem nappali tagozatos gazdaságtudományi szakos hallgatóinak tudásszintjének és az adott terület középiskolai tananyagban szereplésének összefüggése a kapcsolat szorossága szerint csökkenő sorrendben (saját szerkesztés).. 91

12. táblázatA Budapesti Corvinus Egyetem levelező tagozatos gazdaságtudományi szakos hallgatóinak tudásszintjének és az adott terület középiskolai tananyagban szereplésének összefüggése a kapcsolat szorossága szerint csökkenő sorrendben 2013ban (saját szerkesztés)

13. táblázat A Budapesti Corvinus Egyetem nappali tagozatos gazdaságtudományi szakos hallgatói által a Microsoft termékeken kívül használt programok említésszáma a 2013ban (saját szerkesztés) 94

14. táblázat A Budapesti Corvinus Egyetem levelező tagozatos gazdaságtudományi szakos hallgatói által a Microsoft termékeken kívül használt programok említésszáma a 2013-ban (saját szerkesztés). .95

15. táblázatA Budapesti Corvinus Egyetem nappali és levelező tagozatos gazdaságtudományi szakos elsős hallgatóinak számítógépes tevékenységgel töltött ideje 2013-ban (saját szerkesztés). .96

16. táblázat Szövegszerkesztővel hosszú dokumentum készítése (címsorok, tartalomjegyzék, szakaszok, hasábok, lábjegyzet) önbevalláson alapuló ismerete és az erre rákérdező teszten elért eredmény összefüggése 2013-ban a BCE elsős hallgatóinál (saját szerkesztés). 101

17. táblázat Táblázatkezelési és prezentációs feladatok önbevalláson alapuló ismerete és a hosszú dokumentum szerkesztésére rákérdező teszten elért eredmény összefüggése 2013-ban a BCE elsős hallgatóinál (saját szerkesztés) 102 
18. táblázat Szövegszerkesztési, táblázatkezelési, prezentációkészítési és adatbáziskezelési feladatok önbevalláson alapuló ismerete és az abszolút-relatív hivatkozás használatára rákérdező teszten elért eredmény összefüggése 2013-ban a BCE elsős hallgatóinál (saját szerkesztés) 103

19. táblázat Táblázatkezelő egyszerü használatának önbevalláson alapuló képessége és az erre rákérdező teszten elért eredmény összefüggése 2013-ban a BCE elsős hallgatóinál (saját szerkesztés). 103

20. táblázat Programozás önbevalláson alapuló ismerete és az erre rákérdező teszten elért eredmény összefüggése 2013-ban a BCE elsős hallgatóinál (saját szerkesztés) ........... 105

21. táblázat Kérdőív kitöltési arány szakcsoportonként és összesen, ÁVF alumni 2012 (saját szerkesztés).

22. táblázat Számítógépes munkavégzés jellege, ÁVF alumni 2012 (saját szerkesztés) 114

23. táblázat Az összevont változók statisztikai adatai, ÁVF alumni 2012 (saját szerkesztés)

24. táblázat A táblázatkezelő leggyakrabban használt funkciói, ÁVF alumni 2012 (saját szerkesztés)

25. táblázat A válaszadók szakjai és szakirányai, BCE alumni, 2013-14 (saját szerkesztés)

26. táblázat A cég mérete, és a kitöltők beosztása, BCE alumni, 2013-14 (saját szerkesztés)

27. táblázat A végzés évtizede és az informatikai követelmény aránya a munkahelyi felvételi eljárásban, BCE alumni, 2013-14 (saját szerkesztés) 122

28. táblázatA munkahelyi felvételi eljárásban szereplő informatikai követelmények elöfordulási aránya, BCE alumni, 2013-14 (saját szerkesztés). 123

29. táblázat Számítógépes munkavégzés jellege, BCE alumni, 2013-14 és ÁVF alumni 2012 összehasonlítás (saját szerkesztés) .

30. táblázat A munkahelyen használt, korábban nem ismert programok említésszáma, BCE alumni, 2013-14 (saját szerkesztés).

31. táblázat A munkahelyen használt, korábban nem ismert programok említésszáma, BCE alumni, 2013-14 (saját szerkesztés).

32. táblázat $\mathrm{Az}$ informatikai feladatok gyakorisága alapján képzett klaszterek klaszterközepei, BCE alumni, 2013-14 (saját szerkesztés). 128

33. táblázatEltérés az alumni és a bejövő hallgatók kompetenciái között,BCE alumni és bejövő hallgatói kérdőív, 2013-14 (saját szerkesztés) 132

34. táblázat Megrendelések kezeléséről szóló komplex esettanulmány során felmerülő problémák és a megoldásukhoz szükséges eszközkészlet (A probléma leírásánál zárójelben a problémaszinteket jeleztem). 
DOI: $10.14267 /$ phd.2014081 


\section{KÖSZÖNETNYILVÁNÍTÁS}

Egy doktori disszertáció elkészítése mindig összetett folyamat. Különösen így van ez akkor, ha a téma több tudományterületet érint és a kutatás több évet felölel. Mindenek elött szeretnék köszönetet mondani jelenlegi témavezetőmnek Dobos Imrének. Köszönetet kell mondanom korábbi témavezetőimnek, Quittner Pálnak, aki már egyetemi éveim alatt is meghatározó tanárom volt, Bíró Miklósnak, aki már a kezdetektől látott fantáziát az elképzeléseimben, és Gábor Andrásnak, aki bíztatott és segített végső keretbe foglalni az addigi munkámat. Nem szabad megfeledkeznem Csapó Benőről sem, akitől a szegedi Neveléstudományi Doktori Iskolában a pedagógiai gondolkodás és kutatások alapjait sajátítottam el. Doktori tanulmányaim és kutatásaim során a módszertanban, statisztikai elemzésekben Füstös László tanár úrra bármikor számíthattam, amit nem fogok tudni neki eléggé megköszönni.

Hálás vagyok még azon intézmények munkatársainak, akik az empirikus kutatásokban segítettek a Budapesti Corvinus Egyetemen, az Általános Vállalkozási Főiskolán és a Budapesti Kommunikációs Főiskolán.

Sokat köszönhetek számos közvetlen, vagy távolabbi kollégának, akiktől a közös munka során, vagy csak szemléletformáló beszélgetések keretében nagyon sokat tanultam, közülük is ki kell emelnem Lévayné Lakner Máriát, Németh Zoltánt, Haskó Józsefet, Lipécz Györgyöt, Csépai Jánost, Veszprémi Annát, Helfenbein Henriket, Vig Zoltánt, Réger Bélát, Tóth Margitát, Nina Rizunt, Kis Mártát és Béres Ilonát.

Köszönöm a fordításban nyújtott segítséget Kovács-Gémes Juliannának és Vas Rékának. A szakmai köszönetnyilvánítások mellett nem feledkezhetek meg családomról sem, hiszen a tanulásra, kutatásra fordított időt tőlük kellett elvonnom, az ő támogatásuk, megértésük és segítségük nélkül ez soha nem sikerült volna. Köszönöm tehát Rolandnak, Dávidnak, Máténak, a szüleimnek és Erzsinek. 
DOI: $10.14267 /$ phd.2014081 


\section{BEVEZETÉS}

Évtizedes oktatási tapasztalatom során gyakran szembesültem azzal a problémával, hogy az oktatott tárgyak tartalma az oktató kollégákkal folytatott viták alapján bövült, szükült, változott, de hiányzott a cél meghatározása és így ezek a viták parttalanok voltak. A tananyagok nagyjából az alapján alakultak ki, hogy mi oktatók mit szerettünk volna megtanítani. Ezt a dolgozatot az a törekvés inspirálta, hogy a közgazdasági és üzleti felsőoktatásban (gazdaságtani képzési terület) az alapozó informatika oktatás valóban azokra a kulcskompetenciákra terjedjen ki, amit ez a szakterület megkíván.

Az első fontos lépés már az elhatározással megszületett, a tanárközpontú tanításról kívántam áttérni a kimeneti oldalra koncentráló, tanulóközpontú tanításra. Ezt az alapvető gondolati váltást támasztja alá a fellelhető széleskörü pedagógiai szakirodalom, melyet a III.1. fejezetben mutatok be és az európai felsőoktatás átalakulását az utóbbi években meghatározó bolognai folyamat, amiröl a III.2. fejezetben számolok be. Ezekben a fejezetekben tisztázom a dolgozat során használt alapfogalmakat, úgymint: kompetencia, tudás, ismeret, készség, képesség, attitüd, tanulási eredmény, tanuló központú tanítás. A dolgozatban használt kompetencia fogalom struktúrája megtekinthető az 1. mellékletben. A konkrét szakterület, amit ezen elvek mentén dolgozok fel, a gazdaságtani képzési terület szakjain szükséges informatikai kulcskompetenciák. A gazdaságtani képzési terület a magyar képzési és kimeneti követelmények alapján és a nemzetközi irodalomban is két szakcsoportra oszlik, a közgazdasági és az üzleti szakokra. Magyarországon a közgazdasági szakok az alkalmazott közgazdaságtan, a gazdaság- és pénzügy-matematikai elemzés (korábban gazdaságelemzés) és a közszolgálati, az üzleti szakok pedig az emberi erőforrások, a gazdálkodási és menedzsment, a kereskedelem és marketing, a nemzetközi gazdálkodás, a pénzügy és számvitel, a turizmus-vendéglátás és az üzleti szakoktató. A dolgozat ez utóbbival (üzleti szakoktató) nem foglalkozik. A képzési terület áttekintését III.3. fejezetben teszem meg.

Mivel informatikaoktatásról van szó, fontosnak tartom az informatikai tudástárak megemlítését a III.4. fejezetben, de a hangsúlyt elsősorban a tudományterületek érintkezési pontjaira helyezem a III.5. fejezetben. 
A középiskolai tananyag törvényi áttekintése a III.6. fejezetben, az eléggé elterjedt informatikai felhasználói vizsgarendszer, az ECDL áttekintése pedig a III.7. fejezetben olvasható.

Az elméleti áttekintés mellett empirikus vizsgálatokat is végeztem a téma precízebb körüljárása érdekében. A kutatások tervét a IV., a konkrét eredményeket pedig a V. fejezetben mutatom be. A vizsgálatok több forrásra támaszkodnak. A jelenlegi és a végzett hallgatókat kérdőívvel kerestem meg. A tudomány és az oktatók szempontját az oktatókkal folytatott interjúkkal és szakirodalmi kutatással térképeztem fel. A jelenlegi gyakorlat vizsgálatához dokumentumelemzést alkalmaztam. 


\section{PROBLÉMAFELVETÉS}

A dolgozat koncepciójának áttekintését adja az 1. ábra. Az elsődleges cél, hogy a hallgatók kilépve a munkaerőpiacra jól boldoguljanak. A munka világa viszont dinamikusan változik, és annak meghatározása sem egyértelmü, hogy a vizsgált szakokon végzett hallgatók ebben a világban pontosan hol fognak megjelenni. A képet tovább árnyalja a folyamatosan jelen lévő technológiai fejlődés, a szektorális különbségek és az egyes munkahelyekre jellemző heterogén követelmények. Ezt a dinamikusan változó, heterogén követelménycsoportot ez a dolgozat nem tudja maradéktalanul felmérni. Ezzel szemben a felsőoktatásban létezik egy konkrét, statikus követelményrendszer, melyet a képzési és kimeneti követelmények írnak le. Izgalmas feladat a képzés olyan kialakítása, hogy az megfeleljen a statikus képzési és kimeneti követelményeknek, ugyanakkor lehetőleg felkészítse a hallgatókat a dinamikusan változó környezetre, amivel a munka világában fognak találkozni.

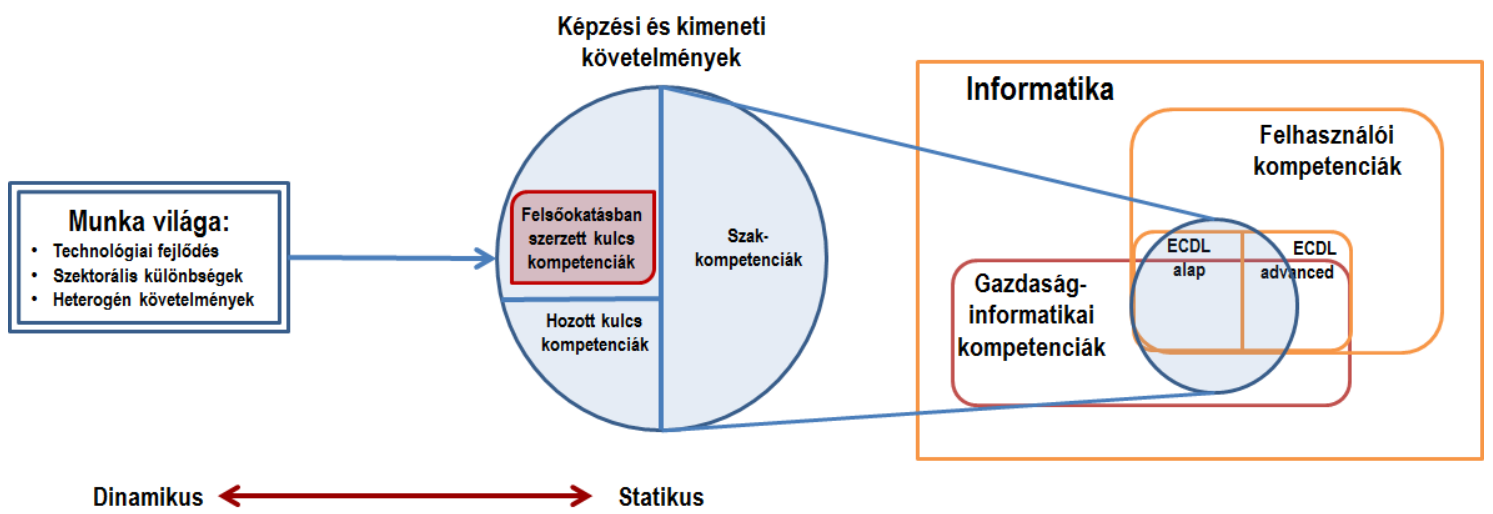

1. ábra A közgazdásági és üzleti szakokon szükséges informatikai kulcskompetenciák (saját szerkesztés)

A képzési és kimeneti követelmények tartalmaznak kulcs- és szakkompetenciákat is, ezek közül az utóbbiakat jobban érintik a változások, bár a szükséges kulcskompetenciák köre is változik idővel, de lassabban. Például a napjainkban egyre jobban fejlődő mobil informatikához kapcsolódó kompetenciák rövid időn belül megkerülhetetlenek lesznek, míg pár éve nem is léteztek. A szakkompetenciák csak érintőlegesen szerepelnek a dolgozatban, mivel azok nem az alapozó informatikaoktatásban tudnak megjelenni. Az alapozó informatikaoktatás jellemzően a képzés elején, első vagy második félévben szerepel.

Az információs társadalom fejlődéséből következő tendencia, hogy a hallgatók már nem az informatikai kompetenciák teljes hiányával lépnek a felsőoktatásba. Szükséges tehát 
azt is kiderítenünk, hogy mit hoznak magukkal a hallgatók, amit akár a középiskolában, formális keretek között, akár informális utakon sajátítottak el.

A fentieket figyelembe véve doktori dolgozatomban a következő kérdésekre keresem a választ:

(K1) Mi legyen a célja és a tartalma az informatika alapozó kurzusoknak a gazdaságtudományok képzési terület szakjain?

A fö kérdés megválaszolásához az alábbi kérdésekre is választ keresek:

(A1) A képzési és kimeneti követelmények és az európai uniós iránymutatások alapján milyen informatikai kompetenciákra van szükség a gazdaságtani képzési területen, azon belül a közgazdasági és üzleti képzési szakokon?

(A2) Milyen informatikai képzésben részesülnek jelenleg a gazdaságtani képzési terület hallgatói?

(A3) Milyen eltérések tapasztalhatók a képzési és kimeneti követelmények valamint az európai uniós iránymutatások és a jelenlegi hazai gyakorlat között?

(A4) Milyen kiinduló ismeretekre és képességekre támaszkodhatunk a képzés során?

(A5) Milyen informatikai kulcskompetenciákra van szüksége a munkába lépõ diplomásoknak a gazdaságtani képzési területen, az üzleti és közgazdasági szakokon?

(A6) Melyik területeken van eltérés a munkahelyen szükséges és a már az egyetemre lépéskor meglévö informatikai kulcskompetenciák között?

A kutatási eredmények validálásához szükséges az elméletileg igazolt megállapítások gyakorlati implementációja. Ennek egy lehetséges formája egy korszerü, a bolognai folyamatnak, a képzési és kimeneti követelményeknek és a munkahelyi elvárásoknak megfelelö, a peremfeltételeket figyelembe vevö tananyag összeállítása. 


\section{SZAKIRODALMI ÁTTEKINTÉS}

\section{III.1. Pedagógiai elméletek, tananyagfejlesztés}

A közoktatásban dolgozó tanárok képzésének része a pedagógiai felkészítés is. Ez a felsőoktatásban dolgozó kollégáknál nincs feltétlenül így. Általában véve is az a tapasztalat, hogy a felsőoktatásban a pedagógiai szempontoknak kevesebb szerep jut és tantervelméletekről is elsősorban a közoktatásra vonatkozóan van széleskörü szakirodalom, de ezekben is vannak hasznosítható pontok a felsőoktatásra nézve is [Ballér,2004; Báthory,2000; Szebenyi, 1994]. Az utóbbi évek európai folyamatai, elsősorban a bolognai folyamat kapcsán, egyre nagyobb hangsúlyt helyeznek a pedagógiai megközelítésre a felsőoktatásban is. [Fischer-Halász, 2009; Tuning, 2009; Vámos, 2010] A következökben a fontosabb tantervi és tananyag-fejlesztési elméleteket és megfontolásokat fogom áttekinteni.

\section{III.1.1. Kinek a feladata a tantervkészítés?}

Fontos meghatározni, hogy kinek a feladata a tantervkészítés. A történelem során felmerült lehetőségek a tudós egyetemi tanárok, a politikusok, a pedagógusok és a tantervi szakértők. [Szebenyi, 1994] A tantervelméletek evolúciója során számos alkalommal kifejezésre került, hogy a jó tanterv létrehozásához szükség van a különböző szereplők együttmüködésére, így a tudomány, az oktatók, a hallgatók és a munkaeröpiac kommunikációjára. [Szebenyi, 1994]

A lovagkori „természetes tantervek” definíciója a következőképpen hangzott: „,nemzedékről nemzedékre öröklődik, az élethez és a munkához szükséges ismereteket és képességeket fejleszti, a tudományos-technikai fejlődéssel gazdagodik"[Szebenyi,1994: 346. o.] A jelenkorban a fejlődés felgyorsult, így a definíció első pontja már nem alkalmazható maradéktalanul, de a másik két pont ma is igaz kéne, hogy legyen.

Ennek fényében érdekes kiemelni Bourdieu tantervfejlesztési alapelveiből néhányat: „a színvonal megőrzésével végrehajtott tananyagcserékkel az oktatás anyagát hozzá kell igazítani a tudományos és társadalmi változásokhoz”, „,törekedni kell a szakterületek közötti egyensúlyra és integrációra”. [Varga, 1991] 
A Ralph Tyler által 1949-ben publikált tantervelmélet (elterjedt nevén Tyler racionálé) szerint a tananyag-kiválasztás forrásai a tanuló tanulási szükségletei, érdeklődései, aspirációi, a kortárs társadalom igényei az iskola, a müveltség iránt és a szaktudományok képviselői által relevánsnak tartott tudás köre. [Báthory, 2000; Csapó, 1991; Tyler, 1949] Az Európa 2020 stratégia keretében kiemelt célként jelenik meg az egész életen át tartó tanulás, ezen belül a munkaerőpiacok modernizálása. [Csernovitz - Szegedi (szerk.), 2012] Kiemelt kezdeményezés az „Új készségek és munkahelyek menetrendje” melynek tagállami szinten az egyik alpontja: „Az oktatás/képzés és a munka világa közötti partnerségek létrehozása, különösen a szociális partnereknek az oktatási és képzési igények tervezésébe való bevonása révén." [European Commission, 2010 pp. 21-22.]

\section{III.1.2. Bloom taxonómiája}

A tantervfejlesztés fejlődésével egyre nagyobb hangsúly helyeződött az outputra. A Tyler racionáléból hiányzott a követelmények meghatározása, ezzel Bloom egészítette ki az elméletet 1956-ban megjelent müvében, melyet egy kutatócsoport élén szerkesztett és azóta Bloom taxonómiája néven a pedagógiai tanulmányok egyik alapmüve. A kutatók a tanulási célok rendszertanát dolgozták ki elsősorban azzal a céllal, hogy az értékeléshez készített tesztfeladatokat csoportosítani lehessen. Az eredmény azonban egy egyszerü osztályba soroláson túl jóval szélesebb körben használható elméleti keretrendszer és gyakorlati segédlet lett.

A tanulási célokat 3 tartományba osztották: kognitív (értelmi), pszichomotoros és affektív. Ezek közül a kognitívrész került leginkább kibontásra. Az affektív tartományt is kidolgozták, bár kevésbé részletesen, de a pszichomotoros tartomány kifejtése nem készült el, mert a kutatócsoport úgy gondolta, hogy ehhez nincs elég tapasztalatuk. A későbbiek folyamán több kutató és kutatócsoport foglalkozott a pszichomotoros tartomány osztályozásával.

Bloom taxonómiája az értelmi tartományban a következö követelményszinteket határozta meg: 1. ismeret, 2. megértés, 3. alkalmazás, 4-6. magasabb szintü müveletek: 4. elemzés, 5. szintézis, 6. értékelés. [Báthory, 2000; Bloom, 1956; Perjés - Vass, 2009].

Az osztályokon belül további alosztályokat is megfogalmaztak, és ami a gyakorlati használhatóságot a leginkább megnövelte, az egyes alosztályokhoz számos cselekvő igét rendeltek, melyek az adott tudásszint értékeléséhez kapcsolódnak (pl.: felidéz, emlékszik, felsorol, részekre bont, összehasonlít, stb.) 
Az eredeti kutatócsoport egyik tagjának, David R. Krathwohlnak a vezetésével a 90-es években újragondolták, és a pedagógusok gyakorlatát is figyelembe véve átdolgozták a taxonómia kognitív tartományát, amit 2001-ben jelentettek meg a Bloom taxonómia átdolgozása néven [Krathwohl, 2002]. Az eredeti taxonómiát alapul véve a föbb különbségek:

- egy dimenzióból két dimenzióba: Az eredeti taxonómia első eleme, az ismeret kettős tartalmat hordozott, egyrészt a megnevezését az egyes ismeretelemeknek, másrészt a kognitív folyamatot. A átdolgozásban ezt a kettősséget úgy oldották fel, hogy kétdimenzióssá tették a modellt. Az egyik dimenzióba került az egyes ismeretelemek megnevezése (jellemzően főnevek), a másikba pedig az eredeti hat szintnek megfelelő kognitív folyamatok (jellemzően igék). Az új dimenzió fokozatai az eredeti ismeret 3 alpontjának felelnek meg, kiegészítve egy negyedikkel: tárgyi ismeret (factual knowledge), fogalmi ismeret (conceptual knowledge), procedurális (folyamat jellegü) ismeret (procedural knowledge) és az új metakognitív ismeret (metacognitive knowledge).

- főnevek helyett igék: Az eredeti 6 szint megnevezését kissé megváltoztatták, a főneveket mindenütt igére cserélték, és 3 kategória esetében a tantervekben leggyakrabban használt kifejezések figyelembevételével a szót is megváltoztatták: ismeret -emlékszik (knowledge - remember), felfogás - megért (comprehension - understand), alkalmazás - alkalmaz (applicaton - apply), elemzés - elemez (analysis - analyze), szintézis - alkot (synthesis - create), értékelés - értékel (evaulation - evaulate) (2. ábra)

- sorrendi csere: Az eredeti taxonómiához képest egyetlen sorrendi változás, hogy a felső két szint helyet cserélt.

- kevésbé szigorú hierarchia: Az eredeti elméletben a különböző szintek nem csak sorrendet jelentettek az egyszerü folyamatoktól a komplexekig, hanem az egymásra épülés is megvalósult, azaz például a megértés feltételezte az ismeretet, az alkalmazás képessége feltételezte a megértést és így tovább. Az újragondolt változatban a hierarchia továbbra is igaz, de elképzelhetők a kategóriák közötti átfedések.

- kognitív táblázat: Az átdolgozott elméletnek egy hasznos gyakorlati hozadéka, hogy a kétdimenziós megközelítésnek köszönhetően az egyes tananyagelemek elhelyezhetők egy kétdimenziós táblában. Ha egy kurzus, vagy egy tananyag minden egyes ré- 
szét elhelyezzük a táblázatban, akkor vizuális segítséget kapunk ahhoz, hogy áttekintsük a teljes kurzus tanulási céljait, a táblázatban üresen maradt területekre fókuszálhatunk, esetleges átdolgozással egyenletesebbé tehetjük a tananyagot.[Krathwohl, 2002]

\section{Magasabb szintű mưveletek}

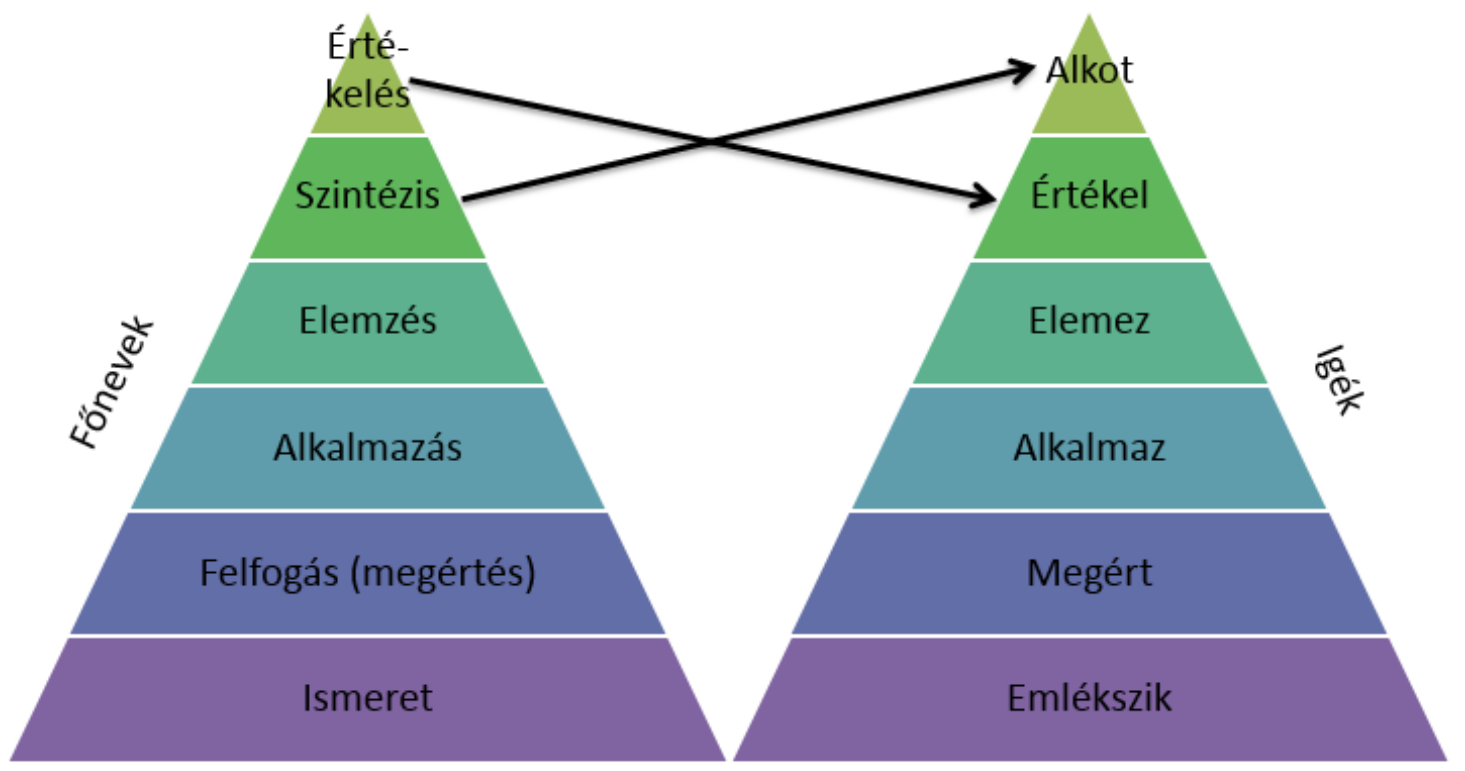

\section{Alacsonyabb szintű múveletek}

Bloom eredeti taxonómiája

Bloom módosított taxonómiája

\section{2. ábra Bloom taxonómiája (saját szerkesztés)}

A köztudatban sokkal inkább él Bloom eredeti taxonómiája, bár a gyakorlatban gyakran a „módosított” taxonómiát használják. Nem véletlen, hogy az elmélet a nevében is megörizte az eredeti alkotót.

Az affektív tartomány felosztása Bloom tanulmányában: befogadás, reagálás, értékekhez való viszony, szervezett formába alakítás, jellemzővé válás. [Kennedy, 2007]

A pszichomotoros tartomány egy lehetséges felosztása: utánzás, végrehajtás, pontosság, együttes alkalmazás, természetessé válás. [Dave, 1970]

Az informatika egy része ebbe a tartományba eshet [Kennedy, 2007], pl. vakon gépelés, informatikai eszközök (pl. egér) használata.

2005-ben publikálták a pszichomotoros tartomány értelmezését a mérnökképzés labormunkáit tartva szem elött. [Ferris - Aziz, 2005]

- eszközök és anyagok felismerése 
- eszközök és anyagok kezelése

- eszközök alapszintü használata

- eszközök hozzáértő (kompetens) használata

- eszközök szakértő használata

- munkafolyamatok megtervezése

- végeredmény értékelése és a javítás módjának megtervezése[Ferris - Aziz, 2005]

Az informatikai alkalmazások eszközeinek használata a kognitív tartományba tartozik, azon belül az alkalmazás szintjéig kell eljutnia a felhasználóknak. Bár Ferris és Aziz [2005] fizikai eszközök használatára dolgozták ki elméletüket, úgy vélem, hogy az első két pont kivételével a kognitív tartomány alkalmazás szintjének további felbontására is alkalmazhatóak ezek a szintek. Konkrét példával élve, a táblázatkezelő programok kimutatás eszközének alkalmazása lehet alapszintű (tudja a felhasználó, hogy hol találja az eszközt, és egyszerü kimutatást el tud vele készíteni). Hozzáértő használat esetén több szintű csoportosítást is be tud állítani és tudja változtatni a kimutatásban használt összesítő függvényt. Szakértő használat esetén ismeri és használja a különböző speciális beállításokat, tudja finomítani az elkészített kimutatást. Az alkalmazás egy magasabb szintje, hogy egy adott felmerülő probléma esetén tudja a felhasználó, hogy ezt az eszközt kell hozzá használnia. A legmagasabb szinten már azt is tudja, hogy egy hibásan elkészített kimutatásban mi okozza a hibát, vagy milyen beállítással lehetne informatívabb, jobban használható kimutatást készíteni.

A dolgozat további részében Bloom eredeti taxonómiáját fogom használni, és abban az alkalmazás szint itt bemutatott további felosztását.

\section{III.1.3. A tanulási eredmények evolúciója}

Már Tyler racionáléjában megfogalmazásra került, hogy egy oktatási program tervezésénél nagyon fontos, hogy legyen a céloknak egy koncepciója, amire a program irányul. Ezek az oktatási célok (educational objectives) alkotják a kritériumrendszert, ami alapján a tananyagok kiválasztásra kerülnek, a tartalmak körvonalazódnak, a folyamatok fejlődnek és a tesztek és vizsgák készülnek. Tyler definíciója szerint az oktatási célok: ,azok a viselkedésbeli változások, amelyeket az oktatási intézmény a hallgatókban létre kíván hozni." [Tyler - 1949 p.6.; Allan - 1996]

A Tyler által megfogalmazott oktatási célok hosszú evolúciós folyamaton mentek keresztül, melyet a 3. ábra szemléltet. Ennek az evolúciónak volt egy fontos lépcsője, mikor 
Mager oktatási célok helyett irányítási célokat határozott meg (educational instrucitonal), melyek megfogalmazásakor 3 kritériumot kell szem előtt tartania tananyag tervezőjének:

- egyértelmü megfogalmazása annak, hogy mire lesz képes a tanuló a tanulási tapasztalat végén

- milyen körülmények között kell ezt a teljesítményt teljesítenie

- és milyen szinten végrehajtott teljesítmény tekinthető elfogadhatónak. [Mager, 1962]

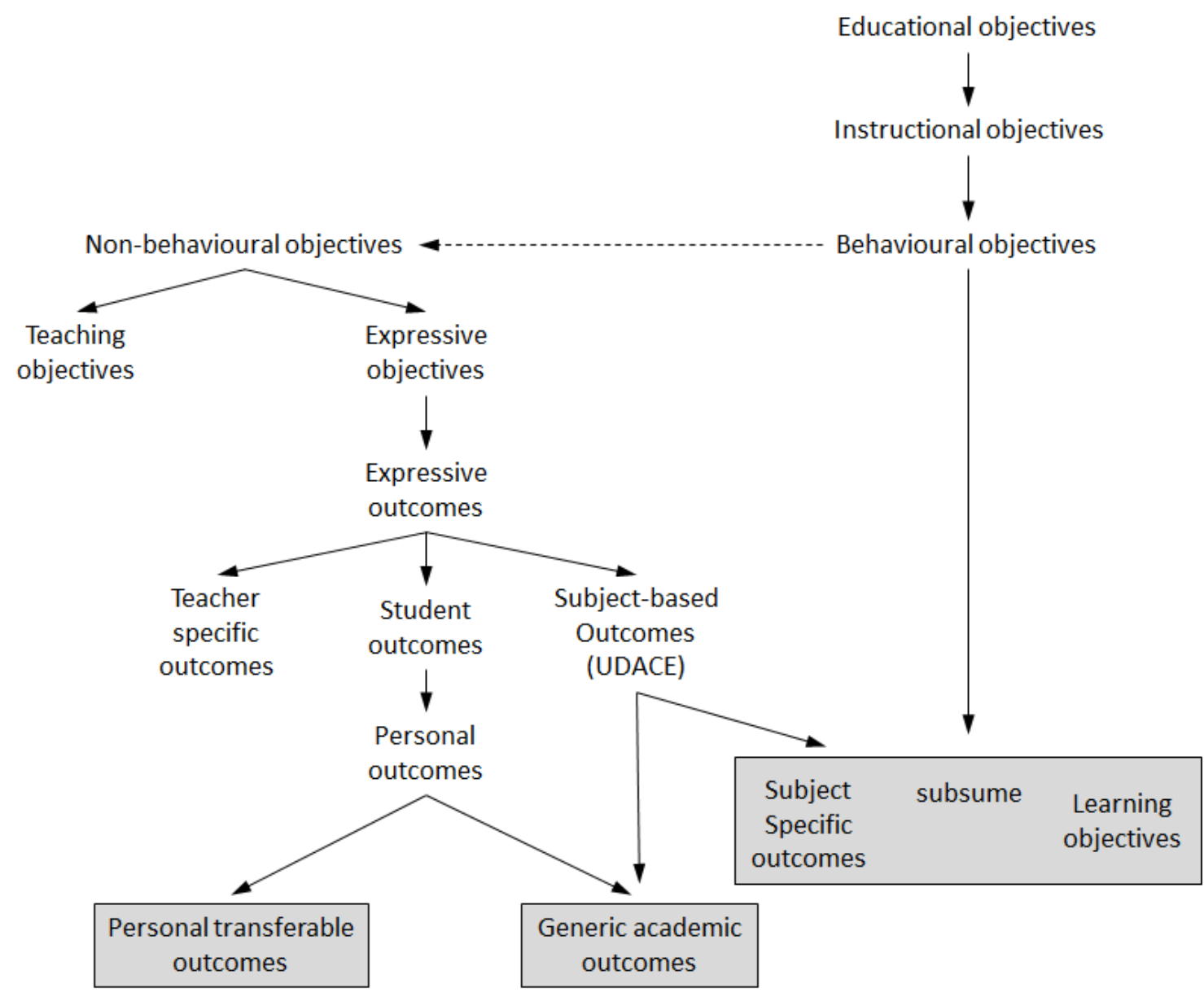

3. ábra A tanulási eredmények evolúciója [Allan - 1996, p. 101.]

Ezzel a célmeghatározással a behaviorista mozgalom nyomta rá a bélyegét a tantervfejlesztésekre. Későbbi kritikái szerint túl konkrét, csak a mérhető célokat veszi figyelembe, holott az oktatásnak ennél szélesebb körü céljai is lehetnek.[Allen, 1996]

A ma legelterjedtebb célrendszer a tanulási eredmények (Learning Outcomes) megfogalmazása és azok használata, melynek számos megfogalmazása létezik, de ezek nem térnek el jelentősen egymástól. Az ECTS felhasználói kézikönyv definíciója: „A tanulási eredmények olyan állítások, amelyek arról szólnak, hogy a hallgatóknak mit kell tudniuk, mit 
kell átlátniuk és/vagy mit kell tudni elvégezniük egy sikeres tanulási szakasz teljesítése után.” [European Commission,2009a p. 11.]

A különböző, egymáshoz nagyon hasonló meghatározások egyetértenek az alábbi két pontban:

- a tanulási eredmények arra irányulnak, amit a hallgató elsajátított, nem pedig pusztán arra a tartalomra, amit megtanítottak neki;

- a tanulási eredmények arra a tudásra irányulnak, amit a hallgató az adott tanulási tevékenység elvégzésekor fel tud mutatni.

A Bloom-féle taxonómiát gyakran használják tanulási eredmények megalkotásához, mivel a taxonómia kész szerkezetet ad, valamint a követelmények leírásához szükséges igéket is tartalmazza. [Kennedy, 2007]

A tanulási eredmények definíciói között találunk olyat is, amely részletezi az eredmények megadásának módját. Ilyen a Jogi Könyvtárak Amerikai Egyesületének definíciója:

„A tanulási eredmények olyan állítások, amelyek azt tartalmazzák, hogy egy hallgató mit fog tudni, illetve mit lesz képes elvégezni egy adott tanulási tevékenység eredményeképpen. Ezek az eredmények általában tudás, képesség vagy attitüd formájában kerülnek meghatározásra." [idézi: Kennedy, D., 2007. p. 19.]

A tudás, képesség, attitűd felosztás a kompetencia fogalmánál jelenik meg jellemzően, így ezeket a következő alfejezetben részletezem.

A tanulási eredmények főbb jellemzői és előnyei Stephen Adam összefoglalója alapján:

- általános igényt támasztanak a precizitásra a kurzusok tervezésében

- segítenek megszüntetni az átfedéseket

- információt nyújtanak a tanulók számára a kurzusválasztáshoz

- biztosíthatják az átjárást a tanulási programok között

- az eredményekre fókuszálnak

- megírhatók egy modulra vagy az egész programra

- aktív igéket használnak (mint Bloom taxonómiája)

- hangsúlyozzák a tanítás-tanulás-értékelés kapcsolatát

- segítik a minőségbiztosítást

- általában kompetenciákban vannak kifejezve

- lehetőséget nyújtanak a szakképzés és a felsőoktatás összekapcsolására 
- javítják a végzettségek nemzetközi elismertetését és átláthatóságát. [Adam, 2004]

Adam felhívja a figyelmet a kritikai észrevételekre is. A tanulási eredmények használata a felsőoktatás programtervezésében:

- akadályozhatja a tanulási folyamatot

- jobban passzol a tréning jellegü oktatáshoz, mint a nyílt végü felsőoktatáshoz

- egy célvezérelt kultúrához vezethet

- megsérti az egyetemek liberális koncepcióját

- technikailag nehéz és drága bevezetni

- a felsőoktatásban dolgozók ellenállásába ütközhet [Adam, 2004]

1. táblázat A tanár- és a tanuló-központú tanulás összehasonlítása Stephen Adam összefoglalója alapján [2004]

\begin{tabular}{|l|c|}
\hline $\begin{array}{c}\text { TANÁR KÖZPONTÚ } \\
\text { TANULÁS }\end{array}$ & \multicolumn{1}{c|}{ TANULÓ KÖZPONTÚ TANULÁS } \\
\hline - a tanár a tudás & $\bullet$ a tanulók nem passzívak, hozzák a saját érzékelési \\
forrása & keretrendszerüket [Erikson, 1984] \\
- a tanulók üres & - a hallgatók különbözö módokon tanulnak [Briggs-Myers, \\
edények és a & $1980 ;$ Kolb, 1984] \\
tanítás additív & - a tanulás egy aktív dinamikus folyamat [Cross, 1991] \\
folyamat & - A tanulók maguk alkotják meg a dolgok jelentését azáltal, \\
- az átlagos & hogy beszélgetnek, hallgatnak, írnak, olvasnak és \\
tanulónak szól, & reflektálnak a tartalmakra, ideákra, vitapontokra és \\
mindenkinek & aggodalmakra [Meyers and Jones, 1993] \\
egyformán & \\
\hline
\end{tabular}

A kritikákkal kapcsolatban azt fontos megjegyezni, hogy az ellenállás gyakran az eltérö értelmezésből ered. A tanulási eredmények megfogalmazása a minimum szintet jelenti, amivel az adott programot sikeresen elvégzők mindenképpen rendelkeznek, nem pedig azt a maximumot, amit az adott program nyújtani tud. Ha így értelmezzük, akkor már nem ütközik akadályba a nyílt végü felsőoktatás összeegyeztetése a tanulási eredmények elméletével. [Derényi, 2006]

A tanulási eredmények megközelítésnek vezető szerepe van a tanterv fejlesztésben, tervezésben. Része egy paradigmaváltásnak: tanár központú tanítás helyett tanulóközpontú tanulás. [Adam, 2004] A két paradigma összehasonlítását mutatja az1. táblázat.

\section{III.1.4. Kompetencia}

A kompetencia fogalmát Noam Chomsky nyelvész professzor alkotta meg, aki a nyelvi képességek vizsgálatakor megkülönböztetett kompetenciát és felhasználást 
(performanciát). Feltételezte, hogy a nyelvi tudás megszerzése nem alapulhat csupán tapasztalaton, mindenképpen kell lennie valami velünk született képességnek is. [Chomsky, 1965; Szabó, 2010; Vass, 2006] Ö tekinthető a kognitív forradalom előfutárának, hiszen elméletével szembe ment az akkor elfogadott viselkedés-lélektan, a behaviorizmus alapelveivel. [Csapó, 2002]

A modern kompetencia mozgalom az amerikai oktatáspszichológiában már az 1960-as évek végén, a 70-es évek elején megindult. A kutatók észrevették, hogy a hagyományos tesztek minimális összefüggést mutatnak a munkahelyi sikerességgel és az új kutatások azt igyekeztek feltárni, hogy melyek azok a jellemvonások, kompetenciák, melyek megkülönböztetik a sikeres munkavállalót a sikertelentől. [Spencer, 1997]

Európában az 1990-es években lett felkapott fogalom a kompetencia, ami az előző alfejezetekben részletezett elméletekhez is kapcsolódik. A tanulási eredmények megfogalmazásánál gyakran elökerül a kompetencia fogalma is. [Falus, 2006]

„Egy olyan világban, ahol a tényszerü ismeretek, információk hatalmas tömege mind gyorsabban jön létre, terjed el és válik elérhetővé, az embereknek egyre kevésbé van szükségük arra, hogy az ilyen ismereteket memorizálják. Ehelyett megfelelő eszközökre van szükségük ahhoz, hogy kiválasszák, feldolgozzák és alkalmazzák azt az ismeretanyagot, mellyel sikeresen megbirkózhatnak a foglalkoztatás, a szabadidő és a családi élet változó modelljeivel, mintáival. Ez a felismerés magyarázza azt, az oktatásban megfigyelhető, erősödő tendenciát, hogy a tényszerű ismeretek tanításával szemben a kompetenciák fejlesztése válik egyre inkább hangsúlyossá." [Eurydice, 2002 p. 13.]

Ezzel az a fó probléma, hogy a kompetencia fogalmának nincs egy egységes definíciója, a fogalom értelmezése nem egyértelmü sem a magyar, sem a nemzetközi irodalomban. [Vass, 2006; Mihályi, 2002, 2003]

A kompetencia latin eredetű szó, a Magyar Értelmező Kéziszótár szerint illetékességet, hatáskört jelent. [MTA, 1992] A hétköznapi értelemben alkalmasságot, ügyességet fejez ki. [Vass, 2006] A Pedagógiai Lexikon szerint ,alapvetően értelmi (kognitív) alapú tulajdonság, de fontos szerepet játszanak benne motivációs elemek, képességek, egyéb emocionális tényezők". [Báthory - Falus (szerk.), 1997. p. II. 266.]

Gyakran megkülönböztetik a kompetencia fogalmának két megközelítését, egyrészt az eredet, másrészt az eredmény felől. Az eredet megközelítés azt hangsúlyozza, hogy az 
egyénnek milyen jártasságai, készségei, képességei, motívumai vannak. Az eredményszemlélet a kompetenciát a teljesítményképes tudáshoz köti. [Szabó, 2010.]

A tanulási eredmények megfogalmazásában szereplő kompetenciafogalom az eredményszemléletet tükrözi.

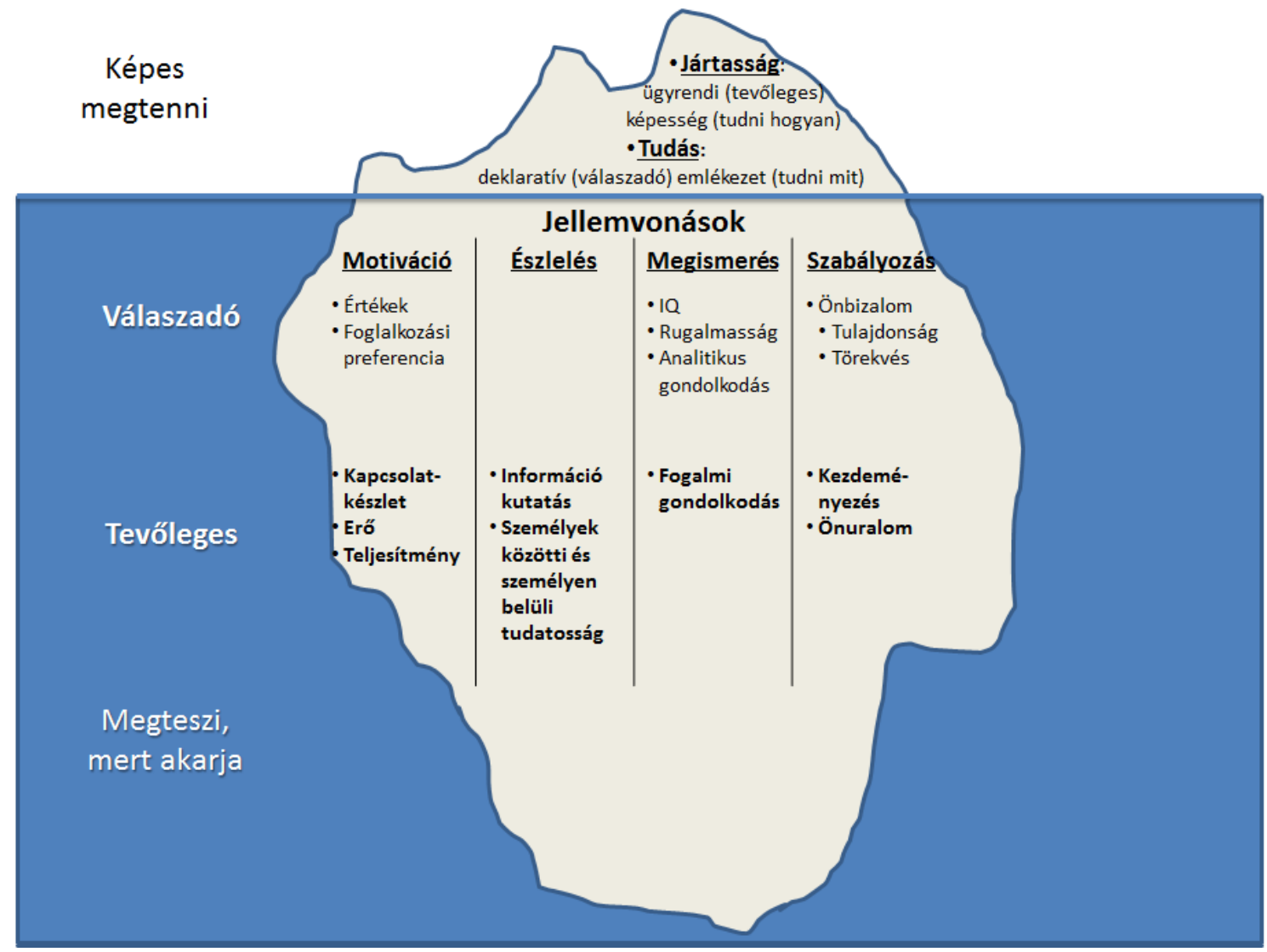

4. ábra: A kompetenciák jéghegymodellje Spencer [1997 p. 8.] alapján (saját szerkesztés, eredetiből fordítva)

A kompetencia fogalmának összetettségét jól jellemzi az úgynevezett jéghegy modell is (4. ábra), amely azt hangsúlyozza, hogy a mérhető, látható, fejleszthető rész csak a jéghegy csúcsa, az alapvető jellemvonások a vízszint alatt találhatóak és sokkal nehezebben taníthatóak. [Spencer, 1997]

Gyakran használják az Európai Tanács szakértője, J. Coolahan által javasolt meghatározást. Szerinte a kompetencia „tudáson, tapasztalaton, értékeken és diszpozíciókon alapuló általános képesség, melyet az egyén oktatási folyamatokban való részvétel útján sajátít el". [idézi: Eurydice, 2002 p. 13.]

Az OECD által indított DeSeCo program (Defining and Selecting Key Competencies 1997-2002) vezetői összefoglalója szerint a kompetencia „több, mint csupán tudás és készségek. Képesség a komplex feladatok megoldására adott kontextusban, támaszkodva 
és mobilizálva az egyén pszichológiai forrásait (köztük a készségeket és attitüdöket is). Például a hatékony kommunikáció képessége egy olyan kompetencia, amely támaszkodik az egyén nyelvtudására, gyakorlati IT képességeire és arra, hogy milyen a hozzáállása a másik félhez, akivel kommunikálni kell.,, [DeSeCo, 2005p.4.]

A számtalan kompetencia-megközelítés közül kiemelném még két közgazdász (Frank Levy és Richard J. Murmane) véleményét, melyet szintén a DeSeCo projekt keretében, annak egyik tanulmányában fejtettek ki. Ök a gazdasági sikerek szempontjából kritikus kompetenciák témájával foglalkoztak. A közgazdasági szakirodalommal egybehangzóan a kompetenciákat és a készségeket szinonim fogalmakként kezelik, de nem csak kognitív készségeket értenek alatta (például állhatatosság). [Mihályi, 2002]

Az Oktatási Hivatal Támop 4.1.3 Felsőoktatás-fejlesztési alprojektben használt definíció: „Egy adott területre, feladatra, feladatcsoportra vonatkozó hatékony, eredményes tevékenység végzését lehetővé tevő pszichikus rendszerek. A kompetenciát általában a tudás/ismeretek, a készségek, képességek és az attitüdök rendszerének tartják, amit néhány leírás még kiegészít az értékek, vagy/és a motívumok, autonómia vagy más fogalommal." [Vámos, 2013 p. 2.]

Ez utóbbi definícióban szerepel néhány olyan fogalom, melyekkel már korábban is találkoztunk, de nem árt tisztázni őket.

Tudás/ismeretek: Az ismeret az eredeti Bloom taxonómia kognitív tartományának első szintje. A tudás ennél bővebb fogalom, általános használata során ismereteket és képességeket is magában foglal. Ennek megfelelően megkülönböztetünk deklaratív és procedurális tudást. Ha a kompetencia fogalmának összetevőjeként beszélünk tudásról, azalatt rendszerint a deklaratív tudást értjük és Bloom taxonómiájának kognitív tartományából az első mellett a második szintet is ide soroljuk (ismeret + megértés).

A dolgozatban a továbbiakban a kompetencia egyik összetevőjeként az ismeret, vagy a deklaratív tudás kifejezést fogom használni. A tudás alatt a deklaratív és procedurális összetevőket is értem, így a kompetencia szinonimájaként fogom használni.

Készségek és képességek: Az előző bekezdésben tárgyalt ismeretekhez, tudáshoz képest ezek cselekvést takarnak, az ismeretek alkalmazását, elemzését, szintetizálását, értékelését. Ezek a cselekvések lehetnek kognitív jellegüek (Bloom taxonómiájának felsőbb szintjei), illetve pszichomotorosak. Az alapvető különbség a készségek és a képességek 
között, hogy a készségek automatizált elemi cselekvések, míg a képességek egy feladat megoldáshoz tudatosan összekapcsolt készségek és ismeretek.

Attitűd: Az attitüd lényege az értékelő viszonyulás valamilyen konkrét vagy elvont tárgy irányába. Sokféle értelmezése és megközelítése van. A napjainkban jellemző többdimenziós megközelítés szerint az affektív összetevő mellett kognitív és konatív (gondolati és viselkedési) összetevők is megjelennek. A tanulási eredmények részeként értelmezve az a probléma, hogy bár megfogalmazható és szükséges, de nagyon nehezen mérhető, és így nem bizonyítható, hogy a tanulók a tanulási folyamat végén valóban elérték-e a kitüzött célokat. A tanulási eredmények megfogalmazásánál gyakran továbbra is az egydimenziós megközelítést használják, és Bloom taxonómiájának affektív tartományszintjeit használják a fokozatok leírásához.

A kompetencia fogalmának a dolgozatban használt struktúráját mutatja a 1. mellékletben szereplő ábra.

A számtalan definíció mellett abban is széles a paletta, hogy mit tekintenek az egyes kutatók, kutatócsoportok, szervezetek kulcskompetenciának, a kompetenciák milyen felosztását alkalmazzák. Az alábbiakban ezek közül mutatok be néhányat, megmutatva a közös és az eltérő gondolatokat.

- A DeSeCo program a kulcskompetenciák három kategóriáját különíti el:

- az autonóm cselekvéssel kapcsolatos kompetenciák

- az eszközök interaktív használatával kapcsolatos kompetenciák

- a szociálisan heterogén környezetben való működéssel kapcsolatos kompetenciák. [DeSeCo, 2005]

- A Tempus Közalapítvány támogatásával, a Szent István Egyetem Gazdaság- és Társadalomtudományi Kar Vezetéstudományi Tanszék munkája 2001-ben 3 kompetenciacsoportot határozott meg, ezek a kulcskompetenciák, a munkakompetenciák és a vezetői kompetenciák. Az 5 kulcskompetencia:

- kommunikáció

- $\quad$ számszerüsítési készség

- csoportmunka

- problémamegoldó készség

- tanulás és teljesítmény fejlesztése [SZIE, 2001] 
- Az Európai Képzési Alapítvány a kompetenciáknak 8 körét határozta meg: elemi, életvezetési, kulcs, szociális és állampolgári, vállalkozói, menedzsment, általános. Ezek közül a kulcskompetencia csoportba az alábbi 6 kompetenciát sorolta:

- kommunikáció (verbális és nonverbális, különböző élethelyzetekhez kötött)

- $\quad$ az információs és kommunikációs technikák alkalmazása

- gyakorlati számítások

- saját tanulásért és teljesítményért, valamint fejlesztésükért viselt felelősség

- problémamegoldás

- másokkal való együttmüködés [Bogár, 2002]

- Az Európa Tanács 2002-es, országokat és képzési rendszereket összehasonlító tanulmányában 3 olyan kulcskompetenciát talált, melyek mind a 4 olyan rendszerben szerepeltek, ahol a kulcskompetenciák szervesen beépültek az oktatástervezésbe (francia Belgium, Anglia és Wales, Skócia, Portugália). Ezen kívül 4 olyan kulcskompetenciát sorol fel, amelyik legalább egy országban explicit megjelenik:

- kommunikáció anyanyelven és idegen nyelven

- együttmüködés (munka másokkal)

- problémamegoldás

- Számolás

- információs és kommunikációs technológia

- tanulni tanulás

- gondoskodás a saját fizikai jólétröl [European Commission, 2002]

- Az Európai Unió alapképességek (basic skills), majd kulcskompetencia (key competence) munkabizottsága 8 kulcskompetenciát értelmezett

- kommunikáció anyanyelven

- kommunikáció idegen nyelven

- matematikai műveltség és alapkompetenciák természettudományos és technológiai téren

- információs és kommunikációs technológiák alkalmazásához kapcsolódó képességek

- a tanulni tanuláshoz kapcsolható készségek és képességek

- a személyközi és állampolgári kompetenciákhoz kapcsolható készségek és képességek

- a vállalkozói szellem elmélyítéséhez kapcsolható készségek és képességek 
- a kulturális tudatosság kialakításához kapcsolható készségek és képességek. [European Union, 2006]

2. táblázat Kulcskompetenciák csoportosításának összehasonlítása

\begin{tabular}{|c|c|c|c|c|}
\hline TEMPUS (2001) & $\begin{array}{c}\text { EURÓPAI } \\
\text { KÉPZÉSI } \\
\text { ALAPÍTVÁNY } \\
(\mathbf{2 0 0 2 )} \\
\end{array}$ & $\begin{array}{c}\text { EURÓPA } \\
\text { TANÁCS (2002) }\end{array}$ & $\begin{array}{c}\text { EU } \\
\text { KULCSKOMPE- } \\
\text { TENCIA } \\
\text { BIZOTTSÁGA } \\
\end{array}$ & $\begin{array}{c}\text { QUÉBEC- } \\
\text { PROGRAM } \\
\text { (2004) }\end{array}$ \\
\hline kommunikáció & kommunikáció & kommunikáció & kommunikáció & kommunikáció \\
\hline $\begin{array}{l}\text { számszerüsítési } \\
\text { készség }\end{array}$ & $\begin{array}{l}\text { gyakorlati } \\
\text { számítások }\end{array}$ & számolás & $\begin{array}{c}\text { matematikai } \\
\text { műveltség és ... }\end{array}$ & \\
\hline csoportmunka & $\begin{array}{l}\text { másokkal való } \\
\text { együttmüködés }\end{array}$ & együttmüködés & & $\begin{array}{l}\text { személyi és } \\
\text { szociális } \\
\text { kompetenciák } \\
\text { (... együtt- } \\
\text { müködés ) }\end{array}$ \\
\hline \multirow[t]{2}{*}{$\begin{array}{l}\text { probléma- } \\
\text { megoldó } \\
\text { készség }\end{array}$} & $\begin{array}{l}\text { probléma- } \\
\text { megoldás }\end{array}$ & $\begin{array}{l}\text { probléma- } \\
\text { megoldás }\end{array}$ & & $\begin{array}{l}\text { intellektuális } \\
\text { kompetenciák } \\
\text { (... probléma- } \\
\text { megoldás, ...) }\end{array}$ \\
\hline & $\begin{array}{l}\text { információs és } \\
\text { kommunikációs } \\
\text { technikák }\end{array}$ & $\begin{array}{l}\text { információs és } \\
\text { kommunikációs } \\
\text { technológia }\end{array}$ & $\begin{array}{l}\text { információs és } \\
\text { kommunikációs } \\
\text { technológiák }\end{array}$ & $\begin{array}{l}\text { módszertani } \\
\text { kompetenciák } \\
\text { (információs és } \\
\text { kommunikációs } \\
\text { technológiák) }\end{array}$ \\
\hline $\begin{array}{l}\text { tanulás és } \\
\text { teljesítmény } \\
\text { fejlesztése }\end{array}$ & $\begin{array}{l}\text { saját tanulásért } \\
\text { és } \\
\text { teljesítményért, } \\
\text { valamint } \\
\text { fejlesztésükért } \\
\text { viselt felelősség }\end{array}$ & tanulni tanulás & $\begin{array}{l}\text { a tanulni } \\
\text { tanuláshoz } \\
\text { kapcsolható } \\
\text { készségek és } \\
\text { képességek }\end{array}$ & \\
\hline
\end{tabular}

- A Québec-program kilenc kereszttantervi kompetenciát négy kategória szerint sorol be:

- intellektuális kompetenciák (információhasználat, problémamegoldás, kritikai gondolkodás, kreativitás)

- módszertani kompetenciák (hatékony munkamódszerek alkalmazása, információs és kommunikációs technológiák)

- $\quad$ személyi és szociális kompetenciák (identitás, együttműködés másokkal)

- $\quad$ kommunikáció [Ranschburg, 2004] 
A fenti kompetenciacsoportosításokat táblázatba foglalva láthatjuk, hogy elég sok közös vonás van bennük, és majdnem mindegyikben szerepel az információs és kommunikációs technológiák alkalmazása valamilyen módon. A 2. táblázat a fenti 5 csoportosítás közös elemeit mutatja.

\section{III.2. A bolognai folyamat Európában}

Az előző fejezetben bemutatott pedagógiai elméletek egyre nagyobb szerephez jutnak az európai felsőoktatás átalakulásában. Az 1999-ben Bolognában elkezdődött és azóta is tartó folyamat Európa minden országában, így hazánkban is befolyásolja az intézmények müködését, szabályozását, az oktatás tartalmát. A következőkben összefoglalom a Bolognában és az azóta történteket elsősorban az értekezés témáját tartva szem előtt (3. táblázat).

\section{III.2.1. Kezdetek}

Az 1999-es Bolognai nyilatkozat, egy évvel a Sorbonne megnyitásának 800. évfordulója után a Közös Európai Felsőoktatási Térség (European Higher Education Area, EHEA) kialakítását tüzte ki célul, és ezáltal az európai felsőoktatás versenyképességének növelését. [European Commission, 2009 ]

A Bolognai Nyilatkozat és az azt követő újabb találkozók nyomán előállt főbb pontok a következőképpen foglalhatók össze:[Kennedy, 2007; EHEA, 1999; EHEA, 2001]

- Az Európai Felsőoktatási Térség (továbbiakban EFT) révén az európai felsőoktatás nemzetközi versenyképessége javul.

- A képesítések és a képesítési struktúrák hagyományos módszerek segítségével történő leírását fejleszteni kell, ezen leírásokat pedig még átláthatóbbá kell tenni. Olyan rendszert kell bevezetni, amely a diplomák egyszerü értelmezését és összehasonlíthatóságát teszi lehetővé.

- Minden végzett hallgató automatikusan és térítésmentesen egy széles körben beszélt európai nyelven íródott oklevélmellékletet kap. Az oklevélmelléklet a hallgató által megszerzett képesítést részletezi olyan szabványformátumban, amelyet egyszerủen meg lehet érteni, és más diplomákkal össze lehet hasonlítani. A melléklet kitér a képesítés tartalmára és azon felsőoktatási rendszer struktúrájának leírására, amelyben az adott diplomát kiállították. Az oklevélmelléklet célja, hogy növelje az átláthatóságot, és hogy a diplomák elismerését elősegítse. 
DOI: 10.14267/phd.2014081

3. táblázat A bolognai folyamat összefoglalása 1998-tól 2009-ig [EHEA, 2012b p. 15]

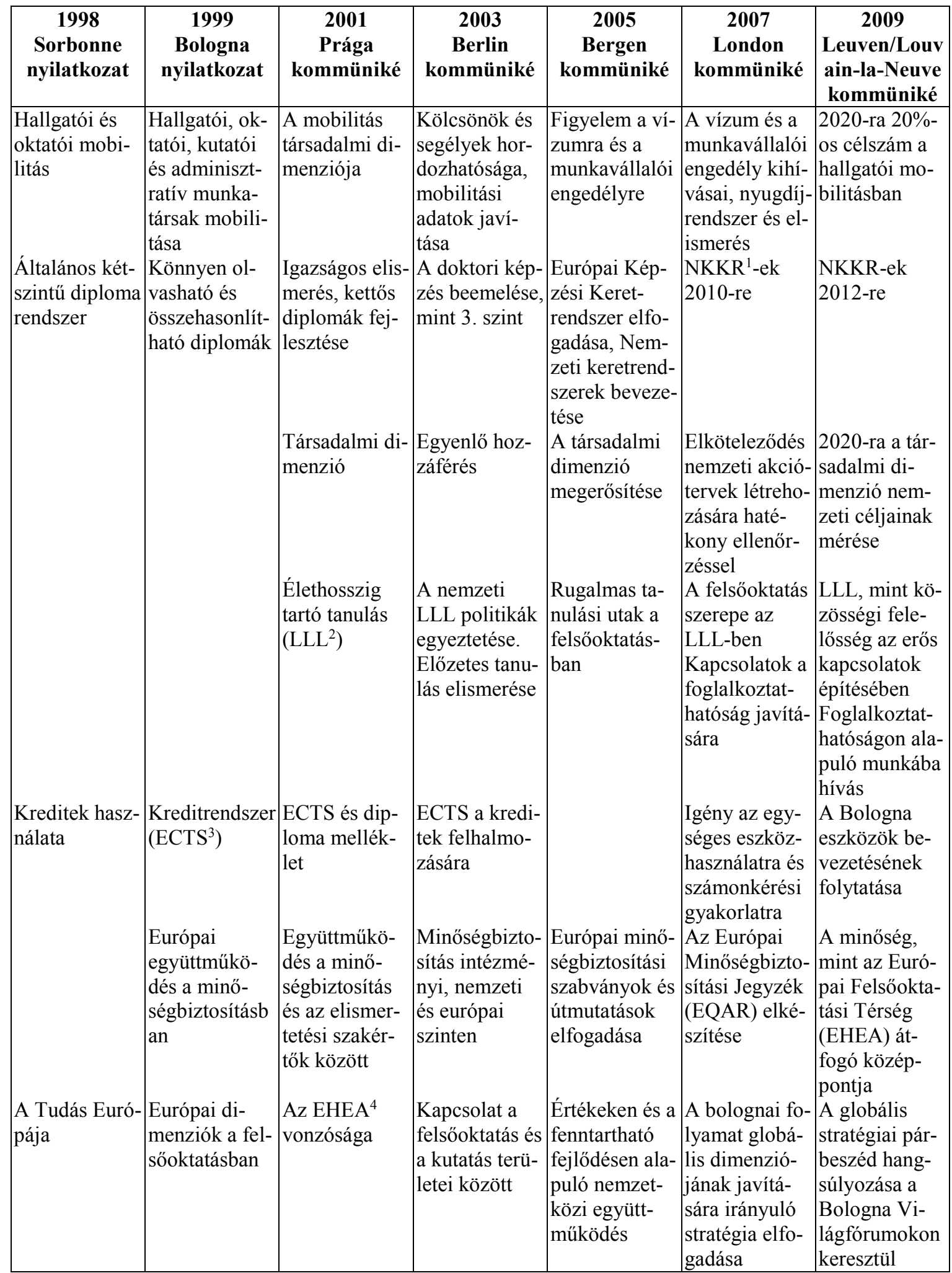

\footnotetext{
${ }^{1}$ Nemzeti Képesítési Keretrendszer

${ }^{2}$ Life Long Learning - Egész életen át tartó tanulás

${ }^{3}$ European Credit Transfer and Accumulation System

${ }^{4}$ European Higher Education Area
} 
- A felsőfokú tanulmányok két ciklusban valósulnak meg: az első ciklus legalább hároméves időtartamú tanulmányokat takar (ez jelenleg minimum 180 kreditmegszerzését jelenti), a második ciklus pedig a mesterképzésben és/vagy a doktori képzésben való részvételt jelenti. Ezt a későbbiekben úgy módosították, hogy a doktori képzés egy külön, harmadik ciklusként kapjon helyet a bolognai folyamatban, valamint hogy a doktori képzés révén szorosabb kapcsolat alakuljon ki az EFT és az Európai Kutatási Térség (EKT) között.

- Bevezetésre kerül a felsőfokú tanulmányok során szerezhető kreditek átvitelét lehetővé tevő és a hallgatói mobilitást elősegítő rendszer, amely az EFT-n belül elhárítja a diplomák jogi elismerésével kapcsolatos és egyéb adminisztrációs akadályokat.

- A felsőfokú tanulmányi kreditek átvitelét lehetővé tevő rendszer elősegíti a minőségbiztosítás terén az európai szintű együttműködést.

- A felsőoktatási intézmények és azok hallgatóinak - mint a bolognai folyamat alapvető partnereinek - helyzete megszilárdul.

- A felsőoktatás európai dimenziója a hallgatók, oktatók és kutatók számára nyitva álló intézményközi együttmüködések, képzési programok és mobilitási projektek formájában valósul meg.

A Bolognában megrendezett találkozót követően a folyamat megvalósulásának elősegítése céljából számos újabb miniszteri találkozót tartottak. Ezen találkozók helyszínei az alábbi városok voltak: Prága (2001), Berlin (2003), Bergen (2005), London (2007), Leuven és Louvain-la-Neuve (2009), Budapest és Bécs (2010) és Bukarest (2012). Minden találkozót követően kommünikét adtak ki.

A 2003-as berlini kommünikéből származó alábbi idézet megmutatja, hogy a bolognai folyamat az előző alfejezetekben részletezett pedagógiai megfontolásokat szeretné beemelni az Európai Felsőoktatási Térség gyakorlatába:

„A miniszterek arra ösztönzik a tagállamokat, hogy felsőoktatási rendszereik tekintetében olyan keretrendszert alakítsanak ki, amely révén lehetővé válik a diplomák összehasonlítása és egymásnak való megfeleltetése, és amely a diplomákat a befektetett munka, az oktatás szintje, a tanulási eredmények,kompetenciák és profil szerint írja le. Megállapodnak abban is, hogy az Európai Felsőoktatási Térség vonatkozásában megkezdik egyegységes képesítési keretrendszer kialakítását.”[EHEA,2003 p. 4.] 


\section{III.2.2. Megalakul az Európai Felsőoktatási Térség}

Az Európai Felsőoktatási Térség hivatalos megalakulása a 2010-es miniszteri találkozón történt meg, amelyet Budapesten és Bécsben tartottak. [EHEA, 2010] Nem valósult még meg ugyan minden kezdeményezés, amit Bolognában célul túztek ki, de a bolognai folyamat egy új fázisba lépett ezzel a lépéssel. [European Commission, 2009a]

A 2012-es Bukaresti Miniszteri Konferencia a globális gazdasági válságra válaszképpen 3 fókuszterületet tűzött ki. Ezek: minőségi felsőoktatás biztosítása minél több hallgató számára, a hallgatók felvértezése a munkaerőpiacon minél inkább alkalmazható készségekkel és a hallgatói mobilitás növelése. [EHEA, 2012 $]$

„A mai diplomásoknak kombinálniuk kell több tudományágat átfogó és innovációs készségeiket és kompetenciáikat a naprakész tárgyspecifikus ismeretekkel, hogy hozzá tudjanak járulni a társadalom és a munkaerőpiac szélesebb igényeihez. Célunk fokozni a diplomások alkalmazhatóságát és a személyes és szakmai fejlődését végig a karrierjük során. Ezt úgy érhetjük el, hogy javítjuk az együttmüködést az alkalmazók, a hallgatók és a felsőoktatási intézmények között, különösen az oktatási programok fejlesztésében, ami segíteni fog a diplomások innovatív, vállalkozói és kutatói potenciáljának növelésében."[EHEA, 2012 a p. 2.]

\section{III.2.3. Tuning projekt}

A bolognai folyamathoz kapcsolódó Tuning projekt (Tuning Educational Structures in Europe) egy egyetemek által életre hívott kezdeményezés és onnan kapta a nevét, hogy nem a képzések egységesítése a feladata, csak azok összehangolása (tuning = hangolás, angol). Nagyon hangsúlyos, hogy az Európai sokszínüség megmaradjon, nem akarják az egyetemek autonómiáját megsérteni, csak támpontokat kívánnak nyújtani a képzések öszszehangolásához képzési területenként.[González - Wagenaar, 2008]

A tantervek készítésekor fontos megtalálni az egyensúlyt az integráció és a differenciálás között. A különböző intézmények ugyanazt nyújtják az egyes képzések keretében, de ugyanakkor egyedi vonásokat is belevihetnek a tantervbe. [Perjés - Vass, 2009; Szebenyi, 1994] Akármennyire igény van a közös európai terminológia és folyamatok adaptálására a képzések leírásában, ez nem jelentheti azt, hogy a tartalmakat, célokat és szervezeteket standardizáljuk. [Ministry of Science, Technology and Innovation, 2005] 
A kompetenciák egy része kötött az adott képzési területhez, másik részük általános, minden kurzushoz kapcsolódik. A Tuning program kapcsán Európa szerte egy konzultációs folyamatot indítottak el, amelyben részt vesznek a munkáltatók, a végzettek és az akadémiai szereplők. Ennek keretében próbálták az általános kompetenciák fontossági sorrendjét megállapítani. A Tuning 1 felméréshez képest változtattak a kompetencialistán, ami a végleges kérdőívben a következő 30 elemet tartalmazta [González - Wagenaar, 2008]:

- Eszköz-jellegü kompetenciák (instrumental):

○ elemzés és összefoglalás

○ szervezés és tervezés

○ általános alaptudás

○ megalapozott szakmai alaptudás

- szóbeli és írásbeli kommunikáció az anyanyelven

○ második nyelv ismerete

○ alapvető számítástechnikai készségek

○ információmenedzsment

○ problémamegoldás

○ döntéshozatal

- Interperszonális kompetenciák

○ kritikus és önkritikus képességek

o csapatmunka

○ kapcsolatteremtési képesség

○ munka egy komplex csapatban

○ kommunikáció más szakterületek szakembereivel

○ a különbözőség és a multikulturális környezet elismerése

○ munka nemzetközi kontextusban

○ etikai elkötelezettség

- Rendszerező kompetenciák

○ a tudás gyakorlatban való alkalmazása

○ kutatói képesség

○ tanulási képesség

○ alkalmazkodás új helyzetekhez

○ új ötletek létrehozása, kreativitás

○ vezetői képesség (leadership) 
○ más országok kultúrájának és szokásainak megértése

○ önálló munkavégzés

○ projekt tervezés és vezetés

○ kezdeményező és vállalkozói szellem

○ minőség iránti elkötelezettség

○ hajlandóság a sikerre

A fenti 30-ból 17-et soroltak be mind az akadémiai szereplők, mind a munkaadók és a végzettek. Ezek összehasonlító rangsorát tartalmazza a 4. táblázat, a végzettek és a munkáltatók közös rangsorának sorrendjében.

4. táblázat Kompetenciák fontossági rangsora az egyes érintettek szerint (Forrás: González Wagenaar, 2008 pp. 46-47.)

\begin{tabular}{|l|c|c|c|c|}
\hline \multicolumn{1}{|c|}{ Kompetencia megnevezése } & $\begin{array}{c}\text { akadémiai } \\
\text { szereplök }\end{array}$ & $\begin{array}{c}\text { végzet- } \\
\text { tek }\end{array}$ & $\begin{array}{c}\text { munkál- } \\
\text { tatók }\end{array}$ & $\begin{array}{c}\text { végzettek és } \\
\text { munkáltatók } \\
\text { közös } \\
\text { rangsora }\end{array}$ \\
\hline elemzés és összefoglalás & 2 & 1 & 3 & 1 \\
\hline tanulási képesség & 3 & 2 & 1 & 2 \\
\hline $\begin{array}{l}\text { a tudás gyakorlatban való } \\
\text { alkalmazása }\end{array}$ & 5 & 3 & 2 & 3 \\
\hline alkalmazkodás új helyzetekhez & 7 & 5 & 4 & 4 \\
\hline $\begin{array}{l}\text { szóbeli és írásbeli kommunikáció az } \\
\text { anyanyelven }\end{array}$ & 9 & 7 & 7 & 5 \\
\hline személyközi készségek & 14 & 6 & 5 & 6 \\
\hline új ötletek létrehozása, kreativitás & 4 & 9 & 6 & 7 \\
\hline $\begin{array}{l}\text { alapvetó számítástechnikai } \\
\text { készségek }\end{array}$ & 16 & 4 & 10 & 8 \\
\hline döntéshozatal & 12 & 8 & 8 & 9 \\
\hline kritikus és önkritikus képességek & 6 & 10 & 9 & 10 \\
\hline munka egy komplex csapatban & 10 & 13 & 11 & 11 \\
\hline általános alaptudás & 1 & 12 & 12 & 12 \\
\hline megalapozott szakmai alaptudás & 8 & 11 & 14 & 13 \\
\hline etikai elkötelezettség & 13 & 16 & 13 & 14 \\
\hline második nyelv ismerete & 15 & 14 & 15 & 15 \\
\hline kutatói képességek & 11 & 15 & 17 & 16 \\
\hline $\begin{array}{l}\text { a különbözóség és a multikulturális } \\
\text { környezet elismerése }\end{array}$ & 17 & 17 & 16 & 17 \\
\hline & & & & \\
\hline
\end{tabular}

Látható, hogy a végzettek és a munkáltatók rangsora jobban hasonlít egymáshoz, mint az egyetemi oktatók rangsora bármelyikükhöz. Néhány szembetűnő eltérést emelnék ki: 
- az akadémiai szereplők rangsorában jóval hátrébb szerepelnek a személyközi kérdések, és ami számunkra különösen érdekes, az alapvető számítástechnikai készségek. Utóbbi kompetencia a végzettek és munkáltatók közös rangsorában a 8. (a végzettekében a 4.), míg a professzorok rangsorában az utolsó előtti.

- Az oktatók rangsorában legelső általános alaptudás a másik két csoport szerint a hátsó középmezőnyben van, 12.

- Az oktatók által a középre sorolt megalapozott szakmai alaptudás és a kutatói képességek a másik két csoport rangsorában jóval hátrébb, a 13. illetve a 16. helyen találhatóak. [González - Wagenaar, 2008]

A felmérést megismételték 2008-ban kicsit módosított és kibővített kompetencialistával, és a megkérdezettek körének kibővítésével. A 31 kompetenciát az oktatóknak, a végzetteknek a munkáltatóknak és új csoportként a hallgatóknak is be kellett sorolniuk. A számunkra érdekes számítógépes ismeretek itt már kisebb eltérést mutattak: az oktatók és a hallgatók a 19., a végzettek a 20. és a munkáltatók a 23. helyre sorolták.

Az új felmérésben az első 4 helyezett minimális eltérésekkel megegyezik a 4 csoport körében: absztrakt gondolkodás, elemzés és összefoglalás képessége; a tudás gyakorlatban való alkalmazása; a szakterület ismerete és a szakma megértése; probléma felismerése, felvetése és megoldása. Az utolsó 4 helyezettnél kicsit nagyobb eltérések mutatkoznak. Fordított sorrendben: tudatos törekvés az esélyegyenlőségre; biztonság iránti elkötelezettség (munkáltatóknál a 25.); vállalkozói, innovatív szellem (munkáltatóknál a 17.); környezetvédelem iránti elkötelezettség; kommunikáció az adott szakterülethez képest kívülállókkal; a különbözőség és a multikulturális környezet elismerése; munka nemzetközi környezetben (a munkáltatóknál 28., a többieknél 21-23.). [Tuning, 2009]

A Tuning megközelítés sikerét mutatja, hogy több kontinensen tesztelték és nemzetközi legitimációt kapott. Már több mint 30 képzési területen alkalmazzák, több intézményben Európában, Latin Amerikában és néhány ázsiai országban is. Néhány USA államban is tesztelik. [OECD, 2011]

\section{III.2.4. A bolognai folyamat megvalósítása Magyarországon és Európában}

A 2012-es jelentés a bolognai folyamat megvalósulásáról 2011 első félévében gyüjtött adatokra támaszkodik és rendkívül széleskörü. Ennek fő megállapítása, hogy a bolognai folyamat egy európai sikertörténet, az első 10 évben valóban markáns pozitív változások történtek az európai felsőoktatásban. 
Mind a 47 országban megvalósult az idegen nyelven is kiadott közérthető diploma illetve a 3 ciklusú képzés bevezetése, de több országban ez még nem általános (5. ábra).

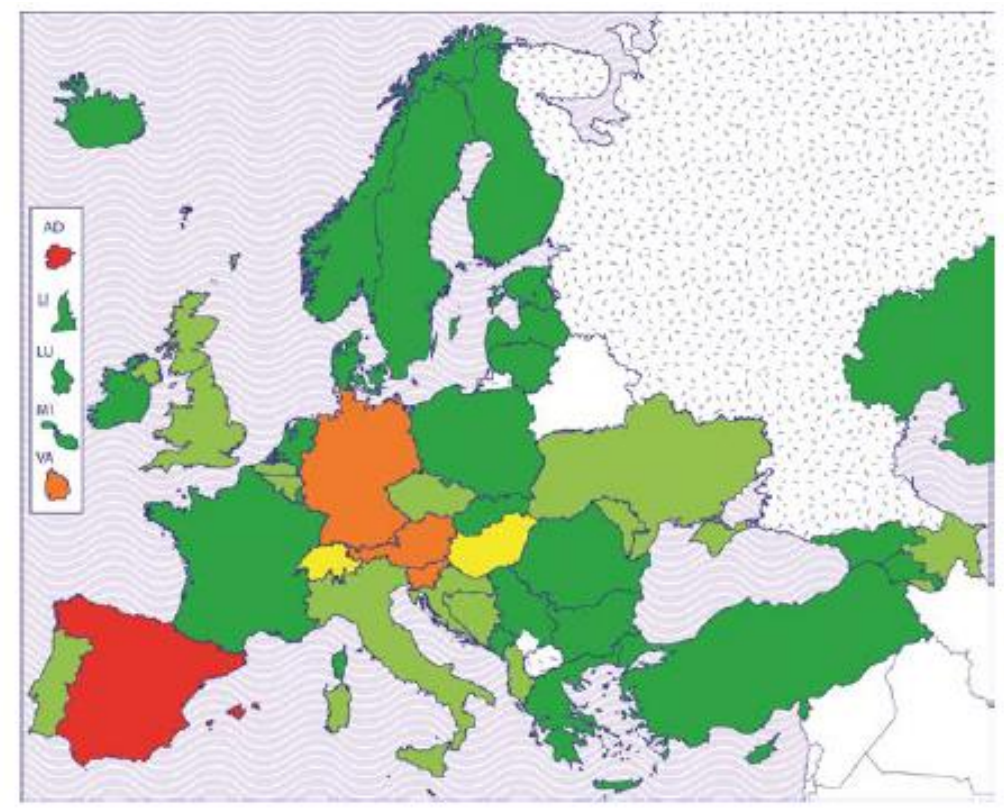

Az összes hallgató legalább 90\%-a a Bologna alapelveknek megfelelố 2 ciklusú rendszerben tanul

A hallgatók 70-89\%-a tanul a Bologna alapelveknek megfelelố 2 ciklusú rendszerben

A hallgatók 50-69\%-a tanul a Bologna alapelveknek megfelelố 2 ciklusú rendszerben

A hallgatók 25-49\%-a tanul a Bologna alapelveknek megfelelố 2 ciklusú rendszerben

A hallgatók kevesebb, mint 25\%-a tanul a Bologna alapelveknek megfelelố 2 ciklusú rendszerben vagy a Bologna alapelveket már elfogadták, de még nem valósították meg

\section{5. ábra A kétciklusú képzés bevezetésének állapota 2010/11-ben [European Commission, 2012}

$$
\text { p. 32.] }
$$

Az országok többségében az első ciklust végzetteknek 10-24\%-a megy tovább rögtön a második ciklusra, de 13 országban ez az arány 75-100\%, ami azt jelenti, hogy ezekben az országokban az alapképzés nem ad valódi munkaképes diplomát, illetve, hogy a munkáltatók még nem fogadják el az alapfokú diplomákat (6. ábra).[European Commission, 2012]

A kétciklusú képzés bevezetése egy egyszerü lépés volt sok országban a valódi reformok helyett. A tanulási eredmények használata sokhelyütt egyelőre csak üres frázis. Még mindig nagy figyelmet kell szentelni annak, hogy a közös kreditrendszer két alappillérét,a hallgatói munkabefektetést és a tanulási eredményeket helyesen értelmezzék. [EUA, 2007] 


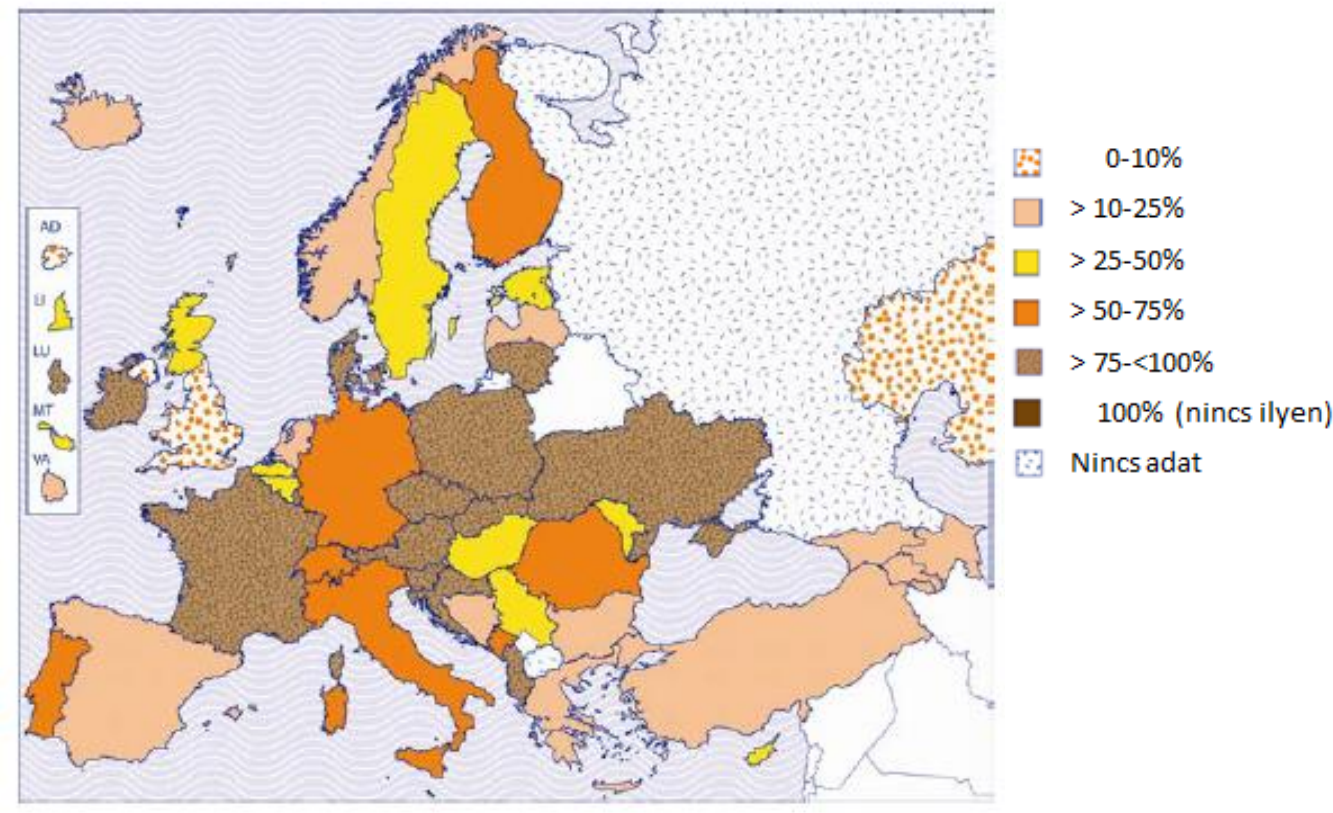

6. ábra Az első ciklus befejezése után két éven belül a második ciklusba lépők aránya2010/11-ben [European Commission, 2012 p. 39.]

A tanulási eredmények használata lett a legfontosabb építőköve az Európai Felsőoktatási Térségnek, holott ezt 1999-ben Bolognában még nem ismerték fel és még a 2001-es prágai kommünikében sem szerepelt, azóta azonban utalnak rá, foglalkoznak vele minden egyes dokumentumban. A bolognai elvek megvalósítási üteme nem egységes Európában, a tanulási eredmények használata a képzések leírásában a különböző országokban eltérő mértékben valósul meg. [Adams, 2008]

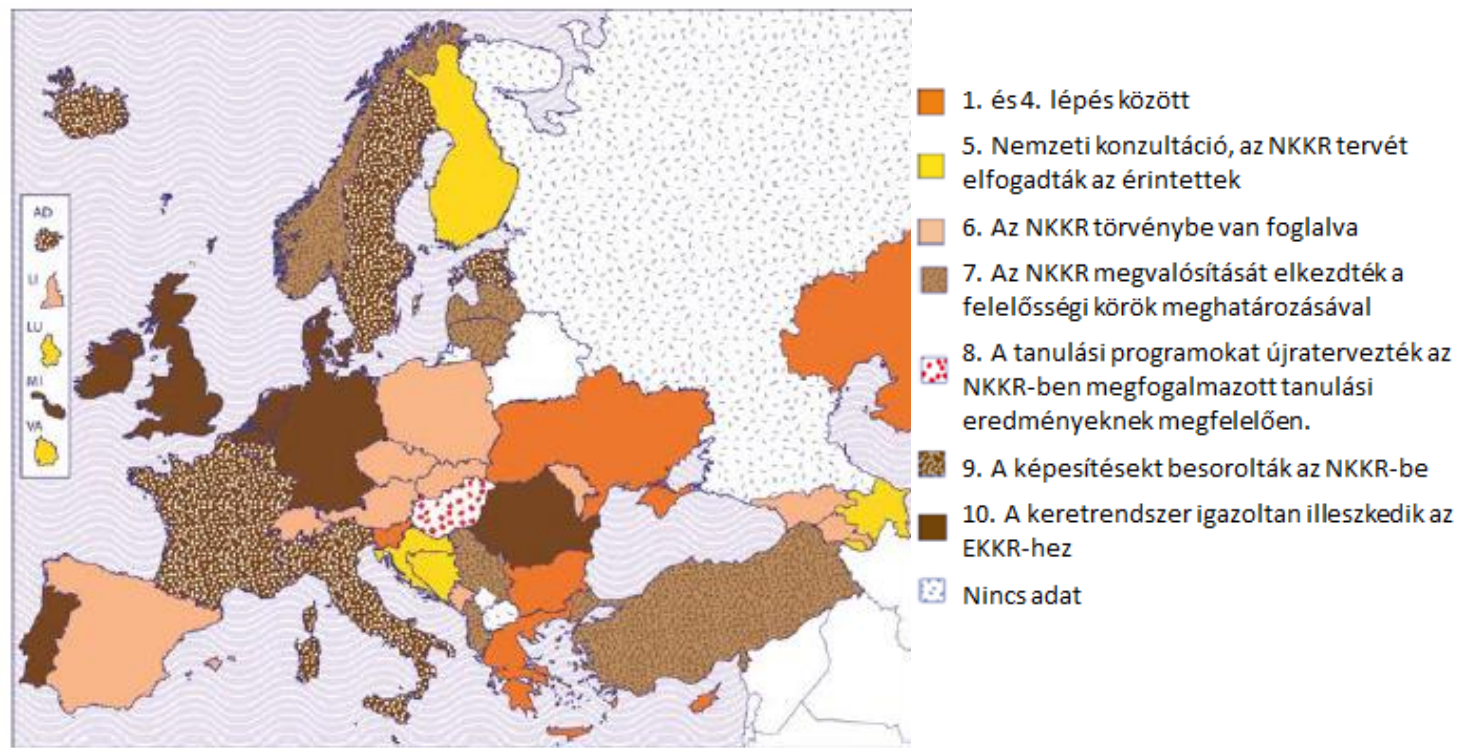

7. ábra A nemzeti képzési keretrendszerek (NKKR) fejlesztésének haladása 2010/11-ben [European Commission, 2012 p. 46.] 
A képzési keretrendszer 9 országban készült el teljesen és még néhány ország nagyon közel áll a készhez (7. ábra). Ezekben az országokban sincsenek azonban összekapcsolva a tanulmányi eredmények a mérési módszerekkel.

Több országnak még sok teendője van ezen a területen, amire a határidőt az eredeti 2010ről 2012-re tolták ki, de ezt is csak kevesen tudták teljesíteni. Ha el is készülnek a nemzeti keretrendszerek, marad még munka az elkövetkező évekre: a képzési keretrendszereket a gyakorlatba is át kell ültetni, ami még nehezebb, mint megalkotni őket.[European Commission, 2012]

Magyarországon a1229/2012. (VII. 6.) Korm. határozat szerint a korábban Országos Képesítési Keretrendszer elnevezés helyett a Magyar Képesítési Keretrendszer elnevezés (MKKR) használandó. [Kormány határozat, 2012]

A hátralévő folyamatok a következő határidőkkel szerepeltek a határozatban:

- Az EKKR elveinek és szerkezetének összhangja az MKKR szintjeivel és az egyes szintek leíró jellemzőivel: 2013. október 30.

- Javaslat a magyar képesítések besorolásáról az MKKR szintjeinek megfelelően, valamint javaslat előkészítése az MKKR-nek az Európai Képesítési Keretrendszer szintjeivel történő megfeleltetésére: 2013. október 30.

- Az MKKR szintjeinek az EKKR szintjeivel való megfeleltetéséről szóló európai uniós jelentés elkészítése, benyújtása: 2013. november 30 .

A határozat többszöri módosításának megfelelően az első két pont módosított határideje 2014. június 30. volt, be is ment a kormány elé egy jelentés. Az utolsó pont aktuális határideje 2014. december 31. [Derényi András közlése alapján]

Az MKKR szintjeinek leírása az 2. mellékletben tekinthető meg. Ebben az egyes szinteket 4 deskriptor mentén írták le. Ezek a kompetencia fejezetben tárgyalt tudás, képesség és attitűd, kiegészítve egy negyedikkel: autonómia és felelősségvállalás.

A közelmúltban jelent meg interjú Loboda Zoltánnal, az Oktatási Hivatal Nemzetközi Osztályának vezetőjével és Derényi Andrással, a felsőoktatási alprojekt vezetőjével az EduPress Híradó számára. Derényi András jól összefoglalja az itthoni helyzetet a tanulási eredményeken alapuló szemléletmóddal kapcsolatban:

„Habár kulturálisan idegen a kimeneti követelmények alapú megközelítés a hazai oktatási szektorban, főként mégis a tudáshiány játszik szerepet abban, hogy nehezen fogadják el 
itthon. Ezek új eszközök, új fogalmak. Gyakran összekeverik a tanulási eredményeket a tanulmányi eredményekkel, illetve nagyon rosszul alakul a kompetencia fogalmának megértése és elfogadása is. Hozzáteszem azért: az angolszász országokban is 15 év kellett ahhoz, hogy kialakuljon a rendszer - nálunk ez még több időt vesz majd igénybe. Tanulási eredményekre irányuló, azaz kellő szinten való felkészítettséget, elért eredményeket értékelő módszereket eddig nem fogalmazták meg, nem építették bele az oktatásba és nem is tanítottak sehol. Úgy gondolom, jelentős oktatási reform zajlik a szemünk előtt." [Edupress, 2013 $]$

Az Európai Kreditátviteli Rendszer (ECTS) bevezetése teljesnek tekinthető Európában, mint átviteli és felhalmozási rendszer. Ugyanakkor a kreditek nincsenek mindenütt öszszekapcsolva a tanulási eredményekkel. Ebben a tekintetben sajnos nem tartozunk az élmezőnybe, 34 ország előz meg bennünket a 47-ből (8. ábra), a lemaradásunk pedig abból adódik, hogy nálunk egyáltalán nincsenek a kreditek a tanulási eredményekhez kapcsolva. Ez rajtunk kívül csak Szlovákiában és Albániában van így.[European Commission, 2012]

A lemaradásunk azért is érdekes, mert 2004-ben a tanulási eredmények használatában még az élen jártunk, a legkidolgozottabb rendszerek a következő országokban müködtek: Dánia, Magyarország, Írország, Olaszország, Szlovákia, Spanyolország, Svédország, Egyesült Királyság, és Belgium (Flandria) [Adam - 2004]

Különbség mutatkozik az országok között abban is, hogy mi alapján rendelnek krediteket egyes képzési elemekhez. Az egyik véglet, hogy csak a kontakt órák alapján (ez egyik országban sem jellemző), vagy csak a hallgatói munkabefektetés alapján. A tendencia az, hogy a krediteket a hallgatói munkabefektetés és a tanulási eredmények alapján állapítják meg. A legtöbb országban 1 kredit 25 és 30 óra közötti hallgatói munkát jelent. [European Commission, 2012]

Azt azonban nehéz meghatározni, hogy mit számítsunk bele a hallgatói munkaórába. Egy akadémiai félév 20 hét, 30 kredit, az kreditenként 30 órával számolva heti 45 óra munka a szorgalmi és a vizsgaidőszakban is. Viszonylag kevés és nem reprezentatív felmérés szól a valódi munkafelhasználásról.

${ }^{5}$ http://www.edupress.hu/hirek/index.php?pid=egycikk\&HirID=28904 utolsó megtekintés: 2013. 08. 28. 


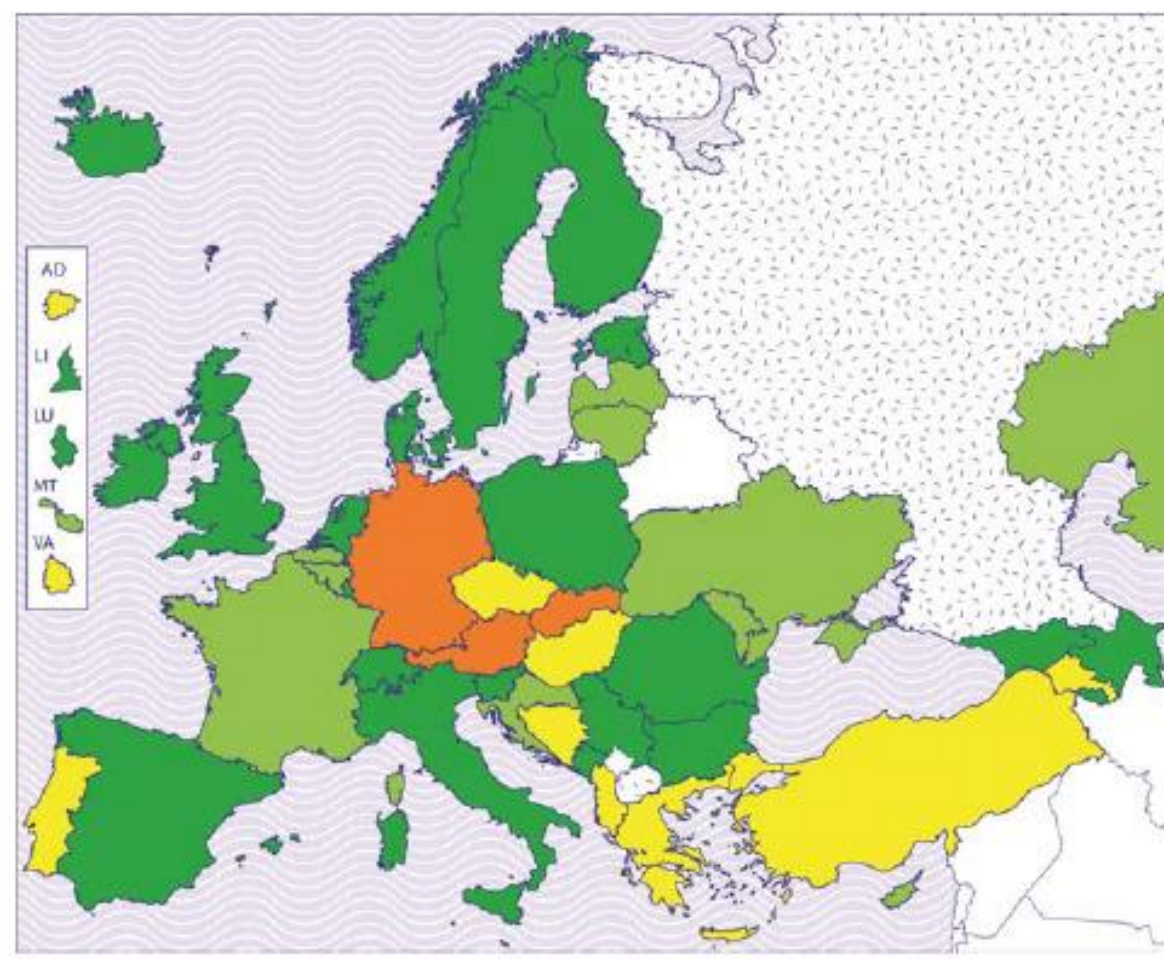

- Az ECTS kreditek minden felsőokatási programhoz hozzá vannak rendelve, alkalmasak az átvitelre és a felhalmozásra és kimutathatóan a tanulási eredményekhez vannak kapcsolva.

- Az ECTS kreditek a felsőoktatási programok több, mint 75\%-ához hozzá vannak rendelve, alkalmasak az átvitelre és a felhalmozásra és kimutathatóan a tanulási eredményekhez vannak kapcsolva VAGY

az ECTS-sel kompatibilis kreditek minden felsőokatási programhoz hozzá vannak rendelve, alkalmasak az átvitelre és a felhalmozásra és kimutathatóan a tanulási eredményekhez vannak kapcsolva.

— Az ECTS kreditkek a felsőoktatási programok 50-75\%-ához hozzá vannak rendelve és kimutathatóan a tanulási eredményekhez vannak kapcsolva VAGY

Az ECTS kreditek a felsőoktatási programok több, mint 75\%-ához hozzá vannak rendelve, alkalmasak az átvitelre és a felhalmozásra, de nincsenek a tanulási eredményekhez kapcsolva.

- Az ECTS kreditek a felsőoktatások legalább 49\%-ához hozzá vannak rendelve VAGY egy nemzeti kreditrendszert használnak, ami nem telejsen kompatibils az ECTS-sel

- Az ECTS kreditek a felsőoktatási programok kevesebb, mint 49\%-ához vannak hozzárendelve VAGY a krediteket minden programhoz használják, de csak kreditátvitelre.

\section{8. ábra A kreditrendszer bevezetésének szintje 2010/11-ben [European Commission, 2012 p. 47.$]$}

Egy ilyen vizsgálat azt mutatta, hogy a valódi kreditérték kb. 25 óra munkát jelent. Ha beleszámolunk minden időt, amit a hallgató a fejlődése érdekében „elhasznál”: technikai idők, úgy mint várakozás, helyváltoztatás, informális, egy-egy tárgyhoz nem kötődő idők, kapcsolatépítés, akkor valószínűleg ennél jóval több idő jön ki. A heti munkaidő nem egyenletes, szorgalmi időszakban van, hogy csak heti maximum 20 óra, vizsgaidőszakban, esszéleadásokkor a heti 80 óra sem elképzelhetetlen. 
A vizsgálat azt is mutatta, hogy modulokra lebontva vannak modulok, amikre a kreditben meghatározottnál többet fordítanak a hallgatók, és vannak, amelyekre cserébe kevesebbet. Ebben a kevés szereplős felmérésben az informatika is ez utóbbi csoportba tartozott. [Tuning, 2009]

A Budapesti Corvinus Egyetemen rendszeresen folytatott hallgatói véleményezés felmérések is azt mutatják, hogy az informatikára fordított hallgatói munkaóra a kreditben meghatározottnál kevesebb (Kováts Gergely, a Budapesti Corvinus Egyetem Minőségügyi titkárának közlése alapján).

A részletesebb magyarországi viszonyokról jó áttekintést nyújtanak a Tempus közalapítvány gondozásában megjelent Bologna füzetek. A 2. és 6. füzet néhány érdekes eredményét szeretném kiemelni. [Fischer-Halász, 2009; Vámos, 2010]

Magyarországon a képzési programjának akkreditálását kérő intézménynek be kell mutatnia, hogy a képzésben elsajátítandó kompetenciákról előzetesen kikérte a szakmai szervezetek, munkaadók és a képzésben érdekelt ágazati minisztérium előzetes véleményét.

A programok képzési és kimeneti követelményeinek leírását a az oktatási miniszter 15/2006. (IV. 3.) sz. rendelete az alap- és mesterképzési szakok képzési és kimeneti követelményeiről melléklete tartalmazza. „E leírások témánk szempontjából egyik fontos jellemezője az, hogy nincs mögöttük koherens, az összes szakterület által közösen elfogadott kompetencia-definíció, így a tanulási eredmények meghatározását tekintve meglehetősen eklektikus és inhomogén. A kompetenciák meghatározásában eltérő logika jellemzi az alap- és a mesterszintű követelmények meghatározását, és egy harmadik logika jelenik meg a tanárképzés területén.

Az alapképzés esetében az egyes szakterületek »az alapképzési szak képzési célja, az elsajátítandó szakmai kompetenciák« összefoglaló cím alatt határozták meg a kompetenciakövetelményeket úgy, hogy ezen belül általában az alábbi három kategória jelent meg, de ezek nem minden esetben hasonlóak.

Így a leggyakoribb az a meghatározás, hogy az alapfokozat birtokában az adott szakemberek (1) »képesek...«, (2) »rendelkeznek...« és (3) »alkalmasak...« valamire vagy valamivel. Előfordul azonban az is, hogy az alapfokozat birtokában az adott szakemberek (1) »ismerik...«, (2) »képesek...«, és (3) »alkalmasak...«valamire vagy valamit, és az 
is, hogy bizonyos általános kompetenciák felsorolását követően jelenik meg annak definiálása, hogy az adott képzettség birtokában a szakemberek mire »képesek« és mire »alkalmasak «. [Fischer - Halász, 2009 p. 11]

A MAB-nak az alapszakok létesítésére irányuló kérelmek összeállításához kiadott útmutatója az elsajátítandó szakmai kompetenciák három elemét különbözteti meg: (1) »tudáselemek« és »megszerzett ismeretek«, (2) »személyes adottságok« és »készségek«, valamint (3) »a szakképzettség konkrét környezetben, tevékenységrendszerben történő alkalmazása követelményeinek leírása«.” [Fischer - Halász, 2009 p. 12]

A Tempus Közalapítvány által kezdeményezett 2009-es kutatásban (LeO1) a tanulási eredmények alkalmazásáról egy kérdőíves felmérés keretében vizsgálták azt is, hogy milyen szakmai egyeztetések zajlottak a Képzési és Kimeneti Követelmények megfogalmazása során. Csupán a válaszadók egyharmada számolt be arról, hogy a munkáltatókkal, a diplomások várható foglalkoztatóival is folytatott megbeszéléseket, a hallgatók képviselőivel azonban senki nem egyeztetett. [Fischer - Halász, 2009]

2010-ben LeO2 néven egy újabb kutatást folytattak. Itt már nem csak kérdőíves felmérés volt, hanem dokumentumelemzés és interjúk is gazdagították az eredményeket.

A képzési és kimeneti követelmények kidolgozása során folytatott kommunikációt vizsgálva a 9. ábrán látható válaszokat kapták.

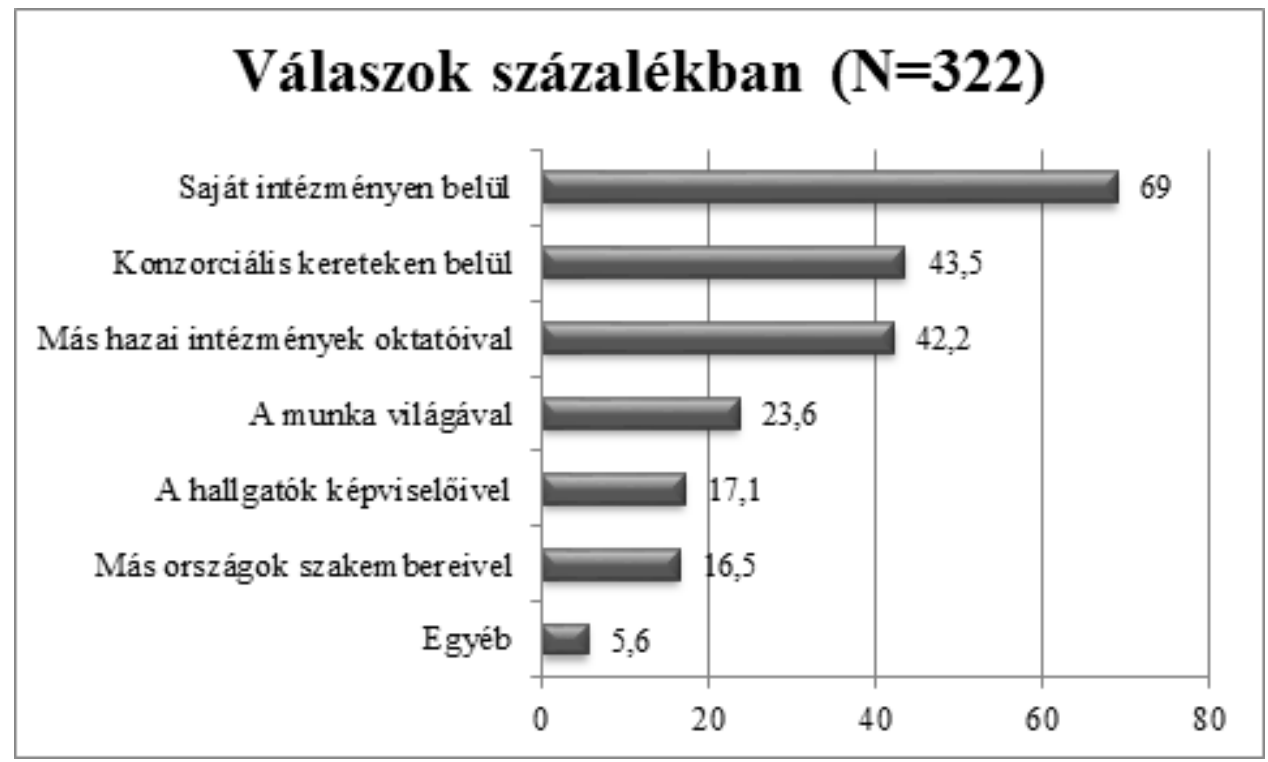

9. ábra A szakok képzési és kimeneti követelményeinek kidolgozásakor folytatott szakmai egyeztetések [Vámos, 2010 p. 33.] 
Akik több választ is bejelöltek, és azok között nem csak intézményen belüliek voltak, nagyon magas arányban alakították át a tantárgyi rendszert, újítottak a tanulásszervezésen és az értékelésen is.

„Mindent egybe vetve a ciklusos képzésre való áttérésben a kooperáció, s tudáskumulálás gyenge pont. A dokumentumelemzés és az interjúk is alátámasztották, hogy ebből a szempontból a magyar felsőoktatásra a tanszékek szigetszerü müködése jellemző, melyek között nincs, vagy gyenge a kapcsolat.” [Vámos, 2010 p. 11.]

„Az interjúk szerint a tervezéssel megbízott vezetők vagy oktatók tudományterületi forrásokat, friss tudományos cikkeket és saját kutatások eredményeit tekintik át, és nem használják, nem támaszkodnak sem a tanulási eredmények jogszabályban olvasható leírására, sem olyan pedagógiai munkákra, amely azoknak a tanításba-tanulásba való átfordítását segíthetnék. A kurzustervezés szintjén szerénymértékű a nemzetközi kapcsolat vagy a munka világával való egyeztetés, aminek forszírozása pedig éppen a kimeneti szabályozás fontosságát hangsúlyozná, s felhasználói szempontokkal gazdagíthatná képességek és attitüdök leírását." [Vámos, 2010 p. 11.]

Bíztató azonban, hogy az oktatók 80,3\%-a igényli és fontosnak tartja a változást a tanulásszervezésben, tehát úgy tünik, hogy a gyakorlatban, az oktatók szintjén hamarabb megjelennek a változások, mint a szakfejlesztések szintjén. Az oktatók fontosnak tartják a kulcskompetenciák fejlesztését is, amit leginkább azzal magyaráznak, hogy a tömegképzéssel egyre nagyobb a hallgatók szórása a felkészültségben.

Dokumentumelemzéssel 84 kiválasztott kurzusleírást vizsgáltak, amiből kiderült, hogy az értékelés átalakítása a leggyengébb pont a tanulási eredmények alkalmazásában. [ $V a ́$ mos, 2010]

A közoktatás területén is van még elmaradásunk a kompetencia alapú megközelítés terén. Vass Vilmos tanulmányában 3 kiemelt, úgynevezett generikus kompetenciával foglalkozott részletesebben, ezek a kommunikációs, az együttmüködési és a problémamegoldó kompetencia. Többek között azt is vizsgálta, hogy ezek milyen módon jelennek meg a magyar közoktatásban, konkrétan a Nemzeti Alaptanterv és a kétszintü érettségi követelményei hogy nevesítik ezeket. A 5. táblázat számai az említések számát mutatják. [Vass, 2006] 
DOI: $10.14267 /$ phd.2014081

5. táblázat A kommunikációs, az együttmüködési és a problémamegoldó kompetencia megjelenése a Nemzeti alaptantervben és a kétszintű érettségi követelményrendszerében [Vass, 2006]

\begin{tabular}{|l|c|c|}
\hline \multicolumn{1}{|c|}{ KOMPETENCIA } & NAT & KÉTSZINTÜ ÉRETTSÉGI \\
\hline Kommunikáció & 5 & 2 \\
\hline Szóbeliség & 3 & 1 \\
\hline Írásbeliség & 3 & 3 \\
\hline Képi információ feldolgozása & 2 & 0 \\
\hline Információkezelés & 1 & 2 \\
\hline IKT & 3 & 0 \\
\hline Forráskezelés & 1 & 3 \\
\hline A kommunikáció értékelése & 1 & 2 \\
\hline Együttmúködés & 3 & 0 \\
\hline Nyitottság & 0 & 0 \\
\hline Empátia & 3 & 0 \\
\hline Szociális interakció & 2 & 0 \\
\hline Társas érzékenység & 1 & 0 \\
\hline Felelösségérzet & 2 & 0 \\
\hline Szervezőképesség & 0 & 1 \\
\hline Döntéshozatal & 3 & 2 \\
\hline Érvelés & 3 & 2 \\
\hline Vita & 2 & 4 \\
\hline Problémamegoldás & 12 & 1 \\
\hline Hibakeresés & 0 & 2 \\
\hline Döntéshozatal & 2 & 1 \\
\hline Rendszerelemzés és -tervezés & 2 & \\
\hline
\end{tabular}

\section{III.3. A gazdaságtudományok képzési terület szakjainak tar- talma}

\section{III.3.1. Az üzleti és közgazdasági szakterületek áttekintése a Tuning prog- ramban}

A Tuning program keretében az első és második fázisban (2000 és 2004 között) 9 szakterület képzési szerkezetét vizsgálták, köztük az ületi szakterületet is (Business). [González - Wagenaar, 2008] Később, a Tuning projekt kibővítése során más szakterületek is sorra kerültek, így a közgazdasági is (Economics). Ebben már nem csak Európai szereplők vettek részt. [OECD, 2011] Ezek eredménye az alábbi összefoglaló.

„Az üzleti és menedzser képzések célja, hogy elméleti és gyakorlati tudást és képességeket nyújtsanak, melyek javítják az üzleti és közgazdasági tevékenységek tervezését, szervezését, végrehajtását és ellenőrzését nemcsak a privát szektorban, de a közösségi és a nonprofit szektorban is." [Tuning, 2009 p. 21.] 
Nem meglepő, hogy az utóbbi évtizedekben nagyon megnőtt a kereslet az ilyen irányú képzések iránt. Európában 750 felsőoktatási intézmény kínál üzleti képzéseket minimum bachelor szinten, az Amerikai Egyesült Államokban, Kínában, Indiában és Mexikóban egyenként legalább 1000 intézmény. Az USA-ban évente több mint fél millióan szereznek ilyen jellegü diplomát.

Az üzleti diplomát adó programok Európa szerte (és világszerte) nagyon különbözőek, nem csak országonként, de országokon belül, sőt akár egy intézményen belül is találunk teljesen eltérő szerkezetű képzéseket. [Tuning, 2009] Ugyanígy a közgazdászképzés tartalmáról sincsen egységes álláspont. [OECD, 2011]

A gazdasági képzések különlegességére hívja fel a figyelmet tanulmányában Lars Engwall is, aki hangsúlyozza, hogy a menedzserképzésben nincs meg az az egyértelmü kapcsolat a diploma és a betölthető munkakörök között, mint mondjuk a jogász, vagy orvosi szakmában. Így a tananyagok körülhatárolása is nehézségbe ütközik. Ezek a képzések nagyon széles skálán mozognak. A standardizálás irányába hat, hogy van néhány kiemelkedő intézmény, akiknek a példáját követik a kicsik. Ugyanakkor jellemző az is, hogy meg akarják különböztetni magukat az egyes intézmények azzal is, hogy más-más képzést kínálnak. [Engwall, 2007]

Európában a 3 ciklusú képzésben egyre nagyobbak a különbségek, az alapszakok még több mindenben hasonlítanak, a mesterszakok már jobban, a doktori képzések pedig már nagy mértékben különböznek egymástól. Alapszinten a képzések a teljesen általánostól a specifikus képzésekig szóródnak:

- környezetorientált: a szervezetek politikai, piaci, ipari környezetére koncentrál, célja ezeknek a struktúráknak a megismertetése, az elméleti mikro és makroökonómiai folyamatok megértése

- vállalatorientált: egy vállalat teljes körü menedzsmentjének áttekintése, stratégia, szervezeti tervezés, emberi erőforrás, pénzügy

- tevékenység specifikus: a képzés idejének felében egyetlen tevékenységre, funkcióra koncentrál, pl. a marketingen belül pszichológia, fogyasztói viselkedés, reklámozás, marketingkutatás, marketing menedzsment, értékesítés menedzsment.

Valójában minden képzés tartalmazza mind a 3-at, a különbségek abból származnak, hogy milyen arányban keverik az intézmények ezeket az összetevőket. 
A gazdálkodástudományok másik ága, a közgazdaságtan. A problémák, eredmények és események közgazdasági megközelítése és értelmezése tipikusan az elérendő célok és a korlátozó körülmények azonosításával kezdődik. Az elemzés magyarázhatja az elosztást, az erőforrások felhasználását és ezek gazdasági és szociális következményeit mikró és makró szinten. Az egyetemi oktatásnak mindenképpen a kutatók tudására kell alapulnia és megmutatnia a hallgatóknak a közgazdaságtan dinamikus, mindig megújuló voltát. Nem csak a régi, klasszikus elméleteket kell tartalmaznia. [Becker, 2003; OECD, 2011]

A közgazdasági alapképzések 3 csoportba sorolhatók: általános közgazdasági képzés, specializált közgazdasági képzés és kombinált közgazdasági képzés.

Az általános képzések 3 fő komponense az elméleti alapok, a módszerek és az alkalmazások. Az alkalmazások leggyakoribb területei: egészség-gazdaságtan, ipari szervezetek, és munkaerő-gazdaságtan.

A specializált képzések is tartalmazzák az első két elemet: elmélet és módszerek, de emellett egy speciális területre koncentrálnak, például ökonometria, pénzügy, államháztartás, nemzetközi gazdaságtan, fejlesztés-gazdaságtan.

A vegyes képzések integrálják a közgazdaságtant egy másik témával. Megjegyzendö, hogy az üzleti szakokban is van közgazdasági komponens, különbözö, egyes esetekben akár 30\%-os súllyal.

Közgazdász alapképzéssel a munkaerőpiacon nem valószínű, hogy közgazdászként tudnak a hallgatók elhelyezkedni, inkább valami adminisztratív területen, de a helyből munkába lépők aránya, országonként változóan ugyan, de csökkenő tendenciát mutat. Gyakoribb, hogy a tanulmányokat tovább folytatják mester, illetve doktorandusz képzéseken, vagy más keretek között, aminek elvégzése után már közgazdászként tudnak elhelyezkedni. [OECD, 2011]

Csak az utóbbi években kezdték összegyüjteni, hogy milyen kompetenciákra is van szüksége egy végzett közgazdásznak. A W. Lee Hansen [2001] által publikált 6 kompetencia a következö:

- hozzáférés a létező tudáshoz

- a meglévő tudás iránymutatásának bemutatása: a kulcs elméletek magyarázata és azok felhasználási lehetőségeinek leírása

- a meglévő tudás interpretálása, értelmezése 
- közgazdasági adatok értelmezése és kezelése

- meglévő tudás alkalmazása

- új tudás létrehozása

A Tuning program keretében 2009-ben az alábbi tanulási eredményeket azonosították a közgazdasági képzés számára:

- Tárgyi tudás és annak megértése

- Tárgyi tudás és annak alkalmazása

- Releváns adatok és számszaki módszerek hatékony alkalmazása

- Hatékony kommunikáció

- Önálló tanulási képességek megszerzése [OECD, 2011]

A beazonosított tanulási eredmények mellett kiemeltek 4 speciális készséget, amire egy közgazdásznak szüksége van:

- elvonatkoztatás (absztrakció),

- elemzés, dedukció és indukció

- számszerüsítés és tervezés

- keretbe foglalás

\section{III.3.2. Képzési és kimeneti követelmények a gazdaságtudományok kép- zési területen Magyarországon}

Magyarországon szakot alapítani csak a képzési és kimeneti követelmények (továbbiakban KKK) megfogalmazásával és elfogadtatásával, képzést indítani pedig az így akkreditált szakok KKK-ban megfogalmazott pontjainak megfelelően lehet. Ennek köszönhetően a hasonló tartalmú szakok megnevezése a különböző intézményekben megegyezik, bár a KKK elég sok mozgásteret ad az egyes intézményeknek a konkrét szakok felépítést illetően. A gazdaságtudományok képzési terület szakjai két képzési ágba vannak sorolva, ezek a Közgazdasági és az Üzleti képzési ágak. Az ezekhez tartozó szakok pedig:

- Közgazdasági ág:

○ alkalmazott közgazdaságtan

○ gazdaságelemzés (2014-től gazdaság- és pénzügy-matematikai elemzés)

○ közszolgálati

- Üzleti ág:

○ emberi erőforrások 
○ gazdálkodási és menedzsment

○ kereskedelem és marketing

○ nemzetközi gazdálkodás

○ pénzügy és számvitel

○ turizmus-vendéglátás

○ üzleti szakoktató

Az alábbiakban ezen szakok képzési és kimeneti követelményeit fogom áttekinteni az üzleti szakoktató kivételével. [Nemzeti Erőforrás Minisztériuma, nd]

A III.2.4 fejezetben már említettem, hogy ezekben a képzési és kimeneti követelményekben nincs egységes szerkezet a kompetenciák és a tanulási eredmények megfogalmazásánál. Az látható azonban, hogy a gazdaságtudományok terület szakjainak leírása ugyanazt a felépítést követi. E szerint a 7. pont, ,,az alapképzési szak képzési célja, az elsajátítandó szakmai kompetenciák” a következőket tartalmazza: egy általános leírás a képzés céljáról olyan formában, hogy milyen ismeretek birtokában mire lesznek képesek, akik ezt a szakot elvégzik. Aztán felsorolás következik előbb arról, hogy a végzettek mit „ismernek” majd arról, hogy mire lesznek ,alkalmasak”. Ezek után a 8. pontban szerepel a törzsanyag ismeretkörökre bontása a hozzájuk rendelendő kreditek meghatározásával.

A 3. mellékletben táblázatos formában a teljes képzési és kimeneti követelmények összehasonlíthatók mind a 9 szakon. Néhány fontosabb pontot azonban kiemelnék ezek közül. Mind a 9 szak BA, mindegyik szakképzettség megnevezése „közgazdász ... alapképzési szakon” (angolul „Economist in ...”). (A 2014-es tanévtől kezdődően a gazdaságelemzés szak helyett akkreditált gazdaság- és pénzügy-matematikai elemzés szak Bsc., a KKK tartalmi része nem változott.)

A képzési idő a közgazdasági szakokon 6 félév, az üzleti szakokon 1 szak kivételével 7 félév, amiből 1 félév gyakorlat. Az egy kivétel az emberi erőforrások szak, ahol nincs gyakorlat, így csak 6 félév a képzés, pontosabban ,a szakmai gyakorlat az egyes ismeretkörökhöz kapcsolódó gyakorlati foglalkozásokon szerezhető meg.” A kreditek is ennek megfelelően alakulnak. A 6 féléves szakok 180, a 7 félévesek $180+30$ kredit értéküek. A kreditek elosztásában is az tapasztalható, hogy az emberi erőforráson kívüli üzleti szakok egyformák, a közgazdasági szakok viszont egymástól is különböznek kisebb mértékben. 
A 7. pontban szereplő általános képességleírás általában jól körülírja, hogy miről is szól az adott szak többnyire olyan megfogalmazásban, hogy ilyen és ilyen ismeretek birtokában képesek erre és erre. Mindegyik tartalmazza azt is, hogy alkalmasak tanulmányaik mesterképzési szakon történő folytatására.

A konkrét ismeretek és képességek felsorolásában elég sok az eltérés, de néhány tendenciát szeretnék kiemelni.

$\mathrm{Az}$ ismeretek felsorolásában szerepelnek a szakhoz kapcsolódó speciális ismeretek. Mindössze 3 szak sorolja fel információs rendszerek ismeretét: gazdaságelemzés szak gazdasági információs rendszereket; emberi erőforrások - az emberierőforrás-gazdálkodás szervezeti és információs rendszerének müködését; pénzügy és számvitel - a számviteli információs rendszert.

A képességek felsorolásánál túlnyomó többségben generikus képességek szerepelnek a felsorolásban, szakspecifikus képességek leginkább csak a kereskedelem és marketing illetve a pénzügy és számvitel szakoknál szerepelnek. A „legnépszerübb” generikus képességek, melyek a legtöbb szak felsorolásában szerepelnek valamilyen módon: önállóság, kommunikációs készség, valamilyen elemzési képesség, csoportmunka. Ez utóbbi 3 szaknál nem szerepel, ezek a gazdálkodási és menedzsment, a pénzügy és számvitel illetve a turizmus-vendéglátás szak.

Informatika szempontból érdekes, hogy a közgazdasági szakok mindegyikénél, az üzleti szakok közül viszont csak az emberi erőforrásoknál és a kereskedelem és marketingnél szerepel a felmérések, jelentések készítésének képessége. A döntés-előkészítésben is nagy szerepe van az informatikának, ez szintén a közgazdasági szakoknál és azon kívül az emberi erőforrásoknál és a gazdálkodás és menedzsment szaknál szerepel.

A prezentációs készség, amihez hozzá tartozik a prezentációk számítógépen való elkészítése is, az üzleti szakoknál jelenik meg: emberi erőforrások, nemzetközi gazdálkodás, pénzügy és számvitel és turizmus-vendéglátás.

Konkrétan az informatika szó csak 4 szaknál szerepel, szintén mindegyik üzleti szak: emberi erőforrások - ,informatikailag támogatott korszerü elemzési módszerek, tárgyalási és prezentációs technikák alkalmazására”; gazdálkodási és menedzsment - ,idegen nyelven és az informatika segítségével is a hazai és a nemzetközi üzleti környezetben hatékonyan kommunikálni”; pénzügy és számvitel - „korszerű informatikai eszközök használatára”; turizmus-vendéglátás - „,informatikai ismeretek alkalmazására”. 
Érdemes még áttekinteni, hogy a módszertani tárgyakra és köztük az informatikára melyik szaknál hány kredit van előirányozva. Gazdaságtani és módszertani tárgyak csoportjában mind a 9 szaknál szerepelnek a következők: matematika, statisztika, informatika, mikroökonómia, makroökonómia, nemzetközi gazdaságtan, pénzügy, vállalat-gazdaságtan, számvitel.

A közgazdasági szakoknál más nem is szerepel itt és összesen 60-70, illetve a gazdaságelemző szakon 60-85 kredit van hozzájuk rendelve. Ha egyenrangúnak tekintjük a 9 felsorolt tárgyat, akkor darabonként körülbelül 7 kredit jut.

Az üzleti szakokon a csoportot közgazdaságtani módszertani és üzleti alapozó tárgyaknak hívják. A fent felsorolt 9 tárgyon kívül minden szaknál szerepelnek még a következők: gazdasági jog, marketing, menedzsment, üzleti kommunikáció, szaknyelv, környezetgazdaságtan, egyéb alapozó üzleti ismeretek. Minderre összesen 80-90 kredit jut. Itt is az emberi erőforrások lóg ki kicsit a sorból: menedzsment helyett emberierőforrás-menedzsment szerepel, hiányzik az üzleti kommunikáció, viszont van készségfejlesztő gyakorlatok, vállalati pénzügyek, vezetés és szervezés és munkagazdaságtan. A hozzárendelt kreditérték 80-100 kredit.

Ha az egységes 5 szakot nézem és megint feltételezem a tárgyak egyenlőségét, akkor a 16 tárgyra egyenként $5-5,5$ kredit jut.

A szakmai törzsanyag keretében csak 2 szakon szerepel informatika. Emberi erőforrás szakon személyügyi informatika, pénzügy és számvitel szakon pedig pénzügyi és számviteli informatika.

A tételes elemzésből kirajzolódik, hogy a gazdaságtani szakok felépítése egymáshoz nagyon hasonló. Ugyanerre az eredményre jutott egy átfogó, duo-mining módszertant (szövegbányászat és adatbányászat kombinált alkalmazása) alkalmazó kutatás is a 2013-as évben. A kutatás nem csak a gazdaságtani szakok, hanem az összes alapszak KKK dokumentumát elemezte. A tananyag alapján egymáshoz legközelebb eső szakpárok listájában az emberi erőforrások kivételével az összes gazdaságtudományi szakot megtaláljuk. A 3 közgazdasági szak minden lehetséges párosításban szerepel a listán. A 6 üzleti szak közül a szereplő 5 szak szintén minden párosításban szerepel, de a közgazdasági és az üzleti szakok viszont nem esnek ennyire közel egymáshoz. [Kruzslicz, 2014] 
A képzési és kimeneti követelmények elég tág keretet engednek a szakokat indító intézményeknek a konkrét tantárgystruktúra felépítésében. A V.1. fejezetben bemutatott kutatások során elemeztem, hogy a gyakorlatban hogyan jelenik meg az informatika az egyes intézmények képzéseiben.

\section{III.4. Ontológia elméletek}

Eddig a tananyagtervezés elméleti megfontolásaival, pedagógiai és törvényi megközelítésével foglalkoztam. Technikai oldalról a tervezés egyik eszköze lehet az ontológiaépítés is.

Több ontológiaépítési módszertant is kidolgoztak, de ezek a legjobb esetben is csak felsorolás szerüen tartalmazzák a teljes folyamatot. Részletesen csak az ontológia valódi felépítését tartalmazzák. Hiányzik azonban az első lépés pontosítása, az ontológia tartalmának meghatározása, és kidolgozatlan az ontológia karbantartásának folyamata is. [Fernández-López,2002; Vas,2007] Ezekhez a hiányzó részekhez adnak támpontot a III.1. fejezetben részletezett pedagógiai elméletek.

A Sure-Studer féle On-To-Knowledge módszertan a CommonKADS fejlesztési szabvány egy módosított változatát veszi alapul. Az egyes fázisok:

- megvalósíthatósági tanulmány: problémák és lehetőségek azonosítása, ígéretes fókusz terület és célmegoldás kiválasztása

- kiindulási fázis: követelményspecifikáció, input források elemzése, alap taxonómia kialakítása

- finomítás: fogalmak összegyüjtése szakértők bevonásával, alap taxonómia kialakítása, fogalmi modellezés, formalizálás, relációk, axiómák megadása

- értékelés: átvizsgálás és bővítés a visszajelzések alapján, alkalmazási minták elemzése, kompetenciakérdések elemzése

- karbantartás és fejlesztés: szervezeti fenntartás folyamatainak irányítása.

Utóbbi 3 ciklikus folyamatban. [Fernández-López, 2002; Staab et al., 2001; Vas, 2007]

\section{III.4.1. Informatikai tudástárak, ontológiák}

A nemzetközi szakirodalomban az informatikaoktatás tartalmát is próbálják ontológia alapon összegyüjteni [Chin at. al, 2007]. 
Számos nemzetközi kezdeményezés létezik az informatika területének teljes feltérképezésére. Csak néhány példát említve:

- European e-Competenece Framework [http://www.ecompetences.eu/],

- EUCIP (korábban EPIC): European Certification of Informatics Professionals [http://www.ecdl.org/eucip/index.jspwww.cepis.org/media/EUCIP_Version_31.pdfhttp://www.cepis.org/index.jsp?p=1120\&n=1121http://www.cepis.org/index.jsp?p=1120\&n=1122],

- SWEBOK: Software Engineering Body of Knowledge [http://www.computer.org/portal/web/swebok/home].

Ezek általában szoftverfejlesztéssel, informatikai rendszerek tervezésével, bevezetésével, karbantartásával, IT biztonsággal foglalkoznak és jóval szélesebb körüek, mint amire egy általános közgazdász képzésben szükség van.

\section{III.5. Képzések határterületei}

Az eddigi fejezetekben a tananyag tervezéséről általánosságban volt szó, illetve a képzési területek teljes oktatási tartalmának megtervezéséről. Számos területen azonban ezek a szakterületek összeérnek. A találkozási pontoknál pedig a szűkítés eszközét kell alkalmaznunk, hogy a fő szakterülethez kapcsolódó releváns tartalmak kerüljenek be a felsőoktatásba.

Megemlítem, hogy a III.2.3. fejezetben ismertetett Tuning projektben az üzleti szakterületen megfogalmazták, hogy a kifejezetten üzleti képzéseken kívül hol és milyen mélységben fordulnak még elö üzleti tartalmak. [González - Wagenaar, 2008; OECD, 2011] Az üzleti tanulmányok megjelennek számos más szakterület képzésében. Ezek alapján az üzleti képzést is nyújtó szakoknak 5 szintjét különböztethetjük meg:

1. Szimpla üzleti képzés: a program döntő többsége üzleti modulokból áll

2. föként üzleti képzés: az üzleti modulok a program nagyobb részét, körülbelül 75\%-át teszik ki. A legtöbb üzleti alapképzés ide tartozik.

3. kapcsolódó üzleti képzés: az üzleti tartalmak egy másik diszciplínával párhuzamosan szerepelnek, fele-fele arányban. A társult tudományterület lehet pl. közgazdaságtan, szociológia, pszichológia, jog, politikatudomány, információrendszerek, számítástechnika vagy mérnöki tudományok. 
4. alárendelt üzleti képzés: az üzleti modulok kisebb arányt, kb. 25\%-ot képviselnek a teljes programon belül. Nagyon gyakori Európában a mérnöki alapszakok kapcsolása alárendelt üzleti képzéssel.

5. csak üzleti modulok: a teljes program maximum 10\%-át teszik ki az üzleti modulok, esetleg csak választható formában. Például gyógyszerész szakon aki patikát szeretne a későbbiekben üzemeltetni, annak szüksége lehet némi gazdasági ismeretre, de aki laboratóriumban kíván csak dolgozni, az nem fogja ennek a modulnak a tárgyait választani. [González - Wagenaar, 2008]

Figyelmet fordítottak a másik oldalra is, megállapították, hogy az üzleti képzésben jelen van sok más tudományterület, így a filozófia, pszichológia, matematika, statisztika, informatika, mérnöktudományok. [González - Wagenaar, 2008]

A 2008-ban folytatott felmérésben szakmaspecifikus kompetenciák fontossági sorrendjét is vizsgálták 4 érdekelt csoport körében: munkáltatók, végzettek, hallgatók és oktatók. Itt nagyobb eltérések kerültek felszínre, mint az általános kompetenciáknál. Az informatika szerepének szempontjából két kompetencia helyzete az érdekes:

Információs rendszerek tervezése és kivitelezése: a munkáltatók a 7. helyre sorolták a 25ből, a másik 3 csoport az utolsó 4 hely valamelyikére: végzettek 22., hallgatók 25., oktatók 24 .

A megfelelő szoftver azonosítása és használata. Itt valamivel kisebb a különbség, érdekes módon az oktatók ezt jóval előbbre sorolják, de a végzetteknél és a hallgatóknál elég hátul kullog: a munkáltatók 8., a végzettek 16., a hallgatók 22. és az oktatók 7. helyre tették. [Tuning, 2009]

Közgazdasági területen a Lee Hansen által megfogalmazott 6 kompetencia közül a 4.-et szükséges kiemelnünk: a közgazdasági adatok értelmezése és kezelése. Itt a szerző kifejti, hogy értelmezni és használni kell tudni azokat a számszerü adatokat, amelyeket nyilvánosan publikált táblázatokban találnak. Fel kell tudni ismerni a mintázatokat és a trendeket az adatokban. Táblázatokat kell tudni létrehozni a fellelhető adatokból. [Hansen, 2001] Ezek mind módszertani feladatok, statisztikai, matematikai tudást igényelnek, de végrehajtásukhoz elengedhetetlen az informatika, mint eszköz használata.

A technológiai fejlődés hatással kell legyen a közgazdasági képzés tartalmára is. A számológép megjelenésével érdektelenné vált a logarléc használata, a számítógépes táblá- 
zatkezelő és statisztikai programcsomagok megjelenésével a számológép is veszített jelentőségéből. A modern számítástechnika segítségével a közgazdaságtan sokkal inkább empirikus tudománnyá tud válni, bár az alapképzésben ez kevéssé jelenik meg. [Becker, 2003]

A 2009-ben azonosított tanulási eredmények közül a releváns adatok és számszaki módszerek hatékony alkalmazása és ehhez kapcsolódóan a közgazdászok számára kiemelten szükséges speciális készségek közül a számszerüsítés és tervezés kifejtése az iránymutató. „Az adatok hatékony elrendezése, prezentálása és elemzése fontos a közgazdaságtanban. Az átlagos hallgató megismeri a közgazdasági információk és az ipari, kereskedelmi, társadalmi és kormányzati adatok elsődleges forrásait. Tapasztalatot kell szerezniük ezen adatok informatív elrendezésében és bemutatásában. Ezek a készségek a döntéshozatal minden állomásánál fontosak. A munkáltatónak olyan közgazdászokra van szüksége, akik a számszerü adatokat tudják strukturálni, elemezni és megmagyarázni. A nyers adatok általában táblázatokban (vagy adatbázisokban) vannak, a feldolgozott adatok viszont grafikonok, átlagok, korrelációk és így tovább. Az ilyen típusú információk kezelése számtani, statisztikai és számítástechnikai készségeket igényel. Az ilyen számszerü információk használható formában történő kommunikálásához és különösen a nyersen nem értelmezhető adatok kritikus és egységes összefoglalójához szükségesek a prezentációs készségek." [OECD, 2011 p. 29]

Az informatikusok oldaláról kevesebb elemzést találunk arról, hogy mit is tudnak nyújtani más szakterületek képviselőinek. Mélyreható kutatások, feltárások az informatika egyes szakterületeiről találhatók, például az orvosi informatikáról [Mantas at. al., 2011], vagy a gazdaságinformatikáról, melynek külön évente megrendezett konferenciája van Magyarországon.

A gazdaságinformatikusok olyan szakemberek, akik képesek ,az üzleti problémák infokommunikációs technikákkal támogatott megoldására, gazdasági, közgazdasági szakemberekkel, partnerekkel, informatikai fejlesztéseket végző munkatársakkal való együttmüködésre, akár idegen nyelven is. Az üzleti folyamatok végrehajtását segítő szoftveralkalmazásokat terveznek. Ellátják az adatbázisok tervezésével, létrehozásával és menedzselésével kapcsolatos feladatokat. Feladatuk a szervezeten belüli informatikai egységek menedzselése, müködtetési kockázatok kezelése, kisebb fejlesztési és üzemeltetési projektek tervezése, irányítása." 
[http://www.felvi.hu/felveteli/szakok_kepzesek/szakleirasok/!Szakleirasok/index.php/szakleirasok/szakleiras_konkret?szak_id=31\&kepzes $=A]$

A gazdaságinformatika tudományának ontológia megközelítésű felépítése látható a 4 . mellékletben. [Gábor András közlése alapján, Corvinno Technológia Transzfer Központ] Kevesebb szó esik azonban a nem informatikus szakok informatikaoktatásáról. Itt elsősorban szintén az orvosképzésben találunk példákat [Almási at. al., 2011., Bari at. al., 2011.], illetve a pedagógusképzésről születnek még nagyobb számban tanulmányok [Bakó, 2008].

Arról azonban, hogy a gyakorlati közgazdásznak milyen felhasználói ismeretekre van szüksége és azt hol és hogyan tudja megszerezni, csak egy-egy speciális területen (pénzügy, számvitel) találtam beszámolót [Honfi at. al., 2008; Barna - Honfi, 2008]. Az általános közgazdászok informatika képzésének tartalmáról egyelőre kisebb szakmai összejöveteleken esik csak szó, mint a Budapesti Kommunikációs Főiskola Módszertani Intézete által szervezett Módszertani Szakmai Napok (2012. Mártély ${ }^{6}$, 2013. Kismagos ${ }^{7}$ ).

Érdekes még párhuzamot vonni a matematika oktatásával. A Budapesti Corvinus Egyetem Matematika tanszékének oktatói 2010-ben tekintették át a matematikaoktatás gyakorlatát a Bologna típusú gazdasági képzésekben. Arra a szomorú következtetésre jutottak, hogy a gazdálkodástani képzésben résztvevő nagy magyar egyetemek (a cikkben M4nek emlegetett Budapesti Corvinus Egyetem (BCE), Debreceni Egyetem (DE), Pécsi Tudományegyetem (PTE) és Szegedi Tudományegyetem (SZTE)) matematika képzése öszszehasonlításban a nagy európai egyetemekkel nagyon alacsony szinten van. Kutatásukban nem az egyes szakok képzési és kimeneti követelményeit, vagy a munkaerőpiacot vizsgálták, inkább a tudomány szempontjából, a potenciális $\mathrm{PhD}$ hallgatók kinevelésének lehetősége felől közelítették a kérdést és összehasonlító elemzést végeztek az európai egyetemek hasonló szakjaival. [Kánnai at. al., 2010]

Külön vizsgálandó az is, hogy a gazdaságtudományok képzési területen belül azonosítható-e a különbség az egyes szakok informatikai igénye között. Előfordulhat, hogy a kimeneti követelmény azonos lehet a különböző szakokon, de a megtanítás módjában lehet

${ }^{6}$ http://www.bkf.hu/hirek/7830/modszertani-napok-martelyon.html, utolsó megtekintés 2013. október 28. 7http://www.bkf.hu/hirek/7973/modszertani-napok-kismagoson.html utolsó megtekintés 2013. október 28. 
eltérés, mondjuk az adott szakhoz kapcsolódó gyakorlati példák felhasználásával. Párhuzamként említeném Sós Katalin előadását a MAFIOK XXXIV. konferencián a fizikatanításról a különböző nem fizikus szakok számára. [Sós - Nánai, 2011]

\section{III.6. Áttekintés a középiskolai informatika tananyagról}

Ha meg akarjuk határozni, hogy mi az informatikaoktatás feladata a felsőoktatásban, akkor elkerülhetetlen annak a felmérése, hogy milyen bejövő ismereteket feltételezhetünk. Két út kínálkozik a válasz megtalálására.

Az egyik a jogszabályok áttekintése, hogy lássuk elvileg mit kötelező a hallgatóknak megtanulni a középiskolában. A másik az empirikus kutatás, amely során egy kérdőív segítségével a valóban meglévő ismeretekre kérdezhetünk rá. Az utóbbira tettünk kísérletet a V.1 fejezetben bemutatott kutatással. Ebben a fejezetben a jogszabályi hátteret tekintem át.

A Nemzeti Alaptantervet különböző kormányrendeletek szabályozzák. Ezek közül az első az 1998 szeptember óta hatályos Nat-1995, melyet az 1. és a 7. évfolyamon kezdtek el bevezetni. Ebben a tanévben még ennek a szabályozása a mérvadó a nappali tagozatot kezdő hallgatók tekintetében. Az alábbi felsorolás egy rövid áttekintést ad a Nat-ról szóló kormányrendeletekről, melyből kiszámolható, hogy melyik tanévben melyik tanterv szerint tanult hallgatók kerülnek a legnagyobb arányban a felsőoktatásba [Nemzeti alaptanterv, 1995; 2003; 2007; 2012]:

- Nat-1995, hatályos 1998 szeptembertől 1. és 7. évfolyamon (az utolsó évfolyam 2014-ben érettségizik)

- Nat-2003, hatályos 2004 szeptembertől 1. évfolyamon

- Nat-2007, a 2003-as NAT módosítása, jelenleg ez a hatályos, felmenő rendszerben a 11. évfolyamnál tart (az egyetlen évfolyam 2015-ben érettségizik)

- Nat-2012, hatályos 2013 szeptembertől, 1., 5. és 9. évfolyamon (az első évfolyam 2016-ban érettségizik).

A 95-ös tantervben a 8. müveltségi terület az informatika. Ennek fejezetei:

- Számítástechnika

○ A számítástechnika alapjai

- Az operációs rendszer használata

○ Algoritmizálás 
○ Számítógéppel segített problémamegoldás

○ Szöveg- és ábraszerkesztés

○ Táblázatkezelés

○ Adatbázis-kezelés

- Könyvtárinformatika

Ennek megfelelően az informatika érettségin a tartalomorientált kompetenciák a következők [Érettségi követelmények, 2002]:

(1) Információs társadalom
a. kommunikáció (középszint)
b. információ és társadalom (középszint)

(2) Informatikai alapismeretek - hardver
a. jelátalakítás és kódolás (középszint)
b. a számítógép felépítése (közép- és emelt szint)

(3) Informatikai alapismeretek - szoftver
a. az operációs rendszer (középszint)

(4) Szövegszerkesztés
a. szövegszerkesztő használata (középszint)
b. szövegszerkesztési alapok (középszint)
c. szövegjavítási funkciók (középszint)
d. táblázatok, grafikák a szövegben (középszint)

(5) Táblázatkezelés
a. táblázatkezelö használata (középszint)
b. táblázatok felépítése (középszint)
c. adatok a táblázatokban (középszint)
d. táblázatformázás (középszint)
e. táblázatok, szövegek, diagramok (középszint)
f. problémamegoldás táblázatkezelővel (középszint)

(6) Adatbázis-kezelés
a. adatbázis-kezelés alapfogalmai (közép- és emelt szint)
b. adatbázis-kezelő program interaktív használata (közép- és emelt szint)
c. alapvető adatbázis-kezelési müveletek (közép- és emelt szint)
d. képernyő és nyomtatási formátumok (közép- és emelt szint)

(7) Információs hálózati szolgáltatások 
a. kommunikáció az Interneten (középszint)

b. web-lap készítés (közép- és emelt szint)

(8) Prezentáció és grafika

a. prezentáció (középszint)

b. grafika (középszint)

(9) Könyvtárhasználat

a. könyvtárak (középszint)

b. dokumentumok (középszint)

c. tájékoztató eszközök (középszint)

(10) Algoritmizálás; adatmodellezés, programozási ismeretek (csak emelt szinten)

(11) A programozás eszközei (csak emelt szinten)

Jelen értekezés szempontjából a középszinten megfogalmazott követelmények a relevánsak, hiszen informatikából emelt szintü érettségit általában azok tesznek, akik ilyen irányban akarnak tovább tanulni.

\section{III.7. ECDL}

A felhasználói ismeretek feltérképezésére a szintén a CEPIS által létrehozott ECDL követelményrendszere egy jó kiindulási alap, ami elég részletesen megtalálható a szervezet honlapján (http://ecdl.hu). Az ECDL úgy definiálja magát, mint az „informatikai írástudást igazoló bizonyítvány”. Vitathatatlan előnye, hogy gyártófüggetlen, minőségbiztosított, decentralizált módon megszerezhető és világszerte kellőképpen elterjedt. A követelményrendszer harmonizál a magyarországi középiskolai informatika anyaggal, megfelelő szinten teljesített informatika érettségivel (közép- és emelt szinten jeles osztályzattal)ECDL bizonyítványt lehet szerezni. [ECDL, $\left.n d_{a}\right]$

Az ECDL alapmoduljainak tartalma ennek megfelelően azt mutatja meg, hogy mi az az alapvető tudás, amit már a hallgatók az egyetemi képzés előtt megszerezhetnek. Természetesen nem egyértelmü, hogy a hallgatók ezzel a tudással valóban rendelkeznek, amikor az egyetemre kerülnek, mégis úgy gondolom, hogy a felsőoktatás feladata ott kezdődik, ahol az ECDL alapmoduljainak követelménye véget ér.

Az ECDL alap moduljai 2013 október 15-ig:

- IKT alapismeretek 
- Operációs rendszerek

- Szövegszerkesztés

- Táblázatkezelés

- Adatbázis-kezelés

- Prezentáció

- Internet és kommunikáció

Létezik az úgynevezett ECDL Advanced bizonyítvány is, amely 4 területen (szövegszerkesztés, táblázatkezelés, adatbázis-kezelés és prezentációkészítés)sokkal átfogóbb. Ennek megszerzése sokkal kevésbé gyakori. A 2012-13-as tanév elején lefolytatott kutatásban az 1441 megkérdezett hallgatóból mindössze 15 jelölte meg, hogy van legalább egy advanced vizsgája, míg valamilyen ECDL vizsgával 270-en rendelkeznek, az egy évvel későbbi kutatásban ez a szám mindössze 3 fő az 569-ből (V.1. fejezet).

1996 és 2013 között több mint 100 ország több mint 13 millió embere szerzett ECDL bizonyítványt, Magyarországon több mint 430 ezren tettek ECDL vizsgát.

Az informatika felhasználói szintủ megközelítésének változását mutatja, hogy 2013. október 15-től átalakulnak az ECDL moduljai. A most megújuló ECDL célja, hogy lépést tartson a technológiai és munkaerő-piaci változásokkal.

A legtöbb modul tekintetében ez csak a névben, illetve új vizsgafeladatokban nyilvánul meg. A leglényegesebb változás viszont, hogy az IKT alapismeretek és az Operációs rendszerek modulok egyesítéséből új modul lesz, a neve: Számítógépes alapismeretek (Computer Essentials). A korábbi IKT alapismeretek és Operációs rendszerek modul megszünik. Az új modul inkább gyakorlati jellegü lesz és az operációs rendszerek használatára épül, elméletből a legfontosabb tudnivalókat tartalmazza. [ECDL, 2013]

Ennek megfelelően a modul tanulási eredményeit az alábbiak szerint fogalmazták meg: „A vizsga sikeres teljesítéséhez a vizsgázó:

- értse az IKT, a számítógép és az egyéb eszközök és szoftverek témájával kapcsolatos alapvető fogalmakat,

- indítsa el és megfelelően kapcsolja is le a számítógépet,

- hatékonyan tudjon dolgozni az asztalon található ikonokkal és az ablakokkal,

- képes legyen módosítani az operációs rendszer főbb tulajdonságait, és használja a beépített súgó funkciókat,

- képes legyen létrehozni és kinyomtatni egy egyszerű dokumentumot, 
- ismerje a fájlkezelés főbb fogalmait és hatékonyan tudjon fájlokat és mappákat rendszerezni,

- értse az alapvető adattárolási fogalmakat és tudjon fájlokat tömöríteni,

- értse a hálózati fogalmakat, a csatlakozások típusait és képes legyen az internethez csatlakozni,

- tisztában legyen az adatvédelem fontosságával, a malware és a biztonsági mentés fogalmával,

- ismerje a környezetvédelmi, hozzáférhetőséggel és a felhasználói egészséggel kapcsolatos megfontolásokat" $\left[E C D L, n d_{b}\right]$

Kisebb hangsúlyt kaptak a követelmények között az alábbi pontok:

- tudnia kell, mi a hardver, milyen tényezők befolyásolják a számítógép teljesítményét, valamint ismernie kell a perifériákat is;

- tudnia kell, mi a szoftver, és példákkal kell tudni illusztrálni néhány általánosan használt alkalmazást és operációs rendszert;

- tudnia kell, mit értünk információs és kommunikációs technológiák alatt, és példákat kell tudni említeni azok mindennapi életben történő gyakorlati alkalmazására; $\left[E C D L, 2009_{a}\right]$

Ezen kívül két új modul is létrejön, követve a technológiai fejlődést: IT Biztonság, Elektronikus hitelesség, elektronikus aláírás [ECDL, 2013]

Az új és megújuló modulok bevezetésével alkalmazott ECDL Select és Select Start modulrendszer felépítése az alábbiak szerint alakul:

ECDL Select 4 kötelező modulja: számítógépes alapismeretek, szövegszerkesztés, táblázatkezelés, online alapismeretek. E mellé kell választani 3-at a további modulok közül: adatbázis-kezelés, prezentáció, képszerkesztés, webszerkesztés, IT biztonság, E-hitelesség/e-aláírás.

Az ECDL Select start 3 kötelező modulja: számítógépes alapismeretek, szövegszerkesztés, online alapismeretek. E mellé kell választani 1-et a további modulok közül. 


\section{VIZSGÁLAT CÉLJA, KUTATÁSI TERV}

\section{IV.1. A vizsgálat célja}

Az előző fejezetben kifejtett elméletek és történeti áttekintés alapján világos, hogy a gazdaságtudományok tudományterületen az informatika oktatásának fontos szerepe van, annak tartalmának kialakításához, céljának meghatározásához azonban elég kevés a kézzelfogható iránymutatás. Kutatásom azt a célt szolgálja, hogy a bolognai folyamat alapelveinek és a kompetencia megközelítéseknek megfelelően, számos érintett nézőpontját figyelembe véve egy ajánlást tudjak megfogalmazni arról, hogy hogyan kellene felépülni az alapozó informatikaoktatásnak a gazdaságtudományok képzési területen. Ennek megfelelően több empirikus kutatás lefolytatásával keresem a választ az I. fejezetben megfogalmazott kutatási kérdésekre.

\section{IV.2. Kutatási terv}

A III.1.1. fejezetben bemutattam, hogy a tantervfejlesztés során milyen érintettekkel kell számolni, kiknek a véleménye a mérvadó. Ennek megfelelően a kutatás is több forrásra támaszkodik. A jelenlegi és a végzett hallgatókat kérdőívvel kerestem meg. A munkaerőpiac igényeit is a végzett hallgatók segítségével próbáltam felmérni. A tudomány és az oktatók szempontját az oktatókkal folytatott interjúkkal és szakirodalmi kutatással térképeztem fel. A jelenlegi gyakorlat vizsgálatához dokumentumelemzést alkalmaztam. A következő fejezetekben az egyes kutatások eredményei kerülnek kifejtésre.

A Budapesti Corvinus Egyetem (továbbiakban BCE, korábban Budapesti Közgazdaságtudományi és Államigazgatási egyetem, BKÁE) az egyetlen magyar intézmény, amely mind a 9 alapszakot indítja, a közgazdasági szakoknak önállóan szaklétesítője (a gazdaságelemzés, 2014-től gazdaság- és pénzügy-matematikai elemzés szak egyetlen szakindítója) és az üzleti szakokat létesítő konzorciumok egy részének is tagja (gazdálkodási és menedzsment, nemzetközi gazdálkodás és pénzügy és számvitel szak). A konzorciumok teljes összetétele a Kutatásaimban elsősorban a BCE hallgatóit, végzettjeit és oktatóit kérdeztem. Ezen kívül két olyan föiskolán folytattam még kutatásokat, melyeknek egyik képzési területe a gazdaságtudományok. Ezek az Általános Vállalkozási Főiskola (továbbiakban ÁVF) és a Budapesti Kommunikációs Főiskola (továbbiakban BKF). A kérdő- 
ívek és interjúk a teljes magyar gazdálkodástani felsőoktatás tekintetében nem reprezentatívak, de mivel a BCE minden szakon indít képzéseket, és a képzések létszámában is az élen van, az egyetemre vonatkozó következtetések kiterjeszthetők a többi intézményre is. 6. táblázatban látható.

Kutatásaimban elsősorban a BCE hallgatóit, végzettjeit és oktatóit kérdeztem. Ezen kívül két olyan föiskolán folytattam még kutatásokat, melyeknek egyik képzési területe a gazdaságtudományok. Ezek az Általános Vállalkozási Főiskola (továbbiakban ÁVF) és a Budapesti Kommunikációs Főiskola (továbbiakban BKF). A kérdőívek és interjúk a teljes magyar gazdálkodástani felsőoktatás tekintetében nem reprezentatívak, de mivel a $\mathrm{BCE}$ minden szakon indít képzéseket, és a képzések létszámában is az élen van, az egyetemre vonatkozó következtetések kiterjeszthetök a többi intézményre is.

6. táblázat Az üzleti szakokat létesítő konzorciumok [közli Négyesi Judit szakreferens, Magyar Felsőoktatási Akkreditációs Bizottság]

\begin{tabular}{|c|c|}
\hline $\begin{array}{c}\text { ALAPSZAK } \\
\text { MEGNEVEZÉSE }\end{array}$ & KONZORCIUM TAGJAI \\
\hline $\begin{array}{l}\text { kereskedelem és } \\
\text { marketing }\end{array}$ & [KVK]: BGF/MÜTF/SZF \\
\hline $\begin{array}{c}\text { gazdálkodási és } \\
\text { menedzsment }\end{array}$ & $\begin{array}{c}{[\mathrm{KVK}]:} \\
\mathrm{BGF} / \mathrm{AVF} / \mathrm{BDF} / \mathrm{BKF} / \boldsymbol{B} \boldsymbol{K} \boldsymbol{A} \boldsymbol{E} / \mathrm{BME} / \mathrm{BMF} / \mathrm{DE} / \mathrm{DF} / \mathrm{EJF} / \mathrm{EKF} / \mathrm{GDF} / \\
\mathrm{HJ} / \mathrm{HFGTSZF} / \mathrm{KE} / \mathrm{KRFKJF} / \mathrm{ME} / \mathrm{MÜTF} / \mathrm{NÜF} / \mathrm{NYF} / \mathrm{NYME} / \mathrm{PTE} / \\
\mathrm{SZE} / \mathrm{SZTE} / \mathrm{SZIE} / \mathrm{TSF} / \mathrm{PE} / \mathrm{ZMNE}\end{array}$ \\
\hline $\begin{array}{l}\text { nemzetközi } \\
\text { gazdálkodás }\end{array}$ & {$[\mathrm{KVK}]: \mathrm{BGF} / \mathrm{BDF} / \mathrm{BKF} / \underline{\boldsymbol{B} \boldsymbol{A} \boldsymbol{A} \boldsymbol{E} / \mathrm{SZE} / \mathrm{SZF}}$} \\
\hline $\begin{array}{l}\text { pénzügy és } \\
\text { számvitel }\end{array}$ & {$[\mathrm{KVK}]: \mathrm{BGF} / \underline{\boldsymbol{B} \boldsymbol{K} \boldsymbol{A} \boldsymbol{E}} / \mathrm{KRF} / \mathrm{NÜF} / \mathrm{TSF} / \mathrm{ZMNE}$} \\
\hline $\begin{array}{c}\text { emberi } \\
\text { erőforrások }\end{array}$ & [KVK]: BGF/KRF/SZIE/PE/ZSKF \\
\hline $\begin{array}{l}\text { turizmus- } \\
\text { vendéglátás }\end{array}$ & [KVK]: BGF/HJF/HFGTSZF/KRF/KJF/NYME/ SZF/PE \\
\hline
\end{tabular}

\section{IV.2.1. A jelenlegi gyakorlat - dokumentumelemzéssel}

Elözetes kutatásként 2010 nyarán a gazdálkodástudományok képzési területen szakot indító hazai felsőoktatási intézmények közel kétharmadának informatikai tárgyait elemeztem szövegbányászati és statisztikai eszközökkel. 34 intézményben, 188 szakon folyt a 
gazdálkodástudományok körébe tartozó képzés, ebből 109 alap és 79 mesterszak. A kutatásban csak az alapszakok tárgyait vizsgáltam, mert erre vonatkozóan találtam pontosabb adatokat.

A 2013-as év őszi félévében részletesen összehasonlítottam a Budapesti Corvinus Egyetem és az Általános Vállalkozási Főiskola gazdasági szakjainak mintatantervét informatikaoktatás szempontjából.

2014-ben áttekintettem néhány Európai egyetem gyakorlatát is.

A három kutatás menetét és eredményeit a V.1. alfejezetben ismertetem.

\section{IV.2.2. A bejövő hallgatók informatikai előismeretei - kérdőíves felmérés}

A felsőfokú tanulmányaikat kezdő hallgatók informatikai előismereteit több időpontban is vizsgáltam. A bejövő ismeretek empirikus vizsgálata két okból is szükségesnek tünik. Egyrészt eddigi tapasztalataink azt mutatják, hogy hiába a törvényi előírás (amit a III.6. fejezetben tekintettem át), a középiskolai informatikaoktatás sok helyen elmarad ettől. Másrészt a hallgatók más, nem iskolai forrásokból is gyüjtenek informatikai ismereteket. Az első vizsgálat a 2005-2006-os tanévben történt a BCE hallgatóinak körében, még a bolognai folyamat indulása előtt. A kutatásban Németh Zoltán tanszéki munkatárssal közösen dolgoztunk. A kutatás két félévben zajlott, nem teljesen egyforma kérdőívvel, így bizonyos információk a teljes megkérdezett sokaságra rendelkezésre állnak (n=930, az akkori elsős hallgatók közel 100\%-a), mások csak a második félévben megkérdezett hallgatókra (n=406, az akkori elsős hallgatók 40\%-a).[Baksa-Haskó, 2007]

A második kutatás a 2012-13-as tanévben beiratkozott hallgatók bejövő ismereteire koncentrált 3 intézményben. A BCE-n és a BKF-en elektronikusan töltötték ki a kérdőívet az elsős hallgatók informatika órán, az ÁVF-en papíron történt a kitöltés beiratkozáskor. Az ÁVF-en nappali és levelező tagozaton közel teljes körü (94\%-os válaszadás), a BKF-en a nappali tagozaton 95, a levelező tagozaton 37\%-os, a BCE Gazdálkodástani és Közgazdasági karán nappali tagozaton pedig 46\%-os válaszadás alapján a magas kiválasztási arány miatt az eredmények az egyes intézmények hallgatóira vonatkozóan reprezentatívnak tekinthetőek. A teljes gazdaságtudományok területen felsőoktatásba lépő hallgatók sokaságát tekintve a minta nem reprezentatív, így a következtetéseket csak a 3 megnevezett intézményre fogalmazom meg. 
A kérdőíves kutatás sem nyújt teljes egészében megnyugtató válaszokat, mert önbevalláson alapul, és az eredmények nem mindig fedik a valóságot a valódi tudás tekintetében. Ez nem elsősorban a kitöltők őszinteségén, hanem inkább a kitöltők hibás önértékelésén múlik. Ezt a szempontot is igyekeztem figyelembe venni a 3. kutatás előkészítésekor, így a 2013-14-es tanév elején kitöltetett kérdőív az előző éves kérdőív egy kibővített változata volt, a második blokkban teszt kérdésekkel, melyek az egyes területeken meglévő valódi ismeretekre vonatkoztak. A 3 kutatás eredményét és összehasonlítását a V.1. fejezetben ismertetem.

\section{IV.2.3. A szaktárgyak és a módszertani tárgyak oktatóinak tapasztalatai és gyakorlata - interjúk}

Az ÁVF-en a kollégákat egy csoportos interjúsorozat keretében kérdeztem 2011. december és 2012. február között. A BCE-n a szakfelelős tanszékeket fogom felkeresni 2013. november folyamán. A beszélgetéseket a V.3. fejezetben ismertetem.

\section{IV.2.4. A végzett hallgatók munkahelyi tapasztalatai - kérdőíves felmérés}

A felsőoktatás tananyagának összeállításánál nem lehet figyelmen kívül hagyni a majdani munkahelyek elvárásait.

Jelenleg nincsenek becsatornázott módszerek arra, hogyan tudja a munkaerőpiac közvetíteni az igényeit a felsőoktatás felé. A probléma sokrétüsége abban is megmutatkozik, hogy a felsőoktatás feladata elvileg nem az aktuális munkaerőpiacra, hanem a jövőbenire felkészíteni a hallgatóit. Ezen kívül az említett szakokhoz kapcsolódó munkaerőpiac is nagyon heterogén. Magasabb szinteken az ágazati egyeztető tanácsokon, szakmai szervezeteken, kerekasztalokon keresztül lehetne felmérni a jelenlegi helyzetet, a jövőbeli helyzet feltérképezéséhez pedig hasznos lehet figyelembe venni a különbözö gazdaságkutatók elörejelzéseit arra vonatkozóan, hogy milyen lesz a munkaerő szakképzettsége, az informatikai képzettség jelentősége, a mobilitás, a munkaerőpótlás migráció révén. Nem szabad megfeledkezni a technológiai fejlődésről és az infrastruktúra fejlődéséről sem. Ennek teljes feldolgozása túlmutat ennek a dolgozatnak a keretein.

Hogy mégis valami bepillantást nyerjek legalább a jelenlegi helyzetbe, az alumni kutatást választottam, mert a munkáltatók többnyire közép és nagyvállalatok, ahol nehéz megtalálni azt a konkrét személyt, aki választ tudna adni a kérdéseinkre. Próbálkozhatnánk az 
emberi erőforrás részleg munkatársaival, akik az új kollégák kiválasztásával foglalkoznak, de személyes beszélgetések alapján az a tapasztalatom, hogy a napi szinten felmerülő informatikai feladatokról nekik is csak a saját munkaterületük kapcsán van elképzelésük. Felsőoktatásban gyakori példa az alumnival való kapcsolattartás, amelynek egyik célja lehet a gyakorlatorientált képzés kialakításának elősegítése is. A korábban végzett hallgatók tudják elmondani, hogy ők mit tapasztaltak azokban a munkakörökben, ahol a nálunk szerzett diplomával tudtak elhelyezkedni.

Az ÁVF végzettjei körében a Karrieriroda közreműködésével végeztem kérdőíves kutatást 2012 februárjában. Ez egy kísérleti kutatás volt, ami arra irányult, hogy jobban körül tudjam határolni, hogy pontosan mi is szerepeljen a további kutatásokban. Ebben a kérdöívben nagyon sok kérdés volt, ennek köszönhetően mintázatokat tudtam keresni a válaszok között. A tanulságok alapján állítottam össze azt a rövidebb kérdőívet, amit 2013 novemberében a BCE gazdaságtudományok alapszakjain végzett diplomásokkal terveztem kitöltetni. A 2012-es eredmények alapján alakítottam ki a V.1. fejezetben bemutatott kutatások kérdőívét is a bejövő hallgatók informatikai előismereteire vonatkozóan. A BCE végzettjeit végül a teljes 2013-14-es tanév alatt kerestem meg különböző elektronikus utakon. A kísérleti kutatás tanulságait és a BCE végzettjei körében folytatott kutatást a V.4. fejezetben mutatom be. 


\section{KUTATÁSI EREDMÉNYEK}

\section{V.1. Tantervelemzések}

\section{V.1.1. A 2010-e kutatás menete}

A 2010 nyarán folytatott tantervelemzések során 21 intézmény (11 egyetem és 10 főiskola) 65 szakjának 244 tantárgyát tudtam bevonni a vizsgálatba. A különböző szakokon tanított azonos tárgyakat leszámítva 131 különböző tantárgy adatai álltak rendelkezésemre (előadások és gyakorlatok száma, kredit, számonkérés módja, felelős tanszék). A tantárgyi hálókat és a tantárgyleírásokat az intézmények honlapjáról gyüjtöttem, így sajnos az adataim nem teljes körüek.

Az adatok gyüjtésekor néhány egyszerüsítést alkalmaztam. A tárgyak besorolásánál csak kötelező, választható és szakiránytárgy kategóriákat használtam (utóbbinál nem tettem különbséget, hogy a szakirányon már kötelező, vagy ott is csak választható). Néhány intézménynél egyáltalán nem találtam választható tárgyakat, ami nem feltétlenül jelenti azt, hogy ott nem is hirdetnek, csak a honlapokon lévő információk hiányosak.

El kellett még döntenem, hogy mi alapján tekintek egy tárgyat informatika tárgynak, ezt általában a tárgy neve, esetleg leírása illetve a meghirdető tanszék alapján tudtam eldönteni.

17 intézmény 83 tárgyánál találtam tantárgyleírást is, bár nagyon különböző terjedelemben. A tantárgyleírások alapján szövegbányászati elven a tárgyak tartalmát is elemeztem és összehasonlítottam. [Tikk, 2007] Fogalommátrixot hoztam létre, melyben a dimenziók az egyes fogalmak (510 fogalmat gyüjtöttem ki, melyeket 51 kategóriába csoportosítottam), a vektorok az egyes tantárgyak, a koordináták 1 és0 aszerint, hogy az adott kategória az adott leírásban szerepel-e. Ezek alapján klaszteranalízissel vizsgáltam a tárgyak hasonlóságát.

\section{V.1.2. Eredmények, következtetések az operatív tantervekböl és tantárgyi adatlapokból}

Szakonként a kötelező tárgyak száma 1 és 6 között változott, átlag 2,01 kötelező informatika tárgyuk volt a hallgatóknak. Iskolán belül általában nagyobb volt a hasonlóság, mint szakokon belül, az intézményekben általában ugyanazok voltak a kötelező tárgyak 
a különböző szakokon, de a tantárgyak számában volt eltérés: a gazdálkodás és menedzsment szakon és a pénzügy és számvitel szakon többnyire több volt a kötelező informatika (átlag 2,5). A legkevesebb tárgy a közszolgálat szakirányon volt (átlag 1,4). Néhány helyen a gazdálkodás és menedzsmenten belül a szakirányok között szerepel információmenedzsment, itt szakiránytárgyként több informatika tárgy is szerepelt. A kötelező tárgyak kreditszáma 1 és 5 között változott, az óraszám hetente maximum 2 óra előadás vagy 4 óra gyakorlat, néhol vegyesen is voltak előadások és gyakorlatok.

A tárgyak tartalmát vizsgálva klaszteranalízissel (a csoporton belüli kapcsolatok módszerével) az alábbi csoportok alakultak ki a tárgyak között:

1. kezdő informatika tárgyak $(\mathrm{n}=8)$ : első évfolyamon kötelezö tárgyak, tartalmukban jellemzően alapismeretek, hardver, operációsrendszer ismeretek, sok elmélet, kevés irodai szoftver gyakorlat (szövegszerkesztés, táblázatkezelés, prezentációkészítés) szerepelt.

2. alap (haladóbb) informatika tárgyak $(n=2)$ : első évfolyamon kötelező tárgyak, az elméleti anyagban nincs operációsrendszer, viszont van adatvédelem, adatbiztonság, a gyakorlatban nincs szövegszerkesztés és prezentáció, csak táblázatkezelés, kiemelve a statisztikai feladatokat.

3. Hálózatos, webes tárgyak $(n=29)$ : nagy és igen vegyes csoport, jellemző tartalom: internetes alkalmazások, internetes adatgyüjtés, webszerkesztés, hálózatok, multimédia, kiadványszerkesztés. Mélységükben különböző tárgyak. Kötelező, választható és szakiránytárgyak is vannak köztük.

4. vállalatirányítási és egyéb informatikai rendszerek ( $n=28)$ : szintén nagy, de egységesebb csoport. Különböző, gyakran szakspecifikus (számviteli, emberi erőforrás, logisztikai) informatikai rendszereket bemutató tárgyak. Többnyire választható, vagy szakiránytárgy, csak egy negyede szerepel kötelező tárgyként.

5. modellező tárgyak $(\mathrm{n}=5)$ : általában haladó táblázatkezelés, statisztikai, matematikai, pénzügyi modellek, valóban gazdasági felhasználás. 2 kötelező és 3 választható tárgy került ebbe a csoportba.

6. adatbázis-kezelés ( $\mathrm{n}=10)$ : némelyik tárgy információrendszer név alatt fut, de valójában azok tartalma is adatbázis-kezelés. Az adatbázis-tervezés elmélete mellett gyakorlati ismeretekkel, gyakran az SQL nyelv használatával. 4 kötelező, 4 választható és 2 szakiránytárgy. 
7. egyetlen kötelező tárgy külön csoportba került, mert nagyon átfogó, majdnem mindenről szól (az 51 kategóriából 24-et bejelöltem, míg a többi tárgynál az átlag 6,29, a leggyakoribb érték 4 volt.)

A tantárgyak elnevezéséböl nagyon korlátozottan lehet csak a tárgyak tartalmára következtetni, azonos csoporton belül is számtalan teljesen különböző elnevezésü tantárgy szerepelt, és hasonló elnevezésü tárgyak is egészen eltérő tartalmakat takartak.

Várakozásom szerint a teljes kutatás lefolytatása után kialakuló tananyagban a következő eltérések lesznek a fent vázoltakhoz képest:

1. Az első csoportban lévő tárgyak tartalmának nagy része nem szükséges: részben középiskolai, alapműveltségi tananyag, részben szintén középiskolai gyakorlati anyag (szövegszerkesztés, prezentációkészítés), bár némelyik tárgyleírás felsorol haladóbb ismereteket is, részben müszaki informatika, így nem releváns a közgazdászok számára. A gyakorlat az 5. és 6. csoport tárgyai felé fog közelíteni, az elméleti anyag pedig a 4 . csoport tárgyai felé.

2. A harmadik csoportban lévő tárgyak mélysége nagyon változatos, részben szintén középiskolai tananyag (HTML), így ezek egy része szintén nem szükséges, részben viszont hasznos, szakirányú tananyagok, amit nagyobb hangsúllyal lehet szerepeltetni.

3. A negyedik, ötödik, hatodik csoport tartalmaz leginkább szakmaspecifikus és a középiskolai tananyagon túlmutató ismereteket, így a hangsúly ezek felé a tartalmak felé fog eltolódni.

\section{V.1.3. Informatika tárgyak a Budapesti Corvinus Egyetemen és az Általá- nos Vállalkozási Föiskolán}

Empirikus kutatásaim során az alcímben szereplő két intézményről gyüjtöttem információkat. A BCE az egyetlen hazai intézmény, amely mind a 9 szakot indítja. Az ÁVF egyike azoknak a főiskoláknak, melyek a gazdaságtudományok képzési területen is indítanak szakokat. Így alkalmam nyílik bemutatni, hogy milyen különbségek is beleférnek egy-egy szak képzési és kimeneti követelményei által meghatározott keretbe. Az ÁVFen 3 szak müködik: Gazdálkodás és menedzsment, Nemzetközi gazdálkodás, és kifutó módon Közszolgálati (az első két szak idei, a 3. szak 2009-es mintatantervét tudtam vizsgálni). 
Az egyetemen az informatika tárgyakat az Informatikai intézet tanszékei, a Számítástudományi tanszék, az Információrendszerek tanszék és az Infokommunikációs tanszék tartják. A föiskolán a Módszertani tanszékhez tartoznak az informatika tárgyak.

\section{V.1.3.1. Üzleti szakok}

A Budapesti Corvinus Egyetemen kisebb eltérésekkel 5 üzleti szakon egyformán folyik a képzés. Mind az öt a Gazdálkodástudományi Karon indul. A 6. üzleti szak (emberi eröforrások) a Közgazdaságtudományi Karon fut és informatika szempontjából jobban hasonlít a közgazdasági szakokhoz, ezért azt a következő alfejezetben mutatom be.

Kötelező tárgy: 1. félévben 4 kredit értékben, Informatika néven (Számítástudományi tanszék). Tartalmában elméleti ismeretek előadás formájában, és géptermi gyakorlatok, ahol táblázatkezelést tanulnak a hallgatók. Pénzügy és számvitel szakon a gyakorlatokon Excel programozás is van.

Kötelezően választható tárgy: 4. félévben 3 kredit értékben Üzleti Informatika néven (Információrendszerek tanszék). Tartalmában szemináriumi keretek között az IT üzleti alkalmazásának kategóriái, rendszertípusok, informatikával kapcsolatos alapvető vezetési és szervezési kérdéskörök megismerése, IT alkalmazásokkal támogatott munkavégzés csoportmunka környezetben, információkeresés és prezentálás, alapszintű problémamegoldó képesség informatikai kérdésekben. A mintatantervben szereplő 4 tárgy közül 3-at kell a hallgatóknak választani, tehát elméleti alapon 75\% az esélye, hogy egy hallgató ezt a tárgyat tanulja.

\section{Szakmai kötelező tárgyak és szakiránytárgyak:}

- Gazdálkodás és menedzsment szak: szakmai kötelező informatika tárgy 6. félévben 4 kreditért E-business néven. (Infokommunikációs tanszék). Egyetlen szakirány, a német nyelvű DSG szakirány tartalmaz informatika tárgyat: 4. félév, 3 kredit, Wirtschaftsinformatik (Számítástudományi tanszék)

- Nemzetközi gazdálkodás szak: egyáltalán nincs informatika tartalmú tárgy

- Kereskedelem és marketing: egyáltalán nincs informatika tartalmú tárgy

- Turizmus és vendéglátás: egyáltalán nincs informatika tartalmú tárgy

- Pénzügy és számvitel: kötelező szakmai tárgy a 4. félévben 3 kreditért a Pénzügyiszámviteli informatika I., és kötelezően választható szakmai tárgy pénzügy szakirányon és számvitel szakirányon is 5. félévben szintén 3 kreditért a Pénzügyiszámviteli informatika II. Mind a kettőt a Pénzügyi számvitel tanszék tartja. 
Választható tárgyak: mind az 5 szakon egyformán több informatika tárgy közül lehet választani. Wirtschaftsinformatik (3 kredit), Alkalmazott informatika - Üzleti modellek (4 kredit), Adatbáziskezelés a gyakorlatban (4 kredit) és Internet (4 kredit) a Számítástudományi tanszék gondozásában és Cases on Business IT Management (5 kredit) és Vállalati gazdálkodás támogatása SAP nagyvállalati megoldással (3 kredit) az Információrendszerek tanszék gondozásában.

Ehhez képest az ÁVF-en két üzleti szak van, a Gazdálkodás és menedzsment, illetve a Nemzetközi gazdálkodás.

Kötelező tárgyak: 2. félévben 3 kreditért Gazdaságinformatikai alapismeretek néven, tartalmában egy bevezető előadás után gyakorlatban prezentációkészítés, táblázatkezelés és szövegszerkesztés. 3. félévben szintén 3 kreditért Gazdaságinformatikai alkalmazások néven, tartalmában egy bevezető előadás után gyakorlatban adatbázis-kezelés, kapcsolat a különböző irodai szoftverek között, Excel makrók

\section{Szakiránytárgyak:}

- Nemzetközi gazdálkodás szak: egyáltalán nincs informatika tartalmú tárgy

- Gazdálkodás és menedzsment szak: a 7 lehetséges főszakirány közül 3-ban van informatika, de mindegyiket a szaktanszék tartja: Humán erőforrás szakirányon Humán informatika 5. félévben 3 kreditért (Alkalmazott magatartástudományi tanszék), Kontrolling szakirány: Kontrolling információs rendszer 6. félév 5 kredit (Pénzügytani és számviteli tanszék) és Logisztika szakirány: Logisztikai információs rendszerek 6. félév 3 kredit (Vállalkozás-menedzsment tanszék). A 8 lehetséges mellékszakirányból 2-ben van informatika: E-business szakirányon Internet stratégiák és Internet és üzletvitel, mindkettő a 6. félévben 2 illetve 4 kredit. Médiatechnológia szakirányon szintén a 6. félévben 2 kreditért Számítógépes kiadványszerkesztés (Marketing és kommunikáció tanszék)

Szabadon választható tárgy: a 4. félévtől kezdve 3 kreditért Excel haladóknak illetve Integrált vállalatirányítási rendszerek.

Fakultatív tárgy: 2 kreditért Internet. Csak a kötelezően teljesített kreditek fölött lehet teljesíteni költségtérítés fejében. 


\section{V.1.3.2. Közgazdasági szakok és Emberi erőforrások szak}

A Budapesti Corvinus Egyetemen a 3 közgazdasági szak és az emberi erőforrások szak a Közgazdaságtudományi karon van. Ezek mintatanterve informatika szempontjából hasonló, ezért csoportosítottam én is így.

Kötelező tárgyak: 1. félévben 4 kredit értékben, Informatika I. néven (Számítástudományi tanszék). Tartalmában elméleti ismeretek előadás formájában, és géptermi gyakorlatok, ahol táblázatkezelést és Excel programozást tanulnak a hallgatók, illetve Gazdaságelemzés szakon a programozás helyett a Maple programot ismerik meg.

Csak az Emberi erőforrások szakon 2. félévben 3 kredit értékben Üzleti Informatika néven (Információrendszerek tanszék). Tartalmában szemináriumi keretek között az IT üzleti alkalmazásának kategóriái, rendszertípusok, informatikával kapcsolatos alapvető vezetési és szervezési kérdéskörök megismerése, IT alkalmazásokkal támogatott munkavégzés csoportmunka környezetben, információkeresés és prezentálás, alapszintủ problémamegoldó képesség informatikai kérdésekben.

Kötelező szaktárgy: Csak az Emberi erőforrások szakon van ilyen. 5. félévben, 3 kredit értékben Személyügyi informatika néven (Információrendszerek tanszék).

Választható szaktárgy: Csak Gazdaságelemzés és Közszolgálati szakon, 4. vagy 6. félévben, 3 kredit értékben Informatika II. néven (Számítástudományi tanszék). A két szakon a tárgy tartalma nem ugyanaz. Közszolgálati szakon csak elöadás az informatikai rendszerek vállalati környezetben történő felhasználásáról, míg a Gazdaságelemzés szakon csak gyakorlat szerepel a tárgyban, ahol Excel programozás és további Maple ismeretek szerepelnek.

Választható tárgyak: a különböző szakokon egyes tárgyak besorolása eltérő, így a korábban ismertetett tárgyak egy része néhány szakon választható tárgyként szerepel. Így az Üzleti informatika az Alkalmazott közgazdaságtan, a Gazdaságelemzés és a Közszolgálati szakon, az Informatika II. (előadásos változat) az Alkalmazott közgazdaságtan és az Emberi erőforrások szakon. Egyedül az Alkalmazott közgazdaságtan szakon szerepel a Programozási gyakorlatok (LaTex és MATLAB) nevű gyakorlati tárgy 6 kreditért (Matematika tanszék).

A fentieken kívül mind a 4 szaknál szerepel az üzleti szakoknál ismertetett 3 választható tárgy: Alkalmazott informatika - Üzleti modellek, Adatbázis-kezelés a gyakorlatban és 
Internet a Számítástudományi tanszék gondozásában, de az ott ismertetettől eltérően darabja nem 4 kreditért, hanem 2 részletben meghirdetve összesen 6 kreditért. Pl. Adatbáziskezelés a gyakorlatban I. és Adatbázis-kezelés a gyakorlatban II. A két rész csak együtt vehető fel, de külön osztályzatot kapnak a hallgatók.

Ezekhez képest az ÁVF-en egyedül Közszolgálati szak van, az is kifutóban. Nekik ugyanaz a két kötelező tárgyuk van, mint a Gazdálkodás és menedzsment, valamint a Nemzetközi gazdálkodás szakosoknak, azaz Gazdaságinformatikai alapismeretek és Gazdaságinformatikai alkalmazások 3-3 kreditért az első és a második félévben.

Ezen kívül az 5. félévben van még egy kötelező módszertani tárgyuk 3 kreditért Kutatásmódszertan, szakdolgozat készítés néven.

Választható tárgyként egyedül az Integrált vállalatirányítási rendszerek szerepel a 4. félévtől 3 kreditért.

Megállapítható, hogy a 2010-es felméréshez hasonlóan most is nagyobb hasonlóság mutatkozik intézményen belül (akár a két kart is külön intézménynek tekintve), mint szakok között. Az egyetemen kevesebb a kötelező gyakorlati oktatás informatikából, ugyanakkor jóval szélesebb a választható tárgyak köre. A Gazdálkodás és menedzsment szakon viszont a főiskolán úgy tünik nagyobb hangsúlyt fektetnek a szakirányspecifikus, a munkahelyen közvetlenül alkalmazható informatikai ismeretek átadására.

\section{V.1.4. Európai példák áttekintése}

A fejezet elején fontosnak tartom leszögezni, hogy az itt bemutatott példák csak egy-egy kiragadott megoldást mutatnak a nagyon széleskörü lehetőségek közül, melyeket Európa egyetemein alkalmaznak. A magyar gyakorlattal való összehasonlítást nehezíti, hogy bár a kimenet oldalon valószínüleg azonos célok állnak - a felsőoktatásba kerülő hallgatók informatikai előképzettsége nem azonos. Ennek teljes körü feltárása túlmutatna ennek a dolgozatnak a keretein.

\section{V.1.4.1. Aston Egyetem, Anglia}

Az Aston Business School a következő alapszakokat indítja [http://www.aston.ac.uk/study/undergraduate/courses/school/aston-business-school]:

- Accounting for Management (Számvitel)

- Business \& Management (Gazdálkodás és menedzsment)

- Business Computing \& IT (Gazdaságinformatika) 
- Economics \& Management (Közgazdaságtan és gazdálkodás)

- Finance (Pénzügy)

- Human Resource Management (Emberi erőforrás)

- International Business \& Management (Nemzetközi gazdálkodás)

- International Business \& Economics (Nemzetközi közgazdaságtan)

- Marketing (Marketing)

Ezek közül a Nemzetközi közgazdaságtan kivételével mindegyik szak első évfolyamán van legalább 1, jellemzően 2 alapozó informatika tárgy. A gazdálkodás és menedzsment szakon 3. A gazdaságinformatika szakon természetesen további IT tárgyak is szerepelnek, melyek választható tárgyként a többi szakról is elérhetőek. Mindegyik kurzus 5 kredites. A minden szakon futó tárgy: Information technology in business (BN1160) - Üzleti információ technológia.

A következő két tárgy közül általában az egyik, a gazdálkodás és menedzsment szakon mindkettő szerepel az elsős tárgyak között:Foundations of business analytics (BN1115) - Az üzleti elemzés alapjai és Introduction to business analytics (BN1116) - Bevezetés az üzleti elemzésbe.

Az érdeklődőknek ajánlott további tárgyak:

- Doing e-Business (BN2285) - E-business

- SystemsAnalysis (BN2228/9) - Rendszerelemzés

- Decision Support Systems (BN2231) - Döntéstámogató rendszerek

- IT \& Web Development (BN2234) - IT és webfejlesztés

- Databases (BN2237) - Adatbázisok

- Advanced Spreadsheet Systems (BN2226) - Haladó táblázatkezelö rendszerek

- Operational Research 1 (BN2290) - Operációkutatás 1.

- Operational Research 2 (BN2288) - Operációkutatás 2.

- Management Science Methods (BN2288) - Menedzsment tudomány módszertana Az alábbiakban rövid áttekintést nyújtok a kötelező tárgyak tanulási eredményeiröl (Module Learning Outcomes). 


\section{Information technology in business (BN1160) - Üzleti információ technológia:}

Szakmai képességek:

- Megfelelő eszközök használata az üzleti információ hatékony megtalálására, kiválasztására és prezentálására.

Szellemi képességek:

- Képes az általános üzleti problémákra megfelelő technikai megoldásokat meghatározni.

- Megfelelő szakkifejezésekkel és fogalmakkal képes elmagyarázni, hogy hogyan és miért használnak információs rendszereket az üzleti életben.

- Képes elmagyarázni az információs rendszerek társadalomra gyakorolt hatását, megfelelő erkölcsi, etikai, jogi, szakmai és környezetvédelmi fogalmakat, szakkifejezéseket és példákat használva.

Ismeret és megértés:

- Az adat és információ természete és jelentősége olyan területeken müködő szervezetek számára, mint például a döntéshozatal.

- Hogyan fejlesztik a szoftver alkalmazásokat.

- Jogi, erkölcsi, etikai témák, melyek a szervezetekben használt technológiához kapcsolódnak.

Továbbvihető képességek:

- Képes változatos szoftver alkalmazásokat használni üzleti célokra, mint például egyszerü vezetői döntések modellezése és elemzése egy táblázatkezelő csomaggal.

\section{Foundations of business analytics (BN1115) - Az üzleti elemzés alapjai:}

Szakmai képességek:

- Táblázatok, diagramok és grafikonok használata és interpretálása.

- Numerikus adatok elemzése, trendek meghatározása és elemző eszközök használata a döntéshozói folyamat segítésére. 
Szellemi képességek:

- Képes elmagyarázni a különböző adatokból nyert változatos összesítő statisztika jelentését.

- Képes széleskörü forrásokból származó adatok elemzésére és interpretálásra.

- Megfelelö matematikai és statisztikai módszereket használ jól meghatározott problémák megoldására és releváns következtetéseket von le.

Ismeret és megértés:

- Jól ismeri az adatokat és képes megkülönböztetni a különböző adattípusokat.

- Megfelelő matematikai modellt alkot egyszerü és jól meghatározott problémák megoldására.

- Kiszámolja egy esemény valószínüségét a valószínűség-számítás szabályait használva és ezeket üzleti szituációban döntési fáknál alkalmazza.

- Kiszámolja a nettó jelenértéket és elmagyarázza a kamatszámítások alapelveit.

- A megfelelő statisztikai technikákat alkalmazva hipotézist fogalmaz meg, és teszteli azt.

- Megérti az egyszerü lineáris regresszió alapelveit és képes interpretálni a kulcsstatisztikákat a regressziós egyenletből.

Továbbvihető képességek:

- Egyszerü üzleti kontextusban szemlélteti a számítási és statisztikai képességét.

- Az Excel és on-line eszközök alap használata különböző matematikai és statisztikai számításokhoz.

\section{Introduction to business analytics (BN1116) - Bevezetés az üzleti elemzésbe:}

Szakmai képességek:

- Bizonyítja alapvető képességeit egyszerü üzleti helyzetek matematikai modelljeinek megalkotására és megoldására.

Szellemi képességek:

- Azonosítja és alkalmazza az adatgyüjtés és elemzés megfelelő statisztikai módszereit. 
- Azonosítja, hogy hol használhatók a különböző valószínűség-számítási módszerek az üzleti döntések modellezésére, és alkalmazásukkal kiszámítja a különböző kimenetek valószínüségét.

Ismeret és megértés:

- Függvények és statisztikai adatok grafikonjait és diagramjait megrajzolja és interpretálja.

- Kiszámolja egy esemény valószínüségét a valószínüség-számítás szabályait használva és ezeket üzleti szituációban döntési fáknál alkalmazza.

- Az SPSS statisztikai programcsomag használatával hipotézist fogalmaz meg, és teszteli azt.

Továbbvihető képességek:

- Bemutatja az adatokat üzleti hallgatóság számára.

\section{V.1.4.2. Maribori Egyetem, Szlovénia}

A alapképzésben a Economic and Business Sciences (Gazdaság és üzleti tudományok) szakon első évben kötelező tárgy: Introduction to Business Information Systems (5 ECTS) - Bevezetés a gazdasági informatikába. A szakon a kötelező első éves tárgyak elvégzése után lehet a 8 lehetséges szakirány közül választani. A szakirányok között van E-business is, ahol a szakiránytárgyak között természetesen több informatika tárgy is szerepel. A többi szakirány tárgyai között csak a Business Management and Organisation szakon találtam utolsó félévben a Management Information Systems 7 kredites tárgyat. A választható tárgyakról nem találtam információt.

[http://www.epf.uni-mb.si/default.aspx]

A kötelező tárgy tartalma:

Bevezetés az információs rendszerekbe, információs rendszerek típusai, információs rendszerek az üzleti folyamat szemszögéből, a vezetői folyamat szemszögéből, bevezetés a számítógépesített adatfeldolgozásba, műveleti szintű alkalmazások, vezetői szintű alkalmazások, e-business alkalmazások, bevezetés a számítógéprendszerekbe (szerverek és munkaállomások), bevezetés a rendszer szoftverekbe, számítógép-hálózatokba, információs rendszerek elemzésébe és tervezésébe, végfelhasználói számítástechnika. 
Célok: a kurzusnak két fó célja van: - bemutatni az informatika alapjait és elérni a személyi számítógép használatának képességét. A kurzus első részében a szervezetek információs rendszerének szerepére, az információs rendszerek architektúrájának alapjaira, a különféle információs technológiák alapvető jellemzőire és azok szervezeten belüli használatára és az információs rendszerek felépítésének alapvető módszereire koncentrál. A második rész fókusza a legfontosabb személyi számítógépes eszközök megtanulása.

Kulcskompetenciák és egyéb jellemzők: információs rendszer alapok és képesség a személyi számítógép használatára.

Szándékolt tanulási eredmények: Ismeret és megértés: információs rendszerek alapjai, számítógépesített adatfeldolgozás alapjai, információ technológiák alapjai, információs rendszerek elemzésének és tervezésének alapjai, a legfontosabb személyi számítógépes eszközök használata.

\section{V.1.5. A tantervelemzések összefoglalása}

A 2010-es felmérés során az áttekintett tananyagok nagyon változatos képet mutattak. Fontos a szakok közötti különbség és jogos az iskolák közötti különbség is, hiszen gyakran más a munkahelyi célcsoport. Markánsan jelen voltak a tananyagokban az informatika tudományának bevezetését célzó tartalmak, amit a jelenlegi középiskolai tananyag mellett el lehetne hagyni és helyette a haladóbb és szakmaspecifikusabb tartalmakkal megtölteni a tárgyakat.

A 2013-ban végzett vizsgálat egyik érdekes tanulsága, hogy a BCE-n választható tárgyként az összes szakon megjelenő 3 informatika tárgy a G kar szakjainak 4, míg a K kar szakjainak $2 * 3$, azaz 6 kreditet ér. A tárgyak tartalma, számonkérése, a rá fordítandó munka viszont nem különbözik. Ez hibátlan példája annak, hogy a kreditek jelentése nem az a magyar felsőoktatásban, amire az ki lett találva.

A külföldi példák is azt mutatják, hogy Európában sem alakult ki egységes kezelése a IT kompetenciák tantervesítésének. A két általam megvizsgált egyetemen különböző óraszámban, kreditértékkel és különböző tartalommal szerepelnek informatika tárgyak. Találtam a jelenlegi hazai gyakorlathoz hasonló, alap ismereteket tartalmazó modulokat, ugyanakkor olyan megoldást is, ahol az adatok elemzése, és a matematikai modellek és statisztikai számítások voltak inkább hangsúlyosak. Jellemző volt a vállalati információs rendszerek szerepeltetése is a tananyagban. 


\section{V.2. Bejövő hallgatók felmérése}

\section{V.2.1. A kutatások menete}

A bejövő hallgatók megkérdezése 3 tanévben is megtörtént a 7. táblázat összehasonlításban mutatja a 3 kutatás jellemzőit. A felmérésekben nem csak a gazdaságtudományok képzési terület hallgatói vettek részt, ezt az összehasonlító elemzésnél figyelembe vettem.

\section{V.2.2. A 2012-es és a 2013-as kutatás eredményei}

A kérdőívben a felhasználói ismeretek egyes részterületeire kérdeztem rá kétféle skálán. Minden területről meg kellett adnia a válaszadónak, hogy milyen szinten szerepelt a középiskolai tanulmányaiban és hogy saját megítélése szerint milyen szintűek az ismeretei. A területek között a szövegszerkesztés és a táblázatkezelés részletekre bontva is szerepelt, mert tapasztalataink alapján ez a két terület a legfontosabb és leggyakrabban tanított a felsőoktatásban. A két témakör felbontása egy korábbi kísérleti kutatás eredményének megfelelően történt melynek bemutatása a V.4. fejezetben is szerepel.[Baksa-Haskó, 2012] A többi témakör megjelölésénél egyrészt figyelembe vettük az ECDL vizsgák moduljait [ECDL, 2009a,b,c,d,e,f,g , másrészt a 2005-06-os kutatás kategóriáit az összehasonlíthatóság miatt. Ennek megfelelően a megkérdezett témaköröket a 8. táblázat mutatja.

A lehetséges válaszok a tanítással kapcsolatban: részletesen tanították (2), érintőlegesen volt róla szó (1), egyáltalán nem tanították (0). A lehetséges válaszok a tudással kapcsolatban: segítség nélkül, rutinosan tudok feladatot megoldani (2), ismereteim hiányosak, csak segítséggel tudok feladatot megoldani (1), nem ismerem (0).

Számunkra (a felsőoktatásban informatikát tanítók számára) elsősorban a tudásszintek az érdekesek, így ezt a 15 változót vontam be elsősorban a vizsgálatba. A kutatás viszont lehetőséget nyújt arra is, hogy a tudást befolyásoló tényezőket azonosítsuk. Ezek között várhatóan magas magyarázóerővel bír, hogy tanították-e az adott területet, de érdekes lehet megvilágítani más tényezők hatását, mutató erejét is. 
DOI: $10.14267 /$ phd.2014081

7. táblázat $A$ bejövő hallgatók 3 felmérésének összehasonlítása

\begin{tabular}{|c|c|c|c|}
\hline & 2005-2006 & 2012 & 2013 \\
\hline Intézmények & $\mathrm{BCE}$ & $\mathrm{BCE}, \mathrm{A} V \mathrm{~F}, \mathrm{BKF}$ & $\mathrm{BCE}$ \\
\hline $\begin{array}{l}\text { Képzési } \\
\text { területek és } \\
\text { szakok }\end{array}$ & $\begin{array}{l}\text { Gazdálkodás- } \\
\text { tani szak } \\
\text { Gazdaság- } \\
\text { informatikus } \\
\text { szak }\end{array}$ & $\begin{array}{l}\text { Gazdaságtudományok: } \\
\text { alkalmazott közgazdaságtan (BCE) } \\
\text { emberi erőforrások (BCE) } \\
\text { gazdálkodási és menedzsment (BCE, } \\
\text { ÁVF, BKF) } \\
\text { kereskedelem és marketing (BCE, } \\
\text { BKF) } \\
\text { közszolgálati (ÁVF) } \\
\text { nemzetközi gazdálkodás (BCE, ÁVF, } \\
\text { BKF) } \\
\text { pénzügy és számvitel (BCE) } \\
\text { turizmus és vendéglátás (BCE, BKF) } \\
\text { Társadalomtudományi: } \\
\text { kommunikáció és médiatudomány } \\
\text { (BKF) } \\
\text { nemzetközi tanulmányok (ÁVF, } \\
\text { BKF) } \\
\text { Informatika: } \\
\text { gazdaságinformatikus (BCE) } \\
\text { Kereskedelmi menedzser felsőfokú } \\
\text { szakképzés: } \\
\text { nemzetközi szállítmányozási és } \\
\text { logisztikai szakügyintéző (ÁVF) } \\
\text { reklámszervezö szakmenedzser } \\
\text { (ÁVF) } \\
\text { üzleti szakmenedzser (ÁVF) }\end{array}$ & $\begin{array}{l}\text { Gazdaságtudományok: } \\
\text { alkalmazott közgazdaságtan } \\
\text { emberi erőforrások } \\
\text { gazdálkodási és } \\
\text { menedzsment } \\
\text { gazdaságelemzés } \\
\text { kereskedelem és marketing } \\
\text { közszolgálati } \\
\text { nemzetközi gazdálkodás } \\
\text { pénzügy és számvitel } \\
\text { turizmus és vendéglátás } \\
\text { Informatika: } \\
\text { gazdaságinformatikus }\end{array}$ \\
\hline $\begin{array}{l}\text { Képzési } \\
\text { forma }\end{array}$ & nappali & nappali és levelező & nappali és levelező \\
\hline $\begin{array}{l}\text { Kitöltési } \\
\text { arány }\end{array}$ & $\begin{array}{l}92 \% \\
\text { (a kérdések } \\
\text { egy része csak } \\
\text { a második } \\
\text { félévben } \\
\text { szerepelt, } \\
40 \% \text { ) }\end{array}$ & $\begin{array}{l}\text { BCE nappali 46\% } \\
\text { ÁVF nappali 94\% } \\
\text { ÁVF levelező 94\% } \\
\text { BKF nappali 95\% } \\
\text { BKF levelező 37\% }\end{array}$ & $\begin{array}{l}\text { BCE nappali } 61 \% \\
\text { BCE levelező 58\% }\end{array}$ \\
\hline $\begin{array}{l}\text { A vizsgálat } \\
\text { területei }\end{array}$ & $\begin{array}{l}\text { 1. félév: } \\
\text { tanították-e az } \\
\text { egyes } \\
\text { informatikai } \\
\text { területeket } \\
\text { 2. félév: } \\
\text { tanították-e az } \\
\text { egyes } \\
\text { informatikai } \\
\text { területeket és } \\
\text { milyen } \\
\text { szintünek érzi } \\
\text { az ismereteit }\end{array}$ & $\begin{array}{l}\text { tanították-e az egyes informatikai } \\
\text { területeket és milyen szintünek érzi } \\
\text { az ismereteit }\end{array}$ & $\begin{array}{l}\text { tanították-e az egyes } \\
\text { informatikai területeket és } \\
\text { milyen szintünek érzi az } \\
\text { ismereteit } \\
+ \text { teszt az ismeretek } \\
\text { szintjének felmérésére }\end{array}$ \\
\hline $\begin{array}{l}\text { A kitöltés } \\
\text { módja }\end{array}$ & $\begin{array}{l}\text { elektronikusan } \\
\text { tanórán }\end{array}$ & $\begin{array}{l}\text { elektronikusan tanórán vagy otthon } \\
\text { (BCE), elektronikusan tanórán (BKF) } \\
\text { és papíron beiratkozáskor (ÁVF) }\end{array}$ & $\begin{array}{l}\text { elektronikusan otthon, } \\
\text { pontszám ösztönzéssel }\end{array}$ \\
\hline
\end{tabular}


DOI: $10.14267 /$ phd.2014081

8. táblázat A 2012-es és a 13-as kutatásban megkérdezett témakörök

\begin{tabular}{|c|c|c|}
\hline MEGKÉRDEZETT TÉMAKÖRÖK & $\begin{array}{l}\text { ÉRETTSÉGI } \\
\text { KÖVETEL- } \\
\text { MÉNY }\end{array}$ & $\begin{array}{c}\text { ECDL } \\
\text { ALAPMODUL } \\
\text { KÖVETELMÉNY }\end{array}$ \\
\hline $\begin{array}{l}\text { 1. Szövegszerkesztővel egyszerü szöveg készítése } \\
\text { (írás, módosítás, helyesírás ellenőrzés, } \\
\text { karakterformázás, bekezdésformázás, felsorolás, } \\
\text { tabulátor, táblázat, oldalbeállítás, oldalszámozás, } \\
\text { nyomtatás) }\end{array}$ & Igen & Igen \\
\hline $\begin{array}{l}\text { 2. Szövegszerkesztővel hosszú dokumentum } \\
\text { készítése (címsorok, tartalomjegyzék, szakaszok, } \\
\text { hasábok, lábjegyzet) }\end{array}$ & Nem & Nem \\
\hline $\begin{array}{l}\text { 3. Szövegszerkesztővel kiadvány (pl. plakát, } \\
\text { meghívó) készítése (sablonok, stíluskészletek, } \\
\text { szövegdobozok, szegélyek, képek, rajzok) }\end{array}$ & Nem & Igen \\
\hline $\begin{array}{l}\text { 4. Szövegszerkesztő haladó használata (körlevél, } \\
\text { ürlap, kereszthivatkozás, tárgymutató, jelszavas } \\
\text { védelem, makrók használata) }\end{array}$ & Nem & $\begin{array}{c}\text { csak a } \\
\text { körlevél }\end{array}$ \\
\hline $\begin{array}{l}\text { 5. Táblázatkezelővel táblázat készítése (adatbevitel, } \\
\text { szám és dátumformátumok, rendezés, másolás, } \\
\text { kitöltés, cellaformázás, nyomtatás) }\end{array}$ & Igen & Igen \\
\hline $\begin{array}{l}\text { 6. Táblázatkezelővel egyszerü képletek, függvények } \\
\text { használata (abszolút-relatív hivatkozás, } \\
\text { statisztikai függvények, AUTOSZUM, HA, } \\
\text { DARABTELI) }\end{array}$ & Igen & Igen \\
\hline $\begin{array}{l}\text { 7. Táblázatkezelővel haladó függvények (kereső, } \\
\text { dátum, szöveg, pénzügyi, logikai függvények } \\
\text { használata, függvények egymásba ágyazása) }\end{array}$ & Nem & Nem \\
\hline $\begin{array}{l}\text { 8. Táblázatkezelővel adatok elemzése (diagramok, } \\
\text { feltételes formázás, autoszürő, kimutatás) }\end{array}$ & Igen & Igen \\
\hline $\begin{array}{l}\text { 9. Táblázatkezelő haladó használata } \\
\text { (cellaérvényesítés, Solver, makrók) }\end{array}$ & Nem & Nem \\
\hline 10. Prezentációkészítés & Igen & Igen \\
\hline $\begin{array}{l}\text { 11. Internethasználat (levelezés, közösségi oldalak, } \\
\text { fórumok, információkeresés) }\end{array}$ & Igen & Igen \\
\hline 12. Webszerkesztés (HTML, PHP stb.) & Igen & Nem \\
\hline $\begin{array}{l}\text { 13. Multimédia szerkesztés (képszerkesztés, videó } \\
\text { szerkesztés) }\end{array}$ & Nem & Nem \\
\hline 14. Adatbázis-kezelés & Igen & Igen \\
\hline 15. Programozás & Nem & Nem \\
\hline
\end{tabular}




\section{V.2.2.1. Részminták elemzése}

Mivel az egyes felmérésekben használt minták több szempontból almintákra bonthatók, a további elemzések előtt megvizsgáltam az alminták egyezőségét-különbözőségét. A 2012-es felmérésben megkérdezett hallgatók 3 különböző intézménybe járnak és 4 különböző tudományterülethez tartozó szakon tanulnak. A 4 tudományterület a gazdaságtudomány, a társadalomtudomány, az informatika és külön soroltam a felsőfokú szakképzésben kereskedelmi menedzser szakokra járó hallgatókat. (Az 5., agrár területen összesen 7 hallgató volt a válaszadók között, ezt a kis elemszám miatt kihagytam az elemzésből). Vannak közöttük teljes idős és részidős képzésben részt vevők. A kitöltők aránya a 9. táblázatban látható.

9. táblázat A 2012-13-as előismereti kérdőív kitöltési arányai az egyes intézményekben az egyes képzési területeken részidős $(R)$ és nappalis $(N)$ képzésben

\begin{tabular}{|c|c|c|c|c|c|c|c|c|c|c|}
\hline \multirow{2}{*}{$\begin{array}{c}\text { KÉPZÉSI } \\
\text { TERÜLETEK }\end{array}$} & & \multicolumn{3}{|c|}{ ÁVF } & \multicolumn{2}{|c|}{ BCE } & \multicolumn{3}{|c|}{ BKF } & \multirow{2}{*}{ VÉGÖSSZEG } \\
\hline & & $\mathbf{R}$ & $\mathbf{N}$ & Össz & $\mathbf{N}$ & ÖSSZ & $\mathbf{R}$ & $\mathbf{N}$ & Össz & \\
\hline \multirow{3}{*}{$\begin{array}{l}\text { gazdaság- } \\
\text { tudomány }\end{array}$} & kitöltö & 90 & 84 & 174 & 431 & 431 & 50 & 393 & 443 & 1048 \\
\hline & össz & 92 & 87 & 179 & 936 & 936 & 137 & 406 & 543 & 1658 \\
\hline & arány & $98 \%$ & $97 \%$ & $97 \%$ & $46 \%$ & $46 \%$ & $36 \%$ & $97 \%$ & $82 \%$ & $63 \%$ \\
\hline \multirow{3}{*}{$\begin{array}{l}\text { társadalom- } \\
\text { tudomány }\end{array}$} & kitöltő & 9 & 40 & 49 & & & 23 & 182 & 205 & 254 \\
\hline & össz & 15 & 40 & 55 & & & 60 & 201 & 261 & 316 \\
\hline & arány & $60 \%$ & $\begin{array}{r}100 \\
\%\end{array}$ & $89 \%$ & & & $38 \%$ & $91 \%$ & $79 \%$ & $80 \%$ \\
\hline \multirow{3}{*}{$\begin{array}{l}\text { kereskedelmi } \\
\text { menedzser } \\
\text { felsőfokú } \\
\text { szakképzés }\end{array}$} & kitöltő & & $\overline{44}$ & $\overline{44}$ & & & & & & 44 \\
\hline & össz & & 51 & 51 & & & & & & 51 \\
\hline & arány & & $86 \%$ & $86 \%$ & & & & & & $86 \%$ \\
\hline \multirow{3}{*}{ informatika } & kitöltö & & & & 88 & 88 & & & & 88 \\
\hline & össz & & & & 197 & 197 & & & & 197 \\
\hline & arány & & & & $45 \%$ & $45 \%$ & & & & $45 \%$ \\
\hline \multirow{3}{*}{ Végösszeg } & kitöltő & 99 & 168 & 267 & 519 & 519 & 73 & 575 & 648 & 1434 \\
\hline & össz & 107 & 178 & 285 & 1133 & 1133 & 197 & 607 & 804 & 2222 \\
\hline & arány & $93 \%$ & $94 \%$ & $94 \%$ & $46 \%$ & $46 \%$ & $37 \%$ & $95 \%$ & $81 \%$ & $65 \%$ \\
\hline
\end{tabular}

Mivel 2013-ban csak a Budapesti Corvinus Egyetem hallgatói között végeztük el a felmérést, itt csak a gazdaságtani képzési területen hasonlítottam össze a nappalis és a rész- 
idős képzésre járó hallgatók részmintáit. A válaszadók között esti tagozatosok nem voltak, csak levelezősök. (Az elemzésből egyelőre a gazdaságinformatikusokat teljesen kihagytam)

A részminták összehasonlításának feltétele a változók normális eloszlása. A változóink nyers állapotban nagyrészt ferde eloszlást mutatnak, így sem a szóráselemzés, sem az independent t próba nem alkalmazható rájuk.

Mivel a tudásszint felmérése önbevalláson alapult, indokoltnak tünt az értékek transzformálása az egyéni átlagoktól való eltérésre, így az egyéni általános önértékelésbeli különbségek kiszürhetőek. A transzformált változók eloszlása már normálisnak tekinthető. Mivel a szórásazonosság így sem teljesül, az independent t próbát alkalmaztam a részminták páronkénti összevetésére.

Az elemzésben mindenütt 5\%-os szignifikancia szintet vettem alapul.

Az eltérések elemzésénél nem szabad megfeledkeznünk arról, hogy nem az eredeti, nyers változókat, hanem az egyedi átlagtól való eltérést elemezzük.

\section{Képzési területek részmintáinak elemzése (2012)}

Képzési területenként a következő eltéréseket találtam: a gazdaságinformatikus szakosok szignifikánsan különböztek mindhárom másik képzési területen tanulóktól a legtöbb területen.

A szövegszerkesztővel egyszerü szövegek készítésében (1), a táblázatkezelő haladó szintű használatában (7) és az internethasználatban (11) mindegyiknél szignifikánsan gyengébbek, a táblázatkezelővel egyszerü képletek készítésében (6), haladó függvények használatában (7) és elemzések készítésében (8) viszont mindegyik más tudományterületen tanulóknál erősebbek. A gazdaság és a társadalomtudományi területen tanulókkal szemben multimédia szerkesztésben (13) is gyengébbek, adatbázis-kezelésben (14) viszont erősebbek. A többi területen - így prezentációkészítésben (10), webszerkesztésben (12) és programozásban (14) sem - nem mutatkozott szignifikáns eltérés.

A felsőfokú szakképzésben tanulók jobbnak ítélik a tudásukat táblázatkezelővel adatok elemzésében (8), mint a gazdaságtudományi és a társadalomtudományi szakokra járók. Lemaradásuk van viszont a gazdaságtudományi szakosokkal szemben táblázatok készítésében (5) és prezentációkészítésben (10), valamint a társadalomtudományi szakosokkal 
szemben multimédia szerkesztésben (13). Az összes többi vizsgált területen nincs szignifikáns eltérés a szakcsoportok között.

A gazdaságtudományi és társadalomtudományi területeken tanulókat összehasonlítva táblázatok készítésében (5) és egyszerü képletek használatában (6) az előbbieknek, míg a szövegszerkesztés a táblázatkezelő haladó használatában (4) (9) és multimédia szerkesztésben (13) az utóbbiaknak van előnye. A többi kérdésre adott válaszban az eltérés nem szignifikáns.

Megállapítható tehát, hogy a legtöbb eltérést az informatika szakosok mutatják a többi szakkal szemben.

Mivel találtam szignifikáns eltérést minden képzési terület pár között, valamint a különböző intézményekben nem mindegyik képzési területről voltak hallgatók a vizsgálatban, a további elemzésben csak a gazdaságtudományi szakosok válaszait vettem figyelembe.

\section{Nappalis és részidős képzésre járók részmintái (2012)}

Következő lépésben a nappali tagozatos és a részidős képzésben résztvevő hallgatók ismereteit hasonlítottam össze. A 15 kérdésből 6-ra adott válaszoknál itt is szignifikáns eltérést találtam. A nappalisok értenek jobban a prezentációkészítéshez (10), a webszerkesztéshez (12) és a multimédiaszerkesztéshez (13). A másik három területen: szövegszerkesztő és táblázatkezelő haladó használata (4) (9) és táblázatkezelőben haladó függvények használata (7), viszont a részidős képzésben résztvevők ítélték jobbnak a tudásukat.

A különbségek oka az lehet, hogy a részidős képzésben résztvevők között nagyobb arányban vannak, akik a középiskolában még kevesebb, vagy semennyi informatikai ismeretet szereztek, viszont a munkájuk során már rutint szereztek bizonyos feladattípusokban.

\section{Nappali és levelező képzésre járók részmintái (2013)}

A 2012-es felméréshez képest találtam hasonlóságot és eltérést is. A prezentációkészítés (10) és a webszerkesztés (12) ebben az évben is szignifikánsan jobb volt a nappalisok bevallásában, de a multimédiaszerkesztés (13) már nem mutatott szignifikáns eltérést. A levelezőre járók a 2012-es eredményekhez hasonlóan magasabb tudásról számoltak be a szövegszerkesztő és a táblázatkezelő haladó használatánál (4) (9). A táblázatkezelő haladó függvények használatánál (7) nem volt szignifikáns eltérés, de az egy évvel korábbihoz képest a táblázatkezelővel adatok elemzésében (8) szignifikánsan jobbnak vallották magukat. 
Az eltérések magyarázata ugyanúgy a levelezős hallgatók eltérő tapasztalataiban keresendö. A 2012-ben megállapított 6 szignifikáns eltérésből 4 ebben az évben is kimutatható volt.

\section{Intézményenkénti részminták elemzése (2012)}

Az intézmények összehasonlításánál csak a nappalis gazdaságtudományi területen hallgatók válaszait hasonlítottam össze, mert erről volt adatom mindhárom intézményben. Itt szintén több szignifikánsan eltérő válaszcsoportot találtam.

A két főiskola között alig mutatkozik különbség, az internethasználatban (11) a BKF diákjainak értékei a magasabbak, táblázatkezelővel adatelemzésben (8) pedig az ÁVF-en tanulóké.

A BCE hallgatóinak válaszai több helyen is eltérnek a két föiskolától. Mindkét iskola hallgatóinál jobbak saját bevallásuk alapján táblázatkezelővel egyszerü képletek szerkesztésében (6) és prezentációkészítésben (10). Mindkettőnél gyengébbek a szövegszerkesztő és a táblázatkezelő haladó használatában (4) (9). A BKF hallgatóinál jobbak a válaszaik alapján még a hosszú dokumentumok szerkesztésében (2) és a táblázat készítésben (5), gyengébbek viszont internethasználatban (11) és webszerkesztésben (12).

A további elemzések csak a BCE gazdaságtudományi nappali tagozatos hallgatóira vonatkoznak.

\section{V.2.2.2. Adatok elemzése}

Mivel az értékeket a saját válaszok átlagától vett eltérésre transzformáltuk, a pozitív számok azt mutatják, hogy az adott területet a hallgatók az átlagos tudásuknál jobban, míg a negatív értékek azt, hogy kevésbé tudják. A 10. ábra diagramjain az átlagok csökkenő sorrendjében láthatók a nappali tagozatos gazdaságtudományi képzési területen tanuló 2012-ben első évfolyamos BCE hallgatók válaszainak eloszlásai, a 10. táblázatban pedig az egyes változók mutatói mind a 2012-es, mind a 2013-as adatok alapján.

Látható, hogy a sorrend megegyezik (egyetlen eltérés, hogy a szövegszerkesztő haladó használata eggyel lejjebb került a listán) és az értékek sem térnek el jelentősen egymástól a két felmérésben. A legmagasabb pozitív értékeket az internethasználat kapta, ezt követte a szövegszerkesztővel egyszerü szöveg szerkesztése és a prezentációkészítés. Többnyire pozitív, de 0-hoz közelebbi értékeket kapott még a szövegszerkesztővel hosszú dokumentum és kiadvány szerkesztése, a táblázatkezelővel táblázat és egyszerü képletek 
készítése. A programozás és a táblázatkezelő haladó használata kapta a legkisebb értékeket.
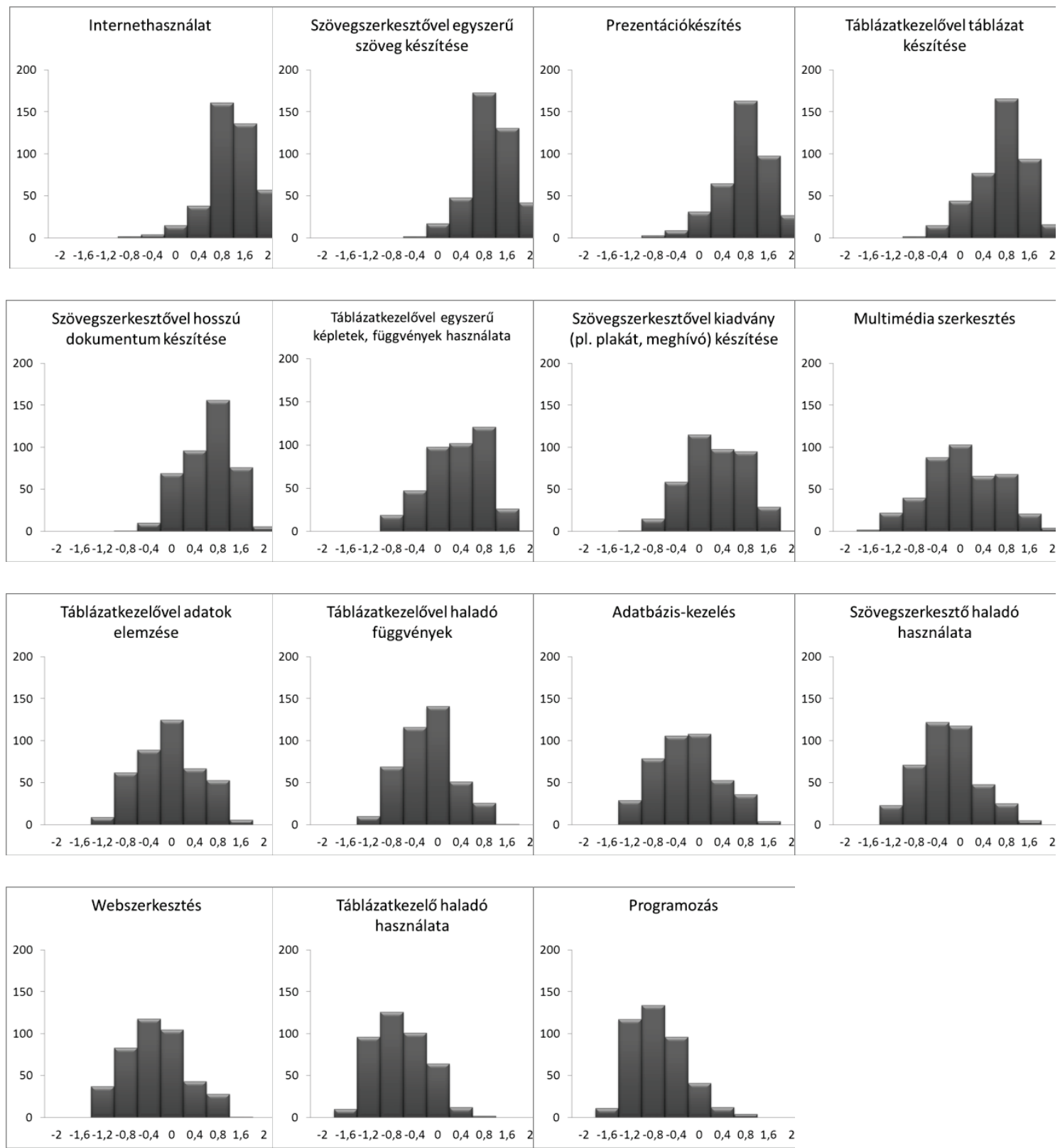

10. ábra A Budapesti Corvinus Egyetem nappali tagozatos gazdaságtudományi szakos hallgatóinak tudásszintje saját bevallásuk alapján a saját átlagukhoz képest. (Saját szerkesztés) 
DOI: $10.14267 /$ phd.2014081

10. táblázat A BCE gazdaságtudományi nappali szakos hallgatóinak mutatói (saját szerkesztés)

\begin{tabular}{|c|c|c|c|c|c|c|}
\hline \multirow[b]{2}{*}{ VÁLTOZó } & \multicolumn{3}{|c|}{2012} & \multicolumn{3}{|c|}{2013} \\
\hline & $\mathbf{N}$ & ÁTLAG & SZÓRÁS & $\mathbf{N}$ & ÁTLAG & SZÓRÁS \\
\hline Internethasználat(saját átlagtól) & 414 & 0,81 & 0,41 & 560 & 0,86 & 0,40 \\
\hline $\begin{array}{l}\text { Szövegszerkesztővel egyszerü szö- } \\
\text { veg készítése (saját átlagtól) }\end{array}$ & 414 & 0,77 & 0,37 & 562 & 0,80 & 0,37 \\
\hline Prezentációkészítés(saját átlagtól) & 396 & 0,62 & 0,44 & 544 & 0,73 & 0,43 \\
\hline $\begin{array}{l}\text { Táblázatkezelővel táblázat készí- } \\
\text { tése(saját átlagtól) }\end{array}$ & 414 & 0,55 & 0,45 & 562 & 0,64 & 0,41 \\
\hline $\begin{array}{l}\text { Szövegszerkesztővel hosszú doku- } \\
\text { mentum készítése(saját átlagtól) }\end{array}$ & 414 & 0,47 & 0,42 & 564 & 0,43 & 0,42 \\
\hline $\begin{array}{l}\text { Táblázatkezelővel egyszerü képle- } \\
\text { tek, függvények használata(saját át- } \\
\text { lagtól) }\end{array}$ & 414 & 0,18 & 0,50 & 562 & 0,16 & 0,49 \\
\hline $\begin{array}{l}\text { Szövegszerkesztővel kiadvány (pl. } \\
\text { plakát, meghívó) készítése(saját át- } \\
\text { lagtól) }\end{array}$ & 413 & 0,12 & 0,50 & 563 & 0,12 & 0,50 \\
\hline $\begin{array}{l}\text { Multimédia szerkesztés(saját átlag- } \\
\text { tól) }\end{array}$ & 414 & $-0,13$ & 0,64 & 565 & $-0,07$ & 0,59 \\
\hline $\begin{array}{l}\text { Táblázatkezelővel adatok elem- } \\
\text { zése(saját átlagtól) }\end{array}$ & 411 & $-0,21$ & 0,53 & 563 & $-0,28$ & 0,51 \\
\hline $\begin{array}{l}\text { Táblázatkezelővel haladó függvé- } \\
\text { nyek(saját átlagtól) }\end{array}$ & 414 & $-0,33$ & 0,45 & 562 & $-0,33$ & 0,47 \\
\hline Adatbázis-kezelés(saját átlagtól) & 415 & $-0,36$ & 0,54 & 563 & $-0,40$ & 0,54 \\
\hline $\begin{array}{l}\text { Szövegszerkesztő haladó haszná- } \\
\text { lata(saját átlagtól) }\end{array}$ & 412 & $-0,37$ & 0,50 & 565 & $-0,45$ & 0,46 \\
\hline Webszerkesztés(saját átlagtól) & 415 & $-0,43$ & 0,51 & 564 & $-0,42$ & 0,52 \\
\hline $\begin{array}{l}\text { Táblázatkezelö haladó haszná- } \\
\text { lata(saját átlagtól) }\end{array}$ & 411 & $-0,80$ & 0,47 & 563 & $-0,86$ & 0,42 \\
\hline Programozás(saját átlagtól) & 415 & $-0,87$ & 0,46 & 565 & $-0,90$ & 0,41 \\
\hline
\end{tabular}

\section{Összefüggés a középiskolai tananyaggal}

Izgalmas megvizsgálni az összefüggést az egyes területek tanítottsága és tudása között.

A 3. táblázat mutatja a korrelációt az egyes területeken. Az összefüggés az internethasználat kivételével mindenütt szignifikáns, de az erősség területenként változik, és sehol nem mondható túl magasnak. Az összefüggés gyengeségének két oka lehet. Egyrészt vannak olyan területek (például a programozás), ahol a tanítás ellenére sokan úgy érzik, hogy nem tudják, másrészt több területen az egyéb forrásból szerzett ismeretek kipótolják az iskolai hiányosságokat (tipikusan ilyen az internet használat). A felsőoktatásban lévő hallgatók internethasználatát vizsgáló, több évet és több intézmény átfogó kutatásból is kiderül, hogy időről időre a hallgatók nagyobb aránya használja az internetet aktívan már a felsőoktatásba kerülés előtt. [Vig, 2005; 2008] 
11. táblázat A Budapesti Corvinus Egyetem nappali tagozatos gazdaságtudományi szakos hallgatóinak tudásszintjének és az adott terület középiskolai tananyagban szereplésének összefüggése a kapcsolat szorossága szerint csökkenő sorrendben (saját szerkesztés)

\begin{tabular}{|l|c|c|c|c|}
\hline & \multicolumn{2}{|c|}{$\mathbf{2 0 1 2}$} & \multicolumn{2}{c|}{$\mathbf{2 0 1 3}$} \\
\hline \multicolumn{1}{|c|}{ VÁLTOzó } & $\begin{array}{c}\text { PEARSON } \\
\text { CORR. }\end{array}$ & $\begin{array}{c}\text { SIG. } \\
\text { (2-TAILED) }\end{array}$ & $\begin{array}{c}\text { PEARSON } \\
\text { CORR. }\end{array}$ & $\begin{array}{c}\text { SIG. } \\
\text { (2-TAILED) }\end{array}$ \\
\hline Adatbázis-kezelés(saját átlagtól) & 0,615 & 0,00 & 0,612 & 0,00 \\
\hline $\begin{array}{l}\text { Táblázatkezelóvel adatok elem- } \\
\text { zése(saját átlagtól) }\end{array}$ & 0,550 & 0,00 & 0,494 & 0,00 \\
\hline $\begin{array}{l}\text { Táblázatkezelővel egyszerü képle- } \\
\text { tek, függvények használata(saját } \\
\text { átlagtól) }\end{array}$ & 0,496 & 0,00 & 0,505 & 0,00 \\
\hline Webszerkesztés(saját átlagtól) & 0,464 & 0,00 & 0,448 & 0,00 \\
\hline $\begin{array}{l}\text { Táblázatkezelóvel haladó függvé- } \\
\text { nyek(saját átlagtól) }\end{array}$ & 0,412 & 0,00 & 0,468 & 0,00 \\
\hline Programozás(saját átlagtól) & 0,380 & 0,00 & 0,273 & 0,00 \\
\hline $\begin{array}{l}\text { Szövegszerkesztő haladó haszná- } \\
\text { lata(saját átlagtól) }\end{array}$ & 0,361 & 0,00 & 0,441 & 0,00 \\
\hline $\begin{array}{l}\text { Szövegszerkesztővel kiadvány (pl. } \\
\text { plakát, meghívó) készítése(saját át- } \\
\text { lagtól) }\end{array}$ & 0,360 & 0,00 & 0,390 & 0,00 \\
\hline $\begin{array}{l}\text { Táblázatkezelóvel táblázat készí- } \\
\text { tése(saját átlagtól) }\end{array}$ & 0,356 & 0,00 & 0,300 & 0,00 \\
\hline $\begin{array}{l}\text { Táblázatkezelö haladó haszná- } \\
\text { lata(saját átlagtól) }\end{array}$ & 0,314 & 0,00 & 0,293 & 0,00 \\
\hline Prezentációkészítés(saját átlagtól) & 0,285 & 0,00 & 0,272 & 0,00 \\
\hline $\begin{array}{l}\text { Multimédia szerkesztés(saját átlag- } \\
\text { tól) }\end{array}$ & 0,208 & 0,00 & 0,306 & 0,00 \\
\hline $\begin{array}{l}\text { Szövegszerkesztővel hosszú doku- } \\
\text { mentum készítése(saját átlagtól) }\end{array}$ & 0,149 & 0,00 & 0,239 & 0,00 \\
\hline $\begin{array}{l}\text { Szövegszerkesztővel egyszerü szö- } \\
\text { veg készítése (saját átlagtól) }\end{array}$ & 0,138 & 0,00 & 0,102 & 0,02 \\
\hline Internethasználat(saját átlagtól) & $-0,050$ & 0,31 & $-0,049$ & 0,28 \\
\hline
\end{tabular}

A 2013-as kutatásban a levelezős hallgatóknál is megvizsgáltam az összefüggést a középiskolai tananyaggal. Azzal az előzetes feltételezéssel éltem, hogy náluk kisebb lesz az összefüggés. A feltételezésem annyiban beigazolódott, hogy a leginkább alaptudáshoz sorolható területek nem mutattak összefüggést azzal, hogy a középiskolai tananyagban mennyire fordultak elő, sőt az internethasználat negatív kapcsolatot mutatott, a szövegszerkesztővel egyszerű szöveg és hosszú dokumentumok készítése, a táblázatkezelővel 
táblázat készítése és a prezentációkészítés viszont függetlennek bizonyult. A másik 10 területet a 12. táblázat tanúsága szerint viszont hasonló képet mutatott, mint a nappalisoknál.

12. táblázat A Budapesti Corvinus Egyetem levelező tagozatos gazdaságtudományi szakos hallgatóinak tudásszintjének és az adott terület középiskolai tananyagban szereplésének összefüggése a kapcsolat szorossága szerint csökkenő sorrendben 2013-ban (saját szerkesztés)

\begin{tabular}{|l|c|c|}
\hline \multicolumn{1}{|c|}{ VÁLTozó } & \multicolumn{2}{c|}{$\mathbf{2 0 1 3}$} \\
\hline & $\begin{array}{c}\text { PEARSON } \\
\text { CORR. }\end{array}$ & $\begin{array}{c}\text { SIG. } \\
\text { (2-TAILED) }\end{array}$ \\
\hline Táblázatkezelö haladó használata(saját átlagtól) & 0,57 & 0,00 \\
\hline Adatbázis-kezelés(saját átlagtól) & 0,50 & 0,00 \\
\hline $\begin{array}{l}\text { Táblázatkezelővel egyszerü képletek, függvények haszná- } \\
\text { lata(saját átlagtól) }\end{array}$ & 0,46 & 0,00 \\
\hline Szövegszerkesztő haladó használata(saját átlagtól) & 0,44 & 0,00 \\
\hline Programozás(saját átlagtól) & 0,44 & 0,00 \\
\hline Táblázatkezelővel adatok elemzése(saját átlagtól) & 0,43 & 0,00 \\
\hline Webszerkesztés(saját átlagtól) & 0,39 & 0,00 \\
\hline $\begin{array}{l}\text { Szövegszerkesztővel kiadvány (pl. plakát, meghívó) ké- } \\
\text { szítése(saját átlagtól) }\end{array}$ & 0,37 & 0,00 \\
\hline Táblázatkezelővel haladó függvények(saját átlagtól) & 0,34 & 0,00 \\
\hline Multimédia szerkesztés(saját átlagtól) & 0,29 & 0,01 \\
\hline
\end{tabular}

\section{Mit mutatnak a bizonyítványok}

Több felsőoktatási intézményben adnak részleges vagy teljes felmentést az informatika tárgyak látogatása alól ECDL bizonyítvány vagy informatika érettségi megléte alapján. Annak ellenőrzésére, hogy az egyes részterületeken van-e szignifikáns eltérés az ECDL alapmodulokból vizsgával rendelkező és nem rendelkező, illetve az informatika érettségivel rendelkező és nem rendelkező csoportok között, independent t próbát végeztem. A 11. ábrán látható, hogy a kétféle bizonyítvány megléte nem független egymástól. Az ECDL bizonyítvánnyal rendelkezők között magasabb az érettségivel is rendelkezők aránya.

Az ECDL alapvizsgákkal rendelkezők csoportja 2012-ben mindössze 3 területen mutatott szignifikáns összefüggést az egyes területek önbevallott tudásszintjével. Ezek közül is az egyik az internethasználat (11), amiben az ECDL vizsgával nem rendelkezők a jobbak. A két pozitív eltérés a táblázatkezelővel egyszerü képletek használatában (6) és az adatbázis-kezelésben van (14). 
A 2013-as felmérésben ettől valamelyest eltérő eredményeket kaptam, itt 7 területen volt összefüggés, de ebböl 5 volt kedvezőtlen a vizsgával rendelkezők tudására nézve $(1,9$, $11,13,15)$ és ugyanúgy csak két pozitív eltérést találtam. Az egyik ugyanúgy az adatbázis-kezelés (14), a másik pedig a táblázatkezelővel adatok elemzése (8).

Láthattuk, hogy az ECDL alapmodulok ennél jóval több területet tartalmaznak, de azokban nem voltak szignifikánsan jobbak a bizonyítvánnyal rendelkezők sem 2012-ben, sem 2013-ban $(1,3,4,5,10,11)$

Az érettségivel rendelkezők már több területen térnek el társaiktól 2012-ben. Negatív irányú az eltérés egyszerü szöveg készítésében (1) és a szövegszerkesztő haladó használatában (4), a táblázatkezelő haladó használatában (9), internethasználatban (11) és multimédia szerkesztésben (13). Pozitív az eltérés táblázatkezelővel táblázat készítésében (5) és adatelemzésben (8), webszerkesztésben (12) és adatbázis-kezelésben (14).

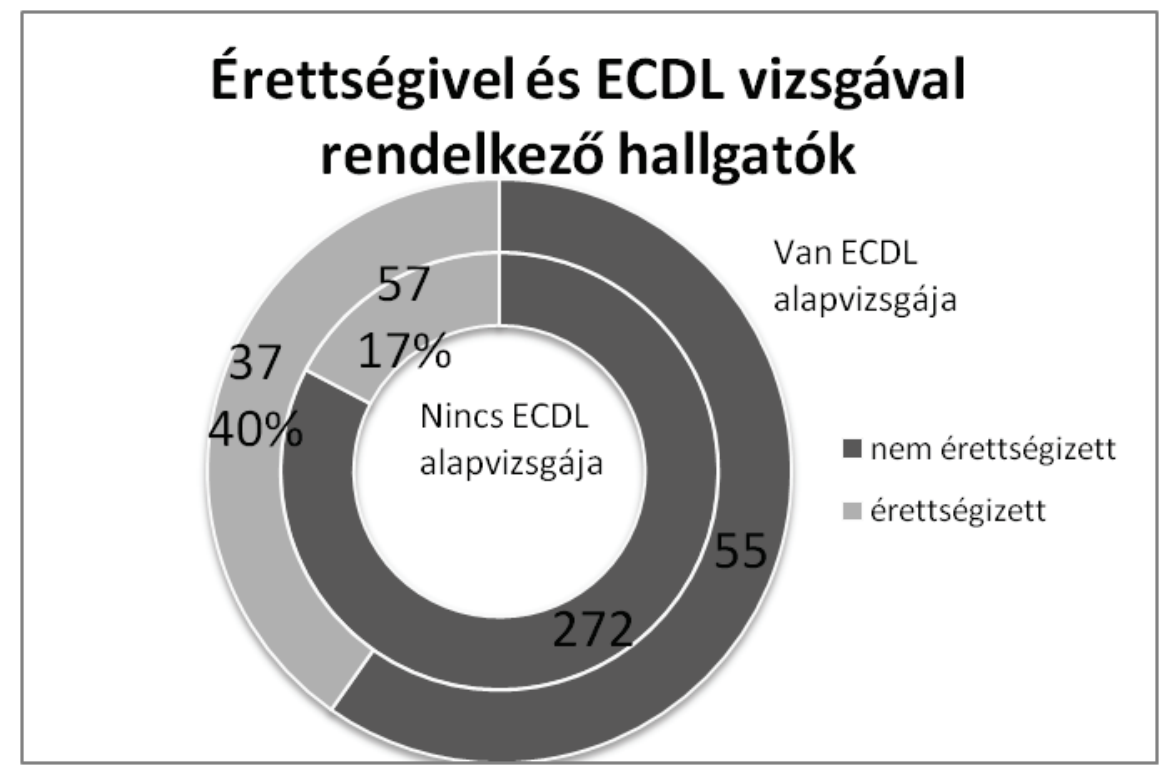

11. ábra A Budapesti Corvinus Egyetem nappali tagozatos gazdaságtudományi szakos hallgatóinak megoszlása ECDL alapvizsgák és informatika érettségi megléte szerint a 2012-es adatok alapján. (Saját szerkesztés)

2013-ban több területen mutatkozott eltérés. A negatív irányú eltérésben az előző évhez képest hiányzik a szövegszerkesztő haladó használata (4), abban itt nem mutatkozott szignifikáns különbség pluszba jött viszont a táblázat készítése (5), a prezentációkészítés(10)és a programozás (15). A pozitív irányú eltérésben megmaradt az adatelemzés (8) a webszerkesztés (12) és az adatbázis-kezelés (14), kimaradt a táblázatkezelővel táblázat készítése (ez negatívba váltott) (5), pluszba jött viszont a táblázatkezelővel egyszerű képletek, illetve a haladó függvények használata $(6,7)$. 
Az érettségi esetében is azt látjuk, hogy kevesebb területen mutatkozik pozitív eltérés, mint ahány területet érint a középszintü érettségi. Hiába része a követelményeknek, az érettségi bizonyítvánnyal rendelkezők nem szignifikánsan jobbak az 1, 10, 11 területeken. A kérdőíven meg kellett adni az érettségin szerzett osztályzatot is, ami a vizsgált hallgatók körében nagyon jó eredményekről árulkodott: elégséges nem volt egyik évben sem, közepes mindössze 3-3, jó 2012-ben 24 és 2013-ban 18, és a legtöbb jeles, 2012-ben 70 és 2013-ban 87 hallgató eredménye.

A két bizonyítványt összehasonlítva az érettségi megléte többet mond el a hallgatók tudásáról, mint az ECDL bizonyítvány.

\section{Néhány további érdekesség}

A 2013-as felmérésbe a korábbihoz képest bekerült egy plusz kérdés: „Milyen irodai programokat használ a Microsoft termékein kívül? (szövegszerkesztő, táblázatkezelő, prezentációkészítő) Sorolja fel vesszővel elválasztva. Ha csak Microsoft termékeket használ, akkor hagyja üresen.”

13. táblázat A Budapesti Corvinus Egyetem nappali tagozatos gazdaságtudományi szakos hallgatói által a Microsoft termékeken kívül használt programok említésszáma a 2013-ban (saját szerkesztés)

\begin{tabular}{|l|r|}
\hline \multicolumn{1}{|c|}{ ALKALMAZÁS } & EMLÍTÉSSZÁM \\
\hline Prezi & 24 \\
\hline OpenOffice & 12 \\
\hline Adobe Photoshop & 11 \\
\hline Numbers & 9 \\
\hline Pages & 9 \\
\hline Keynote & 8 \\
\hline Google Drive & 5 \\
\hline Adobe Reader & 4 \\
\hline GIMP & 4 \\
\hline LibreOffice & 4 \\
\hline
\end{tabular}

A gazdaságtudományi nappali szakok hallgatói közül 84-en válaszoltak a kérdésre (549ből, ez 15\%), akik válaszoltak, azok átlagosan 1,8 programot soroltak fel, bár többen programcsoportokat írtak, pl. LibreOffice. Összesen 50 különböző programot említettek, köztük a kérdésben sugallt szövegszerkesztő, táblázatkezelő és prezentációkészítő alkal- 
mazásokon kívül néhány médialejátszót, kép és videószerkesztőket és fájlkezelőket soroltak fel. Néhányan nem értették jól a kérdést, így felsoroltak Microsoft termékeket is. Voltak olyanok is, akik nem konkrét programneveket írtak, csak általános megnevezést, pl. táblázatkezelő vagy képszerkesztő.

A legtöbbször említett programok listája a 13. táblázatban látható. Megjelennek a nyílt forráskódú és a felhő alkalmazások is. A lista elején a Prezi prezentációkészítő szerepel, de a teljes mintához képest nagyon alacsony az említésszám, mindössze 4,37\%.

14. táblázat A Budapesti Corvinus Egyetem levelező tagozatos gazdaságtudományi szakos hallgatói által a Microsoft termékeken kívül használt programok említésszáma a 2013-ban (saját szerkesztés)

\begin{tabular}{|l|r|}
\hline \multicolumn{1}{|c|}{ ALKALMAZÁS } & EMLÍTÉSSZÁM \\
\hline AdobePhotoshop & 6 \\
\hline Prezi & 6 \\
\hline SAP & 4 \\
\hline AdobeReader & 3 \\
\hline AutoCAD & 3 \\
\hline OpenOffice & 2 \\
\hline ArchiCAD & 2 \\
\hline InDesign & 2 \\
\hline itunes & 2 \\
\hline LibreOffice & 2 \\
\hline Lotus Notes & \\
\hline
\end{tabular}

Megvizsgáltam a levelezős hallgatók válaszait is. Náluk 31-en válaszoltak a kérdésre (ez 103 hallgatóból 30\%), átlagosan 2,4 programot említve meg. A legnépszerübb említések között itt is szerepel a Prezi (5,82\%) és az Adobe Photoshop (5,82\%). Az SAP, mint az egyik legismertebb vállalatirányítási szoftver a nappalisoknál 3, a levelezősöknél 4 említést kapott. Mindkét listában szerepeltek további vállalati programok is, pl. számlázó program, illetve a levelezőknél CAD programokat is említettek, ahogy ez a A gazdaságtudományi nappali szakok hallgatói közül 84-en válaszoltak a kérdésre (549-böl, ez 15\%), akik válaszoltak, azok átlagosan 1,8 programot soroltak fel, bár többen programcsoportokat írtak, pl. LibreOffice. Összesen 50 különböző programot említettek, köztük a kérdésben sugallt szövegszerkesztő, táblázatkezelő és prezentációkészítő alkalmazásokon 
kívül néhány médialejátszót, kép és videószerkesztőket és fájlkezelőket soroltak fel. Néhányan nem értették jól a kérdést, így felsoroltak Microsoft termékeket is. Voltak olyanok is, akik nem konkrét programneveket írtak, csak általános megnevezést, pl. táblázatkezelő vagy képszerkesztő.

A legtöbbször említett programok listája a 13. táblázatban látható. Megjelennek a nyílt forráskódú és a felhő alkalmazások is. A lista elején a Prezi prezentációkészítő szerepel, de a teljes mintához képest nagyon alacsony az említésszám, mindössze 4,37\%.

14. táblázatban is látható.

A kérdőívben megkérdeztem azt is, hogy a középiskolán kívül hol tanultak még informatikai ismereteket. A 2013-as nappalis válaszok alapján 78,21\% már az általános iskolában is tanult, $43,76 \%$ barátoktól, családtól, $40,7 \%$ pedig autodidakta módon is tanult. A többi lehetőséget sokkal kisebb arányban jelölték meg: főiskolán, egyetemen $(5,1 \%)$, munkahelyen (2,81\%), magántanártól (2,28\%), tanfolyamon (1,93\%). Ugyanezek az opciók a levelezőknél egész más képet mutatnak. Náluk csak 48\% azok aránya, akik az általános iskolában is tanultak. Szintén viszonylag magas százalékban szerepel a barátok, család (39\%) és az autodidakta tanulás (59\%), de náluk magasabb arányban jelenik meg nyilvánvalóan a munkahely is (37\%) és a föiskolai vagy egyetemi tanulmányok is (35\%). A magántanár és a tanfolyam náluk is nagyon alacsony százalékban fordult elő ( $1 \%$ és $12 \%)$.

Mindkét megkérdezett csoport számottevő időt tölt számítógépes tevékenységgel a 2013as választok alapján, a levelezősök többet, mint a nappalisok, ahogy ezt a15. táblázat is mutatja.

15. táblázat A Budapesti Corvinus Egyetem nappali és levelező tagozatos gazdaságtudományi szakos elsős hallgatóinak számítógépes tevékenységgel töltött ideje 2013-ban (saját szerkesztés)

\begin{tabular}{|l|r|r|r|r|}
\hline \multirow{2}{*}{} & \multicolumn{2}{|c|}{ NAPPALI } & \multicolumn{2}{c|}{ LEVELEZÖ } \\
\cline { 2 - 5 } & \multicolumn{1}{|c|}{ Fö } & SZÁZALÉK & \multicolumn{1}{|c|}{ Fó } & SZÁZALÉK \\
\hline Napi 4 óránál többet & 157 & $27,59 \%$ & 71 & $68,93 \%$ \\
\hline Napi néhány órát & 363 & $63,80 \%$ & 28 & $27,18 \%$ \\
\hline Heti néhány órát & 43 & $7,56 \%$ & 2 & $1,94 \%$ \\
\hline Heti egy órát & 0 & $0,00 \%$ & 1 & $0,97 \%$ \\
\hline Kevesebbet & 2 & $0,35 \%$ & 1 & $0,97 \%$ \\
\hline
\end{tabular}




\section{V.2.3. A 2005-06-os és a 2012-es kutatási eredmények összehasonlítása}

Az összehasonlításba csak a Budapesti Corvinus Egyetem gazdaságtudományok szakos nappalis hallgatóit vettem bele. A korábbi kutatásból is kihagytam az akkori gazdaságinformatikus hallgatókat. A korábbi kutatás két félévben zajlott, nem teljesen egyforma kérdőívvel, így bizonyos információk a teljes megkérdezett sokaságra rendelkezésre állnak ( $\mathrm{n}=930$, az akkori elsős hallgatók 92\%-a), mások csak a második félévben megkérdezett hallgatókra ( $\mathrm{n}=406$, az akkori elsős hallgatók 40\%-a).

A 2012-es eredményekkel való összevetéshez néhány adatot transzformálnom kellett. Egyrészt a korábbi felmérésben az egyes területek tanítottságát csak kétfokozatú skálán kérdeztük (igen-nem), ezért az új adatokat úgy számoltam át, hogy igennek vettem az 1 és 2 értékü válaszokat is. Másrészt a 7 tanévvel korábbi kérdőíven a szövegszerkesztés és a táblázatkezelés csak egy-egy kérdésként szerepelt, így az újabb eredmények 4, illetve 5 változójából egyet-egyet kellett készíteni. A tanítottságnál a változók értékének maximumát vettem. A tudás megítélésénél nem vettem bele az összes idei változót az összehasonlításba, mert a maximum számítással felül, az átlagszámítással viszont alul becsültem volna azt a választ, amit akkor kaptunk volna, ha idén is csak egyetlen kérdés szerepel. Ehelyett szövegszerkesztésnél az egyszerü szöveg készítését és a hosszú dokumentum szerkesztését átlagoltam, táblázatkezelésnél pedig a táblázatkészítést, az egyszerü képleteket és az adatelemzést. Az összehasonlításnál a nyers értékeket (nem az átlagoktól való eltéréseket) vettem figyelembe.

A két év közötti különbségeket mutatja a 12. ábra. Láthatjuk, hogy a legtöbb területen jelentősen nőtt azok aránya, akiknek tanították. Egyetlen kivétel a programozás, melynek aránya 28\%-ról 23\%-ra csökkent. A korábban is magas arányban szereplő szövegszerkesztés a 88\%-ról majdnem maximumra, 98\%-ra emelkedett. A legnagyobb arányú növekedés a webszerkesztésnél és az adatbázis-kezelésnél tapasztalható, ahol 23 illetve 24\%-ról több mint két és félszeresére, 61\%-ra emelkedett azok aránya, akiknek szerepelt a középiskolai informatika tananyagában. 


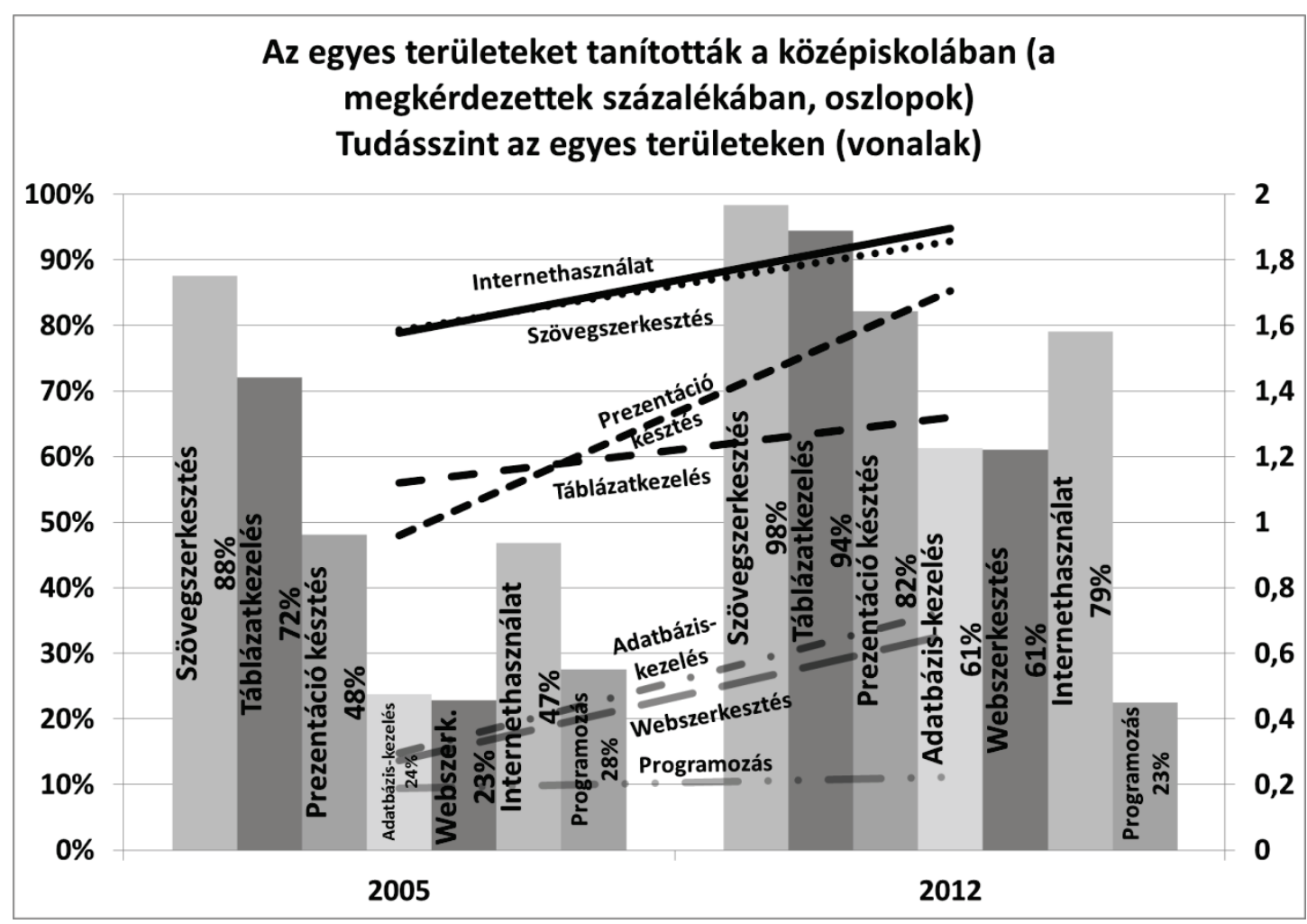

12. ábra A Budapesti Corvinus Egyetemet a 2005-06-os tanévben illetve a 2012-13-as tanévben kezdő nappali tagozatos hallgatóinak tudásszintje, illetve az egyes területek középiskolai tanítottságának aránya.(Saját szerkesztés)

Az előzetes várakozásoknak megfelelő emelkedések mellett a programozás előfordulásának csökkenése is könnyen indokolható, hiszen az informatika egyre inkább felhasználói irányba mozdul. A következő években várható a programozás további csökkenése a középiskolai tananyagban.

A tudásszintek vonalai is minden területen emelkedést mutatnak, de eltérő meredekséggel. Jól láthatóan a prezentáció készítés tudása nőtt meg leginkább, sorrendben is megelőzve a táblázatkezelést. Első két helyen volt és maradt fej-fej mellett az internethasználat és a szövegszerkesztés. Itt is a programozás kullog a sor végén, majdnem azonos szinten maradva a két időpont között.

\section{V.2.4. A 2013-as kutatás eredményei a vélt és valós tudás összehasonlí- tásával kapcsolatban}

A 2013-as kérdőív végén néhány tesztkérdés is szerepelt annak vizsgálatára, hogy az önbevallott tudás vajon milyen viszonyban van a valódi tudással. Mivel a teszt kitöltésének nem volt semmi tétje, valószínüsíthető, hogy tényleg a valódi tudásuk alapján töltötték ki a hallgatók. A teszt kérdései nem fedik le egyik vizsgált területet sem, inkább csak próba 
jelleggel kérdeznek rá egy-egy részletre. A disszertációban nem is elemezem az összes kérdést, csak néhány érdekesebb eredményt szeretnék kiemelni.

Mivel itt az önbevallás jóságára vagyok kíváncsi, az eredeti változókat fogom az elemzésekben használni, és nem az egyéni átlagoktól vett eltéréseket, mint az előzőekben, valamint a nappalis és levelezős hallgatókat együtt vizsgálom.

Az első kérdés így szólt: „Melyik billentyüvel lehet a kurzortól jobbra lévő karaktert törölni?” Mivel a kérdés nyílt volt, semmiféle fogódzót nem adott a válaszra vonatkozóan. Az adott válaszok között a következő kategóriákat képeztem: a helyes válasz valamilyen formában (Del, Delete), kreatív megoldások (jobbra nyíl + backspace), akik bevallottan nem tudják a választ (kihúzták, kérdőjelet írtak) és a kategorikusan rossz választ adók (pl. backspace, tab). A kérdésre összesen 526-an válaszoltak egyáltalán, és ők 42 különböző választ adtak. A 440 jó válasz mellett (a válaszadók 83,65\%-a a kérdőív kitöltők 65,09\%-a) 4-en oldották meg kreatívan a kérdést, 37-en vallották be, hogy nem tudják és 45-en adtak teljesen rossz választ. A jó válasz adás nem mutat szignifikáns összefüggést azzal, hogy milyen választ adtak arra kérdésre, hogy mennyire boldogulnak jól szövegszerkesztővel egyszerủ szöveg készítésével (írás, módosítás, helyesírás ellenőrzés, karakterformázás, bekezdésformázás, felsorolás, tabulátor, táblázat, oldalbeállítás, oldalszámozás, nyomtatás)". Vizsgálva az egyéb kompetenciára vonatkozó válaszokat is, a jó válasz5\%-os szignifikancia szinten csak a prezentációkészítéssel mutat összefüggést, de ha megengedőbbek vagyunk, 10\%-os szignifikancia szinten a táblázatkezelővel egyszerü képletek és haladó függvények használatával kimutatható az összefüggés. Ez általánosságban azt jelenti, hogy inkább az általános informatikai kompetenciával van kapcsolatban.

A második kérdés kifejezetten alap szövegszerkesztési tudásra vonatkozott, ez látható a 13. ábraán. Itt a helyes válasz a 3., azaz „Az egész bekezdés sorkizárt lesz”. A 4. választ még meg lehet magyarázni igaznak, a többi válasz teljesen rossz. Helyes választ az 565 válaszadó mindössze 45,49\%-a adott, további 7,61\% adott elfogadható választ. Elég szomorú összevetve azzal, hogy önbevallás szerint a hallgatók $87 \%$ önállóan, rutinból tud szövegszerkesztővel egyszerü szövegeket készíteni(írás, módosítás, helyesírás ellenőrzés, karakterformázás, bekezdésformázás, felsorolás, tabulátor, táblázat, oldalbeállítás, oldalszámozás, nyomtatás). 
DOI: $10.14267 /$ phd.2014081

Ha a képen látható kurzorpozícióban megnyomom a ikont, akkor mi fog történni?

Összetett·tartományra· úgy·hivatkozunk, hogy·az· összefüggố.részek·jelöléseit|pontosvesszốvelválasztjuk·el.๘

Pl.:-A2;C2:F5; $\mathrm{H1}: \mathrm{I3.q}$

Kérem, válasszon egyet a felsoroltak közül!

A második sor jobbra fog igazodni

A második sor sorkizárt lesz

Az egész bekezdés sorkizárt lesz

Az elsô és a második sor sorkizárt lesz

Az egész bekezdés jobbra fog igazodni

Felsorolásjelek lesznek a sorok elején

Az első 3 sor sorkizárt lesz

( ) Nincs válasz

13. ábra A BCE elsős hallgatóival 2013-ban kitöltetett kérdőív szövegszerkesztési alapismeretekre rákérdező tesztkérdése (saját szerkesztés)

A helyes válasz adása nem is mutat szignifikáns összefüggést azzal, hogy hogyan ítélték meg az egyszerű szövegszerkesztési tudásukat a hallgatók. Ennél a tesztfeladatnál is azt látjuk, hogy inkább a nehezebb informatikai feladatcsoportok önbevallott tudásával mutat összefüggést a helyes válasz adása (hosszú dokumentumok kezelése, haladó függvények, adatok elemzése, prezentációkészítés, adatbázis-kezelés).

Az 5. kérdés kifejezetten a hosszú dokumentum szerkesztéséhez kapcsolódott (14. ábra)

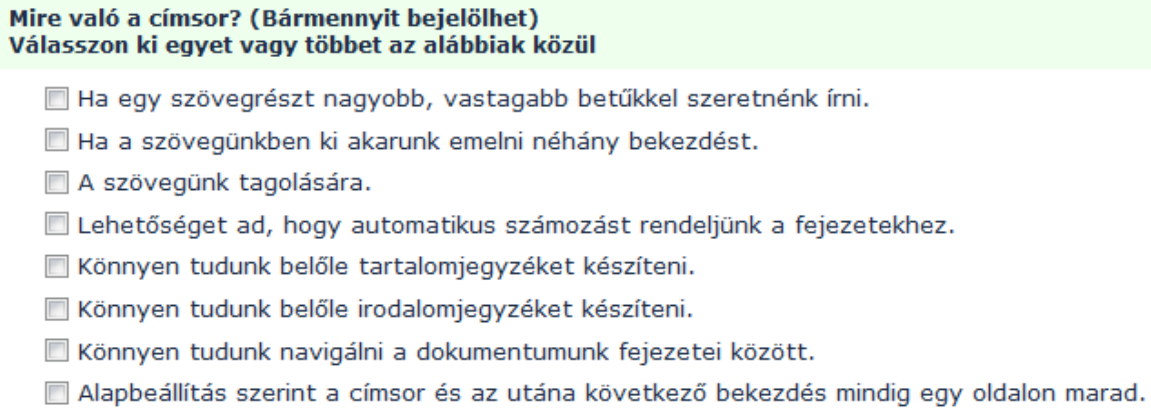

\section{4. ábra A BCE elsős hallgatóival 2013-ban kitöltetett kérdőív hosszú dokumentum szerkesztésre rákérdező tesztkérdése (saját szerkesztés)}

A válaszok közül a 3., 4., 5., 7. és 8. volt helyes. Az elemzésbe csak azokat a válaszadókat vontam bele, akik legalább egy választ megjelöltek. Nekik pontszámot adtam (1-8) aszerint, hogy hány kérdés helyességét találták el. (Mintha 8 igaz-hamis kérdés lett volna.) A 
lehetséges 8 pontból az átlag 3,94 lett. Miközben a megkérdezettek 54,73\% vallotta magát rutinosnak hosszú dokumentumok szerkesztésében 8 pontot mindössze 5 fó ért el és legalább 5 pontot is csak a 619 válaszadó 40,87\%-a (véletlen találgatással átlagosan 4 pontot lehetne elérni). Még furcsább, hogy ez az arány nem különbözik lényegesen az egyes kategóriákban.

16. táblázat Szövegszerkesztővel hosszú dokumentum készítése (címsorok, tartalomjegyzék, szakaszok, hasábok, lábjegyzet) önbevalláson alapuló ismerete és az erre rákérdező teszten elért eredmény összefüggése 2013-ban a BCE elsős hallgatóinál (saját szerkesztés)

\begin{tabular}{|c|c|c|c|c|c|c|c|c|c|c|}
\hline & \multicolumn{8}{|c|}{ TESZT_CIMSOR } & \multirow{2}{*}{ TOTAL } \\
\hline & & 1 & 2 & 3 & 4 & 5 & 6 & 7 & 8 & \\
\hline \multirow{2}{*}{ nem ismerem } & $\mathrm{db}$ & 0 & 3 & 3 & 6 & 2 & 4 & 0 & 0 & 18 \\
\hline & $\%$ & 0,00 & 16,67 & 16,67 & 33,33 & 11,11 & 22,22 & 0,00 & 0,00 & 1 \\
\hline \multirow{2}{*}{$\begin{array}{l}\text { ismereteim hiá- } \\
\text { nyosak, csak segít- } \\
\text { séggel tudok fel- } \\
\text { adatot megoldani }\end{array}$} & $\mathrm{db}$ & 2 & 23 & 51 & 87 & 51 & 30 & 14 & 1 & 259 \\
\hline & $\%$ & 0,77 & 8,88 & 19,69 & 33,59 & 19,69 & 11,58 & 5,41 & 0,39 & 1 \\
\hline \multirow{2}{*}{$\begin{array}{l}\text { segítség nélkül, ru- } \\
\text { tinosan tudok fel- } \\
\text { adatot megoldani }\end{array}$} & $\mathrm{db}$ & 3 & 37 & 45 & 103 & 67 & 56 & 24 & 4 & 339 \\
\hline & $\%$ & 0,88 & 10,91 & 13,27 & 30,38 & 19,76 & 16,52 & 7,08 & 1,18 & 1 \\
\hline
\end{tabular}

Az előző eredményeket erősíti meg ennek a kérdésnek a vizsgálata is. A szerzett pontszám a különböző táblázatkezelési tudáselemekkel és a prezentációkészítéssel mutat némi összefüggést. Úgy tűnik tehát, hogy a szövegszerkesztési képességeiket nem mérik fel hitelesen a hallgatók, de a szövegszerkesztési tesztek megoldása szignifikáns pozitív öszszefüggést mutat táblázatkezelési, prezentációs és bizonyos esetekben az adatbázis-kezelési képességek megítélésével, ami egy általános informatikai tudásszintet sejtet. Általában azok jobbak szövegszerkesztésböl is, akik a többi területen is jobbak. 
DOI: $10.14267 /$ phd.2014081

17. táblázat Táblázatkezelési és prezentációs feladatok önbevalláson alapuló ismerete és a hosszú dokumentum szerkesztésére rákérdező teszten elért eredmény összefüggése 2013-ban a BCE elsős hallgatóinál (saját szerkesztés)

\begin{tabular}{|l|r|r|}
\hline & $\begin{array}{c}\text { PEARSON } \\
\text { CORR. }\end{array}$ & SIG. \\
\hline Táblázatkezelővel táblázat készítése & 0,13 & 0,00 \\
\hline Táblázatkezelővel egyszerü képletek, függvények használata & 0,13 & 0,00 \\
\hline Táblázatkezelővel haladó függvények & 0,09 & 0,03 \\
\hline Táblázatkezelővel adatok elemzése & 0,12 & 0,00 \\
\hline Prezentációkészítés & 0,08 & 0,04 \\
\hline
\end{tabular}

Megvizsgáltam egy táblázatkezelésre vonatkozó kérdést is. Feltételezésem szerint ebben jobban meg tudták ítélni a hallgatók a saját tudásukat.

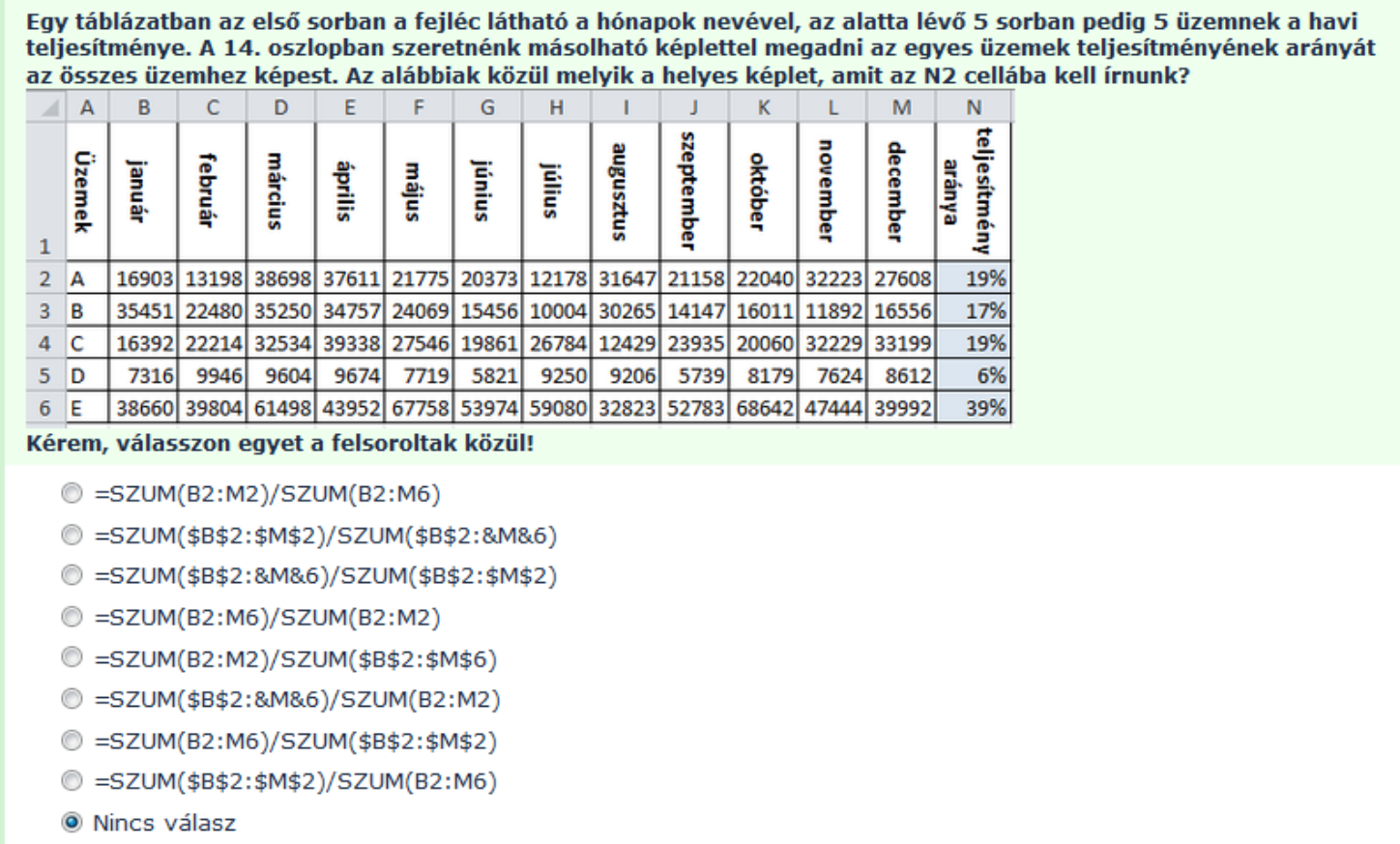

15. ábra A BCE elsős hallgatóival 2013-ban kitöltetett kérdőív abszolút-relatív hivatkozások kezelésére rákérdező tesztkérdése (saját szerkesztés)

A 10. kérdés az abszolút és relatív hivatkozás helyes használatára vonatkozott. (15. ábra) A helyes válasz az 5. volt. A 475 válaszadó közül 180 hallgató adott helyes választ, ez 37,89\%. Az önbevallás alapján 38,91\%-uk rutinos ezen a területen, de itt sincs szoros összefüggés. A logikusnak tünő táblázatkezelési tudáselemek mellett a kiadványkészítéssel, a prezentációkészítéssel és az adatbázis-kezeléssel is kimutatható az összefüggés. A legszorosabb az összefüggés azzal a területtel, amire rá is kérdezett a tesztkérdés, de itt is csak 0,20 a Pearson korreláció. 
DOI: $10.14267 /$ phd.2014081

18. táblázat Szövegszerkesztési, táblázatkezelési, prezentációkészítési és adatbázis-kezelési feladatok önbevalláson alapuló ismerete és az abszolút-relatív hivatkozás használatára rákérdező teszten elért eredmény összefüggése 2013-ban a BCE elsős hallgatóinál (saját szerkesztés)

\begin{tabular}{|l|r|r|}
\hline & $\begin{array}{c}\text { PEARSON } \\
\text { CORR. }\end{array}$ & SIG. \\
\hline Szövegszerkesztővel kiadvány (pl. plakát, meghívó) készítése & 0,13 & 0,01 \\
\hline Táblázatkezelővel táblázat készítése & 0,13 & 0,01 \\
\hline Táblázatkezelővel egyszerű képletek, függvények használata & 0,21 & 0,00 \\
\hline Táblázatkezelővel haladó függvények & 0,20 & 0,00 \\
\hline Táblázatkezelővel adatok elemzése & 0,20 & 0,00 \\
\hline Prezentációkészítés & 0,17 & 0,00 \\
\hline Adatbázis-kezelés & 0,16 & 0,00 \\
\hline
\end{tabular}

19. táblázat Táblázatkezelő egyszerű használatának önbevalláson alapuló képessége és az erre rákérdező teszten elért eredmény összefüggése 2013-ban a BCE elsős hallgatóinál (saját szerkesztés)

\begin{tabular}{|c|c|c|c|c|}
\hline & \multicolumn{2}{|c|}{ TESZT_HIVATKOZAS } & \multirow[b]{2}{*}{ TOTAL } \\
\hline & & $\mathbf{0}$ & 1 & \\
\hline \multirow[b]{2}{*}{ nem ismerem } & $\mathrm{db}$ & 40 & 20 & 60 \\
\hline & $\%$ & 66,7 & 33,3 & 100 \\
\hline \multirow{2}{*}{$\begin{array}{l}\text { ismereteim hiányosak, csak segít- } \\
\text { séggel tudok feladatot megoldani }\end{array}$} & $\mathrm{db}$ & 151 & 56 & 207 \\
\hline & $\%$ & 72,9 & 27,1 & 100 \\
\hline \multirow{2}{*}{$\begin{array}{l}\text { segítség nélkül, rutinosan tudok } \\
\text { feladatot megoldani }\end{array}$} & $\mathrm{db}$ & 103 & 103 & 206 \\
\hline & $\%$ & 50 & 50 & 100 \\
\hline
\end{tabular}

A kereszttáblából is leolvasható, hogy a magukat rutinosnak valló hallgatóknak is csak az 50\%-a tudta megadni a helyes választ (19. táblázat). Az is érdekes viszont, hogy akik azt állították, hogy egyáltalán nem értenek a területhez, azoknak is a 33,3\%-a helyesen válaszolt. 
Egy program beolvas a felhasználótól egy egész számot a "szam" nevũ változóba. Az alábbiak közül melyik a helyes programrészlet, ha azt szeretnénk elérni, hogy páros szám esetén vízszintesen, páratlan szám esetén függőleges irányban írja be a számokat az Excel 1-tôl a megadott számig a cellákba A1-tôl kezdve?

Kérem, válasszon egyet a felsoroltak közül!

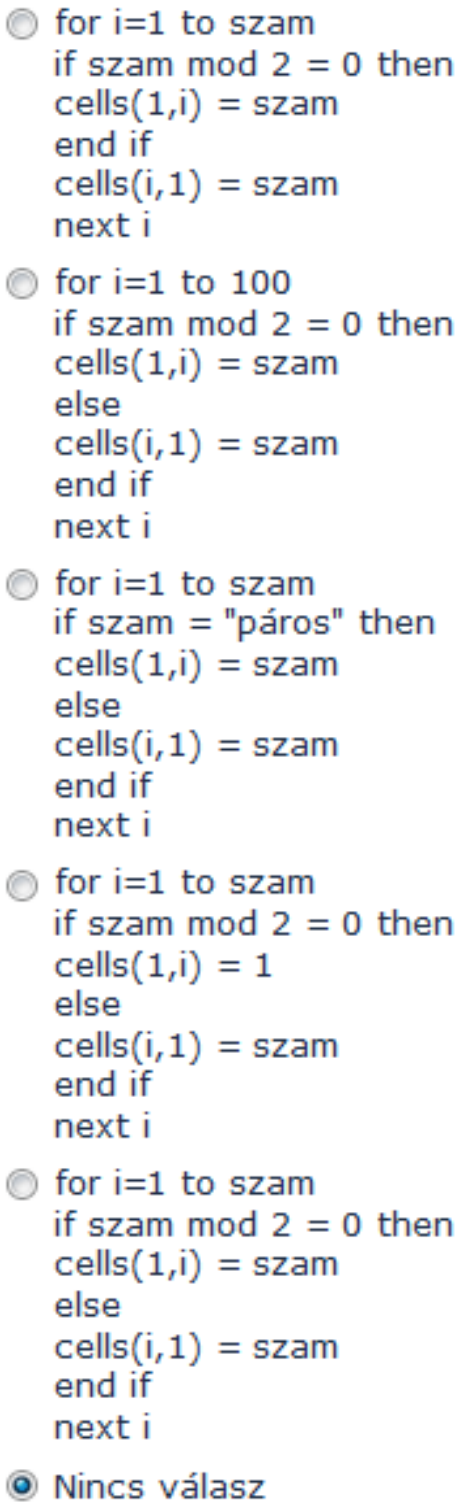

16. ábra A BCE elsős hallgatóival 2013-ban kitöltetett kérdőív programozási ismeretekre rákérdező tesztkérdése (saját szerkesztés)

Ennek az oka az is lehet, hogy a tudáselemnél felsorolt többi részletet nem ismerték, de konkrétan a hivatkozásokat igen. (Itt voltak még felsorolva statisztikai függvények, AUTOSZUM, HA, DARABTELI.) Helyes volt a feltételezésem, hogy a táblázatkezelés területén szorosabb volt az összefüggés az önbevallott képesség és a teszteredmény között. 
Az utolsó kérdés egy programozási feladat volt, amit a konkrét programnyelv ismerete nélkül is meg lehetett oldani (16. ábra). Az utolsó válasz volt a helyes, ezt a válaszolók mindössze 17,6\%-a találta el (61 fö a 347-ből). A kérdőív kitöltőinek közel fele (329 fö) meg sem kísérelte a válaszadást.

A várhatónak megfelelően szignifikáns az összefüggés a programozás tudás megítélése és a kérdésre adott válasz helyessége között. A Pearson korreláció 0,21. A kereszttáblából az is kiolvasható, hogy a magukat rutinos programozónak valló hallgatók 70\%-a válaszolt helyesen, ez egészen pontosan 7 főt jelent a 10-ből. A hiányos ismeretekkel rendelkezőknek viszont csak 22,8\%-a adott helyes választ (20. táblázat).

20. táblázat Programozás önbevalláson alapuló ismerete és az erre rákérdező teszten elért eredmény összefüggése 2013-ban a BCE elsős hallgatóinál (saját szerkesztés)

\begin{tabular}{|c|c|c|c|c|}
\hline & \multicolumn{2}{|c|}{ TESZT PROGRAMOZÁS } & \multirow[b]{2}{*}{ TOTAL } \\
\hline & & $\mathbf{0}$ & 1 & \\
\hline \multirow[b]{2}{*}{ nem ismerem } & $\mathrm{db}$ & 237 & 41 & 278 \\
\hline & $\%$ & 85 & 15 & 1 \\
\hline \multirow{2}{*}{$\begin{array}{l}\text { ismereteim hiányosak, csak segít- } \\
\text { séggel tudok feladatot megoldani }\end{array}$} & $\mathrm{db}$ & 44 & 13 & 57 \\
\hline & $\%$ & 77 & 23 & 1 \\
\hline \multirow{2}{*}{$\begin{array}{l}\text { segítség nélkül, rutinosan tudok } \\
\text { feladatot megoldani }\end{array}$} & $\mathrm{db}$ & 3 & 7 & 10 \\
\hline & $\%$ & 30 & 70 & 1 \\
\hline
\end{tabular}

\section{V.2.5. A bejövő hallgatók informatikai előismereteit kutató kérdőíves fel- mérések eredményeinek összefoglalása}

Ennek a kutatássorozatnak a fó célja az volt, hogy tisztábban lássuk, hogy milyen bejövő ismeretekre támaszkodhatunk, illetve hogy ennek változásában milyen tendenciák figyelhetők meg. A 2005-06-os tanévben végzett vizsgálat eltért az elmúlt két tanév vizsgálataitól, de bizonyos kérdések lehetőséget adtak az összehasonlításra és látványosan kirajzolódott a 7 év alatt megmutatkozó fejlődés. Az utóbbi két kutatásból pedig az vált egyértelmüvé, hogy nem elég a jogszabályok ismerete ahhoz, hogy meg tudjuk ítélni az egyetemet kezdő hallgatók informatikai kompetenciáit. Az utolsó kutatás megkísérelt képet adni arról is, hogy az önbevallás mennyiben lehet összhangban a valódi kompetenciákkal. Az eredmények korlátozottan alkalmasak a következtetések levonására, de indokoltnak tünik a bejövő hallgatók mérése az egyszerü megkérdezés helyett, ez viszont erőforrás 
problémákat vethet fel, hiszen egy ellenörzött mérés lebonyolítása nehezebb, mint egy kérdőív kitöltetése.

A különböző részminták elemzése azt mutatta, hogy a különböző felsőoktatási intézményekben és különböző szakokon tanuló hallgatók jellemzőiben minimális a különbség. A nappalis és levelezős hallgatók összehasonlítása a várt eredményt hozta, hiszen a levelezős hallgatók között nagyobb arányban vannak olyanok, akik korábban jártak középiskolába, illetve akik munkájuk során sajátítottak el különböző informatikai képességeket.

A nappali tagozatos hallgatók az internethasználatban, a szövegszerkesztővel egyszerü szöveg szerkesztésében és a prezentációkészítésben ítélik legjobbnak a tudásukat. Az átlagosnál valamivel jobbra értékelik még a kompetenciájukat szövegszerkesztővel hosszú dokumentum és kiadvány szerkesztésébe és táblázatkezelővel táblázat és egyszerü képletek készítésében. A programozás és a táblázatkezelő haladó használata kapta a legkisebb értékeket. Az érettségi követelmények között szereplö területek közül az átlagosnál gyengébbre értékelik saját tudásukat adatok elemzésében (diagramok, feltételes formázás, autoszürő, kimutatás), webszerkesztésben és adatbázis-kezelésben.

Az összefüggéseket vizsgálva megállapítható, hogy a legtöbb területen a legnagyobb magyarázóerővel az bír, hogy tanították-e az adott képességeket a középiskolában. Ez alól csak az internethasználat a kivétel. Az összefüggés viszont általában nem túl magas, ami egyfelől azt jelenti, hogy nem mindent tudnak, amit tanítottak nekik, másfelöl azt, hogy máshonnan is szereznek tudást. A legmagasabb az összefüggés az adatbázis-kezelésnél, az adatelemzésnél és az egyszerü képletek használatánál.

A bizonyítványokkal kapcsolatban azt állapítottam meg a számítások alapján, hogy az informatika érettségi, illetve az ECDL bizonyítványok megléte vagy hiánya nem szolgáltat elegendő információt a hallgatók informatikai kompetenciáiról.

A 2013-as kutatás alapján megállapítható a technológia fejlődésének megjelenése a diákok számítógép-használatában, nyílt kérdésre felsoroltak különböző nyílt forráskódú és felhő alkalmazást is, bár az említésszámok elég alacsonyak.

Mivel az eredmények azt mutatják, hogy a hallgatók tudása nem csak az iskolából származik, rákérdeztem az egyéb forrásokra is. Itt magas arányban szerepelt a válaszok között, hogy barátoktól, családtól illetve hogy autodidakta módon is tanultak. A levelezösöknél a várhatónak megfelelöen többen jelölték meg a munkahelyet is. 
A hallgatók több mint 90\% napi több órát tölt a számítógép elött, a levelezősök többet, mint a nappalisok, vélhetőleg szintén a munkából kifolyólag.

\section{V.3. Interjúk: szaktanszéki és módszertani kollégákkal}

\section{V.3.1. Tanszéki interjúk az Általános Vállalkozási Főiskolán}

Az ÁVF-en a kötelező informatikaoktatás keretében két féléven keresztül (szakonként eltérően 1. és 2 vagy 2. és 3. félév) heti 2 gyakorlati órában folyik az informatikaoktatás. Előadás mindkét félévben csak $2 \times 2$ óra van. A tananyag szövegszerkesztést, táblázatkezelést, adatbázis-kezelést és Excel makrókat tartalmaz.

A tanszékekkel folytatott beszélgetések vegyes képet mutattak. Egymásnak ellentmondó elvárások és meglepő módon egymásnak ellentmondó tapasztalatok is felszínre kerültek, ugyanakkor a 11 beszélgetés során ( 9 tanszék, Idegen nyelvi lektorátus, Záróvizsga központ) voltak visszatérő elemek is. A felmerülő témaköröket utólag 3 csoportra bontottam:

- hallgatói teljesítmény

- informatika tárgyak tartalma

- oktatói elvárások

Az első témakörben tapasztaltam leginkább ellentmondásokat. Volt több kolléga, aki dicsérte a főiskola hallgatóit, elegendőnek, sőt jónak találta az informatikai ismereteiket. Sokan azonban arról számoltak be, hogy még az alapok is nehézséget jelentenek a többségnek. Sorra derültek ki olyan problémák, amit a kötelező informatika tárgyak keretében megtanítunk, számon kérünk, majd félévekkel később a hallgatók egyáltalán nem tudják öket. Egyik sztenderd visszatérö probléma a szövegszerkesztésben a dolgozatok szerkesztése: tartalomjegyzék, oldalszámozás, hogy az egyéb szépségeket már ne is említsük. A 11 beszélgetésből 8-ban került szóba a szakdolgozatok siralmas szerkesztése.

Az informatika egyik fontos felhasználási területe az információk keresése az Internet segítségével. Itt is több volt a negatív tapasztalat, mint a pozitív.

Prezentációkészítéssel kapcsolatban azt tapasztalták a kollégák, hogy az általában technikai értelemben megy, vagy már hozzák a középiskolából ezt a tudást, vagy a föiskolai tanulmányok során belejönnek, hiszen több tantárgyból is szükség van előadások készítésére. Ezzel kapcsolatban inkább olyan problémák merültek fel, melyek nem informatikai jellegűek. Elgondolkodtató, hogy ezeket mennyire lehet az informatikaoktatás részévé tenni. Több beszélgetés során (5) elhangzott, hogy a hiányosságok egy része nem is a 
tudás hiányából, inkább az igényesség hiányából fakad. Igényességet tanítani szép pedagógiai kihívás, leginkább az elvárások felől lehet szerintem megközelíteni.

Az okok között felmerült, hogy időben távol esik egymástól az informatikai ismereteknek a tanítása és a használata, a hallgatók fejében elszigetelten jelennek meg a különböző tantárgyi tartalmak, nem tudják ezeket összekapcsolni. E probléma áthidalása két úton történhet. Egyrészt az informatikaoktatás során olyan példákat kell tudnunk mutatni a hallgatóknak, melyek kapcsolódnak a többi tárgyukhoz. Ez azonban gyakran olyan problémát jelent, hogy az első évben még hiányzik a szaktudás ezeknek a példáknak a megértéséhez. A másik út, hogy a szaktárgyak keretében is kell az informatikával foglalkozni. Ez viszont óraszámbeli problémákat vet fel. Azt is meg kell említenem, hogy több tanszék tantárgykínálatában jelenleg is szerepel olyan kurzus, amely géptermi órákat is tartalmaz. Gyakran azonban ezeket az órákat nem tudják hatékonyan a speciális ismeretek átadására használni, mert az alapokat kell újra átvenniük a hallgatókkal.

A tartalmi felvetések között markánsan megjelent a szakmai szoftverek beemelésének igénye. Szintén kérdést vethet fel, hogy ez az alap informatika tárgyak keretében, vagy inkább szakirányokon a megfelelő szaktárgyak keretében valósulhat-e meg. Több tanszéken került elő az SPSS program használata. Felmerült egyes vállalatirányítási szoftverek bemutatásának igénye. Ez egyébként választható tantárgyi keretben akkor még szerepelt a tárgyak között. A legtöbbször az Excel stabil használatát emelték ki a kollégák, mint szükséges ismeret ( 8 beszélgetés), 3 tanszéken az Access adatbázis-kezelőt is fontosnak tartották. Mindkettő szerves részét képezi jelenleg is az alap informatika tárgyak tananyagának a föiskolán.

Sokan emelték ki a vizualizációt is: akár speciális szoftver tanításával (anyagi problémákat vet fel), akár a táblázatkezelő diagramjainak mélyebb ismeretével, a Word szövegszerkesztő folyamatábra rajzolójának megismerésével.

A prezentációkészítés ugyan általában megy a hallgatóknak annak ellenére, hogy az alap informatika gyakorlatoknak nem volt része ennek tanítása, de lennének olyan plusz eszközök ezen belül is, amit jó lenne, ha a hallgatók jobban ismernének.

3 tanszéken az is szóba került, hogy alapismeretek szintjén is komoly hiányosságok vannak. Minimális hardver és operációs rendszer ismeretre is szükség volna. Jó lenne, ha egy problémára a hallgatók önállóan tudnának megoldást keresni, egy új szoftvert (akár az 
internetről letölthető ingyenes programot) tudnának telepíteni, help alapján megtanulni használni.

3 tanszéken került szóba, hogy jelenleg programozási ismeretek is szerepelnek a tananyagban. Mindhárom tanszéken az volt a markáns vélemény, hogy erre az ÁVF hallgatóinak nincs szüksége, föleg annak fényében, hogy még az alapismeretek is kihívást jelentenek sokuk számára.

A gazdálkodás és menedzsment alapszakon az első félévben egyáltalán nincs informatika tantárgy. Erre áthidaló megoldásként vagy tantárgycsere (ez komoly nehézségekbe ütközne), vagy valami szintre hozó kurzus ötlete merült fel.

A harmadik témakör nem az informatika oktatással kapcsolatos, hanem a föiskolán müködő informatikai szolgáltatásokkal és a kollégák informatikai problémáival. A főiskolán 2011 szeptembertől müködő e-learning rendszer bevezetésével kapcsolatban igényelnének a tanárok több támogatást. A legtöbb oktató üdvözölte azt a lehetőséget, hogy úgynevezett „Dolgozói fogadóóra” keretében fordulhatnak az informatika tanárokhoz felhasználói problémákkal. (2012-13-as tanévben néhányan már éltek is ezzel a lehetőséggel.)

Több tanszéken is felmerült, hogy jó lenne újdonságokat megtanulni, ami könyvekből és helpből lehetetlennek tünő feladat, aminek egyik oka az időhiány, de többen említették a könyvek és helpek nehézkességét is. Legtöbbször a prezi.com megtanulása merült fel igényként.

A legtöbb tanszéken üdvözölték azt is, hogy egy kis bepillantást nyertek abba, hogy mit tanítunk informatikából.

\section{V.3.2. Tanszéki interjúk a Budapesti Corvinus Egyetemen}

A 2013-14-es tanév folyamán A BCE Számítástudományi Tanszék tanszékvezetőjével, Fehér Péterrel felkerestük az egyetemen futó szakok szakfelelőseit azzal a kéréssel, hogy segítsenek nekünk az alapozó informatika tárgyak megújításában azzal, hogy elmondják, az ő véleményük szerint milyen informatikai alapképzésre van szüksége a hallgatóiknak. Teljes volt az egyetértés abban, hogy a táblázatkezelő rutinszerü használatát várják el a hallgatóiktól. A gazdaságelemzés, az alkalmazott közgazdaságtan, pénzügy és számvitel és az emberi erőforrások szakon az algoritmizálást, illetve valamilyen szintü Excel prog- 
ramozást is elvártak. A gazdaságelemzés szakon külön hangsúlyozták az informatika fontosságát, súlyának esetleges növelését a képzésben. Mindenképpen ragaszkodtak az optimalizáló eszköz (Solver) megtanításához. Korábban ezen a szakon Excel programozás helyett a Maple program szerepelt a kötelező tárgyban, de ehhez a továbbiakban nem ragaszkodnak. Az emberi erőforrások szak oktatói fontosnak tartották kihangsúlyozni az adatkezelés alapvető voltát, illetve a gondolkodni tanulást. Azt, hogy a táblázatkezelő használata során elsajátított képességeket aztán más alkalmazások használata során is fel tudják használni a hallgatók. A gazdálkodási és menedzsment szak oktatói szintén a táblázatkezelést találták elsősorban fontosnak, azon belül az alap eszközökön kívül a makrók használatának elsajátítását is szívesen látnák. Felmerült még különböző csoportmunkát elősegítő alkalmazások igénye is.

\section{V.3.3. Az interjúk tanulságainak összefoglalása}

Mindkét intézményben folytatott beszélgetésekből a táblázatkezelés, adatkezelés dominanciája rajzolódott ki. Arról, hogy a hallgatók a munkahelyükön pontosan milyen kompetenciákkal boldogulnának jól, sehol nem rendelkeztek alátámasztott információval, inkább csak elképzelésekkel, következtetésekkel.

Alapvető különbség volt a főiskolán és az egyetemen folytatott beszélgetésekben, hogy a főiskolán szinte minden tanszéken szóba került a szövegszerkesztés is, azon belül első sorban a hosszú dokumentumok szerkesztése, mint kívánatos kompetencia, amivel a hallgatók egy része tapasztalatuk szerint nem rendelkezik. Az egyetemen ez nem merült fel. Másik irányú eltérés, hogy az Excel makrókat illetve az algoritmizálást a főiskolán feleslegesnek ítélték, míg az egyetemen elvárják.

Mindkét intézményben volt olyan vélemény, hogy az informatikaoktatás keretében az alapokat kell jól lefektetni, hogy aztán azokra a szaktárgyak keretében a szaktanszékek oktatói tudjanak építkezni.

\section{V.4. Alumni kutatások eredménye}

\section{V.4.1. Kísérleti kutatás az Általános Vállalkozási Főiskola végzettjei köré- ben}

Az Általános Vállalkozási Főiskola végzettjei körében végeztem online kitölthető elektronikus önkitöltős kérdőíves vizsgálatot 2012 februárjában arra vonatkozóan, hogy a 
munkájuk során milyen kapcsolatba kerülnek az informatikával. Az itt bemutatott felmérés kísérleti jellegü. Az eredményekből általános érvényü következtetéseket nem lehet levonni, de segíti a további kutatások előkészítését.

Az Általános Vállalkozási Főiskola Karrier Irodájával együttműködve az alumni adatbázison keresztül juttattuk el a kérdőívet 3823 végzett hallgatónak. Közülük 189 fö töltötte ki teljesen vagy részlegesen a kérdőívet.

A kísérleti kutatás segítségével az alábbi kérdésekre igyekeztem választ keresni:

1. Van-e kimutatható eltérés az egyes szakokon végzett hallgatók munkahelyi informatika használatában?

2. Az oktatás tartalmának időbeli változása kihatással van-e a munkahelyi alkalmazásra?

3. Az ECDL alapmodulok tananyaga milyen mértékben illeszkedik a munkahelyi követelményekhez?

A válaszadókat szakjuk alapján hat csoportba soroltam :

1. Gazdálkodási és menedzsment alapszak, Vállalkozásszervező főiskolai szak

2. Nemzetközi tanulmányok alapszak, Nemzetközi kapcsolatok főiskolai szak

3. Közszolgálati alapszak, Non-profit gazdálkodási főiskolai szak

4. Üzleti kommunikáció főiskolai szak

5. Felsőfokú szakképzés: Reklámszervező szakmenedzser, Üzleti szakmenedzser

6. Vállalkozásfejlesztés mester szak

A A válaszadók 43,9\%-a nagyvállalatnál, 22,2\% közép míg 13,1\% és 12,1\% kis- és mikrovállalatnál dolgozik. $70,7 \%$ beosztott és mindössze 3,5\% felsővezető.

Arra a kérdésre, hogy volt-e informatikai ismeretekre, készségekre vonatkozó része a munkahelyi felvételi eljárásnak 176-an válaszoltak összesen, valamivel több mint fele igennel (54,5\%). Ezek közül legtöbbjüknél az állásinterjú során kérdeztek rá (64fö) tudásukra, 25 fönek pedig gyakorlati feladatokat is meg kellett oldania. Volt, akinek írásbeli tesztet kellett kitöltenie (7 fö). Az informatikai követelmények között a táblázatkezelés és a szövegszerkesztés szerepelt a legtöbbször. Magas említésszámmal szerepelt még az internethasználat (61) és a prezentációkészítés (56). Adatbázis-kezelési ismereteket a válaszadók egyharmadától vártak el. 
21. táblázat azt mutatja, hogy a minta milyen mértékben illeszkedik szakok alapján az alapsokasághoz. A táblázatból látható, hogy a kitöltők között nagyobb arányban szerepeltek az üzleti kommunikáció szakon végzett hallgatók és az átlagos kitöltési aránynál lényegesen kisebb arányban szerepeltek a felsőfokú szakképzésben végzett hallgatók.

A válaszadók 43,9\%-a nagyvállalatnál, 22,2\% közép míg 13,1\% és $12,1 \%$ kis- és mikrovállalatnál dolgozik. $70,7 \%$ beosztott és mindössze 3,5\% felsővezető.

Arra a kérdésre, hogy volt-e informatikai ismeretekre, készségekre vonatkozó része a munkahelyi felvételi eljárásnak 176-an válaszoltak összesen, valamivel több mint fele igennel (54,5\%). Ezek közül legtöbbjüknél az állásinterjú során kérdeztek rá (64 fö) tudásukra, 25 főnek pedig gyakorlati feladatokat is meg kellett oldania. Volt, akinek írásbeli tesztet kellett kitöltenie (7 fö). Az informatikai követelmények között a táblázatkezelés és a szövegszerkesztés szerepelt a legtöbbször. Magas említésszámmal szerepelt még az internethasználat (61) és a prezentációkészítés (56). Adatbázis-kezelési ismereteket a válaszadók egyharmadától vártak el.

21. táblázat Kérdőív kitöltési arány szakcsoportonként és összesen, ÁVF alumni 2012 (saját szerkesztés)

\begin{tabular}{|l|c|c|c|}
\hline \multicolumn{1}{|c|}{ SzAKCSOPORTOK } & N & n & $\begin{array}{c}\text { KITÖLTÉSI } \\
\text { ARÁNY }\end{array}$ \\
\hline $\begin{array}{l}\text { 1. Gazdálkodási és menedzsment alapszak, } \\
\text { Vállalkozásszervezö }\end{array}$ & 3073 & 130 & $4,23 \%$ \\
\hline $\begin{array}{l}\text { 2. Nemzetközi tanulmányok alapszak, Nemzetközi } \\
\text { kapcsolatok }\end{array}$ & 679 & 19 & $2,80 \%$ \\
\hline 3. Közszolgálati alapszak, Non-profit gazdálkodási & 266 & 14 & $5,26 \%$ \\
\hline $\begin{array}{l}\text { 4. Üzleti kommunikáció } \\
\text { 5. Felsőfokú szakképzés: Reklámszervezö és Üzleti } \\
\text { szakmenedzser }\end{array}$ & 217 & 18 & $8,29 \%$ \\
\hline 6. Mesterképzés: Vállalkozásfejlesztés & 6 & $1,15 \%$ \\
\hline Végösszeg & 29 & 2 & $6,90 \%$ \\
\hline
\end{tabular}




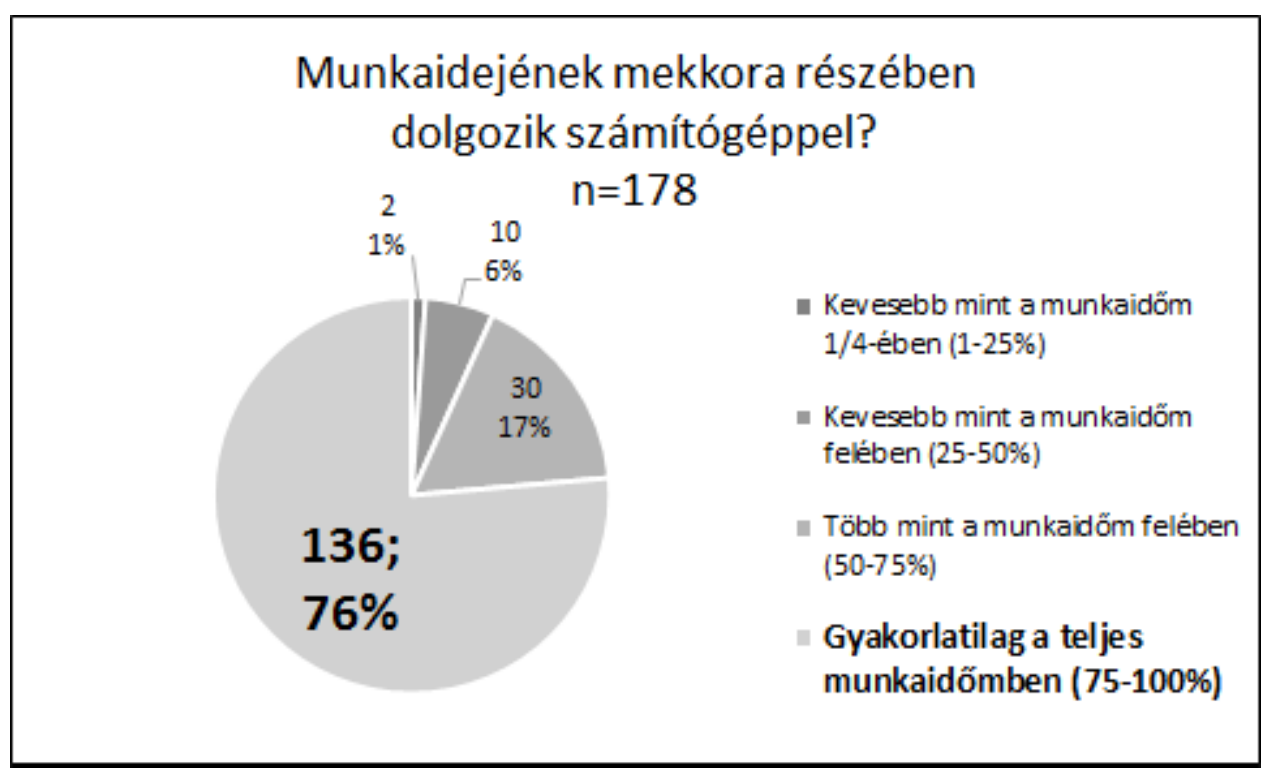

17. ábra Számítógép előtt töltött munkaidő az ÁVF alumni kutatás kitöltőinél (2012) (Saját szerkesztés)

A válaszadók több mint háromnegyede idejének több mint háromnegyedét a számítógép előtt tölti. (17. ábra) Ez az adat alátámasztja azt is, hogy valóban fontos lehet ezzel a területtel mélyrehatóbban foglalkozni, hiszen mindössze egyetlen ember jelezte, hogy eredeti végzettsége informatikus, és a munkája is ehhez kapcsolódik. Mindenki más gazdasági jellegü végzettségével végez olyan munkát, amihez a jelek szerint rengeteget kell a számítógépet használnia.

Az számítógépes munkát részleteiben is pontosítani kívántuk. A 22. táblázatban látható, hogy az általunk felsorolt feladatok közül melyeket jelölték meg legtöbben. A leggyakoribb feladat a (belső és a kifelé irányuló) kommunikáció. Figyelemre méltó, hogy a táblázatkezelők használata megelőzi a szövegszerkesztési feladatokat. Kifejezetten informatikusi feladatok a megkérdezettek kevesebb mint 10\%-ánál fordulnak elő (17., 18.), ezek a céges adatbázis létrehozása $(9,1 \%)$ illetve a webszerkesztés $(7,1 \%)$. 
DOI: $10.14267 /$ phd.2014081

22. táblázat Számítógépes munkavégzés jellege, ÁVF alumni 2012 (saját szerkesztés)

\begin{tabular}{|l|c|}
\hline \multicolumn{1}{|c|}{$\begin{array}{c}\text { MILYEN JELLEGŰ FELADATOKAT VÉGEZ, MILYEN PROGRAMOKAT } \\
\text { HASZNÁL A MUNKÁJA SORÁN? }\end{array}$} & $\begin{array}{c}\text { IGENEK } \\
\text { ARÁNYA }\end{array}$ \\
\hline 1.Cégen belüli kommunikáció & $78,8 \%$ \\
\hline 2. Táblázatkezelővel adatlisták készítése, kezelése & $74,7 \%$ \\
\hline 3. Szövegszerkesztővel hivatalos levelek írása & $67,7 \%$ \\
\hline 4. Kommunikáció az interneten & $66,7 \%$ \\
\hline 5. Táblázatkezelővel kimutatások, elemzések, összesítések készítése & $63,6 \%$ \\
\hline 6. Szöveges feljegyzések készítése & $55,6 \%$ \\
\hline 7. Táblázatkezelővel modellezések, számítások végzése & $33,3 \%$ \\
\hline 8. Cégirányítási szoftver használata & $31,8 \%$ \\
\hline 9. Cégnyilvántartási szoftverek használata & $27,8 \%$ \\
\hline 10. Céges adatbázis kezelése adatbázis-kezelővel & $26,3 \%$ \\
\hline $\begin{array}{l}\text { 11. Szövegszerkesztővel rövid kiadványok (pl. meghívó, plakát, } \\
\text { programfüzet) készítése }\end{array}$ & $23,7 \%$ \\
\hline 12. Könyvelés könyvelő programmal & $22,2 \%$ \\
\hline 13. Képszerkesztés & $21,2 \%$ \\
\hline $\begin{array}{l}\text { 14. Szövegszerkesztővel hosszú kiadványok (pl. tanulmányok, } \\
\text { konferenciakötetek) készítése }\end{array}$ & $12,1 \%$ \\
\hline 15. Döntéstámogató szoftverek használata & $11,6 \%$ \\
\hline 16. Számlázás táblázatkezelővel & $11,6 \%$ \\
\hline 17. Céges adatbázis létrehozása, karbantartása adatbázis-kezelővel & $9,1 \%$ \\
\hline 18. Webszerkesztés & $7,1 \%$ \\
\hline 19. Egyéb & $2,5 \%$ \\
\hline
\end{tabular}

A munkahelyi felvételiben szereplő részterületek és a munkahelyen leginkább használt területek is alátámasztják, hogy a szövegszerkesztés és a táblázatkezelés területét érdemes mélyebben megvizsgálni. A kérdőívben két kérdést tettünk fel a szövegszerkesztési és táblázatkezelési feladatokkal kapcsolatban: „Jelölje minden sorban, hogy SZÖVEGSZERKESZTŐ/ TÁBLÁZATKEZELŐ használatakor az adott funkciót milyen gyakran és milyen stabilan használja! A válaszoknál ne csak a munkahelyére gondoljon, hanem minden alkalomra, amikor szövegszerkesztőt használ!"

A hiányos kitöltések miatt csak a gyakori használatra vonatkozó válaszok elemzésére nyílt lehetőségem. Itt 5 fokozatú skálán kellett válaszolni: soha; már egyszer kellett; rit- 
kán; gyakran; naponta. A statisztikai eszközök megfelelő használata érdekében az 5 fokozatú skálát minden esetben 3 fokozatúra redukáltam, mert az eredeti skála kétmóduszú gyakorisági eloszlásokat mutatott. Az átalakítás után a gyakori használatra vonatkozó kérdéseknél a 3 választípus: 0 - soha, 1 - már egyszer illetve ritkán, 2 - gyakran illetve naponta. A kérdések kódolásánál E-vel jelöltem azokat a funkciókat, melyek az ECDL alapmoduljainak vizsgakövetelményei között is szerepelnek és P-vel az ezen túlmutató eszközöket.

Sikerült mindkét alkalmazás területén elkülönítenem olyan feladatcsoportokat, amelyek a válaszok alapján közelebb estek egymáshoz. Ezt sokdimenziós skálázás módszerével vizsgáltam (Multidmensional Scaling, magyar fordításban sokdimenziós illetve többdimenziós skálázás néven egyaránt megtalálható a szakirodalomban).A modell lényege, hogy a sokdimenziós térből matematikai leképezés útján egy redukált dimenziószámú térbe helyezzük el a vizsgált változókat. Az algoritmus célja, hogy a redukált térben a változók közötti távolságok a lehető leginkább megfeleljenek az eredeti térben megfigyelhető távolságoknak. Általában minél több dimenziós végeredmény jobb illeszkedési mutatóval rendelkezik, de a 2 dimenziós végeredmény sokkal könnyebben átlátható és könnyebben interpretálható. [Füstös at. al., 2004] A modellt és az ábrákat az SPSS programcsomag PASW Statistics 18 verziójával készítettem.

Az illeszkedést mérő Stress mutatók alapján a kétdimenziós modell jósága mindkét feladatcsoportnál közepes(szövegszerkesztésnél 0,13, táblázatkezelésnél 0,11) és a térképen kialakuló elhelyezkedés mindkét esetben jól interpellálható (18. ábra és 19. ábra).

Az ábrákon látható kódok magyarázata az 5. mellékletben található. 


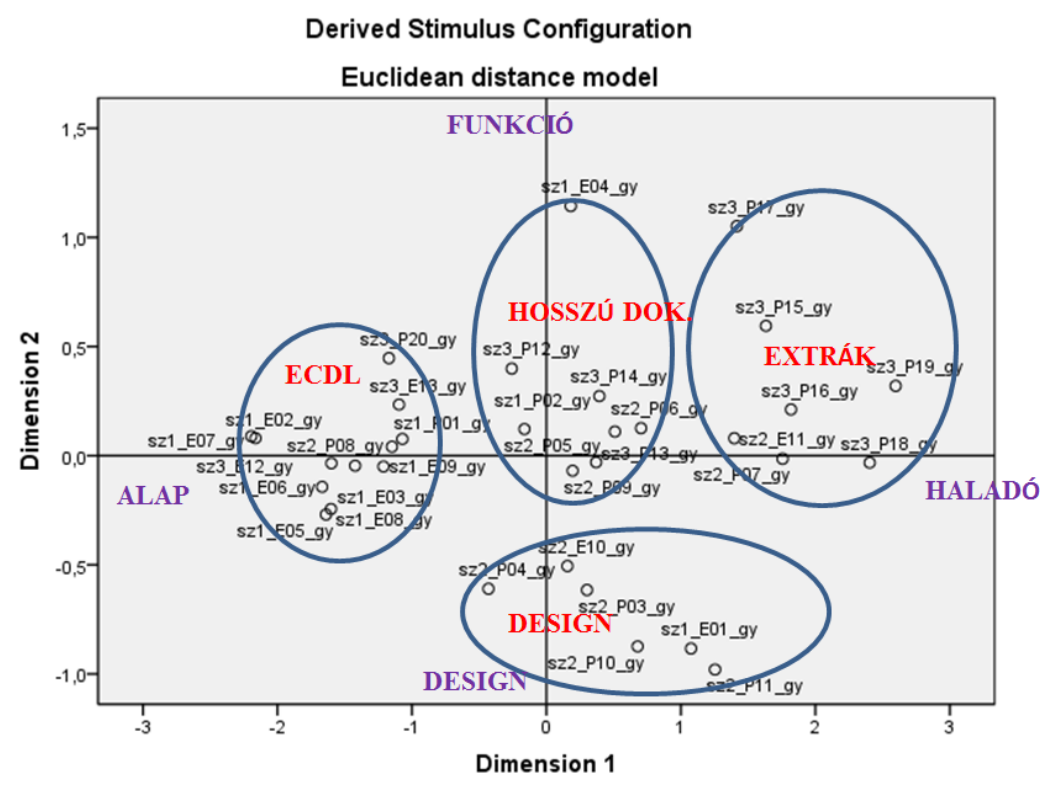

18. ábra A sokdimenziós skálázás eredménye a szövegszerkesztő használatának gyakoriságára 2 dimenzióban (saját szerkesztés)

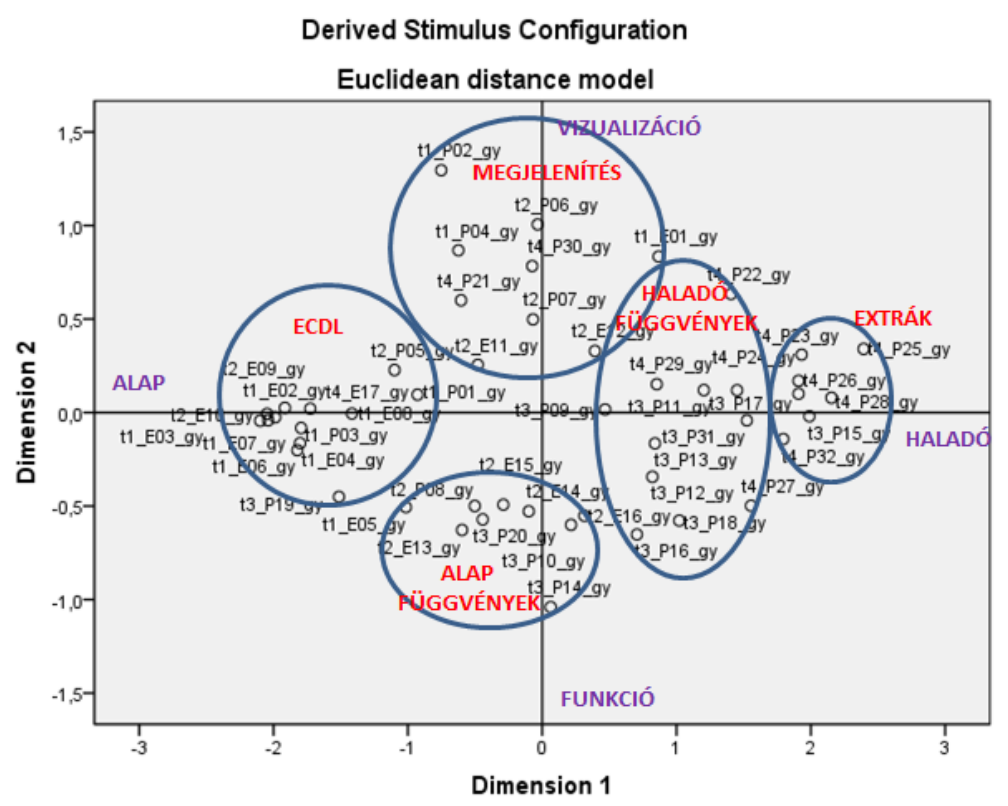

19. ábra A sokdimenziós skálázás eredménye a táblázatkezelő használatának gyakoriságára 2 dimenzióban (saját szerkesztés)

A szövegszerkesztési feladatok térképén az E04 (elválasztás) és a P17 (jelszavas védelem) kicsit leszakad a csoportjaiktól, de tartalmilag jól illeszkednek a kialakított csoportokba, külön kategóriát nem lett volna értelme rájuk létrehozni. Az elválasztás a távolságmátrix alapján olyan funkciókhoz esik legközelebb, amelyek a térképen távolabb helyezkednek el, pl. a Design kategóriában lévő stíluskészletek (E10), vagy az ECDL kategóriában lévő többszintű felsorolás (P01), de a Hosszú dokumentum kategóriában lévő címsor, tartalomjegyzék és szakaszok is közel esnek hozzá (P05, P06, P12). A táblázatkezelési feladatok térképén nem szerepelnek nagyon kilógó pontok. 
A kialakított változócsoportokat összevontam egy-egy változóba egyszerü súlyozatlan átlagot használva. A 23. táblázatban az összevont változók adatai láthatók. A 20. ábra az összevont változók gyakorisági eloszlásait mutatja.

23. táblázat Az összevont változók statisztikai adatai, ÁVF alumni 2012 (saját szerkesztés)

\begin{tabular}{|c|c|c|c|}
\hline & N & ÁTLAG & SzóRÁs \\
\hline SzöVEGSzERKESzTÉs & & & \\
\hline sz1_ECDL_gy & 158 & 1,7297 & 0,28920 \\
\hline sz1_HOSSZU_gy & 156 & 1,1754 & 0,46170 \\
\hline sz1_DESIGN_gy & 159 & 1,0844 & 0,48516 \\
\hline sz1_EXTRA_gy & 152 & 0,6629 & 0,43903 \\
\hline Valid N (listwise) & 152 & & \\
\hline TÁBLÁzATKEZELÉS & & & \\
\hline t_ECDL_gy & 113 & 1,7388 & 0,36080 \\
\hline t_FGV_ALAP_gy & 113 & 1,1696 & 0,54892 \\
\hline t_MEGJELENIT_gy & 113 & 1,1272 & 0,49269 \\
\hline t_FGV_HALADO_gy & 110 & 0,6909 & 0,49496 \\
\hline t_EXTRA_gy & 110 & 0,3590 & 0,35269 \\
\hline Valid N (listwise) & 110 & & \\
\hline
\end{tabular}

Az új változók statisztikáiból látszik, hogy a legmagasabb átlagú és legkisebb szórású új változó mindkét területen az ECDL kategóriából jött létre. Ezeket a funkciókat gyakorlatilag mindenki gyakran használja, így az átlag megközelíti a maximális 2 értéket. Ebben a két csoportban föleg olyan eszközök szerepelnek, melyek használatát egy ECDL vizsgára való felkészüléssel el lehet sajátítani. Felvetődik a kérdés, hogy ezeket az ismereteket a felsőoktatás feladata-e megtanítani, vagy elvárható, hogy már a középiskolából ezekkel az ismeretekkel felvértezve jöjjenek a hallgatók, illetve elvárható-e az egyéni felzárkózás ezek hiányában. A hét, ECDL-ből hiányzó, ismeretet mindenképpen meg kell mutatni, bár azokat szintén legtöbbször már tudják a hallgatók (ezek szövegszerkesztésből a többszintű felsorolás, táblázat a szövegben és speciális nyomtatási beállítások, táblázatkezelésből pedig az egyéni számformátumok, irányított beillesztés, munkalapok elrejtése-felfedése és autoszürö).

1 fölötti átlaggal, de 1-hez közelebbi értékkel találkozunk még szövegszerkesztésnél a hosszú dokumentum és a designkategóriában, táblázatkezelésnél pedig az alapfüggvények és a megjelenítés kategóriában. Ezekben a csoportokban a szórás is nagyobb, többen 
vannak akik ezeket az eszközöket soha nem használják, de sokan vannak azok is, akiknek az értéke 1,5 fölötti, tehát inkább gyakran használják. A hosszú dokumentum csoportban csupa $\mathrm{P}$ kódú funkciót találunk, azaz ezek az ismeretek nem képezik részét az ECDL követelményeknek. A design, az alapfüggvények és a megjelenítés csoportban találunk mind E, mind P kódú funkciókat is. Ez a 4 csoport megerősíti azt az elképzelést, hogy a nálunk végző hallgatóknak bővebb ismeretekre van szükségük szövegszerkesztésből és táblázatkezelésből, mint az ECDL alapmoduljainak ismerete.
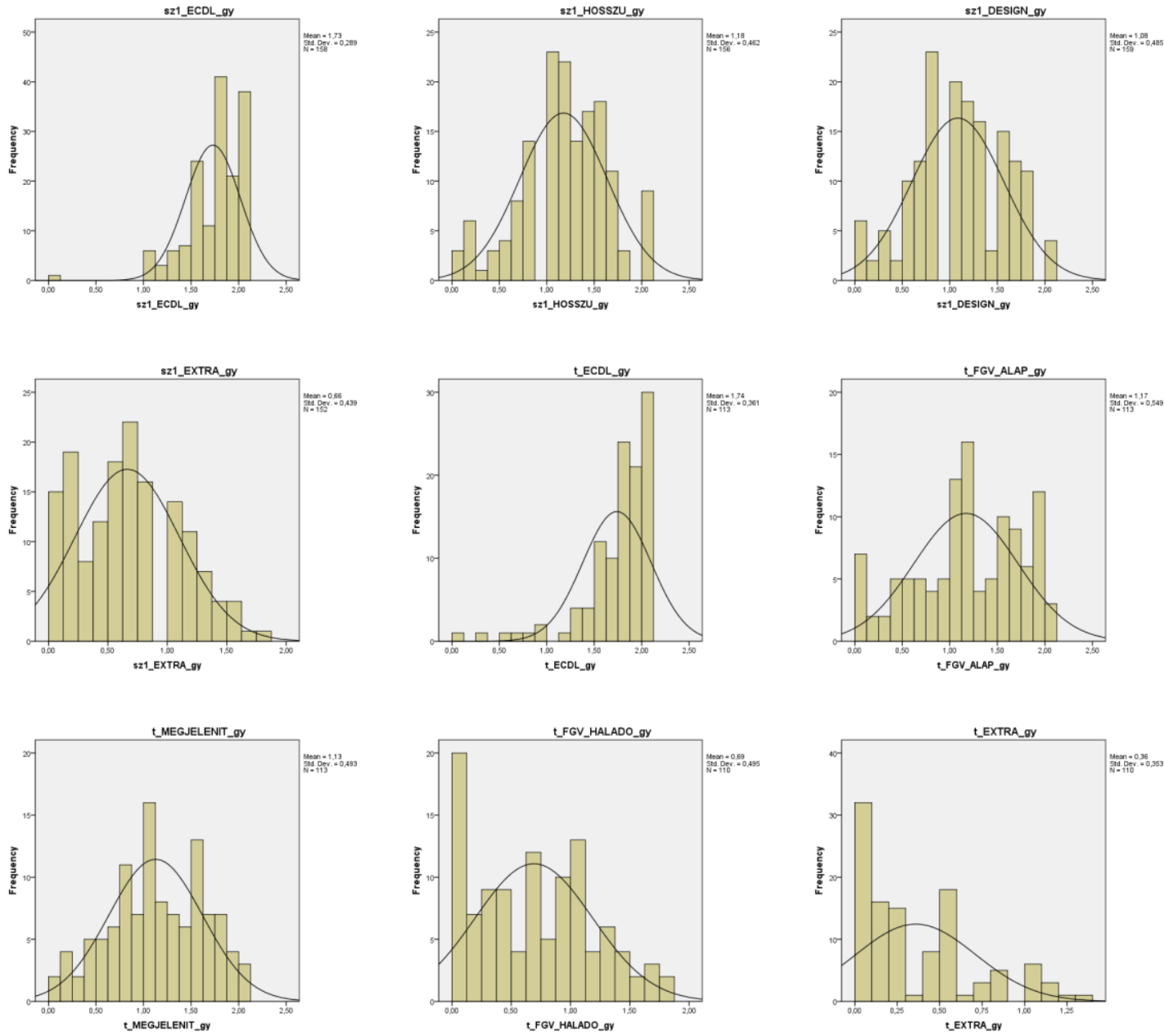

20. ábra Az összevont változók gyakorisági eloszlása, , ÁVF alumni 2012 (saját szerkesztés)

A maradék 3 kategória átlaga jóval 1 alatt van és a szórása sem olyan nagyon kicsi. Vannak olyan végzettek, akik ezeket az eszközöket egyáltalán nem használják és nagyon kevesen vannak olyanok, akik gyakran használják. Ezek a szövegszerkesztés extra kategóriája(itt a körlevélen kívül csak P kódú eszközök szerepelnek) és a táblázatkezelés haladó függvényekés extrakategóriája (ezekben csak P kódú eszközök szerepelnek). Megfontolandó, hogy ezeknek a tananyagban kell-e szerepelniük. Vajon azért nem használják, mert 
nem is lenne hasznos számukra, vagy csak azért, mert nem is ismerik őket, így nem tudják, hogy hasznos lenne-e? Erre a stabil használat vizsgálata után lehet majd megkísérelni a válaszadást.

A táblázatkezelö esetében nyitott kérdésben is rákérdeztem a leggyakrabban használt funkciókra. A 24. táblázat az említésszám alapján készült lista elejét mutatja.

24. táblázat A táblázatkezelő leggyakrabban használt funkciói, ÁVF alumni 2012 (saját szerkesztés)

\begin{tabular}{|c|c|}
\hline FUNKCIÓ & $\begin{array}{c}\text { EMLÍTÉS SZÁM } \\
\text { (91 VÁLASZOLÓBóL) }\end{array}$ \\
\hline SZUM & 69 \\
\hline HA & 41 \\
\hline FKERES & 38 \\
\hline DARABTELI & 25 \\
\hline ÁTLAG & 18 \\
\hline AUTOSZÜRÖ & 14 \\
\hline SZUMHA & 13 \\
\hline DARAB & 11 \\
\hline
\end{tabular}

\section{V.4.2. Budapesti Corvinus Egyetem alumni vizsgálat, 2013-14}

A korábbi, ÁVF-es kutatás tanulságai alapján átalakított kérdőívet elektronikus úton próbáltam eljuttatni minél több corvinusos végzett hallgatóhoz. Összesen 168 használható kérdőívet kaptam (a nagyon hiányos és a nem gazdaságtudományokhoz tartozó szakon végzettek által kitöltött kérdőívek kihagyása után). A kérdőívet eredetileg az elmúlt években (2009-2011) végzett, már a bolognai rendszerben tanultakkal akartam kitöltetni, de később kiterjesztettem minden korábban végzettre is. A 168 fő semmilyen szempontból nem tekinthető reprezentatív mintának, ahhoz mégis elég nagy, hogy bizonyos következtetéseket levonhassunk belöle. A kutatásnak egy járulékos tanulsága, hogy a BCE-n az alumnival nem igazán szoros a kapcsolat, az informális utakon (Facebook, e-mail) eljuttatott felhívásokra sokkal több kitöltés érkezett, mint az alumni rendszeren keresztült történtekre.

A válaszadók megoszlása főszakirányuk, illetve szakjuk alapján a 25. táblázatban látható. A Bologna utáni szakok (2009-ben, vagy utána végzettek) közül az Emberi erőforrások szakról egyetlen kitöltő sem volt. A Bologna elötti szakok megnevezése nem biztos, hogy minden esetben teljesen pontos. 
DOI: $10.14267 /$ phd.2014081

25. táblázat A válaszadók szakjai és szakirányai, BCE alumni, 2013-14 (saját szerkesztés)

\begin{tabular}{|l|r|}
\hline \multicolumn{2}{|c|}{ BOLOGNA UTÁNI SZAKOK } \\
\hline alkalmazott közgazdaságtan & 7 \\
\hline gazdálkodási és menedzsment & 32 \\
\hline gazdaságelemzés & 5 \\
\hline kereskedelem és marketing & 3 \\
\hline közszolgálati & 3 \\
\hline nemzetközi gazdálkodás & 5 \\
\hline pénzügy és számvitel & 19 \\
\hline turizmus-vendéglátás & 14 \\
\hline Összesen: & $\mathbf{8 8}$ \\
\hline
\end{tabular}

\begin{tabular}{|l|r|}
\hline \multicolumn{2}{|c|}{ BOLOGNA ELŐTTI SZAKIRÁNYOK } \\
\hline belkereskedelmi & 3 \\
\hline ellátási-lánc menedzsment & 1 \\
\hline EU integráció & 1 \\
\hline gazdálkodási szak & 1 \\
\hline gazdaságelmélet & 1 \\
\hline információgazdálkodás & 7 \\
\hline International study center & 1 \\
\hline ipari szervező & 1 \\
\hline iparvállalatok szervezése és irányítása & 3 \\
\hline közszolgálati & 3 \\
\hline külgazdaság & 6 \\
\hline marketing & 4 \\
\hline nemzetközi kapcsolatok & 5 \\
\hline nemzetközi kereskedelem & 1 \\
\hline népgazdaság tervezö elemzö & 1 \\
\hline pénzügy & 7 \\
\hline pénzügyi befektetéselemző és kockázatkezelő & 4 \\
\hline piacelemző & 2 \\
\hline számvitel & 7 \\
\hline szolgáltatásmenedzsment & 3 \\
\hline tanár & 7 \\
\hline vállalati pénzügy & 2 \\
\hline vezetés-szervezés & 3 \\
\hline gazdaságmatematikai elemző közgazdász \\
\hline Összesen: & 2 \\
\hline NEM BEsoROLHATó & 2 \\
\hline
\end{tabular}

A Bologna előtti szakoknál megnéztem a végzés éve szerinti eloszlást is. A 21. ábra azt a 72 volt hallgatót mutatja, akik kitöltötték a végzés évét.A 2004-es kiugró érték oka az lehet, hogy személyes hálózaton keresztül is terjesztettem a kérdőívet és én is 2004-ben végeztem. 5 és 4 válaszadó 2009-ben illetve 2010-ben végzett, valószínüleg halasztottak a tanulmányaik során. 


\section{A Bologna előtti szakosok megoszlása a végzés éve szerint}

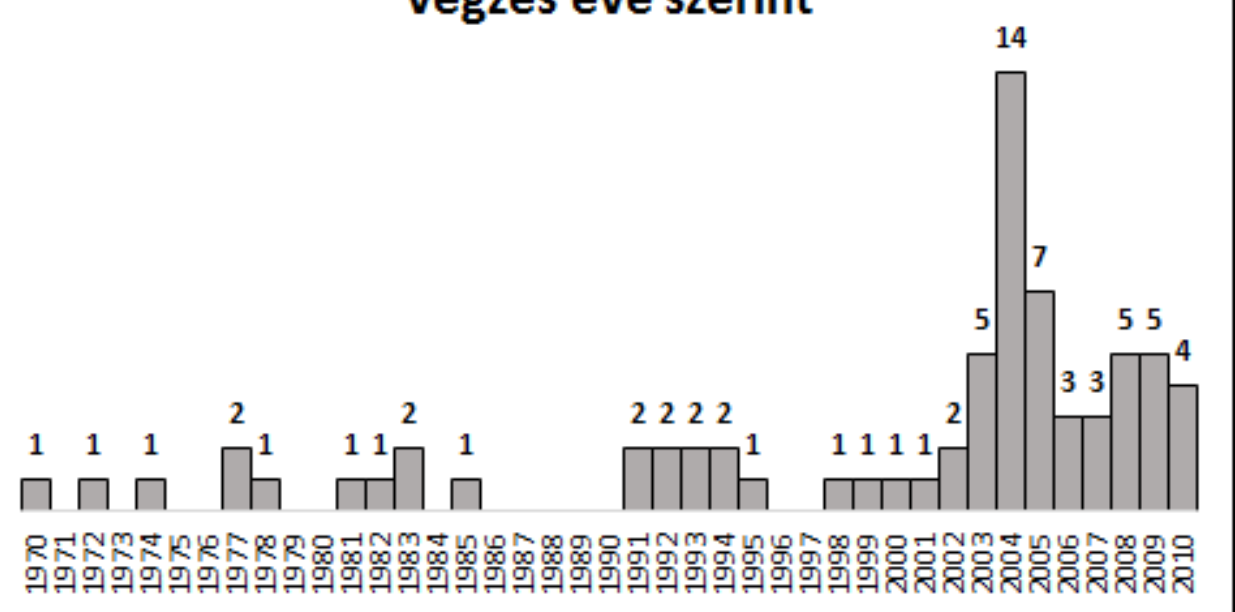

21. ábra A válaszadók végzésének éve, BCE alumni, 2013-14 (saját szerkesztés)

A kitöltők nagy többsége nappali tagozaton végzett, mindössze 3 levelezős (bolognais) és 5 esti tagozatos ( 2 korábbi és 3 bolognais) volt a kitöltők között.

\section{V.4.2.1. A 2012-es ÁVF és a 2013-14-es BCE kutatás eredményeinek ösz- szehasonlítása}

Voltak bizonyos kérdések, amelyek gyakorlatilag változtatás nélkül bennemaradtak a kérdőívben. Ezek elemzése lehetőséget ad az összehasonlításra.

26. táblázat A cég mérete, és a kitöltők beosztása, BCE alumni, 2013-14 (saját szerkesztés)

\begin{tabular}{|l|r|r|r|r|r|r|}
\hline & - & $\begin{array}{r}\text { FELSŐ- } \\
\text { VEZETö }\end{array}$ & $\begin{array}{r}\text { KÖZÉP- } \\
\text { VEZETö }\end{array}$ & BEOSZTOTT & $\begin{array}{r}\text { ÖNFOGLAL- } \\
\text { KOZTATÓ/ } \\
\text { VÁLLALKOZÓ }\end{array}$ & TOTAL \\
\hline- & $1,79 \%$ & $0,00 \%$ & $0,00 \%$ & $0,60 \%$ & $0,00 \%$ & $2,38 \%$ \\
\hline $\begin{array}{l}\text { mikro (10 fönél } \\
\text { kevesebb dolgozó) }\end{array}$ & $0,60 \%$ & $2,98 \%$ & $1,19 \%$ & $4,76 \%$ & $2,38 \%$ & $11,90 \%$ \\
\hline $\begin{array}{l}\text { kis (50 főnél } \\
\text { kevesebb dolgozó) }\end{array}$ & $0,60 \%$ & $0,60 \%$ & $0,60 \%$ & $10,12 \%$ & $0,00 \%$ & $11,90 \%$ \\
\hline $\begin{array}{l}\text { közép (250 fönél } \\
\text { kevesebb dolgozó) }\end{array}$ & $0,60 \%$ & $1,19 \%$ & $3,57 \%$ & $11,31 \%$ & $0,00 \%$ & $16,67 \%$ \\
\hline $\begin{array}{l}\text { nagy (250 } \\
\text { dolgozónál több) }\end{array}$ & $1,19 \%$ & $2,38 \%$ & $14,29 \%$ & $39,29 \%$ & $0,00 \%$ & $57,14 \%$ \\
\hline Total & $4,76 \%$ & $7,14 \%$ & $19,64 \%$ & $66,07 \%$ & $2,38 \%$ & $100 \%$ \\
\hline
\end{tabular}


A 26. táblázatban látható az egyetemi kitöltők megoszlása aszerint, hogy milyen beosztásban dolgoznak és milyen méretü vállalatnál. A föiskolaiakhoz hasonlóan a legtöbben beosztottak és nagyvállalatnál dolgoznak.

Arra, hogy milyen módon ellenőrizték az informatikai ismereteket a BCE alumniból 165en válaszoltak összesen, közülük 159-en jelöltek meg valamilyen követelményt $(96,36 \%)$.

48,78\%-nak szerepelt az álláshirdetésében, 47,56\%-nak az állásinterjún kérdeztek rá, írásbeli tesztet mindössze 4,88\%-kal töltettek ki, de gyakorlati felmérés is csak 13,41\%nál fordult elö.

Az ÁVF alumni válaszadói közül 54,5\%-nál volt a munkahelyi felvételinél elvárás az informatikai kompetencia. Náluk is a többségnél az állásinterjún kérdeztek rá, gyakorlati tesztet csak 14,20\%-nak kellett kitölteni.

Ezekből az adatokból arra következtetek, hogy a munkáltatók alapértelmezettnek veszik az informatikai kompetencia meglétét, többnyire nem ellenőrzik azt külön a felvételi eljárás során, maximum rákérdeznek.

Az egyetemi válaszadók között voltak több évtizede végzettek is. A 27. táblázat azt mutatja, hogy a 2000-ben vagy utána végzetteknél kisebb azok aránya, akiknél egyáltalán nem volt ilyen követelmény, míg a 70-es években végzettek felének nem volt. (A részminták a korábbi éveknél kicsik, de az eltérések elég meggyőzőek.)

27. táblázat $A$ végzés évtizede és az informatikai követelmény aránya a munkahelyi felvételi eljárásban, BCE alumni, 2013-14 (saját szerkesztés)

\begin{tabular}{|c|r|r|c|}
\hline $\begin{array}{c}\text { VÉGZÉS } \\
\text { ÉVE }\end{array}$ & \multicolumn{1}{|c|}{ Fő } & $\begin{array}{c}\text { NEM VOLT } \\
\text { KÖVETELMÉNY }\end{array}$ & \multicolumn{1}{l|}{ ARÁNY } \\
\hline $1970-1979$ & 6 & 3 & $50,00 \%$ \\
\hline $1980-1989$ & 5 & 2 & $40,00 \%$ \\
\hline $1990-1999$ & 11 & 3 & $27,27 \%$ \\
\hline $2000-2009$ & 62 & 8 & $12,90 \%$ \\
\hline $2010-2014$ & 56 & 10 & $17,86 \%$ \\
\hline Végösszeg & 140 & 26 & $18,57 \%$ \\
\hline
\end{tabular}

Az elvárt tudásnál az első helyezettek sorrendje megegyezik a korábbi főiskolai kutatás eredményével, az arányok viszont magasabbak. Az adatbázis-kezelés az ottani egy harmados említéshez képest valamivel alacsonyabb, 28,57\%. 
DOI: $10.14267 /$ phd.2014081

28. táblázat A munkahelyi felvételi eljárásban szereplő informatikai követelmények elöfordulási aránya, BCE alumni, 2013-14 (saját szerkesztés)

\begin{tabular}{|l|r|r|}
\hline \multicolumn{1}{|c|}{ ELVÁRT TUDÁS } & EMLÍTÉSSZÁM & EMLÍTÉSI ARÁNY \\
\hline Táblázatkezelés & 147 & $87,50 \%$ \\
\hline Szövegszerkesztés & 132 & $78,57 \%$ \\
\hline Internet használat & 115 & $68,45 \%$ \\
\hline Prezentációkészítés & 103 & $61,31 \%$ \\
\hline Operációs rendszer ismeret & 70 & $41,67 \%$ \\
\hline Adatbázis-kezelés & 48 & $28,57 \%$ \\
\hline Integrált vállalatirányítási rendszer ismerete & 30 & $17,86 \%$ \\
\hline Hardver ismeret & 16 & $9,52 \%$ \\
\hline Programozás & 16 & $9,52 \%$ \\
\hline Honlap-szerkesztés & 11 & $6,55 \%$ \\
\hline Hálózati technológiák ismerete & 9 & $5,36 \%$ \\
\hline project management & 1 & $0,60 \%$ \\
\hline SAP BW/BI & 1 & $0,60 \%$ \\
\hline statisztikai, adatbányászati szoftverek & 1 & $0,60 \%$ \\
\hline
\end{tabular}

A főiskolai válaszolókhoz hasonlóan a válaszadók több mint háromnegyede idejének több mint háromnegyedét a számítógép elött tölti (17. ábra vs. 22.ábra).

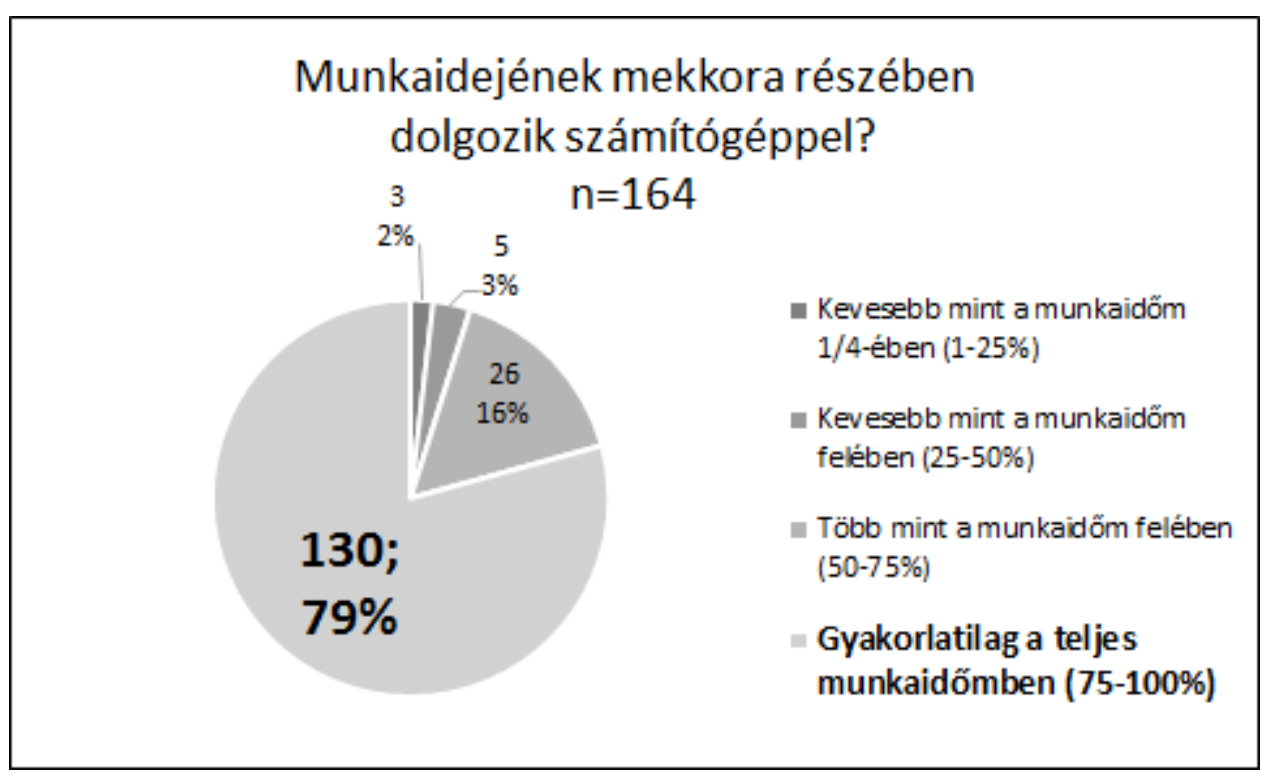

22. ábra Számítógép előtt töltött munkaidő, BCE alumni, 2013-14 (saját szerkesztés) 
DOI: $10.14267 /$ phd.2014081

29. táblázat Számítógépes munkavégzés jellege, BCE alumni, 2013-14 és ÁVF alumni 2012 összehasonlítás (saját szerkesztés)

\begin{tabular}{|c|c|c|c|c|}
\hline FELADAT & $\begin{array}{c}\text { BCE } \\
\text { EMLÍTÉSSZÁM }\end{array}$ & $\begin{array}{c}\text { BCE } \\
\text { EMLÍTÉSI } \\
\text { ARÁNY } \\
\end{array}$ & $\begin{array}{l}\text { ÁVF } \\
\text { EMLÍTÉSI } \\
\text { ARÁNY }\end{array}$ & $\begin{array}{l}\text { ELMOZ- } \\
\text { DULÁS }\end{array}$ \\
\hline Cégen belüli kommunikáció & 129 & $76,33 \%$ & $78,80 \%$ & $\Rightarrow$ \\
\hline Prezentációk készítése & 116 & $68,64 \%$ & kimaradt & \\
\hline $\begin{array}{l}\text { Táblázatkezelővel kimutatások, } \\
\text { elemzések, összesítések készítése }\end{array}$ & 115 & $68,05 \%$ & $63,60 \%$ & 仑 \\
\hline $\begin{array}{l}\text { Táblázatkezelővel adatlisták } \\
\text { készítése, kezelése }\end{array}$ & 114 & $67,46 \%$ & $74,70 \%$ & Љ \\
\hline Kommunikáció az interneten & 101 & $59,76 \%$ & $66,70 \%$ & \& \\
\hline Szöveges feljegyzések készítése & 94 & $55,62 \%$ & $55,60 \%$ & $\Rightarrow$ \\
\hline $\begin{array}{l}\text { Szövegszerkesztővel hivatalos } \\
\text { levelek írása }\end{array}$ & 88 & $52,07 \%$ & $67,70 \%$ & \& \\
\hline $\begin{array}{l}\text { Táblázatkezelővel modellezések, } \\
\text { számítások végzése }\end{array}$ & 79 & $46,75 \%$ & $33,30 \%$ & 认 \\
\hline Cégirányítási szoftver használata & 48 & $28,40 \%$ & $31,80 \%$ & $\Rightarrow$ \\
\hline $\begin{array}{l}\text { Szövegszerkesztővel rövid } \\
\text { kiadványok (pl. meghívó, plakát, } \\
\text { programfüzet) készítése }\end{array}$ & 41 & $24,26 \%$ & $23,70 \%$ & $\Rightarrow$ \\
\hline $\begin{array}{l}\text { Céges adatbázis kezelése } \\
\text { adatbázis-kezelővel }\end{array}$ & 40 & $23,67 \%$ & $26,30 \%$ & $\Rightarrow$ \\
\hline $\begin{array}{l}\text { Cégnyilvántartási szoftverek } \\
\text { használata }\end{array}$ & 35 & $20,71 \%$ & $27,80 \%$ & \& \\
\hline $\begin{array}{l}\text { Szövegszerkesztővel hosszú } \\
\text { kiadványok (pl. tanulmányok, } \\
\text { konferenciakötetek) készítése }\end{array}$ & 34 & $20,12 \%$ & $12,10 \%$ & 认 \\
\hline $\begin{array}{l}\text { Döntéstámogató szoftverek } \\
\text { használata }\end{array}$ & 30 & $17,75 \%$ & $11,60 \%$ & 仓 \\
\hline Képszerkesztés & 25 & $14,79 \%$ & $21,20 \%$ & \& \\
\hline Könyvelés könyvelő programmal & 24 & $14,20 \%$ & $22,20 \%$ & \& \\
\hline $\begin{array}{l}\text { Céges adatbázis létrehozása, } \\
\text { karbantartása adatbázis-kezelővel }\end{array}$ & 14 & $8,28 \%$ & $9,10 \%$ & $\Rightarrow$ \\
\hline Webszerkesztés & 13 & $7,69 \%$ & $7,10 \%$ & $\Rightarrow$ \\
\hline Számlázás táblázatkezelővel & 10 & $5,92 \%$ & $11,60 \%$ & $\Rightarrow$ \\
\hline
\end{tabular}


A kutatásban fontos kérdés volt, hogy milyen feladatokra használják a számítógépet a munkahelyükön. A 29. táblázat összehasonlításban mutatja az egyetemi és a föiskolai válaszokat.

A tanszéki interjúk során láttuk az előző kutatásban, hogy az oktatók más elvárásokat fogalmaztak meg a főiskolán és az egyetemen. A két intézmény tanterveinek összehasonlításakor is láttuk az eltérést. Kíváncsi voltam rá, hogy ez az eltérés a munkahelyen is megjelenik-e a föiskolát és az egyetemet végzettek között, azaz hogy jogos-e, hogy más az elvárás a két intézményben. Az egyetemet végzettek körében többek készítenek a munkahelyükön táblázatkezelővel kimutatásokat, elemzéseket, összesítéseket, táblázatkezelővel modellezéseket, számításokat (itt volt a legnagyobb eltérés), szövegszerkesztővel hosszú kiadványokat és döntéstámogató szoftvereket. A két utóbbi az egyetemet végzettek körében is csak $20 \%$ körül van.

A BCE végzettjei közül 94-en említettek olyan programokat, amelyekkel dolgoznak, de az aktuális munkahelyre kerülésük előtt nem ismerték (fejenként átlagosan kettőt). A leggyakoribbak a 30. táblázatban, megjegyezve, hogy különböző SQL szerkesztőket még 5en említettek. A céges programok, banki szoftverek, saját fejlesztésü programok csoportjába még jó néhány további konkrétan megnevezett program kerülhetne be. (A föiskolán is az SAP-t a Lotus Notes-ot és a saját fejlesztésü, illetve céges egyedi programokat említették többen. Ott többször említésre került még a Kulcs-soft könyvelö program is.)

30. táblázat A munkahelyen használt, korábban nem ismert programok említésszáma, BCE alumni, 2013-14 (saját szerkesztés)

\begin{tabular}{|l|r|}
\hline \multicolumn{1}{|c|}{ SzOFTVER } & EMLÍTÉSSZÁM \\
\hline SAP & 25 \\
\hline Lotus Notes & 9 \\
\hline Oracle PL/SQL Developer & 9 \\
\hline SAS & 7 \\
\hline céges programok & 7 \\
\hline SPSS & 4 \\
\hline banki szoftverek & 3 \\
\hline Microsoft Sharepoint & 3 \\
\hline saját fejlesztésű programok & 3 \\
\hline
\end{tabular}

Mindkét vizsgálatban rákérdeztem arra is, hogy mi módon tanulták meg, amit korábban nem ismertek (31. táblázat). Az autodidakta mód említése viszonylag magas, főleg ha 
figyelembe vesszük, hogy az egyetemen a kitöltőknek eleve csak az 55\%-a említette, hogy egyáltalán volt olyan program, amit korábban nem tanult. A hasonló program analógiája viszont elég alacsony értéket kapott mindkét iskola végzettjei között.

31. táblázat A munkahelyen használt, korábban nem ismert programok említésszáma, BCE alumni, 2013-14 (saját szerkesztés)

\begin{tabular}{|l|r|r|r|r|}
\hline \multicolumn{1}{|c|}{ TANULÁSI MóD } & BCE & ARÁNY & ÁVF & ARÁNY \\
\hline kollégák & 72 & $42,60 \%$ & 75 & $63,56 \%$ \\
\hline $\begin{array}{l}\text { autodidakta módon (kipróbálással, súgó } \\
\text { segítségével) }\end{array}$ & 62 & $36,69 \%$ & 64 & $54,24 \%$ \\
\hline munkahelyi tanfolyam & 33 & $19,53 \%$ & 34 & $28,81 \%$ \\
\hline hasonló program analógiája & 15 & $8,88 \%$ & 14 & $11,86 \%$ \\
\hline tankönyv & 2 & $1,18 \%$ & 2 & $1,69 \%$ \\
\hline külső tanfolyam & 1 & $0,59 \%$ & 9 & $7,63 \%$ \\
\hline felhasználói gondolkodás az egyetemről & 1 & $0,59 \%$ & & \\
\hline egyéb & & & 4 & $3,39 \%$ \\
\hline
\end{tabular}

\section{V.4.2.2. Informatikai feladatok végzésének gyakorisága és stabilitása}

A bejövő hallgatók kérdőívéből már ismert 15 informatikai feladatra az egyetemi alumni körében is rákérdeztünk. A pontos kérdés így szólt. „Jelölje minden sorban, hogy az alábbi feladatokat milyen gyakran és milyen stabilan végzi!” A lehetséges válaszok pedig:gyakran (2), ritkán (1), soha (0) illetve önállóan, gyorsan, rutinból (2), sok hibával, kísérletezéssel (1) és nem ismerem (0). A stabilitás megítélésénél ugyanúgy, mint a hallgatói kérdőív kielemzésénél, a saját átlagtól vett eltérésre konvertáltam a válaszokat és az elemzéseket ez alapján végeztem el. A válaszok átlagai a 32. táblázatban láthatóak. A gyakori használatnál 1-nél nagyobb átlagot az internethasználat, a különböző táblázatkezelési és szövegszerkesztési feladatok és a prezentációkészítés kaptak. A többi feladatkör és a táblázatkezelő és a szövegszerkesztő haladó használata valamint a kiadványkészítés átlaga 1 alatti, vagyis ritkán, vagy soha nem végzik ezeket a feladatokat. Nem meglepő módon a gyakran végzett feladatokat az átlagosnál stabilabban végzik (erre utalnak a pozitív értékek a 3. oszlopban). A ritkán végzett feladatok közül egyedül a kiadvány készítésénél van pozitív érték.

\section{V.4.2.3. Klaszterelemzés}

Klaszterelemzéssel csoportokat képeztem a kitöltőkből az alapján, hogy a vizsgált 15 feladatot milyen gyakran végzik. A klaszterelemzést összesen 12-szer futtattam 3 féle sorba 
rendezéssel és 2, 3, 4 és 5 klaszterre osztva a csoportot. 105 olyan kitöltő volt, aki mind a 15 kérdésre választ adott, őket tudtam bevonni az elemzésbe. Egyedül a 3 klaszteres futtatásoknál nem változtatta meg a végeredményt az adatok kiinduló sorrendjének változtatása, így elfogadható, hogy a kitöltők 3 csoportra oszthatók. Az egyes csoportokba 39, 36 illetve 30 fö került.

Nézzük meg a 3 csoport jellemzőit a vizsgált 15 feladat szempontjából. A klaszterközepek alapján a 3 csoportot a következőképpen neveztem el: adatkezelö (39 fö), informatika orientált (30 fó) és egyszerü felhasználó (36 fö). A klaszterközepek a 32. táblázatban láthatók. Két feladatnál nincs szignifikáns különbség a 3 csoport között, ezek a táblázatkezelővel táblázat készítése illetve az internethasználat. Mindkettő nagyon magas értékeket kapott mindhárom csoportban. Emlékeztetőül az értékek jelentése: 0 - soha nem végzi, 1 - ritkán, 2 - gyakran.

Az egyszerü felhasználók csoportjában magas érték tartozik még a szövegszerkesztővel egyszerü szöveg készítéséhez és viszonylag magas a hosszú dokumentumhoz (ebben második helyezett az 1,36-os értékkel). 1 fölötti érték szerepel még $(1,28)$ a táblázatkezelövel egyszerü képletek készítésénél és a prezentációkészítésnél.

Az adatkezelőknél nagyon magas értéket kapott a táblázatkezelővel egyszerü képletek és haladó függvények használata illetve az adatelemzés. Magas, de a másik két csoportétól elmaradó érték szerepel a szövegszerkesztővel egyszerü szöveg készítésénél (1,44 az 1,86-1,87 mellett). Egyedül a prezentációkészítés kapott még 1-nél nagyobb értéket, de az is elmarad a másik két csoportétól (1,1 az 1,28 és 1,70 mellett). A táblázatkezelő haladó használatában második helyezett, 1-hez közeli értékkel $(0,82)$.

Az informatikaorientált csoportban szerepel a legtöbb magas érték. 1 alatti értékek csak a webszerkesztés, multimédiaszerkesztés és programozás feladatoknál vannak, utóbbi magasan veri a másik két csoportot ( 0,87 a 0,05 és 0,03 mellett). Minden feladatnál első helyezett, vagy nincs értékelhető lemaradásban a második helyen (a legnagyobb különbség az adatkezelő csoport javára a táblázatkezelővel egyszerü képletek használata, de ott is csak 6 század a különbség). 
DOI: $10.14267 /$ phd.2014081

32. táblázat Az informatikai feladatok gyakorisága alapján képzett klaszterek klaszterközepei, BCE alumni, 2013-14 (saját szerkesztés)

\begin{tabular}{|l|r|r|r|}
\hline & ADATKEZELŐ & $\begin{array}{c}\text { INFORMATIKA } \\
\text { - ORIENTÁLT }\end{array}$ & $\begin{array}{c}\text { EGYSZERÜ } \\
\text { FELHASZNÁLÓ }\end{array}$ \\
\hline $\begin{array}{l}\text { Szövegszerkesztővel egyszerü } \\
\text { szöveg készítése }\end{array}$ & 1,44 & 1,87 & 1,86 \\
\hline $\begin{array}{l}\text { Szövegszerkesztővel hosszú } \\
\text { dokumentum készítése }\end{array}$ & 0,72 & 1,63 & 1,36 \\
\hline $\begin{array}{l}\text { Szövegszerkesztővel kiadvány } \\
\text { készítése }\end{array}$ & 0,31 & 1,10 & 0,83 \\
\hline $\begin{array}{l}\text { Szövegszerkesztő haladó } \\
\text { használata }\end{array}$ & 0,26 & 1,17 & 0,69 \\
\hline $\begin{array}{l}\text { Táblázatkezelővel táblázat } \\
\text { készítése }\end{array}$ & 1,95 & 1,93 & 1,86 \\
\hline $\begin{array}{l}\text { Táblázatkezelővel egyszerü } \\
\text { képletek, függvények használata }\end{array}$ & 1,92 & 1,87 & 1,28 \\
\hline $\begin{array}{l}\text { Táblázatkezelővel haladó } \\
\text { függvények }\end{array}$ & 1,74 & 1,77 & 0,50 \\
\hline Táblázatkezelővel adatok elemzése & 1,92 & 1,90 & 0,72 \\
\hline Táblázatkezelő haladó használata & 0,82 & 1,43 & 0,06 \\
\hline Prezentációkészítés & 1,10 & 1,70 & 1,28 \\
\hline Internethasználat & 1,95 & 1,97 & 2,00 \\
\hline Webszerkesztés & 0,05 & 0,30 & 0,14 \\
\hline Multimédia szerkesztés & 0,23 & 0,67 & 0,42 \\
\hline Adatbázis-kezelés & 0,67 & 1,23 & 0,36 \\
\hline Programozás & 0,05 & 0,87 & 0,03 \\
\hline
\end{tabular}

Megvizsgáltam, hogy az egyéb tulajdonságokban felfedezhető-e különbség a csoportok között. A tantárgyak tartalmának kidolgozásánál a szakok közötti eltérés lehet izgalmas. A bolognai folyamatban végzetteknél vizsgáltam meg, hogy az egyes klaszterekbe hányan kerültek a közgazdasági és az üzleti szakokról. Mivel az egyes részminták nagyon kicsik, ezeket az eredményeket nagyon óvatosan szabad csak kezelni, tényleg inkább csak érdekességként. A közgazdasági szakterületen a 11 besorolt válaszadó közül csak 2 került az egyszerü felhasználói csoportba (18\%), 3 az adatkezelőbe (27\%) és 6 az informatikaorientáltba (55\%). Az üzleti szakterületen 42 kitöltőt lehetett besorolni, 15 fö egyszerü 
felhasználó (36\%), 17 fö adatkezelö (40\%) és 10 fő informatikaorientált (24\%). Megállapítható, hogy bár van eltérés a két csoport között, a kis részminták miatt ezekből az eltérésekből messzemenő következtetést nem lehet levonni.

Megvizsgáltam még a végzés éve szerinti eltérést a csoportok között. Az egyszerü felhasználók szignifikánsan korábban végeztek, mint az adatkezelők és az informatikaorientáltak. A 2000 előtt végzettek 71,43\%-a egyszerü felhasználó, míg a később végzettek között ez az arány csak 31,17\%.

\section{V.4.2.4. A nyílt kérdésekre adott válaszok elemzése}

A kérdőív végén 5 nyílt kérdésben lehetőségük nyílt a kitöltőknek bővebben kifejteni a véleményét. Ezek a kérdések így szóltak:

- Mit tartott jónak az egyetemi informatika képzésben? Írja le néhány mondatban, vagy címszavakban!

- Mit hasznosított leginkább az egyetemen informatikából tanultakból? Írja le néhány mondatban, vagy címszavakban!

- Mit hiányolt az egyetemi informatika képzésből? Írja le néhány mondatban, vagy címszavakban!

- Mit tart feleslegesnek az egyetemi informatika képzésben? Írja le néhány mondatban, vagy címszavakban!

- Ha eszébe jutott bármi a kérdőív témájával kapcsolatban, amit fontosnak talál, de a kötött válaszokban nem tudta elmondani, itt leírhatja.

A kitöltők 65\%-a élt is ezzel a lehetőséggel és legalább egy nyílt kérdésre válaszolt. A válaszok közül néhány egyértelmü tendenciát emelnék ki. A régebben végzettek leírták, hogy nem igazán tudnak releváns válaszokat adni ezekre a kérdésekre.

A pozitív kérdésekre a leggyakoribb válasz az Excel volt, de míg arra, hogy mit tartott jónak a válaszolók alig több mint 10\%-a említette a táblázatkezelést valamilyen módon, addig arra, hogy mit hasznosított leginkább, a válaszolók közel fele ezt említette meg. A válaszolók 20\%-a azt állítja, hogy semmit nem hasznosít.

A hiánynál a leggyakoribb válaszok a több Excel (24\%), gyakorlatiasság (17\%), adatbázis (12\%), szélesebb rálátás (12\%), makrók (12\%), prezentáció (10\%), szövegszerkesztés (8\%). Feleslegesnek a válaszolók 32\%-a az elméletet, illetve az előadásokat tartotta, 16\% pedig a programozást. 
Különböző kérdésekre adott válaszokban, de szintén többeknél elökerült az alapok felesleges, vagy túl sok időt igénybe vevő ismétlése, megtanítása is.

\section{V.4.3. Az alumni kutatások eredményeinek összefoglalása}

A kutatások során arra kerestem a választ, hogy milyen informatikai ismeretekre van szükségük a gazdálkodástani felsőoktatásban részt vevő hallgatóknak. Az ÁVF végzettjei körében végzett kérdőíves felmérésből kiderült, hogy a cégen belüli és kívüli kommunikáció mellett a szövegszerkesztés és táblázatkezelés a két legfontosabb informatikai terület. Ezek részét képezik az ECDL követelményeknek és a föiskolai tananyagnak is. A kutatás során mindkét területet részleteiben is felmértem, és a válaszok alapján homogénebb csoportokat képeztem a részterületekböl. Ezek részletesebb vizsgálata megmutatta, hogy bár a leggyakrabban használt eszközök nagy része szerepel az ECDL követelmények között, de volt összesen 7 olyan ECDL-en kívüli típusfeladat, ami az elemzés során ugyanabba a kategóriába került, mint a leggyakrabban használt ECDL-ben is tanított feladatok. Ezen kívül 2-2 szövegszerkesztési és táblázatkezelési feladatkategóriában nagy számban vannak ECDL-en kívüli funkciók, amiket szintén sokan használnak gyakran. Megállapítottam tehát, hogy az ECDL alapmodulok tananyaga csak részben illeszkedik a munkahelyi követelményekhez, így csak ezek ismerete kevés.

A két kutatás néhány kérdésben hasonló eredményeket hozott. Egyrészt mindkét intézmény végzettjeinek háromnegyed a munkaideje jelentős részét tölti számítógép előtt. Másrészt a munkahelyek által támasztott elvárások is hasonló képet mutattak. Az internethasználat, táblázatkezelés, szövegszerkesztés és prezentációkészítés a legfontosabbak. A munkahelyi felvételi eljárás során többnyire csak az álláshirdetésben szerepeltek ezek az elvárások, vagy az interjún kérdeztek rájuk. A munkáltatók alapértelmezettnek veszik az informatikai kompetencia meglétét, többnyire nem ellenőrzik azt külön a felvételi eljárás során, maximum rákérdeznek.

A munkahelyen végzett feladatok között mutatkozott eltérés a főiskolai és egyetemi végzettségűek között. A legnagyobb különbség a táblázatkezelővel kimutatások, elemzések illetve modellezések készítése között volt az egyetemisták javára.

A munkahely előtt nem ismert programok között különböző vállalati szoftvereket említettek. A legnagyobb említésszámmal az SAP szerepelt (25\%). A nem ismert programok megtanulása többnyire a kollégák segítségével és autodidakta módon történt. Mindkét 
kutatásban alacsony volt a hasonló program analógiájának megjelölése (11,86\% illetve $8,88 \%)$.

Az egyetemi kutatás több elemzésre adott lehetőséget. Kimutatható volt, hogy a korábban végzetteknél kisebb volt azok aránya, akiknél volt informatikai elvárás, illetve a klaszterelemzés során kialakult csoportok közül a korábban végzettek nagyobb része került az egyszerü felhasználók csoportjába.

Az egyetemi kutatásban az egyes informatikai feladatok közül az internethasználat, a különböző táblázatkezelési és szövegszerkesztési feladatok és a prezentációkészítés gyakorisága emelkedett ki. A gyakran végzett feladatokat az átlagosnál stabilabban is végzik a kitöltők.

Klaszterelemzéssel 3 csoportba osztottam a mintát: egyszerü felhasználók, adatelemzők, informatikaorientáltak. Az egyes szakokon végzett hallgatók részmintái annyira kicsik, hogy azokra vonatkozóan nem lehet egyértelmü következtetéseket levonni. Az időbeli eltérés azonban szignifikáns, az egyszerü felhasználók a korábban végzetteknél vannak inkább túlsúlyban.

A nyílt kérdésekre adott válaszokból az derül ki, hogy egyrészt hasznosnak találták a táblázatkezelő oktatását, másrészt hiányosnak, több, mélyebb tudást szerettek volna szerezni. A hiányosságoknál merült fel a legtöbb felvetés, úgy mint adatbázis-kezelés, makrózás, prezentációkészítés, szövegszerkesztés. A tartalmi kérdések mellett módszertani, szemléletbeli hiányosságokat is említettek, úgy mint a gyakorlatiasság illetve a szélesebb körü rálátás. Feleslegesnek a legtöbben az elméleti előadásokat tartották, legalábbis abban a formában és azzal a tartalommal, ahogy nekik tartották őket.

\section{V.5. A bejövő hallgatók és az alumni körében végzett felmérés összevetése}

A kérdőívek tervezésénél nagy gondot fordítottam arra, hogy a részletes kérdéseknél ugyanazok a feladatcsoportok szerepeljenek, így lehetőség nyílt a bejövő hallgatók és a dolgozók kompetenciáinak összehasonlítására. Az eredmény tisztán megmutatja, hogy azok közül a feladatok közül, amiket a dolgozók gyakran végeznek melyikek azok, amelyeket már a bejövő hallgatók is nagy valószínűséggel tudnak, és melyek azok, amelyekben lemaradásuk van (33. táblázat). Ez utóbbiakra kell a felsőoktatásnak koncentrálnia. 
DOI: $10.14267 /$ phd.2014081

33. táblázat Eltérés az alumni és a bejövő hallgatók kompetenciái között,BCE alumni és bejövő hallgatói kérdőív, 2013-14 (saját szerkesztés)

\begin{tabular}{|c|c|c|c|c|c|}
\hline $\begin{array}{l}\text { FELADATCSOPORT } \\
\text { MEGNEVEZÉSE }\end{array}$ & $\begin{array}{c}\text { GYAKORI } \\
\text { HASZNÁLAT } \\
\text { ÁTLAGA }\end{array}$ & $\begin{array}{c}\text { ALUMNI } \\
\text { KOMPETENCIA } \\
\text { SAJÁT } \\
\text { ÁTLAGTÓL }\end{array}$ & $\begin{array}{c}\text { BEJÖVÖ } \\
\text { KOMPETENCIA } \\
\text { SAJÁT } \\
\text { ÁTLAGTÓL }\end{array}$ & $\begin{array}{l}\text { MEAN } \\
\text { DIF. }\end{array}$ & SIG. \\
\hline Internethasználat & 1,964 & 0,478 & 0,858 & 0,377 & 0,000 \\
\hline $\begin{array}{l}\text { Táblázatkezelővel } \\
\text { táblázat készítése }\end{array}$ & 1,897 & 0,454 & 0,638 & 0,178 & 0,000 \\
\hline $\begin{array}{l}\text { Szövegszerkesztővel } \\
\text { egyszerű szöveg } \\
\text { készítése }\end{array}$ & 1,745 & 0,461 & 0,796 & 0,342 & 0,000 \\
\hline $\begin{array}{l}\text { Táblázatkezelővel } \\
\text { egyszerü képletek, } \\
\text { függvények } \\
\text { használata }\end{array}$ & 1,686 & 0,348 & 0,159 & $-0,185$ & 0,000 \\
\hline $\begin{array}{l}\text { Táblázatkezelővel } \\
\text { adatok elemzése }\end{array}$ & 1,486 & 0,252 & $-0,275$ & $-0,519$ & 0,000 \\
\hline $\begin{array}{l}\text { Táblázatkezelővel } \\
\text { haladó függvények }\end{array}$ & 1,362 & 0,127 & $-0,329$ & $-0,456$ & 0,000 \\
\hline Prezentációkészítés & 1,350 & 0,374 & 0,733 & 0,339 & 0,000 \\
\hline $\begin{array}{l}\text { Szövegszerkesztővel } \\
\text { hosszú dokumentum } \\
\text { készítése }\end{array}$ & 1,221 & 0,393 & 0,430 & 0,054 & 0,163 \\
\hline Adatbázis-kezelés & 0,786 & $-0,445$ & $-0,397$ & 0,051 & 0,416 \\
\hline $\begin{array}{l}\text { Táblázatkezelö } \\
\text { haladó használata }\end{array}$ & 0,785 & $-0,421$ & $-0,861$ & $-0,422$ & 0,000 \\
\hline $\begin{array}{l}\text { Szövegszerkesztővel } \\
\text { kiadvány készítése }\end{array}$ & 0,674 & 0,089 & 0,125 & 0,046 & 0,447 \\
\hline $\begin{array}{l}\text { Szövegszerkesztő } \\
\text { haladó használata }\end{array}$ & 0,667 & $-0,203$ & $-0,454$ & $-0,232$ & 0,000 \\
\hline $\begin{array}{l}\text { Multimédia } \\
\text { szerkesztés }\end{array}$ & 0,411 & $-0,608$ & $-0,067$ & 0,527 & 0,000 \\
\hline Programozás & 0,310 & $-0,969$ & $-0,903$ & 0,061 & 0,269 \\
\hline Webszerkesztés & 0,209 & $-1,009$ & $-0,415$ & 0,553 & 0,000 \\
\hline
\end{tabular}

A táblázatban a vastag vonal fölött látjuk azokat a feladatokat, amit a munkahelyen gyakran végeznek a dolgozók. A táblázatból leolvasható, hogy hogyan értékelik a saját kompetenciájukat ezekben a feladatokban és az is, hogy hogyan alakul az önértékelés a bejövő hallgatók körében. Azt láthatjuk, hogy mindkét csoportnál a vonal fölött zömében pozitív, 
míg a vonal alatt zömében negatív értékek vannak, azaz a gyakran végzett feladatokban kompetensebbek mind a dolgozók, mind az egyetemet kezdő hallgatók.

Ez alól két kivétel van. A táblázatkezelővel adatok elemzése és a táblázatkezelővel haladó függvények használata. Mindkettő gyakran végzett feladat a munkahelyen, ennek megfelelően a dolgozók kompetenciája meg is van hozzá, ám a hallgatóknál negatív értékeket látunk. Körvonalazódni látszik tehát, hogy ez az a két feladatcsoport, amiben a hallgatóknak a legnagyobb lemaradásuk van. 


\section{KÖVETKEZTETÉSEK ÉS TERVEK AZ ALAPOZÓ IN- FORMATIKA OKTATÁSRA VONATKOZÓAN}

A dolgozatban áttekintettem a mai pedagógiai gyakorlatot meghatározó elméleteket, Bloom taxonómiáját, a tanulási eredményeket, a kompetencia megközelítést. Felvázoltam az európai felsőoktatás átalakulását meghatározó bolognai folyamatot. Megvizsgáltam a gazdaságtani képzési terület (közgazdasági és üzleti szakok) képzési és kimeneti követelményeit Magyarországon és a világban, hangsúlyozva az informatikai kompetenciákat. Dokumentumelemzéssel megvizsgáltam a jelenlegi illetve a közelmúlt hazai gyakorlatát, kérdőívek segítségével és a jogi szabályozás áttekintésével képet kaptam a bejövő hallgatók informatikai kompetenciáiról. Interjúkat folytattam szaktanszéki és módszertani kollégákkal és további kérdőívekkel rákérdeztem végzett hallgatók tapasztalataira.

Az elemzésekből leszürt információ alapján a következő válaszokat tudom megfogalmazni az első fejezetben felsorolt kutatási alkérdésekre:

(A1) A képzési és kimeneti követelmények és az európai uniós iránymutatások alapján milyen informatikai kompetenciákra van szükség a gazdaságtani képzési területen, azon belül a közgazdasági és üzleti képzési szakokon?

\section{Közgazdasági (Economics) képzési szakok:}

Informatikai kompetenciák:

- a közgazdasági adatok értelmezése és kezelése (Lee Hansen):

○ értelmezni és használni kell tudni azokat a számszerű adatokat, amelyeket nyilvánosan publikált táblázatokban találnak,

○ fel kell tudni ismerni a mintázatokat és a trendeket az adatokban,

○ táblázatokat kell tudni létrehozni a fellelhető adatokból,

- releváns adatok és számszaki módszerek hatékony alkalmazása (Tuning)

- $\quad$ számszerüsítés és tervezés (Tuning):

○ az adatok hatékony elrendezése, prezentálása és elemzése,

○ adatok elsődleges forrásainak ismerete,

○ adatok informatív elrendezése és bemutatása,

○ a számszerü adatokat tudják strukturálni, elemezni és megmagyarázni,

○ számszerü információk használható formában történő kommunikálása, 
○ a nyersen nem értelmezhető adatok kritikus és egységes összefoglalójához szükséges prezentációs készségek,

- felmérések, jelentések készítésének képessége (KKK),

- döntés-előkészítés (KKK),

- gazdasági információs rendszerek ismerete (gazdaság- és pénzügy-matematikai elemzés, KKK).

További kompetenciák, melyek nem csak az informatikához kötődnek, de ott is megjelennek:

- elvonatkoztatás (absztrakció) (Tuning),

- elemzés, dedukció és indukció (Tuning, KKK),

- keretbe foglalás (Tuning),

- önállóság (KKK),

- kommunikációs készség (KKK),

- csoportmunka (KKK).

\section{Üzleti (Business) képzési szakok:}

Informatikai kompetenciák:

- információs rendszerek tervezése és kivitelezése (Tuning),

- a megfelelő szoftver azonosítása és használata (Tuning),

- felmérések, jelentések készítésének képessége (emberi erőforrások és kereskedelem és marketing, KKK),

- döntés-előkészítés (emberi erőforrások és gazdálkodási és menedzsment, KKK),

- informatikailag támogatott korszerü elemzési módszerek ismerete (emberi erőforrások, $\mathrm{KKK})$,

- prezentációs készség (KKK),

- korszerü informatikai eszközök használata (pénzügy és számvitel, KKK),

- a számviteli információs rendszer ismerete (pénzügy és számvitel, KKK),

- az emberierőforrás-gazdálkodás szervezeti és információs rendszerének működésének ismerete (emberi erőforrások, KKK).

További kompetenciák, melyek nem csak az informatikához kötődnek, de ott is megjelennek:

- önállóság (KKK), 
- kommunikációs készség (KKK),

- valamilyen elemzési képesség (KKK),

- $\quad$ csoportmunka (KKK).

A felsorolás szemmel láthatólag nem fedi a szükséges informatikai kompetenciák teljes körét jelenleg.

A szakmai törzsanyag keretében csak 2 szakon szerepel informatika. Emberi eröforrás szakon személyügyi informatika, pénzügy és számvitel szakon pedig pénzügyi és számviteli informatika.

A Tuning projektben a teljes felsőoktatásra megfogalmazott általános kompetenciák, melyek nem csak az informatikához kötődnek, de ott is megjelennek:

- problémamegoldás,

- elemzés és összefoglalás,

- a tudás gyakorlatban való alkalmazása,

- tanulási képesség,

- alkalmazkodás új helyzetekhez,

- önálló munkavégzés,

- minőség iránti elkötelezettség.

A közgazdasági és az üzleti szakok összehasonlításából látható, hogy az előbbiben részletesebb iránymutatást találunk az informatikai, vagy ahhoz szorosan kötődő kompetenciák területén, és ezek túlnyomó részt elemzéssel és az adatok feldolgozásával kapcsolatosak. Az üzleti szakokon valamivel hangsúlyosabban jelenik meg a prezentációs készség és a különböző információs rendszerek ismerete. A hatályos dokumentumokban megjelenő különbség nem fedi teljesen a valódi igényeket, hiszen a közgazdasági szakoknál megjelenő adatelemzési kompetenciák ugyanúgy szükségesek az üzleti szakokon is.

(A2) Milyen informatikai képzésben részesülnek jelenleg a gazdaságtani képzési terület hallgatói?

A jelenlegi hazai gyakorlatot a honlapokon fellelhető tantárgyi adatlapok és tantárgyleírások alapján tudtam áttekinteni. A hiányos információk miatt a kompetenciák közül a specifikusan informatikai, elsősorban tudás- és képességelemeket tudtam összehasonlítani. 
A magyar gyakorlatban jellemző, hogy az intézményeken belül nagyobb a hasonlóság, mint a szakok között. 2010-es adatok alapján átlagosan 2 kötelező informatika tárgy szerepelt az operatív tantervben. Gazdálkodás és menedzsment, illetve pénzügy és számvitel szakon (üzleti szakok) általában ennél több, közszolgálat szakon (közgazdasági szak) ennél kevesebb. A kötelező tárgyak kreditszáma 1 és 5 között változott.

17 intézmény kötelező informatika tárgyai között 8 alapozó informatika tantárgyra volt jellemző, hogy informatikai alapismereteket tartalmazott: hardver, operációs rendszer ismeretek. Gyakorlatban szövegszerkesztési, táblázatkezelési és prezentációkészítési alapismeretek szerepeltek. További két alapozó tárgyban az elméletben megjelent az adatvédelem, adatbiztonság, gyakorlatban haladóbb táblázatkezelési (adatelemzési) ismeretek jelentek meg. További 7 kötelező tárgyban szerepeltek vállalatirányítási illetve informatikai rendszerek. 2 kötelező tárgyban szerepeltek kifejezetten haladó táblázatkezelési, adatelemzési, modellezési ismeretek és 4-ben adatbázis-kezelés.

Emellett széleskörü, de intézményenként nagyon eltérő spektrumú a választható tárgyak köre, ezek között szerepelnek elemzö, informatikai rendszereket bemutató és webes tárgyak is.

2013-ban a BCE-n az üzleti szakokon egy kötelező és egy kötelezően választható informatika tárgy szerepelt (4 és 3 kredit), az ÁVF-en 2 kötelező tárgy 3-3 kreditért. Mindkét helyen elméleti alapismeretek mellett táblázatkezelés volt a gyakorlati anyag. A főiskolán emellett a gyakorlatokon volt még szövegszerkesztés, prezentáció és adatbázis-kezelés is. Az egyetemen pénzügyi és számvitel valamint emberi erőforrások szakon Excel programozás. Az egyetemen a kötelezően választható tárgy információs rendszerekről szólt. A szaktárgyak között az egyetemen gazdálkodás és menedzsment szakon szerepelt e-business, pénzügy és számvitel szakon pénzügyi és számviteli informatika, emberi erőforrások szakon pedig személyügyi informatika. A föiskolán a gazdálkodás és menedzsment szak egyes szakirányain szerepelt az adott szakiránynak megfelelő informatikai tárgy. Választható tárgyak mindkét intézményben vannak, az egyetemen szélesebb körben. 
2013-ban a közgazdasági szakokon a BCE-n 1 kötelező tárgy volt 4 kreditért, elméleti alapismeretek, gyakorlatban táblázatkezelés és Excel programozás, illetve gazdaságelemzés szakirányon Maple. Informatikai szaktárgyak ezeken a szakokon egyáltalán nem szerepelnek. Az ÁVF-en közszolgálat szakon 2 kötelező informatika tárgy van, ugyanúgy, mint az üzleti szakoknál. A választható tárgyak köre ugyanaz, mint az üzleti szakoknál, a gazdaságelemzés szaknak van még egy Excel programozást tartalmazó választható tárgya (náluk ez nem szerepelt a kötelező tananyagban).

\section{(A3) Milyen eltérések tapasztalhatók a képzési és kimeneti követelmények valamint az európai uniós iránymutatások és a jelenlegi hazai gyakorlat között?}

Az eltérések azonosítása csak részben valósulhat meg, mert a jelenlegi hazai gyakorlatról csak a tantárgyleírások álltak rendelkezésemre, amiből nem derült ki, hogy az egyéb kompetenciák megjelennek-e a tananyagban, és ha igen, hogyan.

Feltűnő eltérés, hogy mind a 2010-es, mind a 2013-as elemzésben markánsan jelen voltak az informatika elméleti alapjai, különböző hardver ismeretek, operációs rendszer, müszaki informatika, míg ezek a képzési és kimeneti követelményekben és az európai iránymutatásokban egyáltalán nem szerepelnek, legalábbis explicit módon nem. Bizonyos intézményeknél megjelentek gyakorlatban a szövegszerkesztési készségek is, melyek szintén nem szerepeltek explicit módon a másik oldalon.

Ezzel szemben a követelmények között - föleg a közgazdasági szakoknál - számos adatkezelési, elemzési kompetencia szerepelt, melyek az intézmények egy jelentős részében ( 8 kötelező alap tantárgy) teljesen hiányoztak az alapozó informatika tananyagból 2010-ben. (A helyzet azóta változhatott pozitív irányban.)

Mindkét szakcsoport követelményei között szerepelt a prezentálás, az adatok interpretálása, kommunikálása. A vizsgált tantárgyaknál a prezentáció csak elvétve és csak alap szinten jelent meg, az adatok kommunikálása explicit módon sehol.

Az információs rendszerek ismerete követelmény oldalon az üzleti szakok közül az emberi erőforrások és a pénzügy és számvitel szakon jelent meg, ennek megfelelően a tantárgyak elemzésénél is ezeken a szakokon találtam ilyen tartalmú szaktárgyakat. A Tuning projekt meghatározásában az üzleti területen megjelent még kompetenciaként az információs rendszerek tervezése és kivitelezése, ilyet 
explicit módon a tantárgyak elemzésénél nem találtam, de alapszakon szerintem ez nem is lehet elvárás, csak bizonyos mesterszakokon.

\section{(A4) Milyen kiinduló ismeretekre és képességekre támaszkodhatunk a képzés során?}

A jogszabályok áttekintése és az empirikus kutatásom alapján megállapítottam, hogy kimutathatóan szélesebb körü informatikai kompetenciával érkeznek a hallgatók a felsőoktatásba, mint akár néhány évvel korábban, és valószínüleg érdemes továbbra is figyelemmel kísérni ezt a változást, hogy szükség esetén a felsőoktatás erre reagálni tudjon. A kutatássorozat folytatása során érdekes lesz annak vizsgálata is, hogy az új technológiák kezelése milyen ütemben kerül be a hallgatók kompetenciái közé.

Mind a jogszabályok, mind az önbevalláson alapuló kérdőívek azt mutatják, hogy az internethasználati, szövegszerkesztési, táblázatkezelési és prezentációs alapismereteket, alapképességeket már az egyetem előtt megszerzik a hallgatók. Vannak területek, ahol viszont az önbevallott tudás elmarad a törvényben elöírtaktól. Tipikusan ilyen terület az adatbázis-kezelés, a webszerkesztés és az adatelemzés.

\section{(A5) Milyen informatikai kulcskompetenciákra van szüksége a munkába lépö diplomá- soknak a gazdaságtani képzési területen, az üzleti és közgazdasági szakokon?}

A kérdés megválaszolásához a 4. mellékletben található gazdaságinformatikai ontológia alapján meghatározott kompetenciák és az ECDL vizsgakövetelmények által meghatározott és azon túlmutató felhasználói ismeretek és képességek unióját kell leszükíteni oly módon, hogy csak a gazdaságtan szempontjából releváns kompetenciák maradjanak. A szükítésben felhasználhatjuk az előző alkérdésekre adott válaszokat. A kompetenciakörből a szakkompetenciákat kell még kivennünk, hogy a szükséges kulcskompetenciák maradjanak. A kompetenciák meghatározásakor nem szabad megfeledkeznünk arról, hogy a technológia és az elvárások folyamatosan változnak, tehát egyrészt szükséges a változásokhoz való alkalmazkodás kompetenciája is, másrészt a most leírt pontokat néhány évente szükségszerüen felül kell bírálni.

- A számítástechnikai architektúra elemei közül a kommunikáció eszközeinek ismerete és alkalmazása (internetes és mobil),

- Az információ architektúra elemei közül: 
○ A tranzakció-feldolgozás lépéseinek végrehajtása: adattárolás, adatbevitel, adatgyüjtés, primér feldolgozás, eredmények megjelenítése, dokumentum-archiválás,

○ MIS (Management Information System) ismerete és alkalmazása, riportkészítés, automatizálható megoldások - szakkompetencia,

○ Döntéstámogatás - szakkompetencia,

○ Csoportmunka alkalmazások ismerete és használata,

○ Workflow alkalmazások ismerete és használata - szakkompetencia,

○ Felsővezetői információszolgáltatás alkalmazása - szakkompetencia,

- Alkalmazási területek elemei közül:

○ Integrált vállalatirányítási rendszerek ismerete és használata - szakkompetencia,

- A gazdaságinformatikai és felhasználói kompetenciák metszetében található a kommunikáció és a különböző táblázatkezelővel és adatbázis-kezelővel megoldható feladatok megoldásának képessége:

○ Internetes és mobil kommunikáció,

○ Táblázatkezelővel táblázat készítése,

○ Táblázatkezelővel egyszerü képletek-függvények használata,

○ Táblázatkezelővel haladó függvények használata,

○ Táblázatkezelővel adatok elemzése,

○ Táblázatkezelővel makró készítése (táblázatkezelő haladó használata),

○ Adatbázis-kezelés - szakkompetencia,

- További szükséges kompetenciák:

○ Szövegszerkesztővel egyszerü dokumentumok készítése,

○ Szövegszerkesztővel hosszú dokumentumok készítése,

○ Prezentációs készségek,

○ Önállóság,

○ Problémamegoldás,

- Alkalmazkodás új helyzetekhez,

○ Minőség iránti elkötelezettség. 
A felsorolásban jelzett szakkompetenciák egy része beépül az egyes szakokon megjelenő szaktárgyakba, más részük választható tárgyak keretében sajátítható el. Emellett a kompetenciák egy részét, a leginkább munkahely-specifikus tudást a dolgozók már a munkahelyükön fogják megszerezni.

(A6) Melyik területeken van eltérés a munkahelyen szükséges és a már az egyetemre lépéskor meglévö informatikai kulcskompetenciák között?

Ahogy az az A4-re adott válaszból kiolvasható, az előző pontban felsorolt nem szakkompetenciák egy része már a felsőoktatásba lépő hallgatóknál is megvan, mint pl. az internethasználat, vagy a szövegszerkesztő és táblázatkezelö programok használatának alapjai. Az információs társadalom fejlödésével a hozott kompetenciák köre is folyamatosan változik, így nem csak az A5 kérdésre adott választ, hanem annak szükítését is felül kell vizsgálni időről időre. A jelenlegi állapot szerint a szükséges kulcskompetenciák közül az alábbiak nincsenek még meg a bejövő hallgatóknál:

1. Csoportmunka alkalmazások ismerete és használata,

2. Táblázatkezelővel haladó függvények használata,

3. Táblázatkezelővel adatok elemzése,

4. Táblázatkezelővel makró készítése (táblázatkezelő haladó használata),

5. Eredmények megjelenítése, vizualizáció,

6. Önállóság,

7. Problémamegoldás,

8. Alkalmazkodás új helyzetekhez,

9. Minőség iránti elkötelezettség.

(K1) Mi legyen a célja és a tartalma az informatika alapozó kurzusoknak a gazdaságtudományok képzési terület szakjain?

Az alkérdésekre adott válaszok alapján már meg lehet válaszolni a fő kérdést. Az alapozó informatika kurzusok célja, hogy a bejövő tudásra építve olyan informatikai és tantárgyközi kulcskompetenciákat fejlesszen ki a hallgatókban, melyek segítségével a dinamikusan változó munka világában is megállják a helyüket, illetve amelyekre építve a további tanulmányaik során az informatikai szakkompetenciákat is el tudják sajátítani.

Ahhoz, hogy a későbbi szakkompetenciákat hatékonyan tudják elsajátítani, szükséges az alapok stabil letétele. Egy táblázatkezelő program szakértő használatának elsajátítása szolgálhatja ezt a célt. A vizsgált gazdaságtani szakterületen a problémák jelentős része eleve megoldható táblázatkezelő eszközök segítségével. A kutatások azt mutatták, hogy 
a vállalati környezetben is ezekkel az alkalmazásokkal találkoznak leginkább a munkavállalók (2., 3., 4. és 5. kompetencia az A6 kérdésre adott felsorolásban). Ezen túl a specifikus programok használatának elsajátításában is jelentős segítség, ha az adatkezelés, adatelemzés alapjait egy ismert programkörnyezetben már elsajátították.

A tananyagot a problémamegoldás elvén kell felépíteni. Ezzel az A6 pontban felsorolt kompetenciák közül a problémamegoldást, az önállóságot is lehet fejleszteni (6. és 7.). A probléma felőli megközelítés lehetőséget teremt arra is, hogy a megfelelő kapcsolódási pontokat kiépítsük a később elsajátítandó szakkompetenciák felé és ezzel elősegítsük az új helyzetekhez való alkalmazkodás képességének kialakulását (9.).

A problémamegoldás egymásra épülő fokozatait a komplexitás szintjének növekedésével arányosan lehet szakaszolni. A komplexitás a tárgyalt esetben az adatféleségek körével és az adatfeldolgozás bonyolultsági szintjével írható le. A vizsgált téma szempontjából a következő szintek határozhatók meg:

1. adatok statikus kezelése: táblázatba foglalás, egyszerü számítások,

2. adatok dinamikus kezelése, jellemzően táblázatkezelő alkalmazással vagy azzal is megoldható problémák: képletek használata, vizualizáció,

3. adatbázisok integrált kezelése,

4. problémamegoldás, az ehhez megfelelő különböző alkalmazások megtalálása és integrált kezelése.

A technológia fejlődését az oktatás értelemszerüen soha nem tudja időben integrálni, hiszen hiába tanítjuk adott esetben az aktuálisan legújabb technológiát, mire az elsőéves hallgató diplomát szerez és munkába áll, a technológia tovább fejlődik. Ennek ellenére törekedni kell a fejlődési tendenciák legalább ismeret szintű megtanítására és fel kell vázolni azokat az irányokat, amelyekbe a hallgatók a saját szakjuk kapcsán továbbléphetnek. Ezt a törekvést segíti, ha ebben a körben relatíve stabilabb elemekre építjük a konkrét oktatási anyagokat.

Az A6 kérdésre adott válaszban felsorolt további két kompetencia, a csoportmunka és a minőség iránti elkötelezettség elsajátítását módszertani eszközökkel lehet elősegíteni.

A kutatási eredmények validálásához szükséges az elméletileg igazolt megállapítások gyakorlati implementációja. Ennek egy lehetséges formája egy korszerü, a bolognai folyamatnak, a képzési és kimeneti követelményeknek és a munkahelyi elvárásoknak megfelelö, a peremfeltételeket figyelembe vevö tananyag összeállítása. 
Deklaratív tudás (ismeret és megértés szintjén): informatikai alapfogalmak definíciója, jellemzői, típusai (információ, adat), az informatika aktuális és jövőbeli trendjei, a gazdaság és a közszféra informatikai rendszerei, kommunikációs eszközök, hálózatok, adatbiztonság

Képességek (a kognitív tartomány alkalmazás szintjén):

Információ értékelése az információ jellemzői alapján. Adattípusok felismerése és a müveleteknek megfelelő adattípusok használata.

Táblázatkezelő és prezentációkészítő alkalmazások meghatározott eszközeinek hozzáértő használata. Az itt felsorolt eszközök egy részének alapszintü használatának képessége már a hallgatók nagy részének az egyetemre lépéskor megvan, a kurzus eredménye optimális esetben a szakértő használaton túl a problémából kiindulva a megoldáshoz szükséges munkafolyamatok megtervezésének képessége is lesz. Tanulási eredményként (minimum követelmény) a hozzáértő használatot lehet elöírni.

A generikus kompetenciák közül a problémamegoldást szem előtt tartva a 34. táblázatban felvázolt konkrét esettanulmány mentén a folyamatosan felmerülő újabb problématípusok megoldására nyújtsunk megfelelő eszközkészletet. Ezek az eszközök alkalmazásfüggetlenek, amellett, hogy az esettanulmány végigvitele során természetesen egy konkrét programcsomag használata elengedhetetlen. (Ez többnyire még a Microsoft Office programcsomag valamelyik verziója, de a hallgatók figyelmét is fel kell hívni az alternatív lehetőségekre, open-source megoldásokra.)

34. táblázat Megrendelések kezeléséről szóló komplex esettanulmány során felmerülő problémák és a megoldásukhoz szükséges eszközkészlet (A probléma leírásánál zárójelben a problémaszinteket jeleztem)

\begin{tabular}{|l|l|l|}
\hline \multicolumn{1}{|c|}{ PROBLÉMA LEÍRÁSA } & \multicolumn{1}{|c|}{ KONKRÉT FELADAT } & \multicolumn{1}{c|}{ ESZKÖzÖK } \\
\hline $\begin{array}{l}\text { Megrendelés ellenértékének } \\
\text { kiszámolása költségekböl } \\
\text { levezetve (1. szint) }\end{array}$ & $\begin{array}{l}\text { Számolások meghatározott } \\
\text { értékekkel }\end{array}$ & $\begin{array}{l}\text { Egyszerü képletek, } \\
\text { függvények, abszolút- } \\
\text { relatív hivatkozás }\end{array}$ \\
\hline $\begin{array}{l}\text { Különbözö formátumokban } \\
\text { kapott megrendelőlapok } \\
\text { alapján az ellenérték } \\
\text { kiszámolása (1. szint) }\end{array}$ & $\begin{array}{l}\text { Adatok áthelyezése a } \\
\text { táblázatkezelőbe, átalakítás, } \\
\text { hogy a számolásokat végre } \\
\text { lehessen hajtani }\end{array}$ & $\begin{array}{l}\text { Importálás, szöveg és } \\
\text { dátumkezelő eszközök }\end{array}$ \\
\hline $\begin{array}{l}\text { Az árajánlatot devizában } \\
\text { kérik (2. szint) }\end{array}$ & $\begin{array}{l}\text { Aktuális árfolyam } \\
\text { beillesztése pl. az } \\
\text { arfolyam.hu-ról }\end{array}$ & $\begin{array}{l}\text { Importálás honlapról, } \\
\text { frissítés, szövegkezelő } \\
\text { eszközök }\end{array}$ \\
\hline $\begin{array}{l}\text { A megrendelésben döntési } \\
\text { változók is szerepelnek, pl. }\end{array}$ & $\begin{array}{l}\text { A döntési folyamat } \\
\text { formalizálása }\end{array}$ & Feltételes függvények (If) \\
\hline
\end{tabular}


DOI: $10.14267 /$ phd.2014081

\begin{tabular}{|c|c|c|}
\hline PROBLÉMA LEÍRÁSA & KONKRÉT FELADAT & EsZKÖZÖK \\
\hline $\begin{array}{l}\text { mennyiségi kedvezmény } \\
\text { (2. szint) }\end{array}$ & & \\
\hline $\begin{array}{l}\text { A megrendelés } \\
\text { teljesítéséhez az adatokat } \\
\text { valamilyen szempontok } \\
\text { szerint összegezni kell } \\
\text { (2. szint) }\end{array}$ & Feltételek megfogalmazása & $\begin{array}{l}\text { Feltételes összesítő } \\
\text { függvények (darabteli, } \\
\text { szumha, countif, sumif) }\end{array}$ \\
\hline $\begin{array}{l}\text { A megrendelésekkel } \\
\text { kapcsolatban, vagy az } \\
\text { egyéb adatainkkal } \\
\text { kapcsolatban különböző ad- } \\
\text { hoc vezetöi kérdésekre } \\
\text { választ kell adnunk. Pl. } \\
\text { Van-e raktáron bizonyos } \\
\text { termék, mely } \\
\text { terméktípusokból rendeltek } \\
\text { a legtöbbet, stb. (2. szint) }\end{array}$ & $\begin{array}{l}\text { A táblázat sorainak } \\
\text { megfelelő részhalmazának } \\
\text { megjelenítése, adatok gyors } \\
\text { átláthatóvá tétele }\end{array}$ & $\begin{array}{l}\text { Szürés, rendezés, feltételes } \\
\text { formázás }\end{array}$ \\
\hline $\begin{array}{l}\text { A megrendelésben csak a } \\
\text { terméknevek vagy kódok és } \\
\text { a mennyiségek szerepelnek, } \\
\text { az egyéb jellemzők } \\
\text { (egységár, van-e raktáron, } \\
\text { stb.) nem (2. szint) }\end{array}$ & $\begin{array}{l}\text { Saját adattábláinkból ki kell } \\
\text { keresni a megfelelö } \\
\text { adatokat }\end{array}$ & $\begin{array}{l}\text { Keresési függvények } \\
\text { (Lookup) }\end{array}$ \\
\hline $\begin{array}{l}\text { Jelentéseket kell } \\
\text { készítenünk a felsőbb } \\
\text { vezetői döntések } \\
\text { előkészítésére ( } 2 . \text { szint) }\end{array}$ & $\begin{array}{l}\text { Megrendelések adatait } \\
\text { táblázatba rendezni, } \\
\text { különböző adattábláinkból } \\
\text { (raktárkészlet, költségtábla, } \\
\text { megrendelések) összesítő, } \\
\text { kibontható táblázatokat } \\
\text { készíteni }\end{array}$ & Kimutatás (pivot table) \\
\hline $\begin{array}{l}\text { Adatainkat be kell } \\
\text { mutatnunk cégen belül vagy } \\
\text { kívül. ( } 2 \text {. szint) }\end{array}$ & $\begin{array}{l}\text { Vizualizáció. Diagramok, } \\
\text { grafikonok készítése, } \\
\text { prezentálása }\end{array}$ & $\begin{array}{l}\text { Diagram (Chart), diagram } \\
\text { animálása prezentációban }\end{array}$ \\
\hline $\begin{array}{l}\text { Gyakran ismétlődő feladat, } \\
\text { pl. a megrendelést mindig } \\
\text { azonos, de feldolgozásra } \\
\text { alkalmatlan formában } \\
\text { kapjuk. (2. szint) }\end{array}$ & $\begin{array}{l}\text { Elvégzett müveletek } \\
\text { automatizálása. }\end{array}$ & $\begin{array}{l}\text { Makró rögzítés, módosítás, } \\
\text { futtatás }\end{array}$ \\
\hline $\begin{array}{l}\text { Ne legyen szükség a } \\
\text { megrendelőlap állandó } \\
\text { átalakítására ( } 2 \text {. szint) }\end{array}$ & $\begin{array}{l}\text { Automatikusan } \\
\text { feldolgozható űrlap } \\
\text { készítése }\end{array}$ & Ürlap eszközök (form) \\
\hline
\end{tabular}


DOI: $10.14267 /$ phd.2014081

\begin{tabular}{|l|l|l|}
\hline \multicolumn{1}{|c|}{ PROBLÉMA LEÍRÁSA } & \multicolumn{1}{c|}{ KONKRÉT FELADAT } & \multicolumn{1}{c|}{ ESZKÖzÖK } \\
\hline $\begin{array}{l}\text { Az árazási modell } \\
\text { kialakításához nekünk kell } \\
\text { számításokkal } \\
\text { alátámasztani a különbözö } \\
\text { alternatívákat (2. szint) }\end{array}$ & $\begin{array}{l}\text { Adattáblák, érzékenységi } \\
\text { vizsgálatok }\end{array}$ & Adattábla \\
\hline $\begin{array}{l}\text { A beérkezett } \\
\text { megrendelések kiszállítását } \\
\text { a különböző raktárainkból } \\
\text { szeretnénk optimalizálni } \\
\text { (2. szint) }\end{array}$ & Szállítási feladat megoldása & Optimalizáló eszköz, Solver \\
\hline $\begin{array}{l}\text { Az árazási modellt is } \\
\text { nekünk kell kialakítani } \\
\text { (2. szint) }\end{array}$ & $\begin{array}{l}\text { Matematikai modellek } \\
\text { algoritmizálása }\end{array}$ & Makró írás \\
\hline
\end{tabular}

Az esettanulmányban szereplő problémák az első két problémaosztályhoz tartoznak. Az alapozó informatika képzésben a magasabb szintek elérése nem követelmény egyelőre, de az esettanulmány lehetőséget nyújt arra is, hogy egyes problémák kapcsán bemutassuk a táblázatkezelő programok által nyújtott lehetőségeken túli megoldásokat. Ezek részletes bemutatására egy ilyen alapozó kurzus kevés, de mindenképpen fontosnak tartom a kapcsolódási pontok kiépítését.

A kognitív tartomány magasabb szintjei (elemez, értékel, alkot): nem szükségesek.

Attitüd: az explicit tananyagleírásban kevésbé, inkább a módszertan segítségével elérhető tanulási eredmények. Alkalmazkodás új helyzetekhez, problémamegoldás, önállóság, minőség iránti elhivatottság.

A teljes tananyag problémaorientált megközelítése biztosíthatja a bevezetőben felvázolt ellentét feloldását a dinamikusan változó munka világa és a statikus képzési és kimeneti követelmények között (1. ábra). 
DOI: $10.14267 /$ phd.2014081 
DOI: 10.14267/phd.2014081

\section{FÜGGELÉK}


DOI: 10.14267/phd.2014081 


\section{1. melléklet A dolgozatban használt kompetencia fogalom struktúrája}

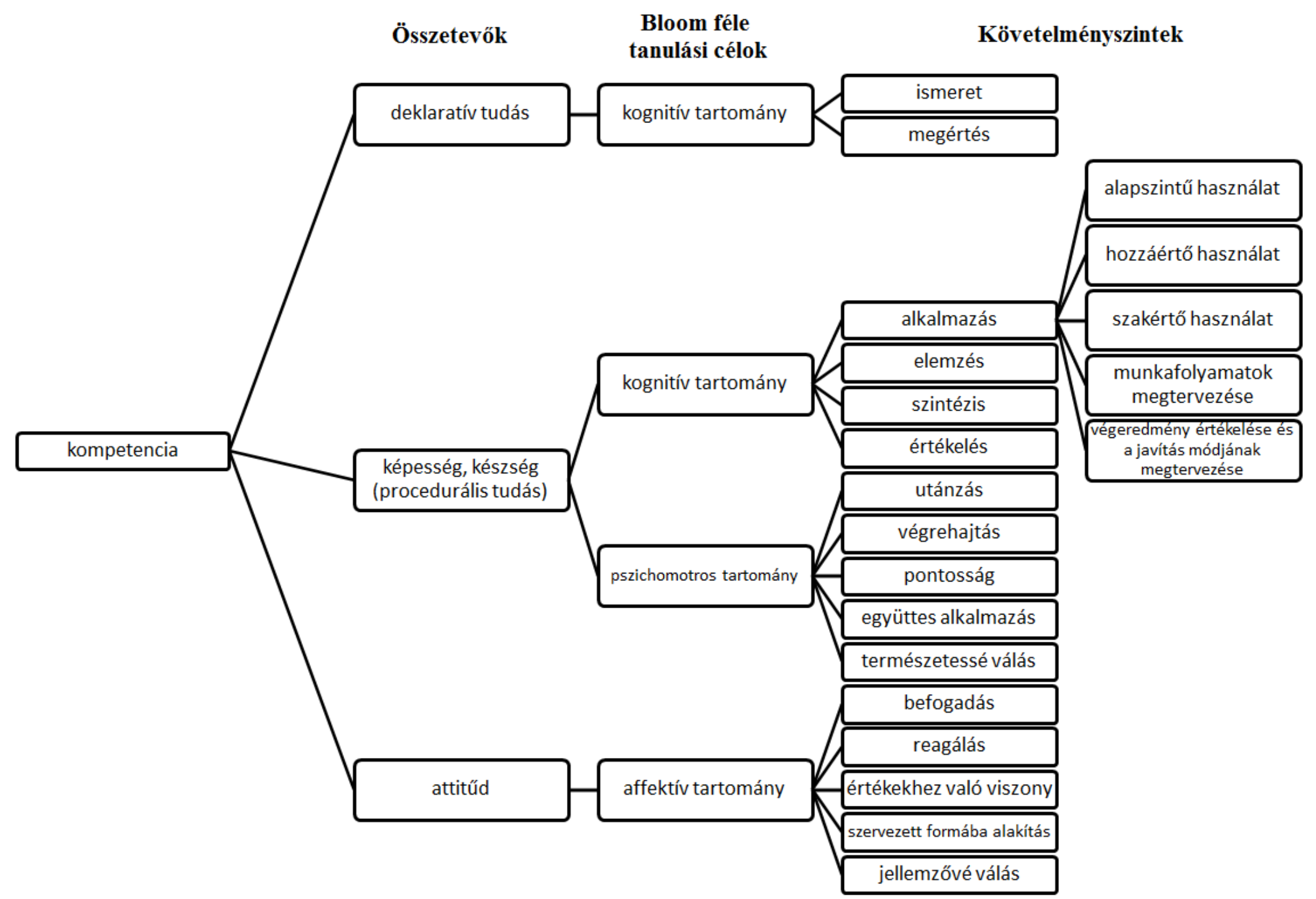




\section{2. melléklet A magyar képesítési keretrendszer szintjei [Kormány határozat, 2012]}

\begin{tabular}{|c|c|c|c|c|}
\hline Szint & Tudás & Képességek & Attitüdök & Autonómia és felelősség \\
\hline 1 & $\begin{array}{l}\text { - Ismeri egy adott témakör alapvető tényeit, leg- } \\
\text { fontosabb fogalmait. } \\
\text { - Rendelkezik az alapvető anyanyelvi, logikai } \\
\text { és eszköztudással. } \\
\text { - Ismeri a gyakorlati tevékenységhez szükséges } \\
\text { jellemző anyagokat és eszközöket. } \\
\text { - Érti és betartja a feladat/múveletvégzés eljárá- } \\
\text { sait, végrehajtási szabályait. }\end{array}$ & $\begin{array}{l}\text { - A kulcskompetenciák (kiemelten: anyanyelvi, } \\
\text { matematikai-logikai) alapszintü fejletsége jel- } \\
\text { lemzi. } \\
\text { - Képes a feladatvégzés/problémamegoldás so- } \\
\text { rán szükséges tudás alkalmazására, amennyiben } \\
\text { az egyszerü, begyakorolt rutinok, algoritmusok } \\
\text { használatát igényli. }\end{array}$ & $\begin{array}{l}\text { - Nyitott a feladatok megérté- } \\
\text { sére, motivált azok sikeres vég- } \\
\text { rehajtásában. } \\
\text { - Kíváncsi és érdeklődő tanulási } \\
\text { és elemi munkavégzési helyze- } \\
\text { tekben. } \\
\text { - Kész a közös munkára, tudásá- } \\
\text { nak másokkal való megosztására. }\end{array}$ & $\begin{array}{l}\text { - Egyszerübb, begyakorolt fel- } \\
\text { adathelyzetekben képes az ön- } \\
\text { álló feladatvégzésre. } \\
\text { - Újszerü vagy összetettebb } \\
\text { feladat esetén irányításra és fo- } \\
\text { lyamatos ellenörzésre van szük- } \\
\text { sége. } \\
\text { - Irányítással értékelni tudja sa- } \\
\text { ját munkáját. }\end{array}$ \\
\hline 2 & $\begin{array}{l}\text { - Ismeri adott témakör (müveltségterület, szak- } \\
\text { terület) alapvető tényeit, fogalmait, egyszerübb } \\
\text { összefüggéseit. } \\
\text { - Rendelkezik általános anyanyelvi, matemati- } \\
\text { kai-logikai és természettudományos eszköztu- } \\
\text { dással. Rendelkezik egy adott szakma alapfokú- } \\
\text { középszintü gyakorlásához szükséges elméleti } \\
\text { és gyakorlati ismeretekkel. }\end{array}$ & $\begin{array}{l}\text { - Képes egyszerübb ok-okozati összefüggések } \\
\text { felismerésére. } \\
\text { - Képes különböző témákkal összefüggésben } \\
\text { azonosítás, megkülönböztetés, összehasonlítás } \\
\text { elvégzésére megadott szempontok mentén. } \\
\text { - Képes esetenként több összetevőböl álló fel- } \\
\text { adatok/múveletsorok elvégzésére. } \\
\text { - Képes alapvető eszközök és anyagok haszná- } \\
\text { latára útmutatással. } \\
\text { - Képes a témának megfelelő írásbeli és szóbeli } \\
\text { közlés létrehozására, az arra való reagálásra, az } \\
\text { egyszerủ szaknyelv használatára. } \\
\text { - Rendelkezik az együttmüködéshez szükséges } \\
\text { alapvető kompetenciákkal. }\end{array}$ & $\begin{array}{l}\text { - Tanulási helyzetekben, felada- } \\
\text { tokban nyitott a tudását növelö } \\
\text { tevékenységekre. } \\
\text { - Tisztában van az alapvető er- } \\
\text { kölcsi és közösségi értékekkel, } \\
\text { az alapvetó állampolgári jogok- } \\
\text { kal és kötelességekkel. }\end{array}$ & $\begin{array}{l}\text { - Egyszerü feladathelyzetekben } \\
\text { önállóan és felelősséggel dol- } \\
\text { gozik. } \\
\text { - Összetettebb feladatok esetén } \\
\text { is elégséges az útmutatás a szo- } \\
\text { ros irányítás helyett. } \\
\text { - Kialakul a felelősségtudat, és } \\
\text { megjelenik az önkontroll az el- } \\
\text { végzett munka értékelésében. }\end{array}$ \\
\hline
\end{tabular}




\begin{tabular}{|c|c|c|c|c|}
\hline Szint & Tudás & Képességek & Attitüdök & Autonómia és felelősség \\
\hline 3 & $\begin{array}{l}\text { - Ismeri az adott tanulmányi, müveltség- vagy } \\
\text { szakterülethez tartozó alapvető tényeket, fogal- } \\
\text { makat, folyamatokat, felismeri és érti a többté- } \\
\text { nyezős összefüggéseket. } \\
\text { - A feladatmegoldáshoz/munkavégzéshez szük- } \\
\text { séges eszközök, módszerek és eljárások isme- } \\
\text { rete mellet alkalmazza a megismerés, az önálló } \\
\text { ismeretszerzés alapvető módszereit. } \\
\text { - Az egyéni érdeklődésnek megfelelő művelt- } \\
\text { ség-/ szakterületen szélesebb körü tudáselemek- } \\
\text { kel rendelkezik. } \\
\text { - Ismeri és alkalmazza a feladatvégzés eljárá- } \\
\text { sait, szabályait. }\end{array}$ & $\begin{array}{l}\text { - Képes ismeretek, tudássémák összekapcsolá- } \\
\text { sára, új sémák kialakítására ismert kontextus- } \\
\text { ban. } \\
\text { - Képes az egyszerúbb feladatok rutinszerű el- } \\
\text { végzése mellett új, szokatlan elemeket is tartal- } \\
\text { mazó problémák kreatív megoldására. } \\
\text { - Képes a megfelelő eszközök, anyagok kivá- } \\
\text { lasztására és használatára. } \\
\text { - Képes összefüggésekben, rendszerben gondol- } \\
\text { kodni. }\end{array}$ & \begin{tabular}{|l|} 
- Képes kritikusan is szemlélni \\
és használni a különböző forrá- \\
sokból származó információkat. \\
- Nyitott az együttes erőfeszí- \\
tésre, közös munkára, elfogadja a \\
kölcsönös függési helyzetet. \\
- Magára nézve is érvényesnek \\
tartja az általánosan elfogadott \\
társadalmi normákat a minden- \\
napi és a szakmai érintkezésben \\
egyaránt. \\
- Az érdeklödésének megfelelő \\
szakterület, a végzett szakma \\
iránt elkötelezett.
\end{tabular} & $\begin{array}{l}\text { - Általánossá válik az önkont- } \\
\text { roll és a rendszeres reflexió a } \\
\text { saját tanulási és munkatevé- } \\
\text { kenységre. }\end{array}$ \\
\hline 4 & $\begin{array}{l}\text { - Adott müveltség- és szakterületen belül ismeri } \\
\text { a tényeket, fogalmakat, megérti a fontosabb fo- } \\
\text { lyamatokat és összefüggéseket. } \\
\text { - Ismeri a szakmai nyelvezetet, a szakterület } \\
\text { terminológiáját, lehetőleg idegen nyelven is. } \\
\text { - Ismeri és érti az adott, egyéni érdeklődésnek } \\
\text { megfelelö müveltség-/szakterület tudáselemei- } \\
\text { nek összefüggéseit, struktúráját. } \\
\text { - Megérti a bonyolult, többtényezős jelenségek } \\
\text { összefüggésrendszerét. } \\
\text { - Rendelkezik az adott tudásterületek tényeinek, } \\
\text { fogalmainak, összefüggéseinek, eljárásainak al- } \\
\text { kalmazásához szükséges módszerekkel és esz- } \\
\text { köztudással. }\end{array}$ & $\begin{array}{l}\text { - Képes adott témakörhöz, szakterülethez tar- } \\
\text { tozó tudás alkalmazására nem megszokott kon- } \\
\text { textusban. } \\
\text { - Képes rendszerben gondolkodni, az absztrak- } \\
\text { ció bizonyos formáit alkalmazni. } \\
\text { - Képes új információk önálló megszerzésére és } \\
\text { feldolgozására. } \\
\text { - Képes saját tanulási, problémamegoldó straté- } \\
\text { gia megtervezésére és kivitelezésére, a megfe- } \\
\text { lelö korrekciók elvégzésére. } \\
\text { - Képes a szak-/tanulmányi területen megjelenő } \\
\text { problémahelyzetek felismerésére, adekvát meg- } \\
\text { oldási javaslatok megfogalmazására. }\end{array}$ & \begin{tabular}{|l|} 
Nyitott új feladatok végzésére. \\
- Értékelni tud lehetőségeket, \\
mérlegelni tud kockázatokat, al- \\
ternatívákat és következménye- \\
ket, képes kompromisszumos \\
megoldásokra. \\
- Döntési helyzetekben az etikai \\
és jogi normák figyelembevétele, \\
az értékek, viselkedés és életmód \\
összefüggéseinek megértése jel- \\
lemzi. \\
- A szakma és a minőségi mun- \\
kavégzés iránt elkötelezett. \\
- Igényli a folyamatos önkép- \\
zést, alkalmazza annak eljárásait.
\end{tabular} & $\begin{array}{l}\text { - Az önállóság és az önkontroll } \\
\text { a munkavégzésben, probléma- } \\
\text { megoldásban és tanulásban } \\
\text { egyaránt jellemző. } \\
\text { - Felelösséget vállal saját tevé- } \\
\text { kenységéért, a rábízott kisebb } \\
\text { csoport, közösség munkájáért. } \\
\end{array}$ \\
\hline
\end{tabular}




\begin{tabular}{|c|c|c|c|c|}
\hline Szint & Tudás & Képességek & Attitüdök & Autonómia és felelősség \\
\hline 5 & $\begin{array}{l}\text { - Rendelkezik egy adott szakterülethez kapcso- } \\
\text { lódó alapvető általános és szakspecifikus elmé- } \\
\text { leti és gyakorlati ismeretekkel. Az elméleti és } \\
\text { gyakorlati tudása rendszerbe szerveződik. } \\
\text { - A gyakorlati alkalmazás módszereinek és esz- } \\
\text { közeinek biztos ismerete lehetőséget biztosít az } \\
\text { adott szakma hosszú távú és magas szintú gya- } \\
\text { korlására. } \\
\text { - Ismeri a szakterület szakmai szókincsét (anya- } \\
\text { nyelven és legalább egy idegen nyelven). }\end{array}$ & $\begin{array}{l}\text { - Képes az adott szakma feladatainak megoldá- } \\
\text { sára: megtervezésére és lebonyolítására, a szük- } \\
\text { séges módszerek és eszközök kiválasztására, } \\
\text { egyedi és komplex alkalmazására. } \\
\text { - Anyanyelvi és idegen nyelvi kommunikációs } \\
\text { képességei képessé teszik a más nyelven beszé- } \\
\text { lökkel való szakmai együttmüködésre. } \\
\text { - Képes tudását fejleszteni és ehhez alkalmazni } \\
\text { a tudásszerzés, önfejlesztés különbözö módsze- } \\
\text { reit és a legkorszerübb információs és kommu- } \\
\text { nikációs eszközöket. } \\
\text { - Képes a munkavállalással, vállalkozással kap- } \\
\text { csolatos felelős döntésekre. }\end{array}$ & $\begin{array}{l}\text { - Nyitott az adott szakterület új } \\
\text { eredményei, innovációi iránt. } \\
\text { Törekszik azok megismerésére, } \\
\text { megértésére és alkalmazására. } \\
\text { - Törekszik önmaga folyamatos } \\
\text { képzésére. } \\
\text { - Elkötelezett a minőségi szak- } \\
\text { mai munkavégzés mellett. } \\
\text { - Önkritikus saját munkájával } \\
\text { szemben. } \\
\text { - Elfogadja és hitelesen közvetíti } \\
\text { szakmája társadalmi szerepét, ér- } \\
\text { tékeit. }\end{array}$ & $\begin{array}{l}\text { - Önállóan végzi munkáját, fo- } \\
\text { lyamatos önellenőrzés mellett. } \\
\text { - Felelösséget érez saját és az } \\
\text { általa vezetett szakmai csoport } \\
\text { munkájáért, eredményeiért és } \\
\text { kudarcaiért. } \\
\text { - Döntéseit a szakterület jogi, } \\
\text { etikai szabályainak figyelembe- } \\
\text { vételével hozza. } \\
\text { i }\end{array}$ \\
\hline 6 & $\begin{array}{l}\text { - Ismeri egy adott tanulmányi és/vagy szakterü- } \\
\text { let tárgykörének alapvető, átfogó tényeit, irá- } \\
\text { nyait és határait. } \\
\text { - Ismeri az adott szak, illetve tanulmányi terület } \\
\text { legfontosabb összefüggéseit, elméleteit és az } \\
\text { ezeket felépítö terminológiát. } \\
\text { - Ismeri szakterületének alapvető ismeretszer- } \\
\text { zési és probléma-megoldási módszereit. }\end{array}$ & $\begin{array}{l}\text { - Képes az adott szakterület ismeretrendszerét } \\
\text { alkotó elképzelések alapfokú analízisére, az ösz- } \\
\text { szefüggések szintetikus megfogalmazására és } \\
\text { adekvát értékelö tevékenységre. } \\
\text { - Rendelkezik az önálló tanuláshoz szükséges } \\
\text { képességekkel. } \\
\text { - Képes rutin szakmai problémák azonosítására, } \\
\text { az azok megoldásához szükséges elvi és gyakor- } \\
\text { lati háttér feltárására, megfogalmazására és } \\
\text { (standard műveletek gyakorlati alkalmazásával) } \\
\text { megoldására. } \\
\text { - Képes használni, megérteni szakterületének } \\
\text { jellemző szakirodalmát, számítástechnikai, } \\
\text { könyvtári forrásait. } \\
\text { - Képes a másokkal való kooperációra. } \\
\text { - Képes a különféle erőforrásokkal gazdálkodni. } \\
\text { - Képes adott munkahely különböző szakmai } \\
\text { elvárásainak megfelelően felhasználni szakmai } \\
\text { tudását. }\end{array}$ & $\begin{array}{l}\text { - Ismeri, vállalja és hitelesen } \\
\text {-képviseli szakmája társadalmi } \\
\text { helyét és szerepét, alapvető vi- } \\
\text { szonyát a világhoz. } \\
\text { - Nyitott szakmája átfogó gon- } \\
\text { dolkodásmódjának és gyakorlati } \\
\text { müködése alapvető jellemzőinek } \\
\text {-hiteles közvetítésére, átadására. } \\
\text { - Folyamatos önképzés igénye } \\
\text { jellemzi. }\end{array}$ & $\begin{array}{l}\text { - Önállóan végzi az átfogó, } \\
\text { megalapozó szakmai kérdések } \\
\text { végiggondolását és adott forrá- } \\
\text { sok alapján történő kidolgozá- } \\
\text { sát } \\
\text { - A szakmát megalapozó néze- } \\
\text { teket felelősséggel vállalja. } \\
\text { - Együttmüködés és felelösség } \\
\text { jellemzi az adott szakterület } \\
\text { képzett szakembereivel. } \\
\text { - Tudatosan vállalja szakmája } \\
\text { etikai normáit. }\end{array}$ \\
\hline
\end{tabular}




\begin{tabular}{|c|c|c|c|c|}
\hline Szint & Tudás & Képességek & Attitüdök & Autonómia és felelősség \\
\hline 7 & $\begin{array}{l}\text { - Ismeri egy adott tanulmányi és/vagy szakterü- } \\
\text { let átfogó tárgykörének általános és specifikus } \\
\text { jellemzőit, legfontosabb irányait és pontosan ki- } \\
\text { dolgozott határait, a szakterületnek a rokon } \\
\text { szakterületekhez való kapcsolódását. } \\
\text { - Részletekbe menően ismeri az adott szak, il- } \\
\text { letve tanulmányi terület összefüggéseit, elméle- } \\
\text { teit és az ezeket felépítő terminológiát. } \\
\text { - Ismeri szakterületének sajátos kutatási (isme- } \\
\text { retszerzési és probléma-megoldási) módszereit, } \\
\text { absztrakciós technikáit, az elvi kérdések gyakor- } \\
\text { lati vonatkozásainak kidolgozási módjait. }\end{array}$ & $\begin{array}{l}\text { - Képes az adott szakterület ismeretrendszerét } \\
\text { alkotó elképzelések különböző területeinek } \\
\text { részletes analízisére, az átfogó és speciális ösz- } \\
\text { szefüggések szintetikus megfogalmazására és az } \\
\text { ezekkel adekvát értékelö tevékenységre. } \\
\text { - Képes speciális szakmai problémák azonosítá- } \\
\text { sára, és azok megoldásához szükséges részletes } \\
\text { elvi és gyakorlati hátér feltárására, megfogalma- } \\
\text { zására. } \\
\text { - Képes a szakmai problémák sokoldalú, inter- } \\
\text { diszciplináris megközelítésére. } \\
\text { - Képes bekapcsolódni kutatási, fejlesztési pro- } \\
\text { jektekbe. } \\
\text { - Magas szinten képes a szakterület ismeretköz- } \\
\text { vetítési technikáit, magyar és idegen nyelvú } \\
\text { publikációs forrásait használni, ezeket feldol- } \\
\text { gozni. } \\
\text { - Különböző bonyolultságú és különböző mér- } \\
\text { tékben kiszámítható kontextusokban képes a } \\
\text { módszerek és technikák széles körének gyakor- } \\
\text { lati alkalmazására. } \\
\text { - Képes szakterületének egyes résztémáiról ön- } \\
\text { álló, szaktudományos formájú összefoglalók, } \\
\text { elemzések készítésére. } \\
\text { - Képes adott munkahely különbözỏ szakmai } \\
\text { elvárásainak megfelelöen felhasználni szakmai } \\
\text { tudását. }\end{array}$ & $\begin{array}{l}\text { - Ismeri és vállalja azokat az át- } \\
\text { fogó és speciális viszonyokat, azt } \\
\text { a szakmai identitást, amelyek } \\
\text { szakterülete sajátos karakterét, } \\
\text { személyes és közösségi szerepét } \\
\text { alkotják. Ez alapozza meg fej- } \\
\text { lödő hivatástudatát. } \\
\text { - Képes szakmája összefoglaló } \\
\text { és részletezett problémaköreinek } \\
\text { megértésére és hiteles közvetíté- } \\
\text { sére. } \\
\text { - Szakmai érdeklődése elmélyül, } \\
\text { megszilárdul. }\end{array}$ & $\begin{array}{l}\text { - Jelentős mértékü önállósággal } \\
\text { rendelkezik átfogó és speciális } \\
\text { szakmai kérdések kidolgozásá- } \\
\text { ban, szakmai nézetek képvise- } \\
\text { letében, indoklásában. } \\
\text { - Felelösséggel vállalja a kez- } \\
\text { deményező szerepét az együtt- } \\
\text { müködés kialakítására. } \\
\text { - Egyenrangú partner a szak- } \\
\text { mai kooperációban. } \\
\text { - Végiggondolja és képviseli az } \\
\text { adott szakterület etikai kérdé- } \\
\text { seit. }\end{array}$ \\
\hline
\end{tabular}




\begin{tabular}{|c|c|c|c|c|}
\hline Szint & Tudás & Képességek & Attitüdök & Autonómia és felelősség \\
\hline 8 & $\begin{array}{l}\text { - Rendelkezik az adott tudományterület tárgy- } \\
\text { körének, általános és specifikus jellemzőinek, } \\
\text { legfontosabb irányainak és pontosan kidolgozott } \\
\text { határainak, megállapodott és vitatott összefüg- } \\
\text { géseinek kutatási szintú ismeretével. } \\
\text { - Alkotó módon megérti az adott szak, illetve } \\
\text { tanulmányi terület összefüggéseit, elméleteit és } \\
\text { az ezeket felépítő fogalmi rendszereket, termi- } \\
\text { nológiát. } \\
\text { - Rendelkezik adott tudomány/szakterület ön- } \\
\text { álló kutatásához szükséges kutatás-módszertani } \\
\text { ismeretekkel. }\end{array}$ & $\begin{array}{l}\text { - Képes az adott szakterület kreatív analízisére, } \\
\text { átfogó és speciális összefüggések szintetikus, új } \\
\text { szemléletü megfogalmazására és az ezekkel } \\
\text { adekvát értékelő és kritikai tevékenységre. } \\
\text { - Alkalmazni, illetve továbbfejleszteni tudja } \\
\text { szakterületének sajátos ismeretszerzési és prob- } \\
\text { léma-megoldási módszereit. } \\
\text { - Képes az elvi kérdések újszerü, eddig ismeret- } \\
\text { len gyakorlati vonatkozásainak kreatív kidolgo- } \\
\text { zására. } \\
\text { - Képes új projektek tervezésére, megvalósítá- } \\
\text { sára, adott tudományterületen kutatást végezni, } \\
\text { új technikákat és megközelítéseket kialakítani. } \\
\text { - Képes előre nem látható szakmai problémák } \\
\text { azonosítására, és az azok megoldásához szüksé- } \\
\text { ges kutatási szintü részletes elvi és gyakorlati } \\
\text { háttér feltárására. } \\
\text { - Képes szakterülete szempontjából lényeges új } \\
\text { viszonyok, a személyes és közösségi lét szem- } \\
\text { pontjából releváns, átfogó összefüggések felépí- } \\
\text { tésére és közvetítésére. }\end{array}$ & $\begin{array}{l}\text { - Képviseli és saját témájához } \\
\text { kapcsolódva továbbfejleszti azo- } \\
\text { kat a relációkat, amelyek a szak- } \\
\text { terület sajátosságából követke- } \\
\text { zően járulnak hozzá az emberi } \\
\text { önteremtés folyamatához. } \\
\text { - Rendelkezik olyan érdeklődés- } \\
\text { see és tanulási képességgel, mely } \\
\text { pillanatban még a átláthatatlan, } \\
\text { előjelezhetetlen kutatási problé- } \\
\text { máinak azonosítását és megoldá- } \\
\text { sát. } \\
\text { - Jellemző viszonyulása a szilárd } \\
\text { szakmai elköteleződés, az új utak } \\
\text { keresésére való elhivatottság ál- } \\
\text { landósulása, a kitartó munkavég- } \\
\text { zés szükségességének elfoga- } \\
\text { dása. }\end{array}$ & $\begin{array}{l}\text { - Alkotó, kreatív önállósággal } \\
\text { épít ki és kezdeményez új tu- } \\
\text { dásterületeket, és kezdeményez } \\
\text { új gyakorlati megoldásokat. } \\
\text { - Vezető szereppel és magas } \\
\text { szintú kooperációval képes } \\
\text { részt venni az elméleti és gya- } \\
\text { korlati kérdések megfogalma- } \\
\text { zásában. } \\
\text { - Képes egyenrangú, vitapart- } \\
\text { neri szerep vitelére a terület } \\
\text { - szakembereivel. } \\
\text { - Felelősséggel vállalja szak- } \\
\text { d mája elméleti és gyakorlati kér- } \\
\text { k dései kapcsán új etikai kérdé- } \\
\text { sek felvetését és megválaszolá- } \\
\text { sát. }\end{array}$ \\
\hline
\end{tabular}




\section{3. melléklet A gazdaságtudományok terület szakjainak képzési és kimeneti követelményei}

\begin{tabular}{|c|c|c|c|c|c|c|c|c|}
\hline $\begin{array}{l}\text { 1. Alkalmazott } \\
\text { közgazdaságtan }\end{array}$ & 2. Gazdaságelemzés & 3. Közszolgálati & $\begin{array}{l}\text { 4. Gazc } \\
\text { men }\end{array}$ & $\begin{array}{r}\text { 5. KeI } \\
\mathrm{m}\end{array}$ & & & & \\
\hline $\begin{array}{l}\text { közgazdasági } \\
\text { kag. }\end{array}$ & jzgazdasági & közgaz & $\begin{array}{l}\text { Képzési ág: üz- } \\
\text { ti }\end{array}$ & Képzési ág: üz- & $\begin{array}{l}\text { 4. Képzési ág: üz- } \\
\text { leti }\end{array}$ & $\begin{array}{l}\text { 4. Képzési ág: üz- } \\
\text { leti }\end{array}$ & : üz- & leti \\
\hline félével & $\begin{array}{l}\text { féléve } \\
\text { félév }\end{array}$ & $\begin{array}{l}\text { féléve } \\
\text { félév }\end{array}$ & $: 7$ & 7 & 6 & 7 & $\begin{array}{l}\text { félével } \\
\text { félév }\end{array}$ & $\begin{array}{l}\text { féléve } \\
\text { félév }\end{array}$ \\
\hline $\begin{array}{l}\text { 6. Az alapfokozat } \\
\text { megszerzéséhez } \\
\text { összegyüjtendő } \\
\text { kreditek száma: } \\
180 \text { kredit }\end{array}$ & $\begin{array}{l}\text { megsze } \\
\text { összegy } \\
\text { kreditel } \\
180 \text { kre }\end{array}$ & $\begin{array}{l}\text { megsz } \\
\text { összeg } \\
\text { kredite } \\
180 \mathrm{kr}\end{array}$ & dő & $\begin{array}{l}\text { megsz } \\
\text { összeg } \\
\text { kredite } \\
180+\end{array}$ & $\begin{array}{l}\text { séhez } \\
\text { tendóma: }\end{array}$ & $\begin{array}{l}\text { ozat } \\
\text { ez } \\
\text { lö } \\
\text { la: } \\
\text { lit }\end{array}$ & $\begin{array}{l}\text { megsze } \\
\text { összegy } \\
\text { kreditp } \\
\text { száma: } \\
\text { kredit }\end{array}$ & $\begin{array}{l}\text { megs } \\
\text { össze } \\
\text { kredit } \\
180+\end{array}$ \\
\hline $\begin{array}{l}\text { 6.1. A képzési } \\
\text { ágon belüli közös } \\
\text { képzési szakasz } \\
\text { minimális kredit- } \\
\text { értéke: } 60 \text { kredit; }\end{array}$ & $\begin{array}{l}\text { zési } \\
\text { i közös } \\
\text { akasz } \\
\text { kredit- } \\
\text { kredit; }\end{array}$ & $\begin{array}{l}\text { ágon } \\
\text { képz } \\
\text { mini } \\
\text { érték }\end{array}$ & $\begin{array}{l}\text { Kozus } \\
\text { rasz } \\
\text { redit- } \\
\text { redit }\end{array}$ & $\begin{array}{l}\text { xasz } \\
\text { redit- } \\
\text { redit; }\end{array}$ & $\begin{array}{l}\text { közös } \\
\text { rasz } \\
\text { redit- } \\
\text { redit }\end{array}$ & $\begin{array}{l}\text { i } \\
\text { özös } \\
\text { sz } \\
\text { dit- } \\
\text { dit }\end{array}$ & $\begin{array}{l}\text { i } \\
\text { jzös } \\
\text { sz } \\
\text { dit- } \\
\text { dit, }\end{array}$ & $\begin{array}{l}\text { i } \\
\text { jzös } \\
\text { sz } \\
\text { dit- } \\
\text { dit }\end{array}$ \\
\hline $\begin{array}{l}\text { kreditér- } \\
\text { kredit; }\end{array}$ & $\begin{array}{l}\text { 6.2. Az szakirány- } \\
\text { hoz rendelhető mi- } \\
\text { nimális kreditér- } \\
\text { ték: } 27 \text { kredit; }\end{array}$ & $\begin{array}{l}6.2 . \\
\text { hoz } \\
\text { nim: } \\
\text { ték: }\end{array}$ & $\begin{array}{l}\text { rány- } \\
\text { etô mi- } \\
\text { litér- } \\
\text { it }\end{array}$ & $\begin{array}{l}\text { rány- } \\
\text { etố mi- } \\
\text { litér- } \\
\text { it; }\end{array}$ & $\begin{array}{l}\text { rány- } \\
\text { etô mi- } \\
\text { litér- } \\
\text { it, }\end{array}$ & $\begin{array}{l}\text { ány- } \\
\text { tő mi- } \\
\text { itér- } \\
\text { t; }\end{array}$ & $\begin{array}{l}\text { ny- } \\
\text { ó mi- } \\
\text { ér- }\end{array}$ & $\begin{array}{l}\text { ány- } \\
\text { tô mi- } \\
\text { tér- }\end{array}$ \\
\hline $\begin{array}{l}\text { 6.3. A szabadon } \\
\text { választható tantár- } \\
\text { gyakhoz rendel- } \\
\text { hető minimális } \\
\text { kreditérték: } 9 \text { kre- } \\
\text { dit; }\end{array}$ & $\begin{array}{l}\text { 6.3. A szabadon } \\
\text { választható tantár- } \\
\text { gyakhoz rendel- } \\
\text { hető minimális } \\
\text { kreditérték: } 9 \text { kre- } \\
\text { dit; }\end{array}$ & $\begin{array}{l}\text { 6.3. A szabadon } \\
\text { választható tantár- } \\
\text { gyakhoz rendel- } \\
\text { hető minimális } \\
\text { kreditérték: } 9 \text { kre- } \\
\text { dit; }\end{array}$ & $\begin{array}{l}\text { 6.3. A szabadon } \\
\text { választható tantár- } \\
\text { gyakhoz rendel- } \\
\text { hető minimális } \\
\text { kreditérték: } 9 \text { kre- } \\
\text { dit }\end{array}$ & $\begin{array}{l}\text { 6.3. A szabadon } \\
\text { választható tantár- } \\
\text { gyakhoz rendel- } \\
\text { hető minimális } \\
\text { kreditérték: } 9 \text { kre- } \\
\text { dit; }\end{array}$ & $\begin{array}{l}\text { 6.3. A szabadon } \\
\text { választható tantár- } \\
\text { gyakhoz rendel- } \\
\text { hető minimális } \\
\text { kreditérték: } 9 \text { kre- } \\
\text { dit }\end{array}$ & $\begin{array}{l}\text { 6.3. A szabadon } \\
\text { választható tantár- } \\
\text { gyakhoz rendel- } \\
\text { hető minimális } \\
\text { kreditérték: } 9 \text { kre- } \\
\text { dit; }\end{array}$ & $\begin{array}{l}\text { 6.3. A szabadon } \\
\text { választható tantár- } \\
\text { gyakhoz rendel- } \\
\text { hető minimális } \\
\text { kreditérték: } 9 \text { kre- } \\
\text { dit, }\end{array}$ & $\begin{array}{l}\text { abadon } \\
\text { ató tantár- } \\
\text { rendel- } \\
\text { himális } \\
\text { ék: } 9 \text { kre- }\end{array}$ \\
\hline
\end{tabular}




\begin{tabular}{|c|c|c|c|c|c|c|c|c|}
\hline $\begin{array}{c}\text { 1. Alkalmazott } \\
\text { közgazdaságtan }\end{array}$ & 2. Gazdaságelemzés & 3. Közszolgálati & $\begin{array}{l}\text { 4. Gazdálkodási és } \\
\text { menedzsment }\end{array}$ & $\begin{array}{l}\text { 5. Kereskedelem és } \\
\text { marketing }\end{array}$ & $\begin{array}{c}\text { 6. Emberi } \\
\text { eröforrások }\end{array}$ & $\begin{array}{l}\text { 7. Nemzetközi } \\
\text { gazdálkodás }\end{array}$ & $\begin{array}{l}\text { 8. Pénzügy és } \\
\text { számvitel }\end{array}$ & $\begin{array}{l}\text { 9. Turizmus- } \\
\text { vendéglátás }\end{array}$ \\
\hline $\begin{array}{l}6.4 \text {. A szakdolgo- } \\
\text { zathoz rendelt kre- } \\
\text { ditérték: kritéri- } \\
\text { umkövetelmény } \\
\text { kredit nélkül; }\end{array}$ & $\begin{array}{l}\text { 6.4. A szakdolgo- } \\
\text { zathoz rendelt kre- } \\
\text { ditérték: kritéri- } \\
\text { umkövetelmény } \\
\text { kredit nélkül; }\end{array}$ & $\begin{array}{l}\text { 6.4. A szakdolgo- } \\
\text { zathoz rendelt kre- } \\
\text { ditérték: kritéri- } \\
\text { umkövetelmény } \\
\text { kredit nélkül; }\end{array}$ & $\begin{array}{l}\text { 6.4. A szakdolgo- } \\
\text { zathoz rendelt kre- } \\
\text { ditérték: kritéri- } \\
\text { umkövetelmény } \\
\text { kredit nélkül }\end{array}$ & $\begin{array}{l}\text { 6.4. A szakdolgo- } \\
\text { zathoz rendelt kre- } \\
\text { ditérték: kritéri- } \\
\text { umkövetelmény } \\
\text { kredit nélkül }\end{array}$ & $\begin{array}{l}\text { 6.4. A szakdolgo- } \\
\text { zathoz rendelt mi- } \\
\text { nimális kreditér- } \\
\text { ték: kritériumkö- } \\
\text { vetelmény kredit } \\
\text { nélkül }\end{array}$ & $\begin{array}{l}\text { 6.4. A szakdolgo- } \\
\text { zathoz rendelt kre- } \\
\text { ditérték: kritéri- } \\
\text { umkövetelmény } \\
\text { kredit nélkül }\end{array}$ & $\begin{array}{l}\text { 6.4. A szakdolgo- } \\
\text { zathoz rendelt mi- } \\
\text { nimális kreditér- } \\
\text { ték: kritériumkö- } \\
\text { vetelmény kredit } \\
\text { nélkül }\end{array}$ & $\begin{array}{l}\text { 6.4. A szakdolgo- } \\
\text { zathoz rendelt kre- } \\
\text { ditérték: kritéri- } \\
\text { umkövetelmény } \\
\text { kredit nélkül }\end{array}$ \\
\hline $\begin{array}{l}\text { 6.5. A gyakorlati } \\
\text { ismeretekhez ren- } \\
\text { delhető minimális } \\
\text { kreditérték: } 60 \\
\text { kredit; } \\
\text { 6.6. Intézményen } \\
\text { kívüli összefüggő } \\
\text { gyakorlati képzés- } \\
\text { ben szerezhető mi- } \\
\text { nimális kreditér- } \\
\text { ték: -. }\end{array}$ & $\begin{array}{l}\text { 6.5. A gyakorlati } \\
\text { ismeretekhez ren- } \\
\text { delhető minimális } \\
\text { kreditérték: } 40 \\
\text { kredit; } \\
\text { 6.6. Intézményen } \\
\text { kívüli összefüggő } \\
\text { gyakorlati képzés- } \\
\text { ben szerezhető mi- } \\
\text { nimális kreditér- } \\
\text { ték: -. }\end{array}$ & $\begin{array}{l}\text { 6.5. A gyakorlati } \\
\text { ismeretekhez ren- } \\
\text { delhető minimális } \\
\text { kreditérték: } 60 \\
\text { kredit; } \\
\text { 6.6. Intézményen } \\
\text { kívüli összefüggő } \\
\text { gyakorlati képzés- } \\
\text { ben szerezhető mi- } \\
\text { nimális kreditér- } \\
\text { ték: - }\end{array}$ & $\begin{array}{l}\text { 6.5. A gyakorlati } \\
\text { ismeretekhez ren- } \\
\text { delhető minimális } \\
\text { kreditérték: } 102 \\
\text { kredit, amelyből } \\
\text { az összefüggő } \\
\text { szakmai gyakorlat } \\
\text { kreditértéke: } 30 \\
\text { kredit. }\end{array}$ & $\begin{array}{l}\text { 6.5. A gyakorlati } \\
\text { ismeretekhez ren- } \\
\text { delhető minimális } \\
\text { kreditérték: } 102 \\
\text { kredit, amelyböl } \\
\text { az összefüggő } \\
\text { szakmai gyakorlat } \\
\text { kreditértéke: } 30 \\
\text { kredit. }\end{array}$ & $\begin{array}{l}\text { 6.5. A gyakorlati } \\
\text { ismeretekhez ren- } \\
\text { delhető minimális } \\
\text { kreditérték: } 72 \\
\text { kredit } \\
\text { 6.6. Intézményen } \\
\text { kívüli összefüggő } \\
\text { szakmai gyakorlati } \\
\text { képzésben szerez- } \\
\text { hető kreditérték:-. }\end{array}$ & $\begin{array}{l}\text { 6.5. A gyakorlati } \\
\text { ismeretekhez ren- } \\
\text { delhető minimális } \\
\text { kreditérték: } 102 \\
\text { kredit, amelyből } \\
\text { az összefüggö } \\
\text { szakmai gyakorlat } \\
\text { kreditértéke: } 30 \\
\text { kredit. }\end{array}$ & $\begin{array}{l}\text { 6.5. A gyakorlati } \\
\text { ismeretekhez ren- } \\
\text { delhető minimális } \\
\text { kredit: } 102 \text { kredit, } \\
\text { amelyből az össze- } \\
\text { függő szakmai } \\
\text { gyakorlat kreditér- } \\
\text { téke: } 30 \text { kredit. }\end{array}$ & $\begin{array}{l}\text { 6.5. A gyakorlati } \\
\text { ismeretekhez ren- } \\
\text { delhető minimális } \\
\text { kreditérték: } 102 \\
\text { kredit, amelyből } \\
\text { az összefüggő } \\
\text { szakmai gyakorlat } \\
\text { kreditértéke: } 30 \\
\text { kredit. }\end{array}$ \\
\hline
\end{tabular}




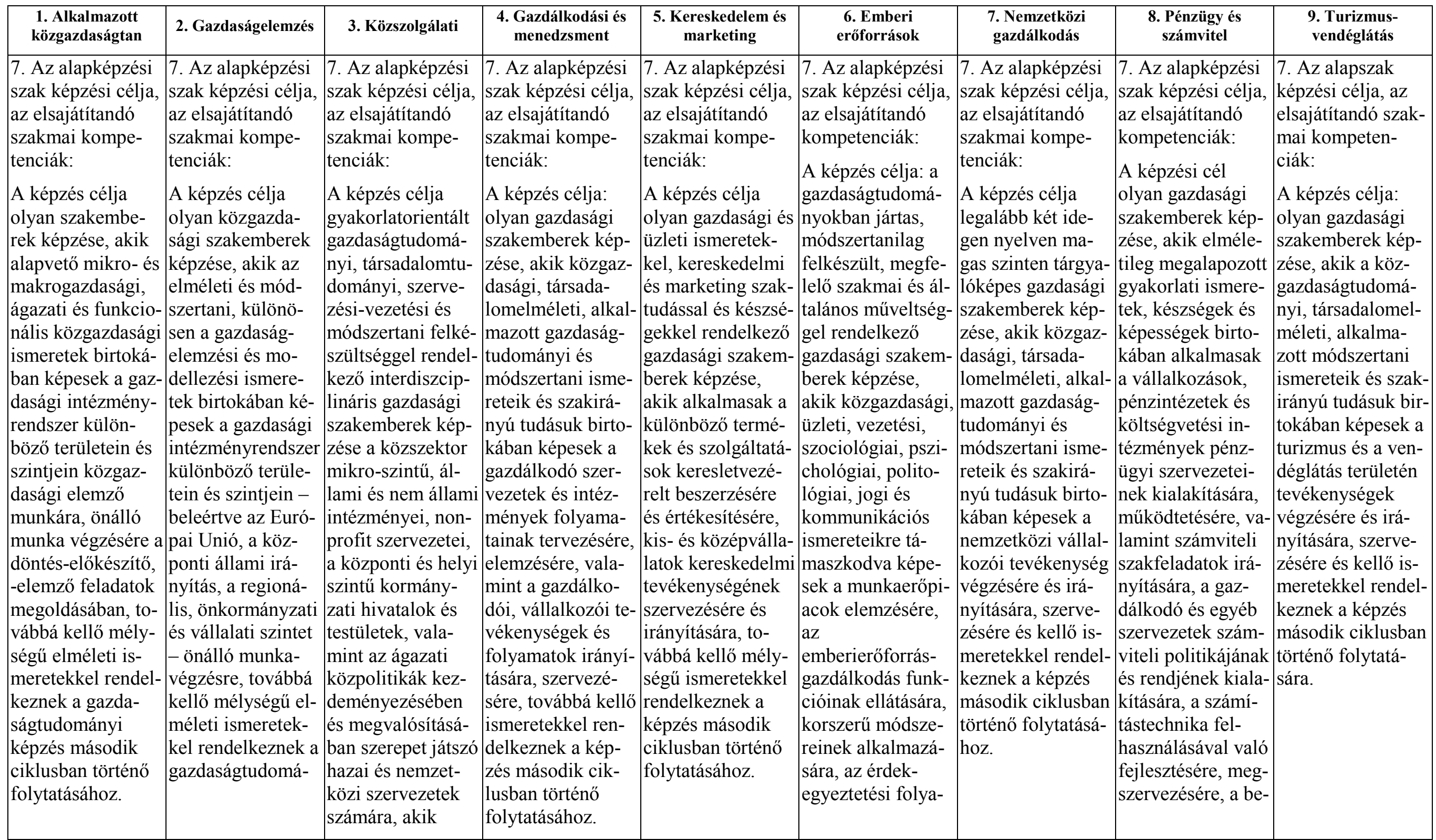




\begin{tabular}{|c|c|c|c|c|c|c|c|c|}
\hline $\begin{array}{l}\text { 1. Alkalmazott } \\
\text { közgazdaságtan }\end{array}$ & 2. Gazdaságelemzés & 3. Közszolgálati & $\begin{array}{l}\text { 4. Gazdálkodási és } \\
\text { menedzsment }\end{array}$ & $\begin{array}{l}\text { 5. Kereskedelem és } \\
\text { marketing }\end{array}$ & $\begin{array}{l}\text { 6. Emberi } \\
\text { eröforrások }\end{array}$ & $\begin{array}{l}\text { 7. Nemzetközi } \\
\text { gazdálkodás }\end{array}$ & $\begin{array}{l}\text { 8. Pénzügy és } \\
\text { számvitel }\end{array}$ & $\begin{array}{l}\text { 9. Turizmus- } \\
\text { vendéglátás }\end{array}$ \\
\hline & $\begin{array}{l}\text { nyi képzés máso- } \\
\text { dik ciklusban tör- } \\
\text { ténő folytatásához. }\end{array}$ & $\begin{array}{l}\text { kellő mélységü el- } \\
\text { méleti ismeretek- } \\
\text { kel rendelkeznek a } \\
\text { képzés második } \\
\text { ciklusban történő } \\
\text { folytatásához. }\end{array}$ & & & $\begin{array}{l}\text { matok koordinálá- } \\
\text { sára, az érintett te- } \\
\text { rületeken szerve- } \\
\text { zési, elemzési, ter- } \\
\text { vezési, döntés-elö- } \\
\text { készítési és szol- } \\
\text { gáltatási feladatok } \\
\text { megoldására, to- } \\
\text { vábbá a megszer- } \\
\text { zett ismereteik } \\
\text { alapján alkalma- } \\
\text { sak tanulmányaik } \\
\text { mesterképzési sza- } \\
\text { kon történő folyta- } \\
\text { tásához. }\end{array}$ & & $\begin{array}{l}\text { számolási kötele- } \\
\text { zettség teljesíté- } \\
\text { sére, a költséggaz- } \\
\text { dálkodás rendsze- } \\
\text { rének kialakítá- } \\
\text { sára, fejlesztésére, } \\
\text { müködtetésére, a } \\
\text { gazdálkodás elem- } \\
\text { zésére, értékelé- } \\
\text { sére és ellenörzé- } \\
\text { sére, továbbá kellő } \\
\text { ismeretekkel ren- } \\
\text { delkeznek a kép- } \\
\text { zés második ciklu- } \\
\text { sában történő foly- } \\
\text { tatásához. }\end{array}$ & \\
\hline $\begin{array}{l}\text { Az alapfokozat } \\
\text { birtokában az al- } \\
\text { kalmazott közgaz- } \\
\text { daságtan alapkép- } \\
\text { zési szakon végzet- } \\
\text { tek ismerik: } \\
\text { - a gazdasági fo- } \\
\text { galmakat, össze- } \\
\text { függéseket és } \\
\text { elemzési módsze- } \\
\text { reket, } \\
\text { - a gazdálkodás } \\
\text { különböző terüle- } \\
\text { teinek alapvető el- } \\
\text { veit és eszközeit, }\end{array}$ & $\begin{array}{l}\text { Az alapfokozat } \\
\text { birtokában a gaz- } \\
\text { daságelemzés } \\
\text { alapképzési sza- } \\
\text { kon végzettek is- } \\
\text { merik: } \\
\text { - a közgazdasági } \\
\text { elméleteket és } \\
\text { módszereket, kü- } \\
\text { lönösen azok ma- } \\
\text { tematikai alapjait, } \\
\text { - a gazdaság in- } \\
\text { tézményrendszerét } \\
\text {, müködésük elveit } \\
\text { és folyamatait, }\end{array}$ & $\begin{array}{l}\text { Az alapfokozat } \\
\text { birtokában a köz- } \\
\text { szolgálati alap- } \\
\text { képzési szakon } \\
\text { végzettek ismerik: } \\
\text { - a közszektor } \\
\text { gazdaságtanának } \\
\text { alapvetö összefüg- } \\
\text { géseit, } \\
\text { - a közszolgáltató } \\
\text { és non-profit szer- } \\
\text { vezetek müködési } \\
\text { elveit és rendsze- } \\
\text { rét, folyamatait, } \\
\text { - a szervezetfej- } \\
\text { lesztés, szervezeti }\end{array}$ & $\begin{array}{l}\text { Az alapfokozat } \\
\text { birtokában a gaz- } \\
\text { dálkodási és me- } \\
\text { nedzsment alap- } \\
\text { képzési szakon } \\
\text { végzettek ismerik: } \\
\text { - a gazdálkodás } \\
\text { alapfogalmait, fő } \\
\text { összefüggéseit, a } \\
\text { gazdálkodásra } \\
\text { ható tényezőket és } \\
\text { azok befolyásolá- } \\
\text { sára használatos } \\
\text { módszereket, }\end{array}$ & $\begin{array}{l}\text { Az alapfokozat } \\
\text { birtokában a ke- } \\
\text { reskedelem és } \\
\text { marketing szakon } \\
\text { végzettek ismerik: } \\
\text { - a társadalmi, } \\
\text { gazdasági, piaci } \\
\text { környezetet, me- } \\
\text { chanizmusait, } \\
\text { szervezeteit, mü- } \\
\text { ködési elveit, fej- } \\
\text { lődési trendjeit, } \\
\text { - a marketing fo- } \\
\text { galmát, koncepci- } \\
\text { óját, eszközrend- }\end{array}$ & $\begin{array}{l}\text { Az alapfokozat } \\
\text { birtokában az em- } \\
\text { beri eröforrások } \\
\text { alapképzési sza- } \\
\text { kon végzettek is- } \\
\text { merik: } \\
\text { - a gazdálkodás } \\
\text { fogalmait, legfon- } \\
\text { tosabb összefüg- } \\
\text { géseit és a gazdál- } \\
\text { kodást meghatá- } \\
\text { rozó tényezőket, } \\
\text { - az erőforrások- } \\
\text { kal, ezen belül az } \\
\text { emberi erőforrá- }\end{array}$ & $\begin{array}{l}\text { Az alapfokozat } \\
\text { birtokában a nem- } \\
\text { zetközi gazdálko- } \\
\text { dási alapképzési } \\
\text { szakon végzettek } \\
\text { ismerik: } \\
\text { - a nemzetközi } \\
\text { gazdasági folya- } \\
\text { matok elméleti } \\
\text { összefüggéseit, } \\
\text { hátterét, } \\
\text { - a nemzetközi } \\
\text { gazdasági és piaci } \\
\text { folyamatokat, }\end{array}$ & $\begin{array}{l}\text { Az alapfokozat } \\
\text { birtokában a pénz- } \\
\text { ügy és számvitel } \\
\text { alapképzési sza- } \\
\text { kon végzettek is- } \\
\text { merik: } \\
\text { - a nemzetgazda- } \\
\text { sági ágak helyze- } \\
\text { tét, fejlődésük fö } \\
\text { törvényszerüsé- } \\
\text { geit, } \\
\text { - a vállalati gaz- } \\
\text { dálkodás céljait, } \\
\text { alapvető törvény- } \\
\text { szerüségeit, }\end{array}$ & $\begin{array}{l}\text { Az alapfokozat } \\
\text { birtokában a turiz- } \\
\text { mus-vendéglátás } \\
\text { alapképzési sza- } \\
\text { kon végzettek is- } \\
\text { merik: } \\
\text { - a turisztikai ága- } \\
\text { zat müködésének } \\
\text { elveit és jellem- } \\
\text { zőit, annak kap- } \\
\text { csolódó ágazatait } \\
\text { (szállásadás, ven- } \\
\text { déglátás, utazás- } \\
\text { szervezés, rendez- } \\
\text { vényszervezés), }\end{array}$ \\
\hline
\end{tabular}




\begin{tabular}{|c|c|c|c|c|c|c|c|c|}
\hline $\begin{array}{l}\text { 1. Alkalmazott } \\
\text { közgazdaságtan }\end{array}$ & 2. Gazdaságelemzés & 3. Közszolgálati & $\begin{array}{l}\text { 4. Gazdálkodási és } \\
\text { menedzsment }\end{array}$ & $\begin{array}{l}\text { 5. Kereskedelem és } \\
\text { marketing }\end{array}$ & $\begin{array}{c}\text { 6. Emberi } \\
\text { eröforrások }\end{array}$ & $\begin{array}{l}\text { 7. Nemzetközi } \\
\text { gazdálkodás }\end{array}$ & $\begin{array}{l}\text { 8. Pénzügy és } \\
\text { számvitel }\end{array}$ & $\begin{array}{l}\text { 9. Turizmus- } \\
\text { vendéǵátás }\end{array}$ \\
\hline $\begin{array}{l}\text { - a gazdasági kap- } \\
\text { csolatok és intéz- } \\
\text { mények rendsze- } \\
\text { rét, müködésük el- } \\
\text { veit és folyama- } \\
\text { tait, } \\
\text { - a gazdasági erő- } \\
\text { forrásokkal való } \\
\text { gazdálkodás, vala- } \\
\text { mint a gazdasági } \\
\text { szervezés és irá- } \\
\text { nyítás alapelveit és } \\
\text { módszereit, } \\
\text { - a nemzetközi } \\
\text { gazdaság müködé- } \\
\text { sének törvénysze- } \\
\text { rüségeit, benne ki- } \\
\text { emelten az EU } \\
\text { müködési rendsze- } \\
\text { rét és politikáit. }\end{array}$ & \begin{tabular}{|l|} 
- az információ- \\
szerzés és -elem- \\
zés módszereit, \\
- a nemzeti és \\
nemzetközi gazda- \\
ság müködésének \\
törvényszerüsé- \\
geit, a gazdasági \\
folyamatok szer- \\
vezésének és irá- \\
nyításának alapel- \\
veit és módszereit, \\
- a gazdasági erö- \\
forrásokkal való \\
gazdálkodás alap- \\
elveit és modell- \\
jeit, \\
- a gazdasági sze- \\
replők döntéseit \\
alakító tényezőket, \\
az egyes döntések \\
komplex kölcsön- \\
hatásának rendsze- \\
rét és az azok gya- \\
korlati elemzésére \\
alkalmas modelle- \\
ket, módszereket, \\
illetve a gazdasági \\
információs rend- \\
szereket,
\end{tabular} & $\begin{array}{l}\text { folyamatok és } \\
\text { rendszerek, irányí- } \\
\text { tás, személyzeti } \\
\text { menedzsment, } \\
\text { kompetenciafej- } \\
\text { lesztés, intézményi } \\
\text { kultúra, tervezési } \\
\text { stratégia alapvető } \\
\text { szakismereteit, } \\
\text { - az EU müködé- } \\
\text { sének és szakpoli- } \\
\text { tikáinak fö jellem- } \\
\text { zőit, } \\
\text { - a közpolitika } \\
\text { megvalósításának } \\
\text { folyamatát és a fo- } \\
\text { lyamat befolyáso- } \\
\text { lásának alapvető } \\
\text { eszközrendszerét, } \\
\text { - a költségvetési } \\
\text { gazdálkodás és } \\
\text { közszolgálati me- } \\
\text { nedzsment alapfo- } \\
\text { galmait, fö össze- } \\
\text { függéseit, a gaz- } \\
\text { dálkodásra ható té- } \\
\text { nyezőket, és az } \\
\text { azok befolyásolá- } \\
\text { sára használatos } \\
\text { átfogó módszere- } \\
\text { ket, }\end{array}$ & $\begin{array}{l}\text { - az erőforrások- } \\
\text { kal, termelési té- } \\
\text { nyezőkkel való } \\
\text { gazdálkodás irány- } \\
\text { elveit, tervezési, } \\
\text { elemzési, értéke- } \\
\text { lési, lebonyolítási } \\
\text { eszközeit, módsze- } \\
\text { reit, } \\
\text { - a gazdálkodási } \\
\text { folyamatok irányí- } \\
\text { tásának, szervezé- } \\
\text { sének és múködte- } \\
\text { tésének alapelveit } \\
\text { és módszereit, } \\
\text { - a szervezetek és } \\
\text { intézmények létre- } \\
\text { hozására, struktú- } \\
\text { rájuk, szervezeti } \\
\text { magatartásuk ki- } \\
\text { alakítására és vál- } \\
\text { toztatására vonat- } \\
\text { kozó alapelveket } \\
\text { és módszereket. }\end{array}$ & $\begin{array}{l}\text { szerét és módszer- } \\
\text { tanát az üzleti és } \\
\text { non-profit szférá- } \\
\text { ban, } \\
\text { - a marketing sze- } \\
\text { repét a vállalat, in- } \\
\text { tézmény müködé- } \\
\text { sében, a marketing } \\
\text { kapcsolatát a szer- } \\
\text { vezet más folya- } \\
\text { mataival, funkciói- } \\
\text { val, } \\
\text { - a fogyasztói, ve- } \\
\text { vői magatartás fo- } \\
\text { lyamatát, a fo- } \\
\text { gyaszztóvédelem } \\
\text { területét, } \\
\text { - az értékesítési, } \\
\text { üzletkötési tevé- } \\
\text { kenység folyama- } \\
\text { tait, jogi, etikai } \\
\text { követelményeit, } \\
\text { - a kereskedelmi } \\
\text { vállalatok mükö- } \\
\text { dését és szerveze- } \\
\text { tét, a kereskedelmi } \\
\text { tevékenység föbb } \\
\text { munkafolyamatait } \\
\text { és technikáit. } \\
\text { - a logisztikai fo- } \\
\text { lyamatokat, }\end{array}$ & \begin{tabular}{|l|} 
sokkal való gaz- \\
dálkodás korszerü \\
eljárásait, terve- \\
zési, elemzési és \\
értékelési módsze- \\
reit, \\
- az \\
emberierőforrás- \\
gazdálkodás szer- \\
vezeti és informá- \\
ciós rendszerének \\
müködését, \\
- a kompetenciák \\
fejlesztésének az \\
egyéni és szerve- \\
zeti képességekre \\
gyakorolt hatását, \\
az emberi tőkebe- \\
fektetések és hoza- \\
mok vizsgálatát, \\
- a munkaerö-pi- \\
aci, érdekegyezte- \\
tési és \\
emberierőforrás- \\
fejlesztési folya- \\
matok elemzését \\
és koordinálását, \\
az ezzel kapcsola- \\
tos döntés-előké- \\
szítési feladatok
\end{tabular} & $\begin{array}{l}\text {-az európai integ- } \\
\text { rációs folyamatot, } \\
\text { az EU múködését, } \\
\text { - a globalizáció } \\
\text { folyamatait, moz- } \\
\text { gatórugóit, és ha- } \\
\text { tását az egyes ré- } \\
\text { giókra, } \\
\text { - a nemzetközi pi- } \\
\text { acmüködés és ver- } \\
\text { seny elemzésének } \\
\text { módszertani kér- } \\
\text { déseit, } \\
\text { - a nemzetközi ke- } \\
\text { reskedelempolitika } \\
\text { célkitúzéseit, esz- } \\
\text { közrendszerét, } \\
\text { - a nemzetközi } \\
\text { pénzügyek tör- } \\
\text { vényszerüségeit, } \\
\text { szereplöit, a nem- } \\
\text { zetközi pénzügyek } \\
\text { technikáját, } \\
\text { - Magyarország } \\
\text { helyét és szerepét } \\
\text { a világgazdaság- } \\
\text { ban, az euró-at- } \\
\text { lanti integráció- } \\
\text { ban, }\end{array}$ & $\begin{array}{l}\text { - a vállalati gaz- } \\
\text { dálkodás finanszí- } \\
\text { rozási-számviteli- } \\
\text { adózási alrendsze- } \\
\text { rét, a vállalati fi- } \\
\text { nanszírozás alap- } \\
\text { elveit, közvetlen } \\
\text { és közvetett finan- } \\
\text { szírozás formáit, } \\
\text { - a pénzügyi, } \\
\text { számviteli folya- } \\
\text { matok tervezésé- } \\
\text { nek, szervezésé- } \\
\text { nek, irányításának, } \\
\text { ellenörzésének el- } \\
\text { méleti alapjait és } \\
\text { gyakorlatát, az ér- } \\
\text { tékelés technikáit, } \\
\text { - a vállalkozások } \\
\text { tevékenységét sza- } \\
\text { bályozó jogszabá- } \\
\text { lyokat, a vállalat } \\
\text { piaci alkalmazko- } \\
\text { dásának legfonto- } \\
\text { sabb pénzügyi fel- } \\
\text { tételeit, } \\
\text { - a hazai és nem- } \\
\text { zetközi adózási, } \\
\text { számviteli szabá- } \\
\text { lyokat, a vállalko- } \\
\text { zások müködésé- }\end{array}$ & $\begin{array}{l}\text { - a vendéglátás el- } \\
\text { veit és gazdaságta- } \\
\text { nát, } \\
\text { - a turizmus sze- } \\
\text { replöinek, érde- } \\
\text { keltjeinek és érin- } \\
\text { tettjeinek jellem- } \\
\text { zőit, } \\
\text { - a turisták által } \\
\text { igénybe vehető } \\
\text { szolgáltatások } \\
\text { rendszerét, } \\
\text { - a különböző tí- } \\
\text { pusú turisztikai } \\
\text { vállalkozások } \\
\text { (szálláshelyek, } \\
\text { vendéglátóhelyek, } \\
\text { szabadidős létesít- } \\
\text { mények) szervezé- } \\
\text { sére, múködteté- } \\
\text { sére és irányítására } \\
\text { vonatkozó elveket } \\
\text { és módszereket, } \\
\text { - a turisztikai } \\
\text { szolgáltatások fo- } \\
\text { lyamatait, lebo- } \\
\text { nyolításuk feltét- } \\
\text { eleit és a legfonto- } \\
\text { sabb vonatkozó } \\
\text { jogszabályi elöírá- } \\
\text { sokat, }\end{array}$ \\
\hline
\end{tabular}




\begin{tabular}{|c|c|c|c|c|c|c|c|c|}
\hline $\begin{array}{l}\text { 1. Alkalmazott } \\
\text { közgazdaságtan }\end{array}$ & 2. Gazdaságelemzés & 3. Közszolgálati & $\begin{array}{l}\text { 4. Gazdálkodási és } \\
\text { menedzsment }\end{array}$ & $\begin{array}{l}\text { 5. Kereskedelem és } \\
\text { marketing }\end{array}$ & $\begin{array}{l}\text { 6. Emberi } \\
\text { eröforrások }\end{array}$ & $\begin{array}{l}\text { 7. Nemzetközi } \\
\text { gazdálkodás }\end{array}$ & $\begin{array}{l}\text { 8. Pénzügy és } \\
\text { számvitel }\end{array}$ & $\begin{array}{l}\text { 9. Turizmus- } \\
\text { vendéglátás }\end{array}$ \\
\hline & $\begin{array}{l}\text { - az EU müködési } \\
\text { rendszerét és poli- } \\
\text { tikáit. }\end{array}$ & $\begin{array}{l}\text { - a köz- és non- } \\
\text { profit szervezetek } \\
\text { létrehozására, } \\
\text { szervezésére, mü- } \\
\text { ködtetésére és irá- } \\
\text { nyítására, fejlesz- } \\
\text { tésére vonatkozó } \\
\text { alapvető elveket és } \\
\text { módszereket, } \\
\text { - a közjót előmoz- } \\
\text { dító döntési javas- } \\
\text { latok kidolgozásá- } \\
\text { hoz szükséges } \\
\text { problémaelemzés } \\
\text { és megoldáselem- } \\
\text { zés alapvető mód- } \\
\text { szereit. }\end{array}$ & & $\begin{array}{l}\text { - az e-üzlet mód- } \\
\text { szereit és hátterét } \\
\text { - képesek a mar- } \\
\text { keting értékesítés } \\
\text { rövid és középtávú } \\
\text { döntési folyamata- } \\
\text { iban való eligazo- } \\
\text { dásra, a gyors pi- } \\
\text { aci változások fel- } \\
\text { ismerésére, azok- } \\
\text { hoz való alkalmaz- } \\
\text { kodásra. }\end{array}$ & $\begin{array}{l}\text { megoldását az üz- } \\
\text { leti életben és a } \\
\text { közszolgálatban. }\end{array}$ & $\begin{array}{l}\text { - Magyarország } \\
\text { külgazdasági fo- } \\
\text { lyamatainak dina- } \\
\text { mizmusát, föbb pi- } \\
\text { acait, } \\
\text { - az erőforrások } \\
\text { pályázati úton való } \\
\text { megszerzésének és } \\
\text { felhasználásának } \\
\text { lehetőségeit és } \\
\text { technikáját, } \\
\text { - a nemzetközi } \\
\text { versenyhelyzetben } \\
\text { meghozandó stra- } \\
\text { tégiai üzleti dönté- } \\
\text { sek marketing vo- } \\
\text { natkozásait és vég- } \\
\text { rehajtásuk eszköz- } \\
\text { rendszerét, } \\
\text { - a világméretü } \\
\text { árumozgások lo- } \\
\text { gisztikai vonatko- } \\
\text { zásait, } \\
\text { - a nemzetközi } \\
\text { ügyletek jellegze- } \\
\text { tes típusait, folya- } \\
\text { matait, jogi vonat- } \\
\text { kozásait, }\end{array}$ & $\begin{array}{l}\text { nek (alapítás, mü- } \\
\text { ködés, átalakulás, } \\
\text { megszüntetés) } \\
\text { számviteli, pénz- } \\
\text { ügyi megjeleníté- } \\
\text { sét, } \\
\text { - a számviteli in- } \\
\text { formációs rend- } \\
\text { szert, a beszámoló } \\
\text { részeit, illetve az } \\
\text { azt alátámasztó } \\
\text { könyvelési folya- } \\
\text { matokat, a tevé- } \\
\text { kenységek elem- } \\
\text { zésének módszer- } \\
\text { tanát, a döntés- } \\
\text { elökészités mód- } \\
\text { szertani alapjait, } \\
\text { - a pénzintézeti } \\
\text { rendszer felépíté- } \\
\text { sét, az egyes pénz- } \\
\text { intézeti típusok sa- } \\
\text { játosságait, a hite- } \\
\text { lezési folyamatot, } \\
\text { az értékpapír-piac } \\
\text { müködésének fon- } \\
\text { tosabb elemeit, } \\
\text { - az állambáztar- } \\
\text { tás feladatait és } \\
\text { felépítését, }\end{array}$ & $\begin{array}{l}\text { - a turizmussal } \\
\text { kapcsolatos közös- } \\
\text { ségi és non profit } \\
\text { tevékenységeket, } \\
\text { államigazgatási, } \\
\text { önkormányzati, te- } \\
\text { rületfejlesztési, } \\
\text { kulturális kapcso- } \\
\text { lódásukat, a turiz- } \\
\text { mus hazai és nem- } \\
\text { zetközi intéz- } \\
\text { ményrendszerét, } \\
\text { - a turisztikai vál- } \\
\text { lalkozások múkö- } \\
\text { dését befolyásoló } \\
\text { földrajzi, kulturá- } \\
\text { lis, természeti és } \\
\text { jogi vonatkozáso- } \\
\text { kat, } \\
\text { - a turisztikai vál- } \\
\text { lalatok egyes mü- } \\
\text { ködési területeinek } \\
\text { (marketing, pénz- } \\
\text { ügy, finanszírozás, } \\
\text { emberi erőforrás, } \\
\text { menedzsment, } \\
\text { kontrolling, stb.) } \\
\text { sajátosságait, el- } \\
\text { veit és módsze- } \\
\text { reit,- a választott } \\
\text { szakiránynak meg- } \\
\text { felelö alágazat } \\
\text { vagy tevékenység }\end{array}$ \\
\hline
\end{tabular}




\begin{tabular}{|c|c|c|c|c|c|c|c|c|}
\hline $\begin{array}{l}\text { 1. Alkalmazott } \\
\text { közgazdaságtan }\end{array}$ & 2. Gazdaságelemzés & 3. Közszolgálati & $\begin{array}{l}\text { 4. Gazdálkodási és } \\
\text { menedzsment }\end{array}$ & $\begin{array}{c}\text { 5. Kereskedelem és } \\
\text { marketing }\end{array}$ & $\begin{array}{c}\text { 6. Emberi } \\
\text { eröforrások }\end{array}$ & $\begin{array}{l}\text { 7. Nemzetközi } \\
\text { gazdálkodás }\end{array}$ & $\begin{array}{l}\text { 8. Pénzügy és } \\
\text { számvitel }\end{array}$ & $\begin{array}{l}\text { 9. Turizmus- } \\
\text { vendéglátás }\end{array}$ \\
\hline & & & & & & $\begin{array}{l}\text { - a nemzetközi } \\
\text { menedzsment in- } \\
\text { terkulturális vo- } \\
\text { natkozásait, } \\
\text { - a nemzetközi üz- } \\
\text { leti élet viselke- } \\
\text { dési szabályait, a } \\
\text { protokoll és etikett } \\
\text { elöírásait, } \\
\text { - a nemzetközi } \\
\text { gazdasági szerve- } \\
\text { zetek müködését. }\end{array}$ & $\begin{array}{l}\text { - a vállalkozási és } \\
\text { közszféra mükö- } \\
\text { dési törvényszerü- } \\
\text { ségeinek fö kü- } \\
\text { lönbségeit, } \\
\text { - a költségvetési } \\
\text { gazdálkodás alap- } \\
\text { vetö törvényszerü- } \\
\text { ségeit, a költség- } \\
\text { vetési finanszíro- } \\
\text { zás alapelveit és } \\
\text { lehetséges techni- } \\
\text { káit. }\end{array}$ & $\begin{array}{l}\text { - például szállás- } \\
\text { helyek, vendéglá- } \\
\text { tás, utazásszerve- } \\
\text { zés, rekreáció, tér- } \\
\text { ség-menedzselés - } \\
\text { működését, értéke- } \\
\text { lési és döntési kri- } \\
\text { tériumait, szakmai } \\
\text { részterületeit, ága- } \\
\text { zati kapcsolódási } \\
\text { pontjait. }\end{array}$ \\
\hline $\begin{array}{l}\text { Az alapfokozat } \\
\text { birtokában az al- } \\
\text { kalmazott közgaz- } \\
\text { daságtan alapkép- } \\
\text { zési szakon végzet- } \\
\text { tek alkalmasak: } \\
\text { - a gazdasági } \\
\text { problémák felis- } \\
\text { merésére és a } \\
\text { megoldásukra irá- } \\
\text { nyuló döntések } \\
\text { elökészítésére, a } \\
\text { szükséges infor- } \\
\text { mációk beszerzé- } \\
\text { sére és elemzé- } \\
\text { sére, } \\
\text { - a megszerzett tu- } \\
\text { dás alkalmazására, }\end{array}$ & \begin{tabular}{|l} 
Az alapfokozat \\
birtokában a gaz- \\
daságelemzés \\
alapképzési sza- \\
kon végzettek al- \\
kalmasak: \\
- a különböző \\
gazdasági folya- \\
matok elemzésére, \\
tervezésére, irá- \\
nyítására, \\
- az önálló és cso- \\
portos gazdasági \\
elemzések végzé- \\
sére, kollektív \\
döntések előkészí- \\
tésében való rész- \\
vételre,
\end{tabular} & $\begin{array}{l}\text { Az alapfokozat } \\
\text { birtokában a köz- } \\
\text { szolgálati alap- } \\
\text { képzési szakon } \\
\text { végzettek alkalma- } \\
\text { sak: } \\
\text { - a valóságos köz- } \\
\text { politikai problé- } \\
\text { mák és megoldá- } \\
\text { sok, továbbá a ren- } \\
\text { delkezésre álló } \\
\text { erőforrások krea- } \\
\text { tív alapfokú elem- } \\
\text { zésére, } \\
\text { - a közszektor } \\
\text { szervezeteiben és } \\
\text { intézményeiben } \\
\text { elemző, tervező és }\end{array}$ & $\begin{array}{l}\text { Az alapfokozat } \\
\text { birtokában a gaz- } \\
\text { dálkodási és me- } \\
\text { nedzsment alap- } \\
\text { képzési szakon } \\
\text { végzettek alkalma- } \\
\text { sak: } \\
\text { - a gazdálkodó } \\
\text { szervezetekben } \\
\text { szakképzettségük- } \\
\text { nek megfelelö } \\
\text { munkakörök be- } \\
\text { töltésére, } \\
\text { - a problémameg- } \\
\text { oldó technikák } \\
\text { vállalati döntések } \\
\text { előkészítésében }\end{array}$ & $\begin{array}{l}\text { Az alapfokozat } \\
\text { birtokában a ke- } \\
\text { reskedelem és } \\
\text { marketing szakon } \\
\text { végzettek alkalma- } \\
\text { sak: } \\
\text { - kis- és középvál- } \\
\text { lalatok kereske- } \\
\text { delmi tevékenysé- } \\
\text { gének szervezé- } \\
\text { sére és irányítá- } \\
\text { sára, } \\
\text { - különböző ter- } \\
\text { mékek és szolgál- } \\
\text { tatások beszerzé- } \\
\text { sére és értékesíté- } \\
\text { sére, }\end{array}$ & \begin{tabular}{|l} 
Az alapfokozat \\
birtokában az em- \\
beri eröforrások \\
alapképzési sza- \\
kon végzettek al- \\
kalmasak: \\
- a gazdaság kü- \\
lönböző területein \\
müködő szerveze- \\
tekben, illetőleg \\
vállalkozásokban \\
az emberi erőfor- \\
rások fejlesztését \\
és hasznosítását \\
elősegítő gazdál- \\
kodási, elemzési \\
és tervezési fel- \\
adatok ellátására,
\end{tabular} & $\begin{array}{l}\text { Az alapfokozat } \\
\text { birtokában a nem- } \\
\text { zetközi gazdálko- } \\
\text { dási alapképzési } \\
\text { szakon végzettek } \\
\text { alkalmasak: } \\
\text { - a nemzetközi } \\
\text { áru, szolgáltatások } \\
\text { és pénzügyi moz- } \\
\text { gások elemzésére, } \\
\text { - regionális és ha- } \\
\text { zai relációkban } \\
\text { való párhuzamos } \\
\text { gondolkodásra, } \\
\text { - nemzetközi tár- } \\
\text { gyalások önálló } \\
\text { vitelére, }\end{array}$ & $\begin{array}{l}\text { Az alapfokozat } \\
\text { birtokában a pénz- } \\
\text { ügy és számvitel } \\
\text { alapképzési sza- } \\
\text { kon végzettek al- } \\
\text { kalmasak: } \\
\text { - a pénzügyi, be- } \\
\text { fektetési, finanszí- } \\
\text { rozási, beruházási } \\
\text { döntések előkészí- } \\
\text { tésére, a hitelké- } \\
\text { relmek, pénzügyi } \\
\text { tervek, pályázatok } \\
\text { készítésére, érté- } \\
\text { kelésére, } \\
\text { - önálló finanszí- } \\
\text { rozási döntésekre, }\end{array}$ & $\begin{array}{l}\text { Az alapfokozat } \\
\text { birtokában a turiz- } \\
\text { mus-vendéglátás } \\
\text { alapképzési sza- } \\
\text { kon végzettek al- } \\
\text { kalmasak: } \\
\text { - az egyes turiszti- } \\
\text { kai szakterületen } \\
\text { jelentkező felada- } \\
\text { tok és munkakö- } \\
\text { rök ellátására, } \\
\text { - a turisztikai vál- } \\
\text { lalkozásoknál ve- } \\
\text { zetői feladatok el- } \\
\text { látására, } \\
\text { - többnyelvű és } \\
\text { különböző funkci- }\end{array}$ \\
\hline
\end{tabular}




\begin{tabular}{|c|c|c|c|c|c|c|c|c|}
\hline $\begin{array}{l}\text { 1. Alkalmazott } \\
\text { közgazdaságtan }\end{array}$ & 2. Gazdaságelemzés & 3. Közszolgálati & $\begin{array}{l}\text { 4. Gazdálkodási és } \\
\text { menedzsment }\end{array}$ & $\begin{array}{l}\text { 5. Kereskedelem és } \\
\text { marketing }\end{array}$ & $\begin{array}{l}\text { 6. Emberi } \\
\text { eröforrások }\end{array}$ & $\begin{array}{l}\text { 7. Nemzetközi } \\
\text { gazdálkodás }\end{array}$ & $\begin{array}{l}\text { 8. Pénzügy és } \\
\text { számvitel }\end{array}$ & İ́átás \\
\hline $\begin{array}{l}\text { gazdasági folya- } \\
\text { matok tervezésé- } \\
\text { vel és irányításá- } \\
\text { val kapcsolatos } \\
\text { feladatok megol- } \\
\text { dására, } \\
\text { - elemzések, je- } \\
\text { lentések, } \\
\text { felmérések elké- } \\
\text { szítésére, } \\
\text { - önálló és cso- } \\
\text { portmunka végzé- } \\
\text { sére. } \\
\text { Rendelkeznek ön- } \\
\text { álló problémafelis- } \\
\text { merő és megoldó } \\
\text { készséggel, inno- } \\
\text { vációs készzéggel, } \\
\text { kritikai elemző és } \\
\text { javaslattevő (kez- } \\
\text { deményezö) kész- } \\
\text { séggel, társadalmi } \\
\text { kérdések iránti ér- } \\
\text { zékenységgel, szó- } \\
\text { beli és írásbeli } \\
\text { kommunikációs } \\
\text { készséggel, tole- } \\
\text { rancia és szinergia } \\
\text { lehetősége felis- } \\
\text { merésének képes- } \\
\text { ségével. }\end{array}$ & $\begin{array}{l}\text { - a gazdaságelem- } \\
\text { zési módszerek in- } \\
\text { novatív és kreatív } \\
\text { alkalmazására, } \\
\text { - a stratégiai jel- } \\
\text { legú gazdaság- és } \\
\text { vállalatpolitikai } \\
\text { problémák felis- } \\
\text { merésére, ill. a } \\
\text { megoldásukra irá- } \\
\text { nyuló döntések } \\
\text { előkészítésére, } \\
\text { - elemzések, je- } \\
\text { lentések, felméré- } \\
\text { sek készítésére } \\
\text { magyar és leg- } \\
\text { alább egy idegen } \\
\text { nyelven, } \\
\text { - önálló és cso- } \\
\text { portmunka végzé- } \\
\text { sére. } \\
\text { Rendelkeznek ön- } \\
\text { álló problémafelis- } \\
\text { merő és megoldó } \\
\text { készséggel, inno- } \\
\text { vációs készséggel, } \\
\text { kritikai elemző és } \\
\text { javaslattevő (kez- } \\
\text { deményezó) kész- } \\
\text { séggel, társadalmi } \\
\text { kérdések iránti ér- }\end{array}$ & $\begin{array}{l}\text { középszintü irá- } \\
\text { nyító munka foly- } \\
\text { tatására, } \\
\text { - a pénzügyi, köz- } \\
\text { menedzsment, és } \\
\text { információtechni- } \\
\text { kai ismeretek ösz- } \\
\text { szetett alkalmazá- } \\
\text { sára, } \\
\text { - szakterületi je- } \\
\text { lentések, felméré- } \\
\text { sek elkészítésében } \\
\text { való részvételre, } \\
\text { - döntések elöké- } \\
\text { szítésében, meg- } \\
\text { alapozásában való } \\
\text { részvételre, } \\
\text { - a munkájukhoz } \\
\text { szükséges infor- } \\
\text { máció menedzse- } \\
\text { lésére, } \\
\text { - az önálló és fele- } \\
\text { lös munkavég- } \\
\text { zésre, } \\
\text { - csoportban vég- } \\
\text { zett munkára. } \\
\text { Rendelkeznek } \\
\text { kommunikációs és } \\
\text { együttmüködési }\end{array}$ & $\begin{array}{l}\text { való alkalmazá- } \\
\text { sára, } \\
\text { - idegen nyelven } \\
\text { és az informatika } \\
\text { segítségével is a } \\
\text { hazai és a nemzet- } \\
\text { közi üzleti környe- } \\
\text { zetben hatékonyan } \\
\text { kommunikálni, } \\
\text { - a környezeti vál- } \\
\text { tozásokhoz való } \\
\text { alkalmazkodásra, } \\
\text { az önálló karrier- } \\
\text { építésre tapaszta- } \\
\text { latainak értékelése } \\
\text { és folyamatos to- } \\
\text { vábbképzés útján; } \\
\text { az alapképzésben } \\
\text { megismert szakte- } \\
\text { rület gyakorlati } \\
\text { úton való kiszéle- } \\
\text { sítésére, } \\
\text { - önálló munka } \\
\text { végzésére a válla- } \\
\text { lati rendszer kü- } \\
\text { lönböző részterü- } \\
\text { letein, } \\
\text { - a gazdálkodó } \\
\text { szervezetek általá- } \\
\text { nos gazdálkodásá- } \\
\text { hoz és szervezésé- } \\
\text { hez kapcsolódó }\end{array}$ & $\begin{array}{l}\text { - önálló és cso- } \\
\text { portmunka végzé- } \\
\text { sére, } \\
\text { - a szervezet funk- } \\
\text { cionális területei- } \\
\text { vel és a marke- } \\
\text { tingszolgáltatókkal } \\
\text {, beszállítókkal, } \\
\text { partnerekkel való } \\
\text { együttmüködésre, } \\
\text { - reklám, eladás } \\
\text { ösztönzési, piac- } \\
\text { kutatási adatok } \\
\text { elemzésére, haté- } \\
\text { kony programok } \\
\text { összeállítására és } \\
\text { lebonyolításuk el- } \\
\text { lenőrzésére, } \\
\text { - a kereskedelmi } \\
\text { folyamatok elem- } \\
\text { zésére és tervezé- } \\
\text { sére, } \\
\text { - egyes logisztikai } \\
\text { feladatok ellátá- } \\
\text { sára, } \\
\text { - a kereskedelem } \\
\text { és marketing spe- } \\
\text { cifikus szoftverek } \\
\text { használatára, }\end{array}$ & $\begin{array}{l}\text { - önálló munka- } \\
\text { végzésre és cso- } \\
\text { portmunkára, } \\
\text { - közgazdasági } \\
\text { megfontolásokra } \\
\text { épülö, gazdasági } \\
\text { kalkuláción ala- } \\
\text { puló meggyőző } \\
\text { szakmai érvelésre, } \\
\text { informatikailag tá- } \\
\text { mogatott korszerü } \\
\text { elemzési módsze- } \\
\text { rek, tárgyalási és } \\
\text { prezentációs tech- } \\
\text { nikák alkalmazá- } \\
\text { sára, } \\
\text { - megbízható } \\
\text { munkavégzésre } \\
\text { multikulturális } \\
\text { környezetben, } \\
\text { - vezetői, tanács- } \\
\text { adói munka támo- } \\
\text { gatására, } \\
\text { - munkaerö-piaci } \\
\text { elemzések készíté- } \\
\text { sére, } \\
\text { emberierőforrás- } \\
\text { gazdálkodási } \\
\text { funkciók és érdek- }\end{array}$ & $\begin{array}{l}\text { - a menedzsment } \\
\text { funkciók gyakor- } \\
\text { lati alkalmazására, } \\
\text { - önálló és cso- } \\
\text { portmunkára, } \\
\text { - tárgyalási, pre- } \\
\text { zentációs és meg- } \\
\text { győzési technikák } \\
\text { alkalmazására, } \\
\text { - a problémák ön- } \\
\text { álló felismerésére, } \\
\text { a feladatok kijelö- } \\
\text { lésére, rangsorolá- } \\
\text { sára és megoldá- } \\
\text { sára. } \\
\text { Rendelkeznek ön- } \\
\text { álló probléma-fel- } \\
\text { ismerő és -meg- } \\
\text { oldó, továbbá in- } \\
\text { novációs készség- } \\
\text { gel, kritikai } \\
\text { elemző és javaslat- } \\
\text { tevő (kezdemé- } \\
\text { nyező) készséggel, } \\
\text { kapcsolatteremtö, } \\
\text { beilleszkedési és } \\
\text { együttműködési, } \\
\text { valamint szóbeli } \\
\text { és írásbeli kom- } \\
\text { munikációs kész- } \\
\text { séggel, toleranciá- }\end{array}$ & $\begin{array}{l}\text { a mérlegbeszá- } \\
\text { moló elkészíté- } \\
\text { sére, } \\
\text { - a vagyonra és } \\
\text { üzleti múködésre } \\
\text { vonatkozó beszá- } \\
\text { molók önálló ösz- } \\
\text { szeállítására, } \\
\text { elemzésére, } \\
\text { - adó-, illeték-, } \\
\text { vám-, jövedék-, } \\
\text { tb-kötelezettségek } \\
\text { meghatározására } \\
\text { és a bevallások el- } \\
\text { készítésére, } \\
\text { - gazdasági folya- } \\
\text { matok, szervezeti } \\
\text { események komp- } \\
\text { lex pénzügyi, } \\
\text { számviteli követ- } \\
\text { kezményeinek } \\
\text { meghatározására, } \\
\text { - számviteli poli- } \\
\text { tika, számviteli } \\
\text { szabályzatok ké- } \\
\text { szítésére, } \\
\text { - gazdálkodási, } \\
\text { likviditási és haté- } \\
\text { konysági követel- } \\
\text { mények összehan- } \\
\text { golására, }\end{array}$ & $\begin{array}{l}\text { ójú kommunikáci- } \\
\text { óra, nemzetközi } \\
\text { turizmussal kap- } \\
\text { csolatos feladatok } \\
\text { ellátására, vala- } \\
\text { mint az informati- } \\
\text { kai ismeretek al- } \\
\text { kalmazására, } \\
\text { - a turizmusban } \\
\text { specifikus tárgya- } \\
\text { lási, prezentációs, } \\
\text { információszerve- } \\
\text { zési és meggyö- } \\
\text { zési technikák al- } \\
\text { kalmazására, } \\
\text { - a szolgáltatások- } \\
\text { kal és az intenzív } \\
\text { ügyfélkapcsolattal } \\
\text { összefüggö prob- } \\
\text { lémák hatékony } \\
\text { kezelésére, külö- } \\
\text { nös figyelemmel } \\
\text { az interkulturális } \\
\text { konfliktusok lehe- } \\
\text { tőségeire, } \\
\text { - a turizmus fej- } \\
\text { lesztésével kap- } \\
\text { csolatos érdek- } \\
\text { konfliktusok keze- } \\
\text { lésére. }\end{array}$ \\
\hline
\end{tabular}




\begin{tabular}{|c|c|c|c|c|c|c|c|c|}
\hline $\begin{array}{c}\text { 1. Alkalmazott } \\
\text { közgazdaságtan }\end{array}$ & 2. Gazdaságelemzés & 3. Közszolgálati & $\begin{array}{l}\text { 4. Gazdálkodási és } \\
\text { menedzsment }\end{array}$ & $\begin{array}{l}\text { 5. Kereskedelem és } \\
\text { marketing }\end{array}$ & $\begin{array}{l}\text { 6. Emberi } \\
\text { erőforrások }\end{array}$ & $\begin{array}{l}\text { 7. Nemzetközi } \\
\text { gazdálkodás }\end{array}$ & $\begin{array}{l}\text { 8. Pénzügy és } \\
\text { számvitel }\end{array}$ & $\begin{array}{l}\text { 9. Turizmus- } \\
\text { vendéglátás }\end{array}$ \\
\hline & $\begin{array}{l}\text { zékenységgel, szó- } \\
\text { beli és írásbeli } \\
\text { kommunikációs } \\
\text { készséggel, tole- } \\
\text { rancia és szinergia } \\
\text { lehetősége felis- } \\
\text { merése képességé- } \\
\text { vel. }\end{array}$ & $\begin{array}{l}\text { készséggel, kriti- } \\
\text { kai érzékkel, fele- } \\
\text { lösségtudattal és } \\
\text { lojalitással, a tár- } \\
\text { sadalmi értékek } \\
\text { iránti elkötelezett- } \\
\text { séggel, a közpoli- } \\
\text { tika más szereplöi- } \\
\text { nek felfogása } \\
\text { iránti megbecsü- } \\
\text { léssel és empátiá- } \\
\text { val. }\end{array}$ & $\begin{array}{l}\text { munkakörökben } \\
\text { vezetői feladatok } \\
\text { ellátására. }\end{array}$ & $\begin{array}{l}\text { - jelentések, fel- } \\
\text { mérések elkészíté- } \\
\text { sére, szóbeli és } \\
\text { írásbeli kommuni- } \\
\text { kációra. }\end{array}$ & $\begin{array}{l}\text { egyeztetési folya- } \\
\text { matok vizsgála- } \\
\text { tára, } \\
\text { - a személyügyi, a } \\
\text { munkaerö-piaci és } \\
\text { az érdekképvise- } \\
\text { leti szervezetek- } \\
\text { ben szolgáltatási } \\
\text { feladatok ellátá- } \\
\text { sára, } \\
\text { - az } \\
\text { emberierőforrás- } \\
\text { fejlesztési és hasz- } \\
\text { nosítási döntéseket } \\
\text { előkészítő mód- } \\
\text { szerek és techni- } \\
\text { kák alkalmazására, } \\
\text { az elemzésekhez } \\
\text { szükséges infor- } \\
\text { mációk megszer- } \\
\text { zésére, feldolgozá- } \\
\text { sára, felmérések, } \\
\text { jelentések elkészí- } \\
\text { tésére. }\end{array}$ & $\begin{array}{l}\text { val, a másság elfo- } \\
\text { gadásának képes- } \\
\text { ségével. }\end{array}$ & $\begin{array}{l}\text { - önálló munka- } \\
\text { végzésre és cso- } \\
\text { portmunkára, } \\
\text { - tárgyalási és pre- } \\
\text { zentációs techni- } \\
\text { kák alkalmazására, } \\
\text { meggyőző szak- } \\
\text { mai érvelésre, kor- } \\
\text { szerú informatikai } \\
\text { eszközök haszná- } \\
\text { latára. }\end{array}$ & $\begin{array}{l}\text { Rendelkeznek az } \\
\text { adott szervezettí- } \\
\text { pusnak megfelelő } \\
\text { emberi és szociális } \\
\text { készségekkel, } \\
\text { együttmúködési } \\
\text { képességgel, képe- } \\
\text { sek önálló karrier- } \\
\text { építésre, a tapasz- } \\
\text { talati úton vagy } \\
\text { szervezett tovább- } \\
\text { képzés keretében } \\
\text { szerzett ismeretek } \\
\text { hasznosítására. }\end{array}$ \\
\hline
\end{tabular}




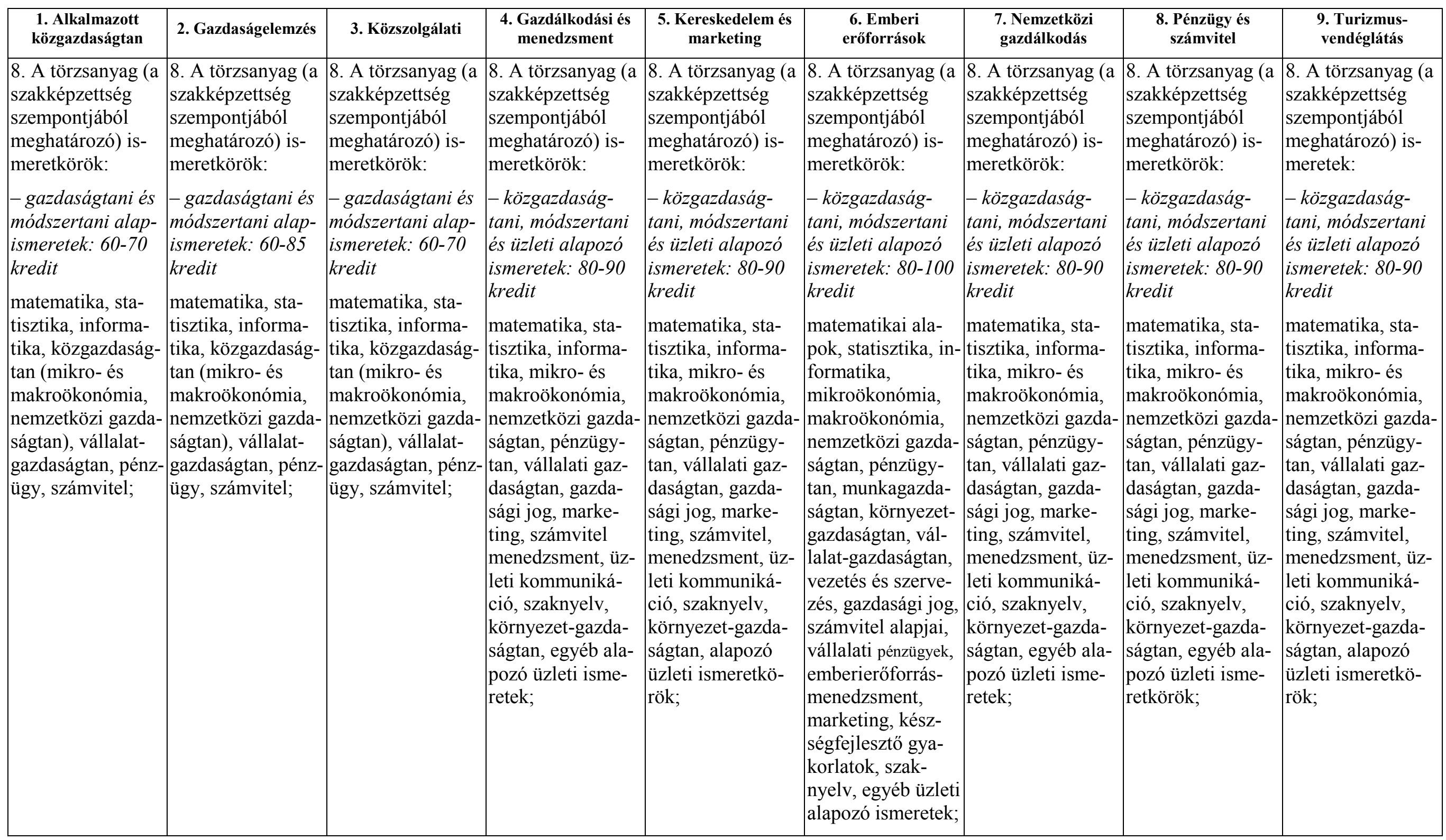




\begin{tabular}{|c|c|c|c|c|c|c|c|c|}
\hline $\begin{array}{l}\text { 1. Alkalmazott } \\
\text { közgazdaságtan }\end{array}$ & 2. Gazdaságelemzés & 3. Közszolgálati & $\begin{array}{l}\text { 4. Gazdálkodási és } \\
\text { menedzsment }\end{array}$ & $\begin{array}{l}\text { 5. Kereskedelem és } \\
\text { marketing }\end{array}$ & $\begin{array}{l}\text { 6. Emberi } \\
\text { eröforrások }\end{array}$ & $\begin{array}{l}\text { 7. Nemzetközi } \\
\text { gazdálkodás }\end{array}$ & $\begin{array}{l}\text { 8. Pénzügy és } \\
\text { számvitel }\end{array}$ & $\begin{array}{l}\text { 9. Turizmus- } \\
\text { vendéglátás }\end{array}$ \\
\hline \begin{tabular}{|l|} 
társadalomtudo- \\
mányi alapismere- \\
tek: $15-25$ kredit
\end{tabular} & $\begin{array}{l}\text { - társadalomtudo- } \\
\text { mányi alapismere- } \\
\text { tek: } 15-25 \text { kredit }\end{array}$ & $\begin{array}{l}\text { - társadalomtudo- } \\
\text { mányi alapismere- } \\
\text { tek: } 15-25 \text { kredit }\end{array}$ & $\begin{array}{l}\text { - társadalomtudo- } \\
\text { mányi alapismere- } \\
\text { tek: } 10-20 \text { kredit }\end{array}$ & $\begin{array}{l}\text { - társadalomtudo- } \\
\text { mányi alapismere- } \\
\text { tek: } 10-20 \text { kredit }\end{array}$ & \begin{tabular}{|l|} 
társadalomtudo- \\
mányi alapismere- \\
tek: $10-20$ kredit
\end{tabular} & $\begin{array}{l}\text { - társadalomtudo- } \\
\text { mányi alapismere- } \\
\text { tek: } 10-20 \text { kredit }\end{array}$ & $\begin{array}{l}\text { - társadalomtudo- } \\
\text { mányi alapismere- } \\
\text { tek: } 10-20 \text { kredit }\end{array}$ & $\begin{array}{l}\text { társadalomtudo- } \\
\text { mányi alapismere- } \\
\text { tek: 10-20 kredit }\end{array}$ \\
\hline $\begin{array}{l}\text { EU ismeretek, ál- } \\
\text { talános és gazda- } \\
\text { sági jogi ismere- } \\
\text { tek, gazdaságtörté- } \\
\text { net, szociológia, } \\
\text { pszichológia, filo- } \\
\text { zófia, szervezet- } \\
\text { és vezetéselmélet; }\end{array}$ & $\begin{array}{l}\text { EU ismeretek, ál- } \\
\text { talános és gazda- } \\
\text { sági jogi ismere- } \\
\text { tek, gazdaságtörté- } \\
\text { net, szociológia, } \\
\text { pszichológia, filo- } \\
\text { zófia, szervezet- } \\
\text { és vezetéselmélet; }\end{array}$ & $\begin{array}{l}\text { EU ismeretek, ál- } \\
\text { talános és gazda- } \\
\text { sági jogi ismere- } \\
\text { tek, gazdaságtörté- } \\
\text { net, szociológia, } \\
\text { pszichológia, filo- } \\
\text { zófia, szervezet- } \\
\text { és vezetéselmélet; }\end{array}$ & $\begin{array}{l}\text { EU, általános és } \\
\text { gazdasági jogi is- } \\
\text { meretek, gazda- } \\
\text { ságtörténet, szoci- } \\
\text { ológia, pszicholó- } \\
\text { gia, filozófia; }\end{array}$ & $\begin{array}{l}\text { EU, általános és } \\
\text { gazdasági jogi is- } \\
\text { meretek, gazda- } \\
\text { ságtörténet, szoci- } \\
\text { ológia, pszicholó- } \\
\text { gia, filozófia; }\end{array}$ & $\begin{array}{l}\text { filozófia, szocioló- } \\
\text { gia, pszichológia, } \\
\text { politológia, jog, } \\
\text { gazdaságtörténet, } \\
\text { demográfia, gaz- } \\
\text { daságpolitika, eu- } \\
\text { rópai uniós isme- } \\
\text { retek, egyéb szak- } \\
\text { mai és társadalom- } \\
\text { tudományi ismere- } \\
\text { tek; }\end{array}$ & $\begin{array}{l}\text { EU, általános és } \\
\text { gazdasági jogi is- } \\
\text { meretek, gazda- } \\
\text { ságtörténet, szoci- } \\
\text { ológia, pszicholó- } \\
\text { gia, filozófia, szer- } \\
\text { vezet- és vezetés- } \\
\text { elmélet; }\end{array}$ & $\begin{array}{l}\text { EU, általános és } \\
\text { gazdasági jogi is- } \\
\text { meretek, gazda- } \\
\text { ságtörténet, szoci- } \\
\text { ológia, pszicholó- } \\
\text { gia, filozófia; }\end{array}$ & \begin{tabular}{|l} 
EU, általános és \\
gazdasági jogi is- \\
meretek, gazda- \\
ságtörténet, szoci- \\
ológia, pszicholó- \\
gia, filozófia;
\end{tabular} \\
\hline $\begin{array}{l}\text { - szakmai törzs- } \\
\text { anyag: } 80-100 \\
\text { kredit }\end{array}$ & $\begin{array}{l}\text { - szakmai törzs- } \\
\text { anyag: } 80-90 \text { kre- } \\
\text { dit }\end{array}$ & $\begin{array}{l}\text { - szakmai törzs- } \\
\text { anyag: } 80-100 \\
\text { kredit }\end{array}$ & $\begin{array}{l}\text { - szakmai törzs- } \\
\text { anyag: } 70-90 \text { kre- } \\
\text { dit }\end{array}$ & $\begin{array}{l}\text { - szakmai törzs- } \\
\text { anyag: } 70-90 \text { kre- } \\
\text { dit }\end{array}$ & \begin{tabular}{|l|} 
- szakmai törzs- \\
anyag: $70-90$ kre- \\
dit
\end{tabular} & $\begin{array}{l}\text { - szakmai törzs- } \\
\text { anyag: } 70-90 \text { kre- } \\
\text { dit }\end{array}$ & \begin{tabular}{|l} 
- szakmai törzs- \\
anyag: $70-90$ kre- \\
dit
\end{tabular} & \begin{tabular}{|l|} 
- szakmai törzs- \\
anyag: $70-90$ kre- \\
dit
\end{tabular} \\
\hline \begin{tabular}{|l|} 
gazdaságelméleti, \\
gazdaságstatiszti- \\
kai, pénzügyi, el- \\
mélettörténeti, \\
gazdaság modelle- \\
zési, gazdaságpoli- \\
tikai, ágazati és \\
funkcionális gaz- \\
daságtani, közös- \\
ségi gazdaságtani, \\
világ- és Európa- \\
gazdaságtani, kör- \\
nyezet gazdaság- \\
tani, közpolitikai \\
ismeretek, továbbá
\end{tabular} & $\begin{array}{l}\text { gazdaságelméleti, } \\
\text { elmélettörténeti, } \\
\text { matematikai köz- } \\
\text { gazdaságtani, ope- } \\
\text { rációkutatási, sta- } \\
\text { tisztikai, pénzügyi, } \\
\text { alkalmazott mo- } \\
\text { dellezési, gazda- } \\
\text { ságpolitikai isme- } \\
\text { retek. }\end{array}$ & $\begin{array}{l}\text { közigazgatási és } \\
\text { jogági ismeretkör } \\
\text { (közintézményjogi } \\
\text { alapismeretek, al- } \\
\text { kotmánytan, gaz- } \\
\text { dasági jogi } \\
\text { (civilisztikai) alap- } \\
\text { ismeretek); köz- } \\
\text { menedzsment is- } \\
\text { meretkör (a köz- } \\
\text { szektor és a köz- } \\
\text { szolgáltatások mo- } \\
\text { dernizációja, köz- } \\
\text { célú szervezetek }\end{array}$ & $\begin{array}{l}\text { vállalati pénz- } \\
\text { ügyek, számviteli } \\
\text { elemzés, emberi } \\
\text { erőforrás gazdál- } \\
\text { kodás, marketing } \\
\text { menedzsment, ve- } \\
\text { zetés és szervezés, } \\
\text { értékteremtő fo- } \\
\text { lyamatok me- } \\
\text { nedzsmentje, dön- } \\
\text { téselmélet és mód- } \\
\text { szertan, kontroll- } \\
\text { ing, üzleti etika, } \\
\text { stratégiai tervezés, }\end{array}$ & $\begin{array}{l}\text { vállalatirányítás, } \\
\text { kereskedelem gaz- } \\
\text { daságtana, marke- } \\
\text { ting menedzsment, } \\
\text { szervezeti maga- } \\
\text { tartás, vállalati } \\
\text { pénzügyek, mar- } \\
\text { ketingkutatás, kül- } \\
\text { kereskedelmi tech- } \\
\text { nikák, marketing- } \\
\text { kommunikáció, lo- } \\
\text { gisztika, média } \\
\text { gazdaságtan, to- } \\
\text { vábbá választható }\end{array}$ & \begin{tabular}{|l|} 
munkaerö-piaci \\
intézmények és \\
politikák, szerve- \\
zet- és munkaszo- \\
ciológia, munka- \\
helyi és \\
munkaerőpiaci \\
képzés, munka- \\
ügyi kapcsolatok \\
rendszere, munka- \\
jog, kompetencia- \\
és ösztönzésme- \\
nedzsment, üzleti \\
kommunikáció és \\
tárgyalástechnika,
\end{tabular} & $\begin{array}{l}\text { nemzetközi keres- } \\
\text { kedelemi és gaz- } \\
\text { dasági intézmé- } \\
\text { nyek, világgazda- } \\
\text { sági folyamatok és } \\
\text { régiók, külgazda- } \\
\text { sági politika, } \\
\text { elemzés és piacfej- } \\
\text { lesztés, nemzet- } \\
\text { közi pénzügyek, } \\
\text { nemzetközi ügyle- } \\
\text { tek, nemzetközi } \\
\text { marketing, inter- } \\
\text { kulturális me- } \\
\text { nedzsment, EU- }\end{array}$ & \begin{tabular}{|l|} 
pénzügyek, jog, \\
pénzügyi számítá- \\
sok és pénzügyi \\
piacok, adózási is- \\
meretek, vállalat- \\
értékelés, pénz- \\
ügyi számvitel, \\
vezetői számvitel \\
alapjai, elemzés- \\
ellenőrzés mód- \\
szertana, üzleti \\
tervezés, a pénz- \\
ügyi és számviteli \\
informatika, sajá-
\end{tabular} & \begin{tabular}{|l|} 
a turizmus rend- \\
szere, vendéglátás, \\
szállásadás, uta- \\
zásszervezés, tu- \\
risztikai erőforrá- \\
sok, a turizmus \\
közigazgatási, \\
szakigazgatási, ön- \\
kormányzati vo- \\
natkozásai, \\
turizmus marke- \\
ting, turisztikai \\
termékek, turiszti- \\
kai vállalkozások,
\end{tabular} \\
\hline
\end{tabular}




\begin{tabular}{|c|c|c|c|c|c|c|c|c|}
\hline $\begin{array}{l}\text { 1. Alkalmazott } \\
\text { közgazdaságtan }\end{array}$ & 2. Gazdaságelemzés & 3. Közszolgálati & $\begin{array}{l}\text { 4. Gazdálkodási és } \\
\text { menedzsment }\end{array}$ & $\begin{array}{l}\text { 5. Kereskedelem és } \\
\text { marketing }\end{array}$ & $\begin{array}{c}\text { 6. Emberi } \\
\text { eröforrások }\end{array}$ & $\begin{array}{l}\text { 7. Nemzetközi } \\
\text { gazdálkodás }\end{array}$ & $\begin{array}{l}\text { 8. Pénzügy és } \\
\text { számvitel }\end{array}$ & $\begin{array}{l}\text { 9. Turizmus- } \\
\text { vendéglátás }\end{array}$ \\
\hline $\begin{array}{l}\text { differenciált szak- } \\
\text { mai ismeretek. }\end{array}$ & & $\begin{array}{l}\text { vezetése és straté- } \\
\text { giai tervezése); ál- } \\
\text { lamháztartás-költ- } \\
\text { ségvetés ismeret- } \\
\text { kör (költségvetési } \\
\text { politika, költség- } \\
\text { vetési szervek } \\
\text { számvitele); köz- } \\
\text { politikai ismeret- } \\
\text { kör (társadalom- } \\
\text { politika, etika és } \\
\text { felelősség, közpo- } \\
\text { litika elemzés); to- } \\
\text { vábbá differenciált } \\
\text { szakmai ismere- } \\
\text { tek. }\end{array}$ & $\begin{array}{l}\text { továbbá választ- } \\
\text { ható szakirányok, } \\
\text { amelyek a szakmai } \\
\text { törzsanyaghoz } \\
\text { kapcsolódó, a } \\
\text { szakképzettség ré- } \\
\text { szeként megsze- } \\
\text { rezhető speciális } \\
\text { tudást adó ismere- } \\
\text { tek. }\end{array}$ & $\begin{array}{l}\text { szakirányok, ame- } \\
\text { lyek a szak törzs- } \\
\text { anyagához, a ke- } \\
\text { reskedelem vagy } \\
\text { marketing szak- } \\
\text { anyagához kap- } \\
\text { csolódó, a szak- } \\
\text { képzettség része- } \\
\text { ként megszerez- } \\
\text { hető speciális tu- } \\
\text { dást biztosító is- } \\
\text { meretek. }\end{array}$ & $\begin{array}{l}\text { személyügyi tevé- } \\
\text { kenység, személy- } \\
\text { ügyi informatika, } \\
\text { személyügyi kont- } \\
\text { rolling, szervezeti } \\
\text { magatartás, szoci- } \\
\text { álpszichológia, } \\
\text { szervezeti kom- } \\
\text { munikáció, terület- } \\
\text { fejlesztés, oktatás- } \\
\text { politika, } \\
\text { emberierőforrás- } \\
\text { gazdálkodási eset- } \\
\text { tanulmányok, } \\
\text { munkavédelem és } \\
\text { ergonómia, regio- } \\
\text { nális munkaerö- } \\
\text { gazdálkodás, pro- } \\
\text { jektvezetés, operá- } \\
\text { ciókutatás, to- } \\
\text { vábbá specializá- } \\
\text { ciók, szakirányok, } \\
\text { amelyek a szak } \\
\text { törzsanyagához, } \\
\text { kötelező és vá- } \\
\text { lasztható tárgyai- } \\
\text { hoz kapcsolódó } \\
\text { speciális szakmai } \\
\text { ismeretek elmélyí- } \\
\text { tését teszik lehe- } \\
\text { tővé. }\end{array}$ & $\begin{array}{l}\text { közösségi politi- } \\
\text { kák, nemzetközi } \\
\text { tárgyalási techni- } \\
\text { kák, nemzetközi } \\
\text { etikett, protokoll, } \\
\text { továbbá választ- } \\
\text { ható szakirányok, } \\
\text { amelyek a szakmai } \\
\text { törzsanyaghoz } \\
\text { kapcsolódó, a } \\
\text { szakképzettség ré- } \\
\text { szeként megsze- } \\
\text { rezhető speciális } \\
\text { tudást biztosító is- } \\
\text { meretek. }\end{array}$ & $\begin{array}{l}\text { tos számviteli ese- } \\
\text { tek, elszámolására } \\
\text { vonatkozó ismere- } \\
\text { tek, továbbá vá- } \\
\text { lasztható szakirá- } \\
\text { nyok, amelyek a } \\
\text { szak törzsanyagá- } \\
\text { hoz, a pénzügyi } \\
\text { vagy számviteli } \\
\text { szakágakhoz kap- } \\
\text { csolódó, a szak- } \\
\text { képzettség része- } \\
\text { ként megszerez- } \\
\text { hető speciális tu- } \\
\text { dást biztosító is- } \\
\text { meretek. }\end{array}$ & \begin{tabular}{|l|} 
vendéglátás szer- \\
vezés, vezetés, \\
nemzetközi gazda- \\
sági kapcsolatok, \\
továbbá választ- \\
ható szakirányok, \\
amelyek a szakmai \\
törzsanyaghoz, a \\
turizmus vagy a \\
vendéglátás isme- \\
retköreihez kap- \\
csolódó, a szak- \\
képzettség része- \\
ként megszerez- \\
hető speciális tu- \\
dást biztosító is- \\
meretek.
\end{tabular} \\
\hline
\end{tabular}




\begin{tabular}{|c|c|c|c|c|c|c|c|c|}
\hline $\begin{array}{c}\text { 1. Alkalmazott } \\
\text { közgazdaságtan }\end{array}$ & 2. Gazdaságelemzés & 3. Közszolgálati & $\begin{array}{l}\text { 4. Gazdálkodási és } \\
\text { menedzsment }\end{array}$ & $\begin{array}{l}\text { 5. Kereskedelem és } \\
\text { marketing }\end{array}$ & $\begin{array}{c}\text { 6. Emberi } \\
\text { eröforrások }\end{array}$ & $\begin{array}{l}\text { 7. Nemzetközi } \\
\text { gazdálkodás }\end{array}$ & $\begin{array}{l}\text { 8. Pénzügy és } \\
\text { számvitel }\end{array}$ & $\begin{array}{l}\text { 9. Turizmus- } \\
\text { vendéglátás }\end{array}$ \\
\hline & & & $\begin{array}{l}\text { 9. Szakmai gya- } \\
\text { korlat: } \\
\text { Az alapképzési } \\
\text { szakon egy félévig } \\
\text { tartó szakmai gya- } \\
\text { korlatot kell szer- } \\
\text { vezni. }\end{array}$ & $\begin{array}{l}\text { 9. Szakmai gya- } \\
\text { korlat: } \\
\text { Az alapképzési } \\
\text { szakon egy félévig } \\
\text { tartó szakmai gya- } \\
\text { korlatot kell szer- } \\
\text { vezni. }\end{array}$ & $\begin{array}{l}\text { 9. Szakmai gya- } \\
\text { korlat: } \\
\text { A szakmai gyakor- } \\
\text { lat az egyes isme- } \\
\text { retkörökhöz kap- } \\
\text { csolódó gyakorlati } \\
\text { foglalkozásokon } \\
\text { szerezhető meg. }\end{array}$ & $\begin{array}{l}\text { 9. Szakmai gya- } \\
\text { korlat: } \\
\text { Az alapképzési } \\
\text { szakon egy félévig } \\
\text { tartó szakmai gya- } \\
\text { korlatot kell szer- } \\
\text { vezni. }\end{array}$ & $\begin{array}{l}\text { 9. Szakmai gya- } \\
\text { korlat: } \\
\text { Az alapképzési } \\
\text { szakon egy félévig } \\
\text { tartó szakmai gya- } \\
\text { korlatot kell szer- } \\
\text { vezni. }\end{array}$ & $\begin{array}{l}\text { 9. Szakmai gya- } \\
\text { korlat: } \\
\text { Az alapképzési } \\
\text { szakon egy félévig } \\
\text { tartó szakmai gya- } \\
\text { korlatot kell szer- } \\
\text { vezni. }\end{array}$ \\
\hline $\begin{array}{l}\text { 9. Idegennyelvi } \\
\text { követelmények: }\end{array}$ & $\begin{array}{l}\text { 9. Idegennyelvi } \\
\text { követelmények: }\end{array}$ & $\begin{array}{l}\text { 9. Idegennyelvi } \\
\text { követelmények: }\end{array}$ & $\begin{array}{l}\text { 10. Idegennyelvi } \\
\text { követelmények: }\end{array}$ & $\begin{array}{l}\text { 10. Idegennyelvi } \\
\text { követelmények: }\end{array}$ & $\begin{array}{l}\text { 10. Idegennyelvi } \\
\text { követelmények: }\end{array}$ & $\begin{array}{l}\text { 10. Idegennyelvi } \\
\text { követelmények: }\end{array}$ & $\begin{array}{l}\text { 10. Idegennyelvi } \\
\text { követelmények: }\end{array}$ & $\begin{array}{l}\text { 10. Idegennyelvi } \\
\text { követelmények }\end{array}$ \\
\hline $\begin{array}{l}\text { Az alapfokozat } \\
\text { megszerzéséhez } \\
\text { legalább egy ide- } \\
\text { gen nyelvből álla- } \\
\text { milag elismert kö- } \\
\text { zépfokú (B2) } \\
\text { komplex típusú, a } \\
\text { képzési területnek } \\
\text { megfelelö szak- } \\
\text { nyelvi vagy álla- } \\
\text { milag elismert fel- } \\
\text { sőfokú (C1) } \\
\text { komplex típusú ál- } \\
\text { talános nyelv- } \\
\text { vizsga vagy ezek- } \\
\text { kel egyenértékú } \\
\text { érettségi bizonyít- } \\
\text { vány vagy oklevél } \\
\text { szükséges. }\end{array}$ & \begin{tabular}{|l} 
Azz alapfokozat \\
megszerzéséhez \\
legalább egy ide- \\
gen nyelvből álla- \\
milag elismert kö- \\
zépfokú (B2) \\
komplex típusú, a \\
képzési területnek \\
megfelelő szak- \\
nyelvi vagy álla- \\
milag elismert fel- \\
sőfokú (C1) \\
komplex típusú ál- \\
talános nyelv- \\
vizsga vagy ezek- \\
kel egyenértékủ \\
érettségi bizonyít- \\
vány vagy oklevél \\
szükséges.
\end{tabular} & $\begin{array}{l}\text { Az alapfokozat } \\
\text { megszerzéséhez } \\
\text { legalább egy ide- } \\
\text { gen nyelvből álla- } \\
\text { milag elismert kö- } \\
\text { zépfokú (B2) } \\
\text { komplex típusú, a } \\
\text { képzési területnek } \\
\text { megfelelö szak- } \\
\text { nyelvi vagy álla- } \\
\text { milag elismert fel- } \\
\text { sőfokú (C1) } \\
\text { komplex típusú ál- } \\
\text { talános nyelv- } \\
\text { vizsga vagy ezek- } \\
\text { kel egyenértékủ } \\
\text { érettségi bizonyít- } \\
\text { vány vagy oklevél } \\
\text { szükséges. }\end{array}$ & $\begin{array}{l}\text { Az alapfokozat } \\
\text { megszerzéséhez } \\
\text { legalább egy ide- } \\
\text { gen nyelvből álla- } \\
\text { milag elismert kö- } \\
\text { zépfokú (B2) } \\
\text { komplex típusú, a } \\
\text { képzési területnek } \\
\text { megfelelő szak- } \\
\text { nyelvi vagy álla- } \\
\text { milag elismert fel- } \\
\text { sőfokú (C1) } \\
\text { komplex típusú ál- } \\
\text { talános nyelv- } \\
\text { vizsga vagy ezek- } \\
\text { kel egyenértékủ } \\
\text { érettségi bizonyít- } \\
\text { vány vagy oklevél } \\
\text { szükséges. }\end{array}$ & $\begin{array}{l}\text { Az alapfokozat } \\
\text { megszerzéséhez } \\
\text { legalább egy ide- } \\
\text { gen nyelvböl álla- } \\
\text { milag elismert kö- } \\
\text { zépfokú (B2) } \\
\text { komplex típusú, a } \\
\text { képzési területnek } \\
\text { megfelelő szak- } \\
\text { nyelvi vagy álla- } \\
\text { milag elismert fel- } \\
\text { sőfokú (C1) } \\
\text { komplex típusú ál- } \\
\text { talános nyelv- } \\
\text { vizsga vagy ezek- } \\
\text { kel egyenértékü } \\
\text { érettségi bizonyít- } \\
\text { vány vagy oklevél } \\
\text { szükséges. }\end{array}$ & \begin{tabular}{|l} 
Az alapfokozat \\
megszerzéséhez \\
legalább egy ide- \\
gen nyelvből álla- \\
milag elismert kö- \\
zépfokú (B2) \\
komplex típusú, a \\
képzési területnek \\
megfelelő szak- \\
nyelvi vagy álla- \\
milag elismert fel- \\
sőfokú (C1) \\
komplex típusú ál- \\
talános nyelv- \\
vizsga vagy ezek- \\
kel egyenértékú \\
érettségi bizonyít- \\
vány vagy oklevél \\
szükséges.
\end{tabular} & \begin{tabular}{|l} 
Az alapfokozat \\
megszerzéséhez \\
legalább két ide- \\
gen nyelvből álla- \\
milag elismert kö- \\
zépfokú (B2) \\
komplex típusú, a \\
képzési területnek \\
megfelelö szak- \\
nyelvi nyelvvizsga \\
- amelyek közül \\
az egyik államilag \\
elismert felsőfokú \\
(C1) komplex tí- \\
pusú általános \\
nyelvvizsgával ki- \\
váltható - vagy \\
ezekkel egyenér- \\
tékủ érettségi bi- \\
zonyítvány vagy \\
oklevél szükséges.
\end{tabular} & $\begin{array}{l}\text { Az alapfokozat } \\
\text { megszerzéséhez } \\
\text { legalább egy ide- } \\
\text { gen nyelvből álla- } \\
\text { milag elismert kö- } \\
\text { zépfokú (B2) } \\
\text { komplex típusú, a } \\
\text { képzési területnek } \\
\text { megfelelö szak- } \\
\text { nyelvi vagy álla- } \\
\text { milag elismert fel- } \\
\text { sőfokú (C1) } \\
\text { komplex típusú ál- } \\
\text { talános nyelv- } \\
\text { vizsga vagy ezek- } \\
\text { kel egyenértékú } \\
\text { érettségi bizonyít- } \\
\text { vány vagy oklevél } \\
\text { szükséges. }\end{array}$ & $\begin{array}{l}\text { Az alapfokozat } \\
\text { megszerzéséhez } \\
\text { legalább két ide- } \\
\text { gen nyelvből álla- } \\
\text { milag elismert kö- } \\
\text { zépfokú (B2) } \\
\text { komplex típusú, a } \\
\text { képzési területnek } \\
\text { megfelelö szak- } \\
\text { nyelvi nyelvvizsga } \\
\text { - amelyek közül } \\
\text { az egyik államilag } \\
\text { elismert felsőfokú } \\
\text { (C1) komplex tí- } \\
\text { pusú általános } \\
\text { nyelvvizsgával ki- } \\
\text { váltható - vagy } \\
\text { ezekkel egyenér- } \\
\text { tékủ érettségi bi- } \\
\text { zonyítvány vagy } \\
\text { oklevél szükséges. }\end{array}$ \\
\hline
\end{tabular}


DOI: $10.14267 /$ phd.2014081 
DOI: $10.14267 /$ phd.2014081

\section{4. melléklet Gazdaságinformatika ontológia}

[Gábor András közlése alapján, Corvinno Technológia Transzfer Központ]

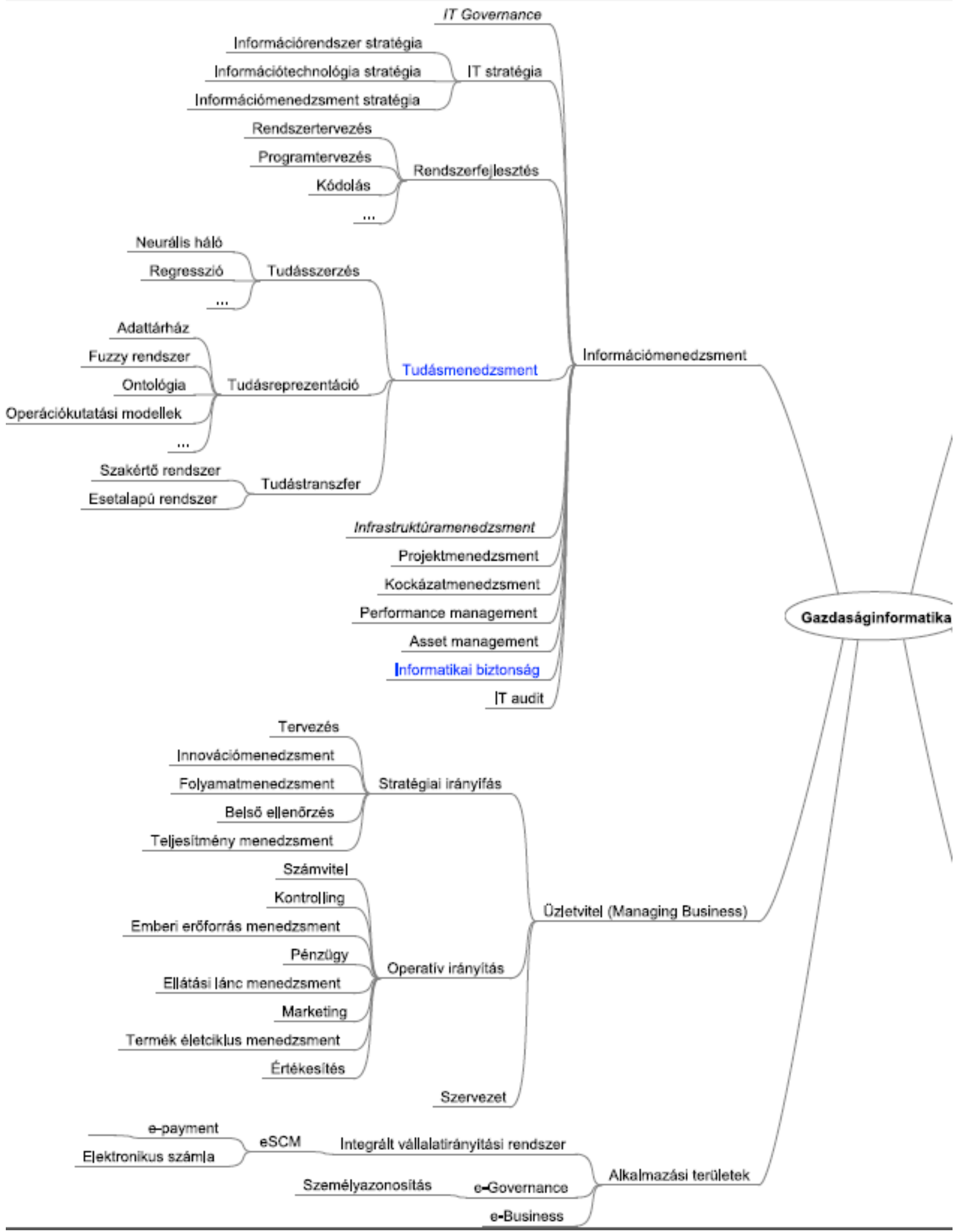


DOI: 10.14267/phd.2014081

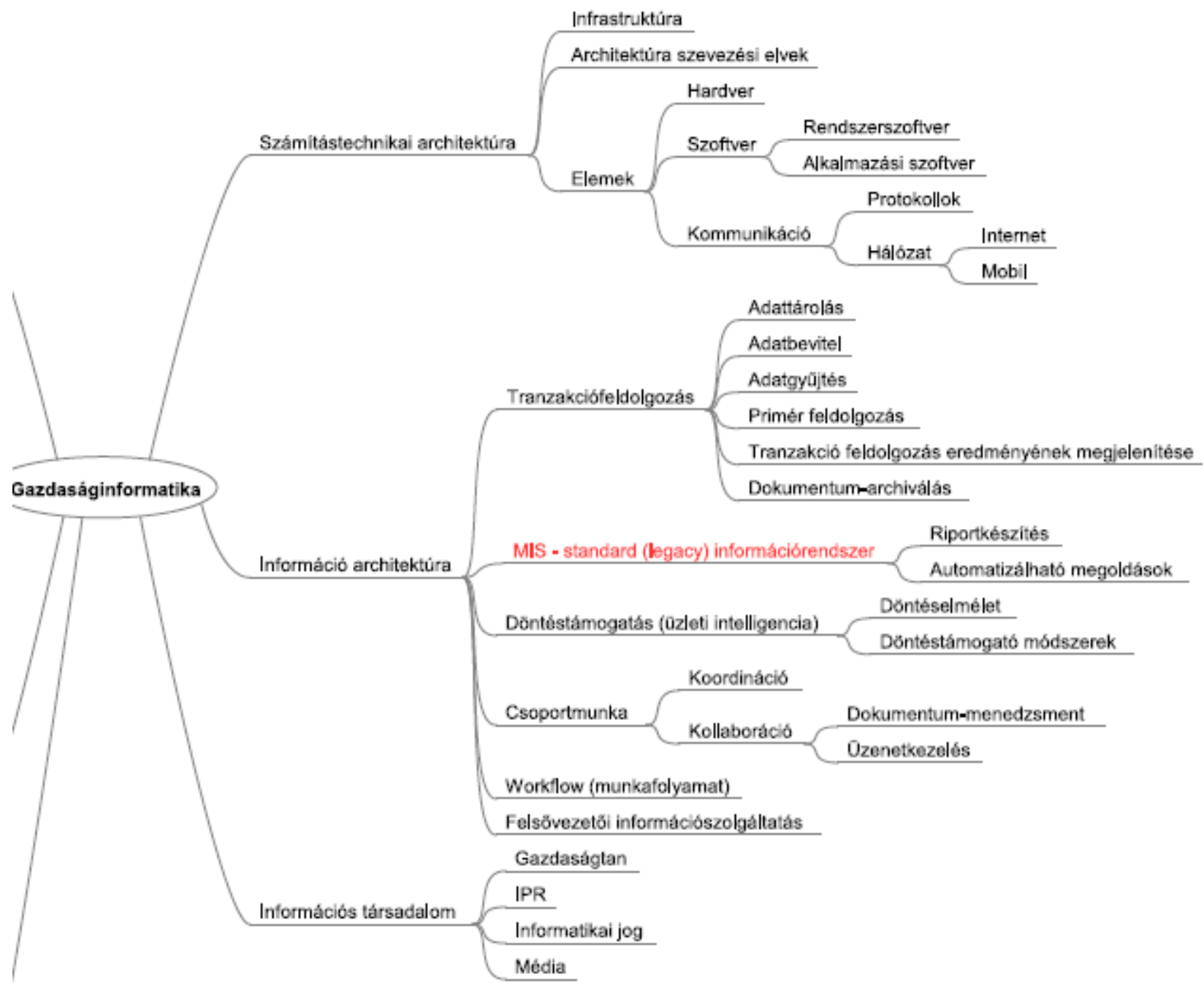


DOI: $10.14267 /$ phd.2014081

\section{5. melléklet A szövegszerkesztési és táblázatkezelési eszközök kódolása}

\begin{tabular}{|c|c|c|}
\hline \multicolumn{3}{|c|}{ SZÖVEGSZERKESZTÉS } \\
\hline KóD & MEGNEVEZÉS & ÁTLAG \\
\hline \multicolumn{3}{|c|}{ ECDL } \\
\hline $\mathrm{E} 02$ & szöveg írása, módosítása & 1,94 \\
\hline E03 & keresés, csere & 1,72 \\
\hline E04 & elválasztás & 1,25 \\
\hline E05 & helyesírás ellenörzés & 1,7 \\
\hline E06 & nézetváltás & 1,73 \\
\hline E07 & karakterformázások & 1,97 \\
\hline E08 & térköz & 1,79 \\
\hline E09 & tabulátor & 1,65 \\
\hline$\overline{E 12}$ & oldalbeállítások & 1,76 \\
\hline E13 & $\begin{array}{l}\text { élőfej és élőláb, oldalszá- } \\
\text { mozás }\end{array}$ & 1,68 \\
\hline$\overline{\mathrm{P} 01}$ & többszintü felsorolás & 1,65 \\
\hline P08 & táblázat a szövegben & 1,64 \\
\hline P20 & $\begin{array}{l}\text { speciális nyomtatási beállí- } \\
\text { tások }\end{array}$ & 1,54 \\
\hline \multicolumn{3}{|c|}{ HOSSZÚ DOKUMENTUM } \\
\hline $\mathrm{P} 02$ & lábjegyzet & 1,36 \\
\hline$\overline{\mathrm{P} 05}$ & címsorok & 1,09 \\
\hline P06 & tartalomjegyzék & 0,97 \\
\hline P09 & rajz vagy folyamatábra & 1,18 \\
\hline$\overline{\mathrm{P} 12}$ & szakaszok & 1,36 \\
\hline P13 & hasábok & 1,11 \\
\hline P14 & mezők szerkesztése & 1,11 \\
\hline \multicolumn{3}{|c|}{ DESIGN } \\
\hline E01 & Word sablonok & 0,96 \\
\hline E10 & stíluskészletek & 1,2 \\
\hline $\mathrm{P} 03$ & szövegdobozok & 1,1 \\
\hline P04 & szegélyezés & 1,36 \\
\hline P10 & szöveg körbefuttatása & 1,07 \\
\hline P11 & egyenletszerkesztő & 0,91 \\
\hline \multicolumn{3}{|c|}{ EXTRA } \\
\hline E11 & körlevél & 0,82 \\
\hline P07 & saját stílus & 0,72 \\
\hline$\overline{\mathrm{P} 15}$ & kereszthivatkozás & 0,72 \\
\hline P16 & tárgymutató & 0,65 \\
\hline P18 & ürlap & 0,48 \\
\hline$\overline{P 19}$ & makró & 0,44 \\
\hline P17 & jelszavas védelem & 0,83 \\
\hline
\end{tabular}

\begin{tabular}{|c|c|c|}
\hline \multicolumn{3}{|c|}{ TÁBLÁZATKEZELÉS } \\
\hline KóD & MEGNEVEZÉs & ÁtLAG \\
\hline \multicolumn{3}{|c|}{ ECDL } \\
\hline E02 & adatbevitel, módosítás & 1,86 \\
\hline E03 & számformátumok & 1,9 \\
\hline E04 & dátumformátumok & 1,79 \\
\hline E06 & sorba rendezés & 1,78 \\
\hline E07 & másolás, mozgatás, kitöltés & 1,89 \\
\hline E08 & sorok, oszlopok rögzítése & 1,62 \\
\hline E09 & munkalap müveletek & 1,86 \\
\hline E10 & cellaformázás & 1,95 \\
\hline E17 & nyomtatási beállítások, élőfej, élőláb & 1,75 \\
\hline P01 & egyéni számformátumok & 1,38 \\
\hline P03 & irányított beillesztés & 1,74 \\
\hline P05 & munkalapok elrejtése, felfedése & 1,46 \\
\hline P19 & autoszürö & 1,59 \\
\hline \multicolumn{3}{|c|}{ ALAP FÜGGVÉNYEK } \\
\hline E05 & gyorsbillentyük & 1,33 \\
\hline E13 & relatív és abszolút cellahivatkozások & 1,22 \\
\hline E14 & hibaüzenetek értelmezése & 1,16 \\
\hline E15 & HA függvény & 1,16 \\
\hline E16 & DARABTELI függvény & 0,93 \\
\hline P08 & képletellenőrzés & 1,23 \\
\hline P10 & statisztikai függvények & 1,1 \\
\hline P14 & FKERES, VKERES & 1,1 \\
\hline $\mathrm{P} 20$ & részösszeg & 1,22 \\
\hline \multicolumn{3}{|c|}{ MEGJELENÍTÉS } \\
\hline E01 & Excel sablonok & 0,78 \\
\hline E11 & kör, oszlop diagram & 1,29 \\
\hline E12 & más típusú diagram & 1,01 \\
\hline P02 & cellatartomány elnevezése & 1,27 \\
\hline $\mathrm{P} 04$ & szöveges fájl importálása & 1,23 \\
\hline P06 & feltételes formázás & 1,07 \\
\hline P07 & diagram szerkezetének változtatása, trendvonal & 1,13 \\
\hline P21 & kimutatás & 1,28 \\
\hline $\mathrm{P} 30$ & minden oldalon ismétlődő sorok, oszlopok & 1,15 \\
\hline \multicolumn{3}{|c|}{ HALADÓ FÜGGVÉNYEK } \\
\hline P09 & dátum és időfüggvények & 0,93 \\
\hline P11 & GYAKORISÁG & 0,56 \\
\hline P12 & szövegfüggvények & 0,79 \\
\hline P13 & pénzügyi függvények & 0,81 \\
\hline P16 & logikai függvények & 0,83 \\
\hline P18 & függvények egymásba ágyazása & 0,74 \\
\hline P22 & adattáblák & 0,48 \\
\hline P24 & célértékkeresés & 0,41 \\
\hline $\mathrm{P} 27$ & makró futtatás & 0,58 \\
\hline P29 & jelszóvédelem & 0,89 \\
\hline P31 & INDEX HOL.VAN & 0,49 \\
\hline \multicolumn{3}{|c|}{ EXTRA } \\
\hline P15 & mátrixfüggvények & 0,28 \\
\hline P17 & adatbázis függvények & 0,62 \\
\hline $\mathrm{P} 23$ & esetvizsgálat & 0,28 \\
\hline $\mathrm{P} 25$ & solver & 0,12 \\
\hline $\mathrm{P} 26$ & makró rögzítés & 0,41 \\
\hline $\mathrm{P} 28$ & makró írás & 0,26 \\
\hline P32 & cellaérvény & 0,47 \\
\hline
\end{tabular}


DOI: $10.14267 /$ phd.2014081 


\section{HIVATKOZÁSOK JEGYZÉKE}

1229/2012. (VII. 6.) Korm. határozat a Magyar Képesítési Keretrendszer bevezetéséhez kapcsolódó feladatokról, valamint az Országos Képesítési Keretrendszer létrehozásáról és bevezetéséről szóló 1004/2011. (I. 14.) Korm. határozat módosításáról (http://jogszabalykereso.mhk.hu/cgi bin/njt doc.cgi?docid=151757.605035 utolsó megtekintés: 2013. 08. 28.)

Adam, S. (2004): Using Learning Outcomes: A consideration of the nature, role, applicationand implications for European education of employing learning outcomes at the local,national and international levels. Report on United Kingdom Bologna Seminar, July 2004,Herriot-Watt University, Edinburgh, Scotland.

Adam, S. (2008): Learning outcomes current developments in Europe: update on the issues and applications of learning outcomes associated with the Bologna process. Bologna Seminar: Learning outcomes based higher education: the Scottish experience. February 2008, Heriot-Watt University, Edinburgh, Scotland. (www.ond.vlaanderen.be/hogeronderwijs/bologna/BolognaSeminars/documents/Edin burgh/Edinburgh_Feb08_Adams.pdf utolsó megtekintés: 2013. augusztus 18.)

Allan, J. (1996): Learning outcomes in higher education, Studies in Higher Education, $21(10)$ p. $93-108$.

Almási László - Varjú Katalin - Asztalos Tibor - Nyári Tibor - Maher, D. - Hantos Zoltán - Boda Krisztina - Bari Ferenc (2011): Informatikai eszközök az „orvosi fizika és statisztika" tantárgy oktatásában a szegedi tudományegyetem orvosképzésében; Informatika a felsőoktatásban konferencia, Debrecen

Bakó Mária (2008): Informatikai tantárgyak a pedagógusképzésben; Informatika a felsőoktatásban konferencia, Debrecen.

Baksa-Haskó Gabriella (2007): A felsőoktatásba kerülő diákok informatikai ismeretei; Tudományos Közlemények, Budapest: Általános Vállalkozási Főiskola, 17. szám, pp. 85-92. 
Baksa-Haskó Gabriella (2012): Informatika a föiskolán és a nagybetűs életben; Tudományos Közlemények, Budapest: Általános Vállalkozási Főiskola, 28. szám, pp. 41-76.

Ballér Endre (2004): A tantervelmélet útjain. Válogatás négy évtized pedagógiai írásaiból. Budapest: Aula Kiadó

Bari Ferenc - Forczek Erzsébet - Tolnai József - Peták Ferenc (2011): Kihívások és lehetőségek az orvosi-egészségügyi informatika oktatásában; Informatika a felsőoktatásban konferencia, Debrecen

Barna Róbert - Honfi Vid (2008): A pénzügy-számvitel szakos hallgatók informatikai képzése; Informatika a felsőoktatásban konferencia, Debrecen

Báthory Zoltán (2000): Tanulók, iskolák - különbségek. Egy differenciált tanításelmélet vázlata. Budapest: OKKER Oktatási Kiadó

Báthory Zoltán - Falus Iván (szerk.) (1997): Pedagógiai Lexikon. Keraban kiadó, Budapest.

Becker, W. E. (2003): Economics for a Higher Education. International Review of Economics Education, Vol. 3, No. 1, pp. 52-62.

Bloom, B. S. (szerk.) - Engelhart, M. D. - Furst, E. J. - Hill, W. H. - Krathwohl, D. R. (1956): Taxonomy of educational objectives: The classification of educational goals. Handbook 1: Cognitive domain. New York: David McKay.

Bogár Mária (2002): Tanulás mindenkinek. A tanulás fejlesztése OKI-konferencián elhangzott előadás szövege. OKI, Budapest, pp. 52-64. (http://www.ofi.hu/tudastar/tanulas-fejlesztese/tanulas-mindenkinek utolsó megtekintés: 2013. augusztus 12.)

Briggs Myers, I. - Myers, P. B. (1980): Gifts differing. Understanding Personality Type. Consulting Psychologists Press, Michigen.

Chin, K. L. - Chang, E. - Atkinson, D. (2007): Ontology-based IT Pedagogical Knowledge Framework; Proceedings of the 2007 Computer Science and IT Education Conference, http://csited.org/2007/81ChinCSITEd.pdf (utolsó megtekintés: 2013. január 31.)

Chomsky, N. (1965): Aspects of the Theory of Syntax. MA: MIT Press, Cambridge. 
Cross, K.P. (1991): Every teacher a researcher, every classroom a laboratory. The Chronicle of Higher Education, pB2.

Csapó Benő (1991): A pedagógiai pszichológia hatása a tantervekre. Pedagógiai szemle, 4. szám, 24-31. o.

Csapó Benő (2002): A tudás és a kompetenciák. A tanulás fejlesztése OKI-konferencián elhangzott elöadás szövege. OKI, Budapest. (http://www.ofi.hu/tudastar/tanulasfejlesztese/tudas-kompetenciak utolsó megtekintés: 2013. augusztus 18.)

Csernovitz Adél - Szegedi Eszter (szerk.) (2012): Munkaerőpiac-orientált felsőoktatás. Ötletek, bevált gyakorlatok az „Új készségek és munkahelyek” nevü európai kezdeményezéshez. Tempus Közalapítvány, Budapest

Dave, R. H. (1970): Developing and Writing Behavioural Objectives. Tucson, Arizona: Educational Innovators Press.

Derényi András (2006): Tanulási eredmények kidolgozása és használata. Elvi megfontolások és gyakorlati útmutatások. Társadalom és Gazdaság, 28/2., pp. 183202.

DOI: http://dx.doi.org/10.1556/tarsgazd.28.2006.2.4

DeSeCo (2005): The definition and selection of key competencies. Executive Summary.

(www.deseco.admin.ch/bfs/deseco/en/index/02.parsys.43469.downloadList.2296.Do wnloadFile.tmp/2005.dskcexecutivesummary.en.pdf letöltés: 2013. 08. 12.)

ECDL (nda): Az ECDL-röl. Neumann János Számítógép-tudományi Társaság. (http://njszt.hu/ecdl/rolunk utolsó megtekintés 2013. 08. 13.)

ECDL $\left(\mathrm{nd}_{\mathrm{b}}\right)$ : Számítógépes alapismeretek. Neumann János Számítógép-tudományi Társaság. (njszt.hu/sites/default/files/ecdl_szamitogepes_alapismeretek.pdf utolsó megtekintés 2013. 08. 18.)

ECDL (2013): Változás az ECDL rendszerben! Neumann János Számítógép-tudományi Társaság. (http://njszt.hu/ecdl/hir/20130626/valtozas-az-ecdl-rendszerben utolsó megtekintés 2013. 08. 18.)

ECDL (2009a): 1. modul - IKT alapismeretek. Neumann János Számítógép-tudományi Társaság. (http://njszt.hu/ecdl/syllabus/ikt-alapismeretek utolsó megtekintés 2013. 08. 13.) 
ECDL (2009b): 2. modul - Operációs rendszerek. Neumann János Számítógéptudományi Társaság. (http://njszt.hu/ecdl/syllabus/operacios-rendszerek utolsó megtekintés 2013. 08. 13.)

ECDL (2009c): 3. modul - Szövegszerkesztés. Neumann János Számítógép-tudományi Társaság. (http://njszt.hu/ecdl/syllabus/szovegszerkesztes utolsó megtekintés 2013. 08. 13.)

ECDL (2009d): 4. modul - Táblázatkezelés. Neumann János Számítógép-tudományi Társaság. (http://njszt.hu/ecdl/syllabus/tablazatkezeles utolsó megtekintés 2013. 08. 13.)

ECDL (2009e): 5. modul - Adatbáziskezelés. Neumann János Számítógép-tudományi Társaság. (http://njszt.hu/ecdl/syllabus/adatbazis-kezeles utolsó megtekintés 2013. 08. 13.)

ECDL (2009f): 6. modul - Prezentáció. Neumann János Számítógép-tudományi Társaság. (http://njszt.hu/ecdl/syllabus/prezentacio utolsó megtekintés 2013. 08. 13.)

ECDL (2009g): 7. modul - Internet és kommunikáció. Neumann János Számítógéptudományi Társaság. (http://njszt.hu/ecdl/syllabus/internet-es-kommunikacio utolsó megtekintés 2013. 08. 13.)

ECDL (2013): Változás az ECDL rendszerben!. Neumann János Számítógép-tudományi Társaság. (http://njszt.hu/ecdl/hir/20130626/valtozas-az-ecdl-rendszerbenutolsó megtekintés 2013. 08. 13.)

Edupress (2013): Alakulóban a hazai képesítési keretrendszer. (http://www.edupress.hu/hirek/index.php?pid=egycikk\&HirID=28904 utolsó megtekintés: 2013. 08. 28.)

Engwall, L. (2007): The anatomy of management education. Scandinavian Journal of Management, 23. 4-35. o.

DOI: http://dx.doi.org/10.1016/j.scaman.2006.12.003

Erikson, S. C. (1984): The essence of good teaching: helping students learn and remember what they learn. San Francisco, CA: Jossey-Bass.

Érettségi vizsgakövetelmények (2002): 40/2002. (V. 24.) OM rendelet az érettségi vizsga részletes követelményeiről. Informatika melléklet 
European Commission (2002): Key Competencies. A Developing Concept in General Compulsory Education. The Information Network on Education in Europe. Eurydice, European Unit. Brussels.

European Commission (2009a): ECTS Users' Guide. Luxembourg: Office for Official Publications of the European Communities.

(http://ec.europa.eu/education/tools/docs/ects-guide_en.pdf utolsó megtekintés: 2014. 07. 18.)

European Commission (2009b): Bologna beyond 2010. Report on the development of the European Higher Education Area. Background paper for the Bologna Follow-up Group prepared by the Benelux Bologna Secretariat. Leuven/Louvain-la-Neuve Ministerial Conference

European Commission (2010): A bizottság közleménye. EURÓPA 2020. Az intelligens, fenntartható és inkluzív növekedés stratégiája. Brüsszel.

European Commission (2012): The European Higher Education Area in 2012: Bologna Process Implementation Report. Education, Audiovisual and Culture Executive Agency.

(http://www.ehea.info/Uploads/\%281\%29/Bologna\%20Process\%20Implementation \%20Report.pdf utolsó megtekintés: 2014. 07. 18.)

European Higher Education Area (1999): The Bologna Declaration of 19 June 1999. Joint declaration of the European Ministers of Education. (www.ehea.info/Uploads/Declarations/BOLOGNA_DECLARATION1.pdf letöltve 2013. 08. 07.)

European Higher Education Area (2001): TOWARDS THE EUROPEAN HIGHER EDUCATION AREA Communiqué of the meeting of European Ministers in charge of Higher Education in Prague on May 19th 2001.

(www.ehea.info/Uploads/Declarations/PRAGUE_COMMUNIQUE.pdfletöltve 2013. 08. 07.)

European Higher Education Area (2003): Realising the European Higher Education Area. Communiqué of the Conference of Ministers responsible for Higher Education in Berlin on 19 September 2003.

(www.ehea.info/Uploads/Declarations/Berlin_Communique1.pdfletöltve 2013. 08. 07.) 
European Higher Education Area (2010): Budapest-Vienna Declaration on the European Higher Education Area (www.ehea.info/Uploads/Declarations/Budapest-Vienna_Declaration.pdf letöltve 2013. 08. 07.)

European Higher Education Area (2012a): Making the Most of Our Potential:

Consolidating the European Higher Education Area. Bucharest Communiqué.

FINAL VERSION

(http://www.ehea.info/Uploads/\%281\%29/Bucharest $\% 20$ Communique\%202012\%28 1\%29.pdf letöltve 2013. 08. 07.)

European Higher Education Area (2012b): Bologna Process Implementation Report. (http://www.ehea.info/uploads/\%281\%29/bologna\%20process $\% 20$ implementation $\%$ 20report.pdf letöltve 2013. 08. 23.)

European Union (2006): Recommendation of The European Parliament and of the Council of 18 December 2006 on key competences for lifelong learning.2006/962/EC [Official Journal L 394 of 30.12.2006]

European Universities Association EUA (2007): Trends V - Universities Shaping the European higher Educations Area, EUA Publications.

(http://www.eua.be/fileadmin/user_upload/files/Publications/Final_Trends_Report May_10.pdf)

Eurydice (2002): Key Competencies A developing concept in general compulsory education. http://bookshop.europa.eu/en/key-competencies-pbEC3212295/ (utolsó megtekintés: 2014. július 13.)

Eurydice (2005): Eurybase The Information Database on Education Systems in Europe: The Education System in Hungary 2004/5. http://www.ond.vlaanderen.be/hogeronderwijs/bologna/links/language/EurydiceHungary.pdf (letöltve: 2010. április 20.)

Falus Iván (2006): A kompetencia fogalma és a kompetencia alapú képzés tervezése. Társadalom és gazdaság 28. pp. 173-182 DOI: http://dx.doi.org/10.1556/tarsgazd.28.2006.2.3 
Fernández-López, M. (szerk.): OntoWeb (2002): A survey on methodologies for developing, maintaining, evaluating and reengineering ontologies. OntoWeb Technical Report, 2002;http://www.york-sure.de/publications/OntoWeb_Del_1-4.pdf (letöltve: 2010. április 20.)

Ferris, T. L. J. - Aziz, S. M. (2005): A Psychomotor Skills Extension to Bloom's Taxonomy of Education Objectives for Engineering Education. Exploring Innovation in Education and Research, March 2005.

Fischer Andrea - Halász Gábor (2009): Tanulási eredmények alkalmazása a felsőoktatási intézményekben. Bologna füzetek 2. Tempus Közalapítvány, Budapest

Füstös L. - Kovács E. - Meszéna Gy. - Simonné Mosolygó N. (2004): Alakfelismerés. (Sokváltozós statisztikai módszerek) Budapest, Új Mandátum Kiadó.

González, J. - Wagenaar, R. (szerk.) (2008): Universities' contribution to the Bologna Process. An introduciton. European Commision, Tuning project. 2nd ed.

Hansen, W. L. (2001): Expected Proficiencies for Undergraduate Economics Majors. Journal of Economic Education, Vol. 32, No. 3, pp. 231-242.

DOI: http://dx.doi.org/10.2307/1183381

Honfi Vid - Neuhoffer Hajnalka - Barna Róbert (2008): Szükséges-e a számítógépes bünözés oktatása pénzügy szakon? Informatika a felsőoktatásban konferencia, Debrecen

Kánnai Zoltán - Pintér Miklós - Tasnádi Attila (2010): Matematikaoktatás a bolognai típusú gazdasági képzésekben. Közgazdasági Szemle, LVII. évf., 2010. március (pp. 261-277. )

Kennedy, D. (2007): Tanulási eredmények megfogalmazása és azok használata. Gyakorlati útmutató. University College, Cork.(http://oktataskepzes.tka.hu/download.php?doc name=docs/tanulasi\%20eredm enyek\%20elismerese/lo_handbook_declan_kennedy.pdf utolsó megtekintés: 2014. 07. 18.)

Kolb, D.A. (1984): Experiential Learning: Experience as a source of Learning and Development. Englewood Cliffs, N.J.: Prentice Hall. 
Krathwohl, D. R. (2002): A Revision of Bloom's Taxonomy: An Overview.Theory into practice. Autumn. 212-218. o.

DOI: $\underline{\text { http://dx.doi.org/10.1207/s15430421tip4104_2 }}$

Kron, F. W. (2000): Pedagógia. Osiris Kiadó, Budapest

Kruzslicz Ferenc (2014): Képzési és kimeneti követlemények elemzése duo-mining eszközökkel. Gikof Journal 2014/1. (pp. 14-27.) Neumann János Számítógéptudományi Társaság, Budapest.

(http://gikof.njszt.hu/gikof/GIKOF_JOURNAL_2014-1.pdf, letöltve: 2014. július 13.)

Mager, R. (1962): Preparing Instructional Objectives, revised 2nd edn., Belmont, CA, David Lake Publishers.

Mantas, J. - Ammenwerth, E. - Demiris, G. - Hasman, A. - Haux, R. - Hersh, W. Hovenga, E. - Lun, K. C. - Marin, H. - Martin-Sanchez, F. - Wright, G. (2011): Recommendations of the International Medical Informatics Association (IMIA) on Education in Biomedical and Health Informatics - First Revision; European Journal for Biomedical Informatics, vol. 7., 3-18. o.

Meyers, C. - Jones, T. B. (1993): Promoting Active Learning: Strategies for the college classroom. San Francisco, CA: Jossey-Bass.

DOI: $\underline{\text { http://dx.doi.org/10.1016/0307-4412(94)90198-8 }}$

Mihályi Ildikó (2002): OECD-szakértők a kulcskompetenciákról. Új Pedagógiai Szemle. 2002/6. pp. 90-99.

Mihályi Ildikó (2003): Mégy egyszer a kulcskompetenciákról. Új Pedagógiai Szemle. 2003/6. pp. 103-112.

Ministry of Science, Technology and Innovation (2005): A Framework for Qualifications of the European Higher Education Area Bologna Working Group on Qualifications Frameworks. Bologna Working Group on Qualifications Frameworks, Copenhagen.

MTA (1992): Magyar Értelmező Kéziszótár. Akadémiai Kiadó.

Nemzeti alaptanterv (1995): 130/1995. (X. 26.) Korm. rendelet a Nemzeti alaptanterv kiadásáról. 
Nemzeti alaptanterv (2003): 243/2003. (XII. 17.) Korm. rendelet a Nemzeti alaptanterv kiadásáról, bevezetéséről és alkalmazásáról.

Nemzeti alaptanterv (2007): 202/2007. (VII. 17.) Korm. rendelet a Nemzeti alaptanterv kiadásáról, bevezetéséről és alkalmazásáról szóló 243/2003. (XII. 17.) Korm. rendelet módosításáról.

Nemzeti alaptanterv (2012): 110/2012. (VI. 4.) Korm. rendelet a Nemzeti alaptanterv kiadásáról, bevezetéséről és alkalmazásáról.

Nemzeti Erőforrás Minisztériuma (nd): Gazdaságtudományok képzési terület. in: Alapképzési és hitéleti szakok jegyzéke. pp. 123-140 (http://www.nefmi.gov.hu/felsooktatas/kepzesi-rendszer/alapkepzesi-szakok-kkk utolsó megtekintés: 2013.08. 30.)

OECD (2011): Tuning-AHELO Conceptual Framework of Expected and Desired Learning Outcomes in Economics. OECD Education Working Papers, No. 59, OECD Publishing. (http://dx.doi.org/10.1787/5kghtchwb3nn-en, letöltve: 2013. augusztus 20.)

Perjés István - Vass Vilmos (szerk.) (2009): A kompetenciák tantervesítése: A tartalmi szabályozás meghatározó elemei, a tantervi paradigmák komparatisztikája. Budapest: Budapesti Corvinus Egyetem

Ranschburg Ágnes (2004): Az iskolák értékelési-mérési gyakorlata és a kompetenciák. Új Pedagógiai Szemle, 2004/3 pp. 52-68. (http://www.ofi.hu/tudastar/iskolak-ertekelesi)

Sós Katalin - Nánai László (2011): Physics is high education for non physicists. Kitekintés - Perspective; Békéscsaba: Szent István Egyetem, Különszám, pp. 183-188.

Spencer, L. M. (1997): Competency Assessment Methods. in Bassi, L. J. - Russ-Eft, D (szerk.): Assessment, Development, and Measurement. pp. 1-36.American Society for Training \& Development. (http://www.google.hu/books?id=g8_yKiqe6JwC\&printsec $=$ frontcover\&hl $=h \mathrm{hu} \# \mathrm{v}=\mathrm{on}$ epage $\& q \& \mathrm{f}=$ false)

Staab, S. - Studer, R. - Schnurr, H. P. - Sure, Y. (2001): Knowledge Process and Ontologies, IEEE Intelligent Systems Vol. 16, No. 1, pp. 26-34. 
Szabó G. Ferenc (2010): A kommunikatív kompetencia. Anyanyelv-pedagógia 2010/2. Magyar Nyelvtudományi Társaság Magyartanári Tagozat.

Szebenyi Péter (1994): Tantervkészítés egykor és most. Educatio, ősz, 345-354. o.

SZIE (2001): Az európai gyakorlathoz illeszkedő munkaerőpiaci készségigény felmérése a magyar oktatás-képzés fejlesztése szolgálatában. Szent István Egyetem Gazdaság- és Társadalomtudományi Kar Vezetéstudományi Tanszék.

Tikk Domonkos (szerk.) (2007): Szövegbányászat, TypoTeX, Budapest.

Tuning Project (2009): Reference Points for the Design and Delivery of Degree Programmes in Business. European Commission: Tuning Project. (http://www.unideusto.org/tuningeu/images/stories/Publications/Business_final_versi on.pdf utolsó megtekintés: 2014. 07. 18.)

Tyler, R. (1949): Basic Priciples of Curriculum and Instruction. The University of Chicago Press, Chicago DOI: http://dx.doi.org/10.7208/chicago/9780226820323.001.0001

Vámos Ágnes (2010): Tanulási eredmények alkalmazása a felsőoktatási intézményekben 2. Bologna füzetek 6. Tempus Közalapítvány, Budapest

Vámost Ágnes (2013): A kompetencia. OH 413 projekt. (http://www.413.hu/files/A kompetencia 201304 10.pdf, utolsó megtekintés: 2014. 07. 18.)

Varga Katalin (1991): Tantervi reformtörekvések a nagyvilágban. Új Pedagógiai Szemle, 6., 79-83. o.

Vas Réka Franciska (2007): Tudásfelmérést támogató oktatási ontológia szerepe és alkalmazási lehetőségei; PhD disszertáció. Budapest: Budapesti Corvinus Egyetem

Vass Vilmos (2006): A kompetencia fogalmának értelmezése. In Kerber Zoltán (szerk.): Hidak a tantárgyak között. Országos Közoktatási Intézet, Budapest. (http://www.ofi.hu/tudastar/hidak-tantargyak-kozott/kompetencia-fogalmanak)

Vig Zoltán (2005): Internetes attitüdvizsgálatok a felsőoktatásban In: Megújuló szakképzés - szemelvények diplomamunkákból, BME MPT, pp. 153-183.

Vig Zoltán (2008): A felsőoktatásban tanulók internet használatának és attitűdjének vizsgálata; PhD disszertáció. Budapest: Budapesti Müszaki Egyetem 


\section{A TÉMAKÖRREL KAPCSOLATOS SAJÁT (ÉS TÁRS- SZERZŐS) PUBLIKÁCIÓK JEGYZÉKE}

\section{Referált szakmai folyóirat:}

Baksa-Haskó Gabriella (2014): A közgazdász hallgatók informatikai előismeretei. Vezetéstudomány (megjelenés alatt)

Baksa-Haskó Gabriella (2012): Számítógép használat gazdálkodástani végzettséggel a munkahelyen. Educatio 21:(4) pp. 638-646.

\section{Egyéb folyóirat:}

Baksa-Haskó Gabriella (2014): Informatikaoktatás a gazdasági felsőoktatásban. GIKOF Journal (megjelenés alatt)

Baksa-Haskó Gabriella (2012): Informatika a föiskolán és a nagybetűs életben. Tudományos Közlemények. Általános Vállalkozási Főiskola (28) pp. 41-76.

Baksa-Haskó Gabriella (2011): Informatikaoktatás a gazdálkodástudományi felsőoktatásban. Perspective : Revista de Stiinta si Cultura 15: (Különszám) pp. 130138.

Baksa-Haskó Gabriella (2010): Gondolatok az informatikaoktatásról. Tudományos Közlemények. Általános Vállalkozási Főiskola (24) pp. 85-90.

Baksa-Haskó Gabriella (2007): A felsőoktatásba kerülő diákok informatikai ismeretei. Tudományos Közlemények. Általános Vállalkozási Főiskola (17) pp. 85-92.

\section{Tankönyvek, jegyzetek:}

Baksa-Haskó Gabriella (2011): Szövegszerkesztés: Jegyzet a Gazdaságinformatikai alapismeretek tantárgyhoz és szakdolgozat-írási segédlet. Budapest: Általános Vállalkozási Főiskola, 2011.92 p.

Quittner Pál, Baksa-Haskó Gabriella (2007): Adatbázisok, adatbázis-kezelő rendszerek [elektronikus dok.]. Debrecen: DE ATMC AVK, 2007. 328 p. (ISBN:978-963-973266-7) 
Baksa-Haskó Gabriella (2007): Irodai alkalmazások: hosszú dokumentumok szerkesztése. In: Cser László, Németh Zoltán (szerk.): Gazdaságinformatikai alapok: [Programozási alapok, adatbázisok, számítógép-hálózatok]. 209 p. Budapest: Aula Kiadó , 2007. pp. 145-161. (Bologna tankönyvsorozat) (ISBN:978 963969820 8)

Lévayné Lakner Mária, Baksa-Haskó Gabriella (2006): Excel 2003 táblázatkezelés és programozás a gyakorlatban 120 feladattal. Budapest: ComputerBooks, 2006. 214 p. (ISBN:963 618344 9)

\section{Konferencia előadások:}

Baksa-Haskó Gabriella (2012): Hozott anyagból - a főiskolát 2012-ben kezdők informatikai előismeretei. A Magyar Tudomány Napja az Általános Vállalkozási Főiskolán. 2012, Budapest. (http://avf.hu/mtu2012/?download=MTU2012fuzet.pdf)

Baksa-Haskó Gabriella (2010): A felsőoktatás tartalmának és a munkaerőpiaci igényeknek a folyamatos összehangolása a web 2.0 korszakában. Matematikát, fizikát és informatikát oktatók XXXIV. konferenciája. 2010, Békéscsaba (http://gfk.tsf.hu/mafiok2010/attachments/004 PROGRAMFUZET.pdf)

Baksa-Haskó Gabriella (2010): Informatikaoktatás a gazdálkodástudományi felsőoktatásban. A Magyar Tudomány Napja az Általános Vállalkozási Főiskolán. 2010, Budapest. (http://avf.hu/mtu2010/?download=MTUonline.pdf)

Baksa-Haskó Gabriella (2006): A felsőoktatásba kerülő diákok informatikai ismeretei. A Magyar Tudomány Napja az Általános Vállalkozási Főiskolán. 2006, Budapest.

Dancsó Tünde - Baksa-Haskó Gabriella (2006): A felsőoktatási intézmények hallgatóinak informatikai kompetenciái. PÉK 2006, IV. Pedagógiai Értékelési Konferencia. 2006, Szeged.

(http://www.edu.u-szeged.hu/pek2006/download/PEK_2006_Konferenciakotet.pdf) 